\author{
LATVIJAS UNIVERSITĀTE \\ Humanitāro zinātṇu fakultāte \\ Baltu valodniecības katedra \\ UNIVERSITY OF LATVIA \\ Faculty of Humanities \\ Baltic Linguistics
}

\title{
BALTU FILOLOG̦IJA
}

\section{XXIX (1) 2020}

Baltu valodniecības žurnāls

Journal of Baltic Linguistics 


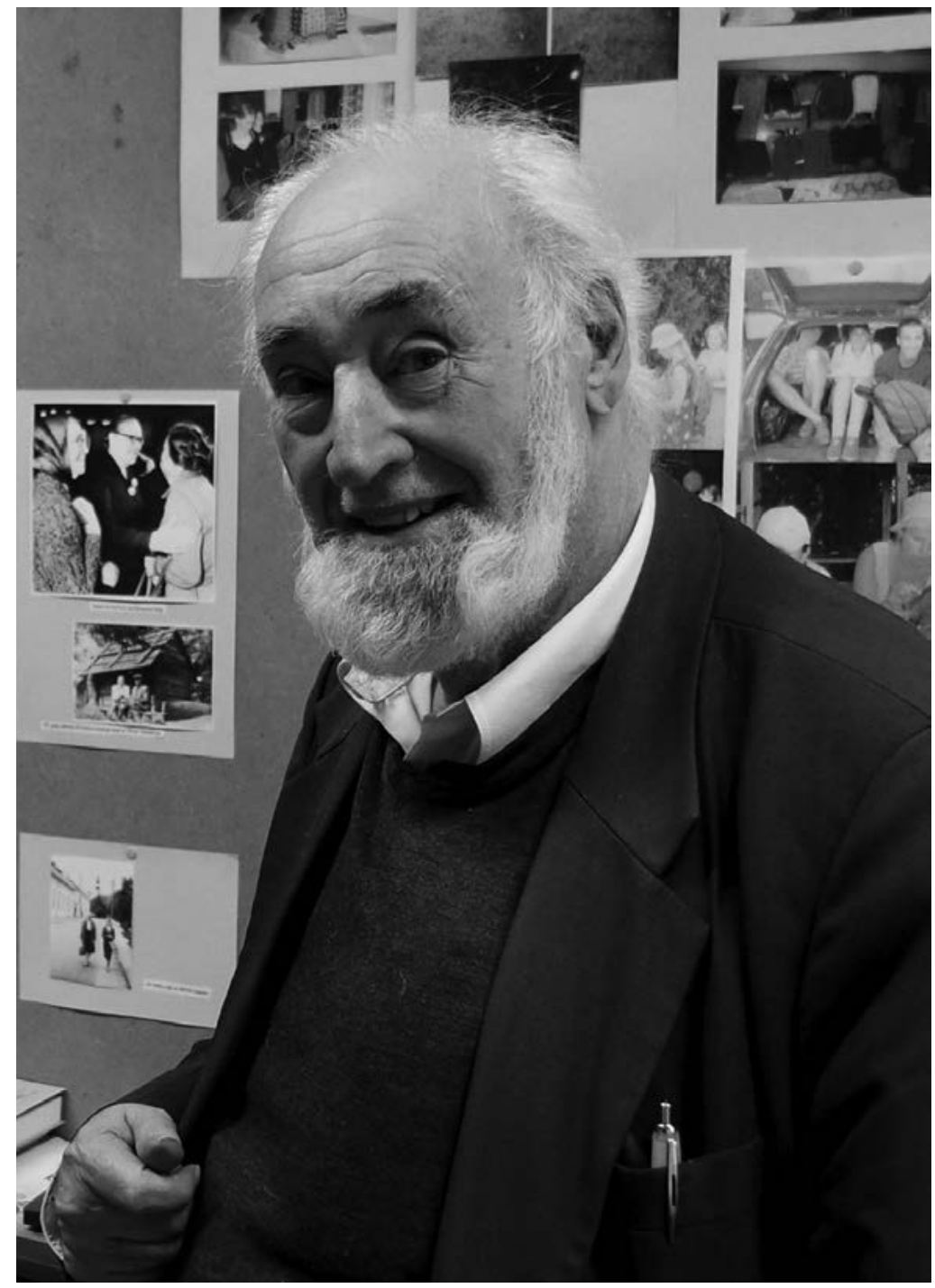




\title{
Veltijums \\ profesoram Trevoram G. Fennelam astoṇdesmitajā dzimšanas dienā
}

\author{
A Festschrift \\ to Professor Trevor G. Fennell \\ on the occasion of his eightieth birthday
}


UDK 811(082)(051)

Ba 418

\section{BALTU FILOLOG̣IJA}

Redaktors / Editor

Pēteris Vanags

Latvijas Universitāte, Stockholms universitet

Redaktora vietnieki / Associate Editors

Lidija Leikuma

Latvijas Universitāte
Edmundas Trumpa

Latvijas Universitāte

Redakcijas kolēgija / Editorial Board

Aleksej Andronov
Sankt-Peterburgskij gosudarstvennyj
Laimute Balode
Latvijas Universitāte,
Helsingin yliopisto
Rick Derksen
Leiden
Pietro U. Dini
Università degli Studi di Pisa
Trevor G. Fennell
Flinders University of South Australia
Artūras Judžentis
Vilniaus dailès akademija
Jenny Larsson
Stockholms universitet
Benita Laumane
Liepäjas Universitäte

Dace Markus

Liepājas Universitāte

Nicole Nau

Universytet im. Adama Mickiewicza w Poznaniu

Juozas Pabrèža

Šiaulių universitetas

Jurgis Pakerys

Vilniaus universitetas

Bonifacas Stundžia

Vilniaus universitetas

Giedrius Subačius

University of Illinois at Chicago

Jānis Valdmanis

Latvijas Universitāte

Steven Young

University of Maryland,

Baltimore County

Baltu filologiija ir recenzējams izdevums ar starptautisku redakcijas kolēǵiju. Visus iesniegtos rakstus pirms to publicēšanas recenzenti novērtē un akceptē.

Baltu filologija is a fully refereed journal with an international panel of referees. All articles submitted are assessed by our referees before being accepted for publication.

Sējuma valodas konsultanti: Anna Frīdenberga (latviešu valoda), Steven Young (angḷu valoda), Edmundas Trumpa (lietuviešu valoda), Frederik Bissinger (vācu valoda).

Language consultants for this volume: Anna Frīdenberga (Latvian), Steven Young (English), Edmundas Trumpa (Lithuanian), Frederik Bissinger (German).

Redakcijas adrese / Editorial Address

Baltu valodniecības katedra

(c) Latvijas Universitāte, 2020

Humanitāro zinātṇu fakultāte

Latvijas Universitāte

Visvalža iela $4 \mathrm{~A}$

Rīga, LV-1050, Latvija

e-pasts: pvanags@latnet.lv 


\section{SATURS - CONTENTS}

Trevoram Gārtam Fennelam $-80 \ldots \ldots \ldots \ldots \ldots \ldots$

\section{Raksti - Articles}

Rainer ECKERT

Zur Baltistik in Schweden um die Mitte der siebziger Jahre

des vergangenen Jahrhunderts $\ldots \ldots \ldots \ldots \ldots \ldots \ldots \ldots$

Anna FRĪDENBERGA

Reduplikācija Georga Manceḷa Sprediḳu grāmatā (1654) . . . . . . . 19

Aurelija GRITÉNIENE்

Rusija „Lietuvių kalbos žodyno“ iliustraciniuose sakiniuose ir

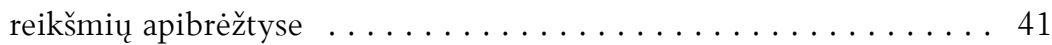

Māra GRUDULE

Mihala Jana Borha dzejojums „Varakḹanu pils jūtu dārzs“

(Jardin sentimental du château de Warakland, 1795)

apgaismības literatūras kontekstā ................ 63

Ilga JANSONE

Stārķis (vācu Storch) latviešu valodas leksikogrāfiskajos avotos . . . 73

Dzintra PAEGLE, Pēteris VANAGS

Mālpils draudzes mācītāja Oto Roberta fon Klota (1808-1876)

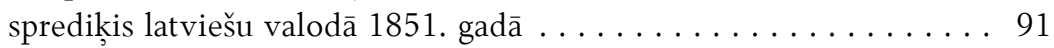

Alma RAGAUSKAITÉ

Krikščioniškos kilmès asmenvardžiai Lietuvoje seniausioje 1599-1621 m. Joniškio parapijos krikšto metrikų knygoje .. . . . 115

Ërika SAUSVERDE

A Case of Teaching Modern Latvian $\ldots \ldots \ldots \ldots \ldots \ldots \ldots$ 
Renāte SILIN̦A-PIN̦ĶE

Latviešu personvārdi ar -it un -ull 17. gadsimtā . . . . . . . . . . 141

Anta TRUMPA

Blèdis, blēel̄gs, blēdnieks un liekulis latviešu valodas senajos tekstos: nozīmes pārmaiņa? . . . . . . . . . . . . . . . . . . . . 149

Izdošanas principi - Publication Policy $\ldots \ldots \ldots \ldots \ldots 3$ 


\section{TREVORAM GĀRTAM FENNELAM -80}

2020. gada 16. jūlijā savu astoņdesmito gadskārtu atzīmēja profesors Trevors Gārts Fennels ( Trevor Garth Fennell) - ievērojamais latviešu valodas un tās vēstures pētnieks, ilggadējs Dienvidaustrālijas Flindersa Universitātes (Flinders University of South Australia) profesors. Viņš ir plaši pazīstams un cienīts savu kolēğu vidū gan Latvijā, gan citviet pasaulē. Profesora lielākais ieguldījums saistāms ar 17. un 18. gadsimta latviešu valodniecības darbu izpēti, kā arī to kritisku izdevumu sagatavošanu.

Profesors Trevors Fennels dzimis 1940. gada 16. jūlijā Portaugustā (Port Augusta) Dienvidaustrālijas pavalstī. Turpmākā viņa pamata dzīves vieta ir bijusi nemainīga - Adelaides (Adelaide) pilsēta, kur viņš gājis skolā, 1957. gadā beidzis vidusskolu, 1958.-1961. gadā studējis franču valodu un literatūru Adelaides Universitātē (University of Adelaide). Tad ar šīs universitātes stipendiju devies uz Franciju, lai rakstītu doktora disertāciju. Darbs La Morphologie du Futur en Moyen Français aizstāvēts 1965. gadā Parīzē, bet izdots 1975. gadā Šveicē. Kopš 1966. gada līdz pat emeritūrai Trevors Fennels strādājis par franču valodas mācībspēku jaunizveidotajā Dienvidaustrālijas Flindersa Universitātē Adelaidē. Vispirms viņš bija lektors, tad no 1970. gada vecākais lektors, no 1975. gada docents (Reader), bet kopš 1994. gada - profesors, sākotnēji ar personālu profesūru. Būdams franču valodas mācībspēks, viņš tomēr pētnieciskā laukā galveno vērību pievērsis latviešu valodas un tās vēstures izpētei.

Saskarē ar latviešiem Trevors Fennels nonāca 1956. gadā, kad vēl gāja vidusskolā. Viņa klasē mācījās divi latviešu puiši, pēc tam viņš iepazinās vēl arī ar citiem latviešiem. Tad arī radās pirmā interese par latviešu valodu, ko iemācīties cittautietim esot gandrīz vai neiespējami, kā teikuši viņa draugi. 1959. gadā Trevors satikās ar vēl vienu interesantu personību - Henriku Gelsenu (Henrik Gelsen), vācieti no Latvijas, kuram bija lemts ḳ̣ūt par viņa galveno latviešu valodas skolotāju un kolēgei. Līdztekus doktora studijām Parīzē 1965. gadā aizsākās abu kopdarbs pie latviešu valodas gramatikas. Šì nodarbe dažādu apstākḷlu dēḷ prasīja ilgāku laiku, taču vainagojās ar latviešu valodas mācības grāmatu trīs sējumos, kas vienlaikus ir arī gramatika A Grammar of Modern Latvian (1980). Tajā gandrīz divos tūkstošos lappušu un 244 stundās ir izskaidrota visa latviešu valodas gramatika, kas papildināta ar plašiem vingrinājumiem, kuros netrūkst arī humora, kas tik raksturīgs abiem autoriem. 
Līdztekus gramatikas rakstīšanai Trevors Fennels pievērsās problēmām, kas saistītas ar sinhronu latviešu valodas izpratni, ar jautājumiem, kas nodarbina gan tos, kas latviešu valodu māca, gan tos, kas to mācās. Viņš rakstīịis par piedēkli -nieks, par šauro un plato $e$, par noteikto adjektīvu, atgriezenisko lietvārdu un darbības vārdu atvasināšanu, par pirmās konjugācijas verbu klasifikāciju, par piederības konstrukciju sintaksi, par subjektu debitīva konstrukcijās un instrumentāla problemātiku, izvērsdams argumentāciju pret šì locījuma postulēšanas nepieciešamību sinhronā latviešu valodas gramatikā.

Nākamajos gados Trevors Fennels pievērsās latviešu valodas apraksta vēstures izpētei, sākot ar pirmajām gramatikām, kas pētniekiem tai laikā bija grūti pieejamas. Tāpēc arī radusies doma tās ne tikvien pètīt, bet arī par jaunu izdot. Kā pirmā 1982. gadā izdota grāmata The First Latvian Grammar, kurā iekḷauta Johana Georga Rēhehūzena gramatika (1644). Tai pašā gadā publicēta arī Seventeenth-Century Latvian Grammatical Fragments ar Paula Einhorna un Georga Bihnera manuskriptiem. 1984. gadā iznāca Georg Dreszell's Gantz Kurtze Anleitung Zur Lettischen Sprache. Text. Translation. Commentary. Concordance ar Georga Dresel̦a gramatiku (1685), 1987. gadā The Grammatical Appendix to Johannes Langius' Latvian-German Lexicon ar Johana Langija gramatikas manuskriptu (1685), bet 1993. gadā - arī Heinriha Ādolfija gramatikas (1685) jaunizdevums Adolphi’s Latvian Grammar.

Šajos izdevumos, izņemot pēdējo, iekḷauta arī sīka tekstu un to rašanās analīze, agrāk publicēto citu pētnieku rakstu kopijas, kā arī avotu latviešu valodas vārdu rādītāii. Vairākus rādītājus Trevors Fennels sagatavojis arī citiem izdevumiem: Georga Manceḷa vārdnīcas Lettus abām dạāām - A LatvianGerman Revision of G. Mancelius” „Lettus“(1638) (1988) un A Latvian-German Revision of G. Mancelius' „Phraseologia Lettica“ (1638) (1989), kā arī Johana Langija vārdnīcas manuskriptam An Alphabetical Re-organization of Johannes Langius” „Lettisch-Deutsches Lexicon“ (1685) (1991).

Šajos gados Trevors Fennels publicējis arī daudzus rakstus periodikā par 17. gadsimta latviešu valodniecības darbiem. Publikācijās aplūkotas tādas problēmas kā, piemēram, verbi Rēhehūzena gramatikā, nomenu morfoloǵijas apraksta pirmsākumi un attīstība, verbu apraksta problemātika, atsevišku gramatiku problemātika, kā arī citi jautājumi. 1995. gadā izdots viņa agrīno rakstu kopkrājums Lingua Lettica, kur angliski sarakstītie darbi tulkoti latviešu valodā.

Pēc pirmo latviešu gramatiku izdošanas Trevors Fennels atrada sev jaunu izaicinājumu - 17. gadsimta latviešu leksikogrāfiskos manuskriptus, kas glabājas Latvijas Akadēmiskajā bibliotēkā. Vispirms profesors sagatavoja 
Kristofora Fīrekera vārdnīcas manuskriptu izdevumus Fürecker's Dictionary: the First Manuscript (1997) un Fürecker's Dictionary: the Second Manuscript (1998). 2001. gadā izdota arī anonīmā vārdnīca Manuale Lettico-Germanicum. Turklāt 2000. gadā divos sējumos publicēts arī visu trīs manuskriptu apvienots latviešu vārdu rādītājs Fürecker's Dictionary: a Concordance, bet 2003. gadā arī atseviškss rādītājs $A$ Concordance to the „Manuale Lettico-Germanicum“. Līdztekus tekstu izdošanai profesors ir nodarbojies arī ar to izpēti, lasīdams referātus daudzās konferencēs, kā arī publicēdams rakstus par agrīno vārdnīcu satura un autorības problemātiku.

Pabeidzis ieplānotos darbus pie 17. gadsimta vārdnīcām, Trevors Fennels ķēries pie nākamā perioda, kuru ievada plašais Liborija Depkina vārdnīcu manuskriptu klāsts. Astoņu gadu laikā (2005-2012) publicēti septinị sējumi Liborius Depkin. Lettisches Wörterbuch, kuros ieklauti visi Depkina vārdnīcu rokraksti. Pēc to izdošanas profesors aizsācis latviešu vārdu rādītāja gatavošanu. Oriǵināla lielā apjoma dēl rādītājam vajadzētu daudz vairāk nekā astoņus sējumus, tāpēc domājams, ka tie būs pieejami elektroniskā formātā. Tomēr līdz rezultātam vēl ejams visai garš ceḷšs.

Profesors vienmēr bijis ne tikai aktīvs pētnieks, bet arī nepārtraukti iesaistīịies administratīvā un organizatoriskā darbā. Viņa veikums latviešu valodas pētniecībā ir arī augstu novērtēts. 1990. gadā Trevors Fennels ievēlēts par Latvijas Zinātṇu akadēmijas ārzemju locekli, 1996. gadā saņēmis Jāņa Endzelīna vārdbalvu, 2001. gadā - Triju Zvaigžņu ordeņa IV šķiru (pieškirts 1999), 2006. gadā - Latvijas Zinātņu akadēmijas Lielo medaḷu, bet 2018. gadā ievēlēts par Latvijas Universitātes Goda doktoru.

Šis žurnāla „Baltu filolog̣ija“ sējums arī ir cieņas apliecinājums profesora devumam latviešu valodniecībā un reizē sveiciens no kolẹgiem viņa astoņdesmitajā dzimšanas dienā. Vēlēsim mūsu visu cienītajam profesoram Trevoram Fennelam labu veselību un darbaprieku, kā arī gaidīsim viṇu atkal Latvijā!

Kolēgu vārdā

„Baltu filologiijas“ redakcija 



\title{
ZUR BALTISTIK IN SCHWEDEN UM DIE MITTE DER SIEBZIGER JAHRE DES VERGANGENEN JAHRHUNDERTS
}

\author{
Rainer ECKERT \\ Berlin
}

\section{Vorbemerkung}

Ich widme diesen Vortrag meinem lieben Kollegen Prof. Dr. Trevor Fennell zum 80. Geburtstag und sende ihm herzliche Grüße und alle guten Wünsche. Wir haben uns auf vielen internationalen Konferenzen zur Baltistik in Schweden, in Deutschland, in den baltischen Staaten und ziemlich regelmäßig auf den internationalen Kongressen der AABS von 1992 bis 2006 in Nordamerika getroffen und pflegten einen herzlichen und regen Austausch. Besonders gern erinnere ich mich an unsere gemeinsame Busfahrt von Indianapolis nach Bloomington am 18. Juni 1989 zur 16. AABS-Konferenz „Baltische Probleme in internationalen Perspektiven“ vom 19. bis 21. 06. 1989 an der Indiana University Bloomington. ${ }^{1}$

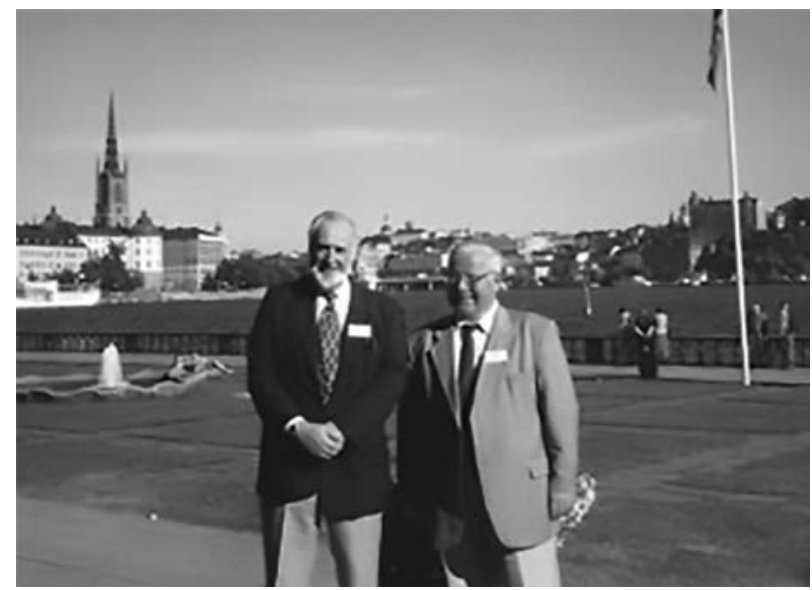

$A b b$. 1. Prof. Dr. Trevor Fennell (links) mit dem Autor in Stockholm vor dem Rathaus am Mälarsee, 1989

1 Rainer Eckert. Die 20. Konferenz der AABS in Washington 2006 (Bericht mit anschließender Zusammenfassung meiner Kongressreisen nach Amerika), in: Baltu filolog̣ija XV (1/2) Rīga 2006, 159. 
Lieber Trevor, ich möchte Sie meines tiefsten Dankes für die vielen wertvollen Buchgeschenke zur Geschichte des Lettischen und vor allem zur historischen Lexikographie dieser Sprache versichern und gleichzeitig bekunden, dass ich die faszinierenden und gehaltvollen Gespräche mit Ihnen in freudiger Erinnerung bewahre.

Ausgangspunkt für den vorliegenden Beitrag war eine freundliche Einladung der Leiterin des Baltistischen Bereiches des Instituts für slawische und baltische Sprachen (Institutionen för slaviska och baltiska språk) der Universität Stockholm Frau Prof. Dr. Velta Rūkse-Dravina zu Vorlesungen über slawische Phraseologie und zur 4. Konferenz über Baltistik in Schweden mit einem Studienaufenthalt in Stockholm vom 04. bis 11. Oktober 1976. Meine Eindrücke über die schwedische Baltistik unter Auswertung des Artikels von Frau Prof. V. Rūķe-Draviņa „Lettisk och litauisk språkforskning“ (,Lettische und litauische Sprachforschung ") regten mich an, einen Vortrag im Berliner Baltistenkreis $^{2}$ zu halten, der leider damals nicht veröffentlicht wurde, da wir kein Publikationsorgan für unsere wissenschaftliche Gesellschaft besaßen.

\section{Zu einigen markanten Zügen der schwedischen Baltistik}

Die schwedische Baltistik nimmt eine beachtete Stellung innerhalb der Baltistik der skandinavischen Länder ein und lässt eine wachsende Bedeutung für die internationale Entwicklung dieses sprachwissenschaftlichen Zweiges erkennen. So finden seit Beginn der siebziger Jahre in einem Zweijahresrhythmus Symposien zur Baltistik an der Universität Stockholm statt. Die erste Konferenz dieser Art fand im Jahre 1971 statt als Symposium om balterna i Sverige. Föredrag hållna vid symposiet den 4-5 juni 1971 i Stockholm på Hässelby slott. Es folgte das zweite Symposium als Second Conference on Baltic Studies in Scandinavia 1973, das dritte Symposium als The Third Conference on Baltic Studies in Stockholm 1975 und das vierte Symposium als The Fourth Conference of Baltic Studies in Scandinavia 1977.

Seit dem Jahre 1970 hat an der Stockholmer Universität ein Baltisches Institut (Baltiska Institutet) seinen Sitz. In den erwähnten Symposien spielten vor allem die gegen Ende des Zweiten Weltkrieges vor der Roten Armee geflüchteten und emigrierten Wissenschaftlerinnen und Wissenschaftler aus Lettland und Litauen eine bedeutende Rolle, deren Tätigkeit eine längere Zeit in der Sowjetunion und den ihr ideologisch angeschlossenen Ländern

2 Es handelt sich um den Vortrag „Die Baltistik in Schweden" auf der 36. Baltistenkonferenz am 18. März 1977. Rainer Eckert. Der Baltistenkreis zu Berlin e.V. und seine Vorgängereinrichtung, Peter Lang Verlag, Frankfurt am Main 2015, 128. 
ignoriert wurde. Doch in den sechziger und darauf folgenden Jahren kam es zu gewissen Entspannungen und sich mehrenden Kontaktaufnahmen in der Wissenschaft, dem natürlich die neutrale Politik Schwedens entgegen kam.

Dies zeigte sich vor allem in der Teilnahme einer größeren Gruppe von Wissenschaftlerinnen und Wissenschaftlern an der überragenden Festschrift für Prof. Dr. Chr. S. Stang33. Von insgesamt 75 Autoren, die sich an diesem Werk beteiligten, stammt mehr als ein Drittel (genau 27) aus der Sowjetunion und den mit ihr liierten Ländern. Besonders aufschlussreich ist die Beteiligung von 10 Autoren aus Litauen und Lettland.

Wie in vielen Ländern ist die Baltistik eng mit der Slawistik verbunden. Das galt in den vergangenen Dezennien für die Universitäten in Lund, Uppsala und Stockholm, wobei besonders in den letzten Jahren ein Trend zu einer gewissen Eigenentwicklung vor allem in Stockholm auszumachen ist.

Außerdem ist zu beachten, dass das Finnische eine besondere Rolle in den schwedischen Hochschulen spielte, vor allem an der Universität in Umeå. Auch das Westfinnische (hier natürlich Estnisch) und das Saamische ergänzen das Interesse am Finno-ugrischen in der schwedischen Wissenschaftslandschaft.

Eine besondere Situation für die Baltistik in Schweden war in der Nachkriegszeit durch den Zustrom einer bedeutenden Anzahl baltischer Emigranten zu verzeichnen. So kamen aus Estland und Lettland etwa je 4.500 Emigranten, aus Litauen etwa 400. Dieser Umstand hatte einen gewissen Einfluss auf die Entwicklung und Etablierung von Lehr- und Forschungseinrichtungen für baltische Philologie. Eine Reihe von Wissenschaftlern und Lehrkräften aus Lettland und Litauen nahm ihre Tätigkeit auf. Aber auch viele Hörerinnen und Hörer kamen aus Emigrantenkreisen, zunehmend auch aus anderen westlichen Ländern, in die Balten emigriert waren.

Kennzeichnend ist weiterhin für die Baltistik in Schweden eine deutliche Orientierung auf das Studium der baltischen Gegenwartssprachen Lettisch und Litauisch, ihre Literaturen sowie ihre Geschichte und Landeskunde. Zumindest an der Universität Stockholm wird die Baltistik als eigenständiger Lehr- und Forschungsgegenstand betrieben und nicht wie andernorts in früheren Zeiten als Anhängsel der Indogermanistik oder Slawistik mit einer deutlichen Reduzierung auf das Litauische. Gleichzeitig ist zu betonen, dass in Schweden der historischen Komponente des Baltischen (Sprach-, Literatur- und Landesgeschichte, Folklore) die gebührende Aufmerksamkeit geschenkt wird. Das Lettische wurde in diesem Zusammenhang gleichrangig zum Litauischen entwickelt und behandelt.

3 Donum Baltikum. To professor Christian S. Stang on the occasion of his seventieth birthday, 15 March 1970. Edited by Velta Rūķe-Draviņa, Stockholm1970, 598 S. 


\section{Zu einigen Traditionslinien}

Die Baltistik in Schweden besitzt, wie in einer Reihe anderer Länder, in der Vergangenheit eine nicht unbedeutende Tradition, aus der hier aus Raumgründen nur einige wenige Momente dargestellt werden können. Kennzeichnend war auch hier in der Regel ein engerer Bezug zur Indoeuropäistik und/oder zur Slawistik.

Prof. Tore Torbjörnsson veröffentlichte bereits 1901 in Uppsala seine zweibändige, grundlegende Studie „Die gemeinslawische Liquidametathese“, die auch ein reiches baltisches Material enthält.

An der Universität Uppsala war Prof. Richard Ekblom erfolgreich auf slawistischem und baltistischem Gebiet tätig. Er arbeitete mit Prof. Jānis Endzelīns von der Universität Riga und mit dem Phonetischen Institut der Universität Stockholm zusammen bei der experimental-phonetischen Untersuchung der lettischen Intonation. Im Jahre 1933 erschien dazu sein Buch „Die lettischen Akzentarten“.4

Prof. Knut-Olaf Falk hatte in den 20er und 30er Jahren das Lektorat für Schwedisch an der Universität Kaunas inne. Er trat später mit einer Reihe von baltistischen Arbeiten, darunter Beiträgen zur Slawisierung litauischer Ortsnamen und Antroponyma, auf und wirkte lange Jahre als Baltist an der Universität Lund. ${ }^{5}$ Er und Prof. Dr. J. Safarewicz hatten Anteil an der Gründung der Kommission zum Studium der balto-slawischen Beziehungen beim Internationalen Slawistenkomitee 1963.

\section{Zur weiteren Entwicklung der schwedischen Baltistik in der Nachkriegszeit bis in die 70er Jahre}

Aus dem Dargestellten wird deutlich, dass es in der Nachkriegszeit in der schwedischen Baltistik wichtige Impulse in vor allem drei Richtungen gab:

1) in einer auf das praktische Sprachstudium ausgerichteten Lehre, wobei, wie bereits erwähnt, das Lettische gleichberechtigt neben dem Litauischen behandelt wurde und die spezielle Beziehung zum Livischen die Beachtung des Finnougrischen verstärkte;

4 Bereits 1927 war in Uppsala-Leipzig seine Arbeit „Zur Physiologie der Akzentuation langer Silben im Slawo-Baltischen“ erschienen.

5 Man vgl. „Ze studiów nad slawizacją litewskich nazw miejscowych i osobowych: O wtórnej funkcji sufiksu -ec; o nazwach miejscowych na -ance“. Scando-Slavica, IV (1963), 87-103; „O metodach slawizacji litewskich nazw osobowych i miejscowych, o genezie i rozpowszechnieniu nazw na -ance“. Språkliga bidrag, vol. 9, Lund 1966, 1-16. 
2) eine Ausweitung auf die verschiedensten Teilgebiete der Sprachwissenschaft (über die Lautlehre, Akzentologie, Grammatik und Lexik hinaus), auf Bereiche der Dialektologie, Onomastik, Geschichte der Schriftsprachen, Phraseologie, Sprache der Folklore, Kindersprache etc.;

3) eine vertiefte Erforschung der baltisch-slawischen Sprachbeziehungen.

Hier sind vor allem die zahlreichen Arbeiten von Prof. P. Arumaa, K. Draviņš und Prof. V. Rūķe-Draviņa zu nennen.

Der aus Estland stammende Prof. Peeter Arumaa war an den Universitäten Lund und Stockholm tätig und befasste sich u.a. mit der Erforschung der litauischen Dialekte ${ }^{6}$, der Geschichte der litauischen Personalpronomina ${ }^{7}$ und der Nominalstämme auf $-u$ im Baltischen und Slawischen ${ }^{8}$. Einen bedeutenden Platz in seiner dreibändigen „Urslavischen Grammatik“9 nimmt das Baltische ein. Er äußerte sich auch in mehreren Arbeiten speziell zum Balto-Slawischen. ${ }^{10}$

Kārlis Draviņš, der an der Universität Lund angestellt war, gab ein wichtiges Sprachdenkmal des Altlettischen ${ }^{11}$ heraus und veröffentlichte zusammen mit seiner Frau Velta Rūkse eine Serie von Beschreibungen über die Mundart seiner Heimat Stenden ${ }^{12}$.

Prof. Dr. V. Rūķe-Draviņa veröffentlichte 1959 ihre Habilitationsschrift über die Diminutive im Lettischen ${ }^{13}$, ein Standardwerk zu dieser für das Baltische (und Slawische) so charakteristischen Kategorie. Im Jahre 1949 hatte sie einen Beitrag, den sie „Die Muttersprache in der Emigration“

${ }_{6}$ Peeter Arumaa. Litauische mundartliche Texte aus der Wilnaer Gegend. Dorpat 1930.

7 Peeter Arumaa. Untersuchungen zur Geschichte der litauischen Personalpronomina, Tartu 1933.

${ }^{8}$ Peeter Arumaa. Sur l'histoire des adjectifs en - $u$ en balto-slave. Årsbok 1948-1949, Lund 1951.

9 Peeter Arumaa. Urslavische Grammatik. Bde 1-3. Heidelberg 1964-1982.

${ }^{10}$ Ich verweise nur auf zwei Arbeiten: Die Verwandtschaftsverhältnisse zwischen Baltisch und Slavisch. Zeitschrift für slavische Philologie, Bd. 24 (1956), 9-28 und De l'unité balto-slave. Scando-Slavica, t. IX (1963), 70-86.

${ }^{11}$ Evangelien und Episteln, ins Lettische übers. von Georg Elger, Bd. 1. Texte. Herausgegeben von K. Draviņš, Lund 1961.

${ }^{12}$ Man vgl. die Hefte der Slaviska och baltiska studier, Slaviska institutionen vid Lunds Universitet:

(1) K. Draviņš \& V. Rūķe. Laute und Nominalformen der Mundart von Stenden. 1. Einleitung, Akzent und Intonation, Lautlehre, 1955; (2) Dieselben. Laute und Nominalformen der Mundart von Stenden. 2. Wortbildung, Deklination und Komparation, 1956; (3) Dieselben. Verbalformen und undeklinierbare Redeteile der Mundart von Stenden. Verben, Adverbien, Präpositionen und Präfixe, Partikeln, Konjunktionen, 1958 und (4) Dieselben. Interjektionen und Onomatopöie in der Mundart von Stenden, 1962.

13 Velta Rūkse-Draviņa. Diminutive im Lettischen. Lund 1959, 408 S. 
nannte, veröffentlicht, der treffend die Problematik einer ganzen Reihe von Beiträgen aus ihrer Feder in dieser Zeit umriss. In den Jahren von 1945 bis 1975 brachte sie, vorwiegend in Schweden, aber auch in einer Reihe anderer Länder 127 Arbeiten heraus, die ein breites Feld der Baltistik betreffen. Im Mittelpunkt steht natürlich das Lettische, das aus den verschiedensten Blickwinkeln einer Betrachtung unterzogen wird, wobei die einzelnen Beiträge weit über die Fragen der Struktur der baltischen Sprachen hinausreichen. Es werden Probleme der Onomastik, des Spracherwerbs und der Kindersprache, der Übersetzungswissenschaft und vieles andere behandelt. Ein hoher Grad von Universalität ihrer gesamten Sprachbetrachtung deutet sich an. Im Jahre 1974 brachte Prof. Rūkse-Draviņa das erste phraseologische Wörterbuch des Lettischen in Schweden heraus. ${ }^{14}$ Sie zählt zu den Begründern dieser jungen sprachwissenschaftlichen Disziplin.

In enger Beziehung zu den erfolgreichen Forschungen steht bei Prof. Rūķe-Draviņa ihre beispielhafte, viele Teildisziplinen umfassende Lehre an den Hochschulen. Sie hielt von 1948 bis 1968 Lehrveranstaltungen zu den baltischen Sprachen an der Universität Lund und hatte von 1969 bis 1984 die Leitung der Baltistik an der Stockholmer Universität inne, die sie während ihrer Tätigkeit zu einer der führenden Ausbildungsstätten der Baltistik in Europa und in der Welt entwickelte. In dieser Zeit belegten bis zu 20 Studenten und Doktoranden aus vielen Ländern jährlich das Baltistikstudium in Stockholm. Als Schülerin von Prof. Dr. J. Endzelīns, Mitglied der Königlichen Schwedischen Humanistischen Akademie der Wissenschaften seit 1980 und Trägerin weiterer zahlreicher Ehrungen zählt sie zu den hervorragendsten Vertretern in der Geschichte der Baltistik.

\section{Zur Zusammenarbeit von Baltisten und Slawisten aus Schweden und der DDR}

Eine erste wissenschaftliche Zusammenarbeit auf dem Gebiete der Slawistik setzte relativ früh in der Nachkriegszeit ein. Hier wären vor allem die Kontakte von Prof. Dr. Rudolf Růžička und Prof. Dr. Heinz SchusterŠewc zu den Universitäten Stockholm und Göteborg zu erwähnen. Die schwedischen Professoren Anders Sjöberg (Universität Stockholm), Gunnar Jacobsson (Universität Göteborg) und Thorsten Andersson (Universität Uppsala) besuchten die Universität Leipzig.

14 Velta Rūḳe-Draviņa. Vārds īstā vietā. Frazeolog̣ismu krājums (Das richtige Wort am richtigen Fleck. Eine Sammlung von Phraseologismen), Stockholm 1974, 338 S. 
Seit dem V. Internationalen Slawistenkongress in Warschau 1973 konnte ich persönliche Kontakte mit Frau Prof. Dr. V. Rūkse-Draviņa aufnehmen. Im Jahre 1974 trat sie mit Gastvorlesungen an der Leipziger Universität auf. So hielt sie Vorlesungen zu den Zahlwörtern im Baltischen und zur konfrontativen Phraseologie im Lettischen, Litauischen und Deutschen sowie einem Vortrag über slawische Onomastik.

Von Frau Prof. Dr. Rūķe-Draviņa erhielt ich ab 1976 jeweils die Einladungen zu den Internationalen Baltistischen Konferenzen an der Universität Stockholm, für die ich ihr sehr dankbar war. 1989 führte ich als leitender Moderator das Promotionsverfahren von Frau Konstance Klava an der Universität Stockholm durch. Im gleichen Jahr hatte ich von der Universität einen dreiwöchigen Studienaufenthalt in Stockholm zu Forschungsarbeiten erhalten.

Auf der 79. Konferenz des Berliner Baltistenkreises hielt Frau Prof. Dr. Baiba Kangere einen Vortrag über die lettische und litauische Literatur im Exil der Jahre 1950 bis 1990 und Dr. Kārlis Kangeris (beide von der Universität Stockholm) referierte über „die Kulturpolitik der deutschen Okkupationsmacht im Generalkommissariat Lettland 1941-1945“. 1989 besuchte Frau Dr. Aija Priedīte Berlin. In den letzten Jahrzehnten gab es einen regen wissenschaftlichen Austausch und enge Kontakte zu Herrn Prof. Dr. Pēteris Vanags, dem ich sehr viel in meinem baltistischen Werdegang verdanke.

Im letzten Abschnitt bin ich weit über den zeitlichen Rahmen hinausgegangen, um zu zeigen, dass die in den siebziger Jahren geknüpften Kontakte zwischen den ostdeutschen und schwedischen Wissenschaftlern besonders nach der Wiedervereinigung Deutschlands 1989 weiter ausgebaut wurden und eine kontinuierliche Fortsetzung fanden. Mich persönlich erfüllt der vorliegende Bericht mit großer Genugtuung und Freude über die Gestaltung fruchtbarer Beziehungen zwischen der deutschen Baltistik und der elitären skandinavischen Baltistik (konkret der schwedischen Baltistik, die hier Gegenstand war mit dem noch zu ergänzenden Hinweis auf besonders tragende Kontakte zu solchen großen norwegischen Baltisten wie Prof. Dr. Christian S. Stang, Prof. Dr. Terje Matthiassen und Prof. Dr. Helge Rinholm).

Rainer Eckert

Emeritus

Murtzaner Ring 16

12681 Berlin, Deutschland

rainer_eckert@gmx.net 
KOPSAVILKUMS

\section{Par baltistikas pētījumiem Zviedrijā pagājušā gadsimta 70. gadu vidū}

\section{Rainer ECKERT}

Rakstā sniegts īss ieskats baltu valodu pētniecībā Zviedrijā 20. gadsimtā. Tuvāk apskatītas valodnieku aktivitātes septiņdesmitajos un astoņdesmitajos gados. Rakstā minētas nozīmīgākās publicētās grāmatas, kā arī Zviedrijā rīkotās zinātniskās konferences. Atsevišḳi aplūkota arī bijušās VDR un Zviedrijas baltistu un slāvistu sadarbība pagājušā gadsimta septiņdesmitajos un astonidesmitajos gados.

\section{SUMMARY}

\section{On Baltic Studies in Sweden around the Mid-Seventies of the Last Century}

\section{Rainer ECKERT}

The article provides a brief overview of research on the Baltic languages in Sweden in the 20th century. The activities of linguists in the 1970s and 1980s are examined in detail. The article mentions the most important books published, as well as scientific conferences on Baltic studies held in Sweden. The co-operation between Slavists and Balticists of the former GDR and Sweden in the 1970s and 1980s is also briefly discussed. 


\title{
REDUPLIKĀCIJA GEORGA MANCEḶA SPREDIḲU GRĀMATĀ (1654)
}

\author{
Anna FRĪDENBERGA \\ Latvijas Universitäte
}

\section{Ievads}

Reduplikācijas parādība latviešu valodā ir samērā maz pētīta. Latviešu valodniecībā, pirmkārt, reduplikācija ir aplūkota Jāņa Endzelīna „Latviešu valodas gramatikas“ II dạ̧ā „Vārdu mācība“ (Endzelīns 1951: 255), kuras sākumdaḷa veltīta vārddarināšanai. Materiāls aplūkots trijās apakšnodalạas - „Salikteņi“, „Reduplikācija“ un „Nominālo celmu atvasināšana“, un reduplikācijai veltīts viens paragrāfs, kurā J. Endzelīns aplūko vēsturiski reduplikācijas izmantošanu vārddarināšanā. Viņš min, ka nepārprotama reduplikācija latviešu valodā sastopama gandrīz tikai nominālcelmos, un nosauc vairākus piemērus, kā māminga, murmulis, gaigala, paipala, teteris, titilbis, vaivarini un dažus citus vārdus, kas pēc būtības ir onomatopoētismi.

Valodniecības pamatterminu skaidrojošajā vārdnīcā reduplikācija definēta kā vārda daḷas daḷẹjs vai pilnīgs atkārtojums, piemēram, latviešu valodas vārdos paipala, vāvere, teteris, murmulis (VPSV 322). Tātad šì definīcija arī ir no vārddarināšanas viedokḷa, un minēti tie paši J. Endzelīna piemēri. Par reduplikāciju jeb divkāršojumu runā arī tad, ja ir vārda, vārdu savienojuma vai teikuma dạlas piln̄̄gs atkārtojums tai pašā formā (VPSV 95). Jaunajā latviešu valodas gramatikā reduplikācija atseviški nav aplūkota, bet pieminēta vairākās vietās - pie formveidošanas (LVG 304), kā viens no īpašības vārdu gradācijas izteikšanas pañēmieniem (LVG 406) un sintaksē - runājot par atkārtotiem teikuma locekliem (LVG 809). Literatūrā citās valodās reduplikācija tiek aplūkota kā vārddarināšanas process, kas ir raksturīgs daudzām pasaules valodām, piemēram, reduplikācija ir ḷoti produktīvs process austronēziešu valodu saimes valodās, bet sastopama arī indoeiropiešu valodās, tajā skaitā ǵermāņu, romāņu un slāvu (Štekauer 2015: 103-105).

Reduplikācijai latviešu valodā vērību pievērsusi Daina Nītiņa, viņa aplūkojusi vienkopus dažādus saknes, celma vai visa vārda atkārtošanas gadījumus, kas parasti tiek analizēti atsevišksi vārddarināšanas, morfologiijas vai sintakses aspektā (Nīinna 2000). Daina Nìtiņa raksta, ka reduplikāciju, kas izpaužas kā saknes, celma vai visa vārda atkārtošana, latviešu valodā izmanto pastiprinājuma izteikšanai. ,Tā uzskatāma par morfoloǵiski sintaktisku vai bieži vien arī stilistisku parādību, turklāt morfolog̣iskais, sintaktiskais un stilistiskais aspekts parasti ir nesaraujami saistīti.“ (Nīinģa 2000: 197) 
Reduplikācijas parādība tikusi pētīta kā stilistisks izteiksmes līdzeklis, kas bieži sastopams latviešu daiḷliteratūrā, folklorā. Arturs Ozols savā grāmatā „Latviešu tautasdziesmu valoda“ pie leksikostilistiskajiem teicieniem aplūkojis tautolog̣iju — vienas saknes dažādas leksiskas nozīmes vārdu lietojumu teikumā, kas ir viens no atkārtojuma veidiem (Ozols 1993: 394). Tautolog̣ijas un atkārtojuma nozīmi tautasdziesmās uzsvēris arī latviešu tautasdziesmu stilistikas pētnieks Ludis Bērziņšs, viņš uzskata, ka, šos līdzekḷus izmantojot, , jēdziens vairāk izceḷas, dabū lielāku uzsvaru, nekā to vienkārši pieminot““ (Bērziņš 1940: 280). Turklāt tautoloǵija raksturīga gan tautas dzejā, gan arī oratoriem. Ludis Bērziņš pētījis arī Georga Manceḷa darbu valodu, kur uzsvēris, ka viņš, izteiksmei spēku piešksirdams, labprāt lieto visādu veidu atkārtojumus. Substantīvus G. Mancelis visbiežāk pastiprinot ar tā paša celma substantīvu daudzskaiț̣a ǵenitīvā, piemēram, pišş̧ lu pišs̆los, pelnu pelnos. Savukārt, ja pastiprināmais priekšstats ir verbālas dabas, tad to papildina vai nu ar tā paša verba divdabi, arī nenoteiksmi, vai tās pašas saknes substantīvu vai adverbu (Bērziņš 1944: 10).

Māra Grudule ir pētījusi reduplikāciju Kristofora Fīrekera (1612?-1685?) atdzejojumos, uzskatot, ka tieši pēc K. Fīrekera parauga reduplikācija latviešu atdzejojumos kḷūst par iecienītu un ierastu parādību (jānem vērā, ka vācu valodā un oriǵinālā šādas parādības nav). M. Grudule secina, ka reduplikācija K. Fīrekera tekstos saistāma, iespējams, gan ar latviešu folkloras, gan ar sarunvalodas ietekmi (Grudule 2014: 28). Vienā no G. Manceḷa vārdnīcas „Lettus“ eksemplāriem ir ar K. Fīrekera roku rakstīti papildinājumi un piezīmes. Interesants ir fakts, ka daži no tiem saistīti tieši ar reduplikāciju, piemēram, tautasdziesmas rindas - Gan es malu malamāa / Vēl pieberu beramā, -, kā arī teiciens nelaime nelaimes galā (Grudule 2014: 27-28).

Rakstā tiks aplūkotas dažādas reduplikācijas izpausmes (atkārtojumi, nominālie, adverbiālie, verbālie reduplikatīvie vārdu savienojumi) Georga Mancẹ̦a (1593-1654) sprediķos, kur šie atkārtojumi ir izmantoti kā stilistisks līdzeklis. Reduplikatīvie vārdu savienojumi ir ekscerpēti no Georga Manceḷa Sprediķu grāmatas jeb Postillas visām trim dạ̧ām. Kā zināms, Georga Manceḷa Sprediķu grāmata trijās dạ̦ās jeb „Lang-gewünschte Lettische Postill“ (1654) ir pirmais oriğinālsacerējums latviešu valodā, ar šo grāmatu G. Mancelis nodibina rakstos latviešu prozu, tajā pirmo reizi parādās plašāki latviešu valodas teksti, kas nav tulkojumi. G. Manceḷa Sprediķu grāmata balstās uz reliğiskās retorikas paṇēmieniem (Krēsliņš 1992: 215), tai raksturīga tēlaina valoda, kupla un daudzkrāsaina izteiksme, sinonīmi un atkārtojumi kā stilistiski līdzekḷi. Dažādu stilistisko slāṇu, 
krāšno metaforu, salīdzinājumu un citu izteiksmes līdzekḷu izmantojums ir tipisks baroka laikmetam (Apīnis 1993: 179). Maija Baltiņa, rakstot par G. Manceḷa sprediķiem, runā par īpašu teksta dramaturğiju. Sprediķ viņa raksturo kā sacerējumu, „kas ir senas izcelsmes, bagāts tradīcijām, spilgts oratoriska tipa teksts“ (Baltiņa 1994: 57).

\section{Atkārtojums}

Viens no reduplikācijas paveidiem ir vārda atkārtošana. G. Manceḷa Sprediķu grāmatas tekstā, pirmkārt, sastopama vienkārši kāda vārda (vai vārdformas) atkārtošana kā nozīmes pastiprinājums. Šim atkārtojumam var būt nozīmes nianses. Piemēram,

Tahda Nhelaime gir zeeta / zeeta Ackminaina Vhdens=Kruhfe.

(Manc1654_LP1, 1483)

Resp., atkārtojums cieta, cieta šajā tekstā tiek lietots ar nozīmi 'ḷoti cieta'.

Śchi Semme dauds dauds Zillwäko Afśini gir eedferufśi / und gir itt peedfärufśeeß .. (Manc1654_LP2, 374\{354 29 )

Arī šajā piemērā atkārtojums daudz, daudz lietots ar nozīmi 'l̦oti daudz'. Savukārt nākamajā piemērā visiems, visiems lietots ar nozīmi 'pilnīgi visiem'.

Ścho Schälaftibu dahwa taß fchehligs Deews wifśeems /

wifśeems Zillwäkeems / irr teems / kattri to Schälaftibu nitzina.

(Manc1654_LP2, 353\{331 $\}_{10-11}$ )

Tomēr ir arī l, loti daudz piemēru, kur atkārtojams neizsaka izmērāmu pastiprinājumu, tas nenozīmēe, piemēram, 'ḷoti', bet drīzāk ar šo atkārtojumu tiek kaut kas uzsvērts, šādi atkārtojumi G. Manceḷa tekstiem ir ḷoti raksturīgi. Sprediķos ir šādi piemēri ar mūsu, mūsu un paties, paties. Piemēram,

Wings nhe finnaja no nhe neekadeems Ghräkeems / śacka taß Apuftuls Pahwils / tapehtz nhe wajadfeja winjam zeeśt und mirrt söwis dehly; bett ko Wings zeetis gir / to Wings muhfśs / muhfśso dehl gir zeetis. (Manc1654_LP1, 277 15 )

Pattee $\boldsymbol{\beta}$ / pattee $\boldsymbol{\beta}$ / Eß śacku jums / ja juhß tam Tähwam ko luhxeeta / tad taß jums doh $\beta$. Luhdfeeta / tad juh $\beta$ dabbuifśeeta. (Manc1654_LP1, 48912)

Pēdējais gadījums ar paties, paties ir ḷoti raksturīgs piemērs, kas sastopams daudzās un dažādās variācijās. Tāpat reliğiskajos tekstos, un it sevišksi Manceḷa sprediķ̧os, bieži tiek atkārtots arī vārds āmen. Piemēram,

Pafśarghi mums no tahß Elleß / O tu śalldais JEfu Chrift /

katters tu Zillwehx peedfimmis efśi / Amen / Amen / Amen.

(Manc1654_LP2, 355\{335\}29-31) 
Dažreiz tiek atkārtots arī vārdu savienojums vai vesels teikums. Piemēram,

E $\beta$ luhdfo und śirrdighe luhdfo / peedohd mann / O Kungs peedohd mann / nhe laid mann mannohß Ghräkohß śamaitaht / und nhe laid to Śohdibu muhfcham us mann pallickt ..

(Manc1654_LP1, 3949)

Piemērā ietvertais Es lūdzu un sirdīgi (resp., 'no sirds, dedzīgi') lūdzu demonstrē, ka nereti sprediḳu tekstos kāds vārds atkārtojas ar kaut kādām variācijām. Savukārt nākamajā piemērā redzams, ka vārds visas atkārtojas pat trīs reizes.

Wifśas / wifśas / wifśas leetas juhß dabbuifśeeta no Deewu / ko juh $\beta$ eekfchan to Wahrdu JEfu Chrifti luxeeta .. (Manc1654_LP1, 49911)

\section{Pastiprinājuma geenitīvs un nominālie vārdu savienojumi}

Sastopams ir saknes vai celma variēts atkārtojums atškirīīgu vārdformu vai vārdu sastāvā. Daina Nīinna min, ka sevišksa nozīme latviešu valodā ir pastiprinājuma g̊enitīvam, kas parādās gan substantīvu, gan adjektīvu sistēmā (Nīiņa 2000: 198). G. Manceḷa sprediķos īpaši raksturīgs šāda pastiprinājuma genitīva lietojums substantīviem. Sprediḳu grāmatā ir sastopami šādi vārdu savienojumi: $d r u s k u=d r u s k a \bar{s}$ (drusku=druskos), gabalu=gabalos, pīšllu=pīšșos, pelnu=pelnos (pelna=pelnos), gaisa=gaisās (arī gaisa=gaisos, gaisu gaisu), malu=mali (ar̄ mala=mali), gala=galam (galu galām). Piemēram,

drusku=druskos

Taß Proweets Daniels klua py Laweem / plehfśigheem Swähreem mäfts / teem by to Drußko=Drußkoh $\boldsymbol{\beta}$ śaplohśiet / tadehl ka taß Deewam kallpoja. (Manc1654_LP2, 288\{268\} $\}_{5-6}$ ) gabalu $=$ gabalos

Tahdu Nhelaim ta Mahte py śawu Bährnu rädfädama / ghribbeja Winjai Sirrds ghabbalo=ghabbaloh $\boldsymbol{\beta}$ fprahkt / unnd no Muttes ißlehkt. (Manc1654_LP1, 304 13 )

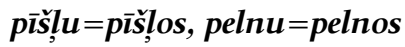

.. ka töw titzeht buh $\beta$ / töw / tawahm Meefśahm buh $\beta$ paftara Deena' / jebfche tu śapuwis / śatrudejis / pieśchlo=pieśchloh $\boldsymbol{\beta}$ / pällno=pälnoh及 Semmeh tappis / tomähr attkal dfiewam tapt / aukfcham zellteeß / und preekfch Deewu Debbefśieß Ghohda` nahkt. (Manc1654_LP1, 4003)

Pēdējā piemērā ir pat veseli divi šādi reduplicētie vārdu savienojumi —

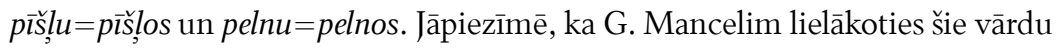


savienojumi ir rakstīti kopā - ar biedruzìmi, tātad uzsverot reduplikatīvā savienojuma veselumu. Parasti šo savienojumu pirmais komponents ir substantīvs daudzskaitḷa g̊enitīvā. G. Mancelim ir gan malu=mali ar daudzskaitḷa ǵenitīvu pirmajā dạ̣ā, gan vairākkārt lietots arī mala=mali. Piemēram,

malu $=$ mali

MEf'sias taß Kungs / muhf'so Peftitais JEfus CHRJftus runna ar tha Koninja Dawida Mutt: Lai peeminn (mannas ghaufchas Mohkas unnd ruhktas Nahwes) wif'śas Paf'́aules Malo=Mali.

(Manc1654_LP3, 716)

\section{mala $=$ maliem}

Tick by taß Ghadds pa=ghajis / tad fwefścha Tauta usklieda no wifśeem Mala=Maleem / tee ißpohftija wifśu ścho Semm / nhefchehlighe. (Manc1654_LP1, 184 22)

Varētu domāt, ka vārdu savienojumam mala=mali pirmajā daḷā ir vienskaitḷa g̊enitīvs no mals 'mala', lai gan G. Manceḷa vārdnīcā „Lettus“ ir sieviešu dzimtes forma mala - Bort / Malla (Manc1638_L, 39A 3 ). (Bet - No wifśeems maleems, Manc1638_L, 18B 8-9.) $_{\text {. }}$ Turklāt G. Manceḷa tekstos bieži lietoti arī ar biedruzīmi rakstīti vārdu savienojumi (vai salikteņi), kuru pirmais komponents ir sieviešu dzimtes substantīvs nominatīvā (cauna=cepure, galva =skremel̦š̌, $k \bar{a} j a=$ papēži $)$. Tomēr jāpiezīmēe, ka nereti tekstos tiek variētas dažādu celmu formas, un daudzskaitlī bieži vien arī sieviešu dzimtes substantīviem tiek lietota vīriešu dzimte. Piemēram, G. Mancelim ir gan malas, gan mali, gan druskas, gan druski u. c. Sprediķos sastopams arī darinājums mal=malināas, kur pirmais komponents nav substantīvs génitīivā, bet ar atmestu galotni, tādējādi veidojot salikteni.

\section{mal=maliñās}

Aifto kad Zillwäka=Bährni apniek Deewa Wahrdu / nhe ghribb to sirrdighe klauśiet / ka tee tha dfiewotu / ka Deewa Wahrds mahza / tee nhe zeeni to / ihten ka pee=ähduśchi Bährni / kattri wifśah $\beta$

Mall=Mallinjahß / wifśoh $\beta$ Kacktinjoh $\beta$ Mais mähta / und leek wafahteeß / kattru daśch i $\beta=$ allzis Zillwähx ar śalldu Mutt $a p=$ laifidameeß $a p=$ ähftu .. (Manc1654_LP1, 425)

Interesants darinājums ir mella=mellums, kura pirmajā daḷā ir adjektīvs g̊enitīvā. Nākamajā piemērā minēts visai paradoksāls teiciens mella=mellumā nobālējis:

mella $=$ mellum $\overline{\boldsymbol{a}}$

.. taß nabbags Ghrehzeneex $\boldsymbol{m a ̈ l l a}=\boldsymbol{m a ̈ l l u m a ̀ ~ n o b a h l e j i ß ~ / ~}$ no leelas ißbailes / tee triefśe und drebbe / ka Apśas=Lappa. (Manc1654_LP3, 199-10) 
Varbūt, ka mella=mellums ir G. Manceḷa darinājums, tomēr tas atgādina modeli, kur par adverbu sastingušas tagad vairs nesastopamās substantīva vienskaiț̣a instrumentāla senākās formas, kas beidzas ar -umu un kas parasti pastiprināja tās pašas saknes adjektīvu, piemēram, vecumu (vecs), pilnumu (pilns) (MLLVG 704). Mūsdienu valodā biežāk sastopamie šāda veida adverbi beidzas ar -um, piemēram, baltum balts, vecum vecs, tātad arī, iespējams, mellum mells.

Ar substantīva daudzskaitla g̊enitīvu pirmajā komponentā G. Mancelim

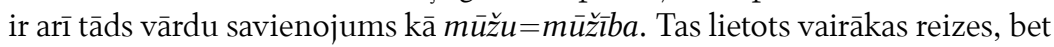
gan tikai vienā tekstā, tā ka, domājams, uzskatāms par Manceḷa darinājumu.

\section{$\boldsymbol{m u ̄ z ̌ u}=\boldsymbol{m u ̄ z ̌ z ̌} b a s$}

Wings gir no Muhfcho=Muhfchibas no śawas Buhśchanas weenu

Dählu dfimbdenajis par śawu pafśchu Ghiem / tha / ka nhe weens to warr i $\beta=$ dohwaht / ißpraft / ißrunnaht. (Manc1654_LP2, 107)

Šim darinājumam, iespējams, pamatā ir vārdu savienojums mūžz mūžos, kas arī ļ loti bieži sastopams G. Manceḷa tekstos.

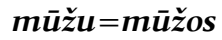

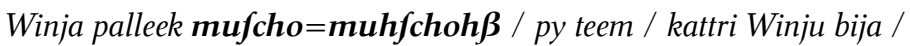
dfeed ta Jumprawa Maria. (Manc1654_LP1, 54627-28)

Nereti šie vārdu savienojumi ir ieguvuši adverbiālu raksturu, piemēram, mūžu mūžam.

\section{mūžu mūžam}

Tee Duhmi winjo Mohkas zellahß muhfcho muhfcham / und teem nhe gir Meers Deenas und Nacktis. (Manc1654_LP3, 18 30 )

Līdzīgi adverbiāls raksturs ir arī vārdu savienojumam mūž̀̆gi mūžam (tikai te pirmajā daliā nav lietvārda ğenitīvs, bet gan adverbs). Tas raksturīgs ne tikai G. Manceḷa sprediķos, bet arī vispār reliğiskajos tekstos, un, protams, tiek lietots arī mūsdienās.

\section{mūž̀̃gi mūžam}

Aifto kaß fcheitan nhe ghribb Deewa Namma`labpraht eet / tam buh $\beta$ pehtz ghalla muhfchighe muhfcham ar wifseems Wälleems Elles Vgguny palickt / und deckt. (Manc1654_LP1, 131 ${ }_{7}$ )

Acīmredzot vārdu savienojumi ar šīs saknes atkārtojumu G. Mancelim ir bijuši l̦oti iecienīti. Sprediķu grāmatā sastopams arī vārdu savienojums mūžu

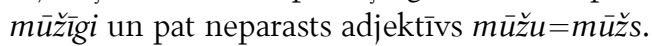

\section{$\boldsymbol{m u \overline { z } u} \boldsymbol{m u \overline { z } z \overline { g } g i}$}

To ißdfirrd Chriftus / eeśahk ścho Liedfibu / eekfchan kattru Wings rahda und mahza / ka tee śwähti Zillwäki gir / kattri Deewa Wallftiba` to Mais ähd / taß gir / kattri muhfcho muhfchighe Deewu räds / und ar wifśeem Śwähteem Debbefśies preezajah $\beta$ : (Manc1654_LP2, 31 21 ) 


\section{$\boldsymbol{m} \bar{u} z ̌ u=\boldsymbol{m u ̄ z ̌ s ~}$}

Taß Zillwähx gir Deewa Kallps / tahß Nopirrkśchanas dehḷ /

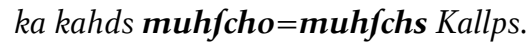

(Manc1654_LP2, 371\{351 $\}_{20}$ )

\section{Adverbiālie vārdu savienojumi}

G. Manceḷa sprediķos l̦oti raksturīgi ir adverbiālie reduplikatīvie vārdu savienojumi (vai vienkāršsi adverbi, kuros ir izmantota reduplikācija). G. Mancelim tie ir rakstīti gan ar biedruzīmi, gan arī atsevišķi, bet mūsdienu valodā šādi vārdu savienojumi nereti ir sakusuši jeb saauguši kopā un veido adverbu. G. Manceḷa sprediķos sastopami, piemēram, kārt kārtim, caur caurēm, ties=tiešam, tieš=tiešam, pār $=$ ārem, pār $=$ pārim u. c. Piemēram, vārdu savienojums kārt kārtim (gan ar biedruzīmi, gan atsevišksi rakstīts) G. Mancelim lietots ne reizi vien.

\section{kārt kārtim}

.. tad leeck Wings tomähr ścho Leetu śatziet teem Ghanneem ar leelu Ghohdu zaur weenu Engheli / ap kattru Deewa Spohfchums kahrt kahrtim fpiedeja / wiß Laux by fpohśch und atfpiedeja ka Vgguns. (Manc1654_LP1, 5417)

\section{kārt=kārtim}

Ar Splaudalahm und Śchṇurrghalahm Winja Waigs tha by apmätahts / ka Śuhdohß und Dubblohß kahrt=kahrtim wahrtietz. (Manc1654_LP3, 51 17)

Šì vārdu savienojuma nozīme varētu būt 'kārtu kārtām', 'vairākkārt', arī 'visapkārt'. Jāpiezīmē, ka Mīlenbaha un Endzelīna vārdnīcā (ME II, 202) pie [kārt] kārtim ir atsauce uz Glika Bībeles tulkojumu, bet G. Mancelis šo vārdu savienojumu neapšaubāmi lietojis agrāk. Pirmais lietojums, ko izdevies konstatēt, ir G. Manceḷa „Zīraka gudrības grāmatā“ (1631), grūti pateikt, vai agrāk tas rakstos ir sastopams. Turklāt kārt kārtim minēts G. Manceḷa vārdnīcā „Lettus“, un kā sinonīms tam ir dots vārds visapkārt. (Vārdnīcā minēts arī vārdu savienojums kārt kārtem.) Mūsdienu valodā lieto adverbiālu vārdu savienojumu kārtu kārtām 'vairākkārt, vairākkārtīgi'.

Bieži lietots adverbiāls vārdu savienojums caur caurēm, G. Manceḷa sprediķos tas rakstîts atseviški, mūsdienu valodā tam atbilst adverbs caurcaurēm 'pilnīgi'. Piemēram,

\section{caur caurēm}

Kaß Maife gir / to juhß pafśchi ghann finnaht / ka kluhft no

Labbibas=Millteem unnd Vhdeni zaur zaurehm miezita / 
i $\beta=$ kurrta zepply tah zäppta / ka tha gharrda / und to Zillwäku usturreht warr. (Manc1654_LP1, 386 11 )

G. Manceḷa Sprediķu grāmatā sastopams arī izteiciens caur un caur 'viscaur, pilnīgi', kas atbilst mūsdienu latviešu valodā lietotajam frazeolog̣ismam caur un cauri 'savā būtībā; pilnīgi, pavisam' (LFV 158). Piemēram,

\section{caur un caur}

Tfchettri Wieri / tfchettri Drahnas =Ghabbali: bett toh $\beta$

Wirrfśa=Śwahrkus nhe ghribb tee śaghraifiet / tee by nheśchuti/ bett aufti no aukfchenes zaur und zaur .. (Manc1654_LP3, 15412)

Ļoti bieži G. Manceḷa sprediķos ir sastopams adverbs ties=tiešam vai tieš=tiešam (arī ties tiešam, tieš tiešam, ties tiesam) 'tiešām', visdažādākajās variācijās, gan ar biedruzīmi, gan atsevišksi rakstīts kā vārdu savienojums. Šo adverbiālo savienojumu lieto tiešām viètā, lai apgalvojumu īpaši uzsvērtu. Mīlenbaha un Endzelīna vārdnīcā arī minēts adverbs tiestiešam (ME IV, 215), kā tāds, kas pastiprina pamatā esošo adverbu tiešām, un tiešām minēts ir piemērs no G. Manceḷa Sprediķu grāmatas. G. Mancelim vārds ir rakstīts gan ar s, gan ar š (gan ties=, gan tieš=). Piemēram,

\section{ties $=$ tiešam}

Vnd Syrachs mahza śawa`Ghramata`: Darri Labbam labb / tad kluhft töw taß baggatighe attmaxahtz / ja nhe no winju / tad teeß=teeścham notix no to Kunghu. (Manc1654_LP1, 125 22)

\section{tieš tiešam}

Deews taß Kungs gir to runnajis / taß darra to arridfan / Winja Wahrdi gir teefch teeścham. (Manc1654_LP1, 18325)

Adverbs tieš=tiešam sprediķos lietots arī ar nozīmi 'taisni'. Piemēram,

\section{tieš $=$ tiešam}

$\mathrm{Nu}$ Wings nhe ftaigha tudell teeśch=teefcham / bett leelu Liekumu

Wings apmett / unnd eet widdu zaur Samaria / kur puß Juddi

puß Paggañi / unnd zaur Galilea / kur dauds leeli Ghräzeneeki by.

(Manc1654_LP2, 2405-6)

Mīlenbaha un Endzelīna vārdnīcā vārds ties ir minēts kā sāisinājums no tiesa 'patiesi, [pa]tiešām' (ME IV, 212). G. Manceḷa sprediķos ir arī piemēri, kur secība ir otrāda, tātad lietots nevis adverbs vienā vārdā, bet vesels teikums tas ir tiešām ties(e) 'tas ir tiešām tiesa'. Iespējams, šis izteiciens arī ir reduplikatīvā savienojuma pamatā.

\section{tiešam ties}

Taß gir teeścham teeß / und dahrgs / auxts / zeeniegs Wahrds / ka JEfus Chriftus Pafśauleh nahzis / toh $\beta$ Ghrehzeneekus śwähtus darriet. (Manc1654_LP3, 76 21 ) 
Šāds izteiksmes veids ir ḷoti raksturīgs reliğiskajiem tekstiem, kas īpaši labi redzams nākamajā piemērā, kur adverbiālo savienojumu vēl pastiprina vārds patiesi - patiesi, tas ir tiešām tiesa:

\section{patiesi .. tiešam tiesa}

Patteefśse / taß gir teeścham teefśs / ko taß śwähtz Konings

Dawids śacka:

Tick auxte ka taß Debbeß par to Semm gir / leek Wings śawu

Schälaftibu eet par teems / kattri to bieftah $\beta$ / tick tahle taß Rietz gir no Wackareß / leek Wings muhfśsus Nofeeghumus no mums buht.

(Manc1654_LP2, 24016)

G. Manceḷa sprediķos lietots arī adverbs $p \bar{a} r=p \bar{a} r e m$ ( $\operatorname{ar} \overline{1} p \bar{a} r$ pārem), kā arī senāka forma $p \bar{a} r=p \bar{a} r i m$. Mūsdienu latviešu valodā attiecīgi ir adverbs pārpārēm 'ḷoti daudz, atliku likām'. Senajos tekstos šis reduplikatīvais savienojums pastiprina adverbu pārim vai pārem 'pāri'. G. Mancelim arī pār =pāri.

\section{$\boldsymbol{p a} \mathbf{a}=\boldsymbol{p a} \mathbf{a} e m$}

.. und kad leela Auka / leels Wehśch zellıhß / mätt auxtas Willnas / ka ta Laiwinja / eekfchan kattras Chriftus JEfus ghull / tohp ihten ka apklahta no Vhdeni / und tah $\beta$ Willnas pahr=pahrem eet / $\mathrm{ka}$ tee Mahzekli fchkeet / nu by teem dibbina` ghrimbt und apślickt .. (Manc1654_LP1, 1881)

\section{pār $=$ pārim}

Kaß tahdus Zillwäkus gir redfejis / und tee Prahta` durrah $\beta$ / tam Śchauśchalas pahr=pahrim eet. (Manc1654_LP1, 29915) $\boldsymbol{p} \bar{a} \mathbf{r}=\boldsymbol{p} \bar{a} \mathbf{r}$

Kad Vhdens eet par Aefära Dammbi / taß nhe gir labb / ka buhß tad tam Zillwäkam labb / kamm leeka=Dfehrens par Plaukścheem unnd wifśahm Eekfcham pahr=pahri eet? (Manc1654_LP3, 18512)

\section{Adjektīvi}

G. Manceḷa sprediķos sastopami arī reduplikatīvi adjektīvu vārdsavienojumi, lai gan mazāk nekā citas vārdšķiras. Pastiprinājumu izsaka adjektīva vien̄̄gs savienojums ar skaița vārdu viens, resp., viens vienīgs 'tikai viens', tas neapšaubāmi ir viens no stabiliem vārdu savienojumiem, kas ḷoti bieži atkārtojas gan G. Mancelim, gan arī citos reliǵiskajos tekstos. Šajā vārdu savienojumā pastiprinātāja funkciju veic adjektīvs.

\section{viena=vienīga}

Jck=kattris Zillwähx gir Ghanns / ja töw nhe gir wairahk ja=śarrgha / tad töw tomähr tawa weena=weenigha Dwehfśslite / 
ka kahds Jehrings ja=apdohma / und kohptina gir.

(Manc1654_LP1, 632-3)

Neapšaubāmi, raksturīgs vārdu savienojums visiem reliǵiskajiem tekstiem ir viens=vien̄̄gs Dievs. Piemēram,

viens $=$ vienigs

Gir tad trieß Deewi?

Adbilldi :

Nhe: weens weeniegs Deews gir / weena`Buhśchana` / bett trieß

Jhpafśchibas. (Manc1654_LP1, 400 25 )

Nākamais piemērs ir spilgts reliǵiskās retorikas paraugs.

Weens weeniegs Deews gir trieß ihpafśshas Jhpafśchibas /

und trieß ihpafśchas Jhpafśchibas gir weens weeniegs Deews.

(Manc1654_LP2, 928-29)

No vārddarināšanas viedokḷa interesants ir Sprediķu grāmatas 3. daḷā sastopamais adjektīvs, ko varētu uzskatīt par salikteni, tā sastāvdalăas savienotas ar biedruzīmi - sarku=sarkans. Šis darinājums atgādina latviešu valodā sastopamos salikteņus, kas radušies, saaugot kopā reduplicētiem vārdu savienojumiem, kur pirmajā dạ̣ā ir adverbs, adjektīva atkārtojums vai tās pašas saknes ğenitīvs, piemēram, sensenais, vecvecais, un ar šādu saknes atkārtojumu izceḷ, pastiprina īpašību (Ahero 1955: 45). Piemēram,

\section{sarku=sarkanām}

Śchiß Autz gir krahßnis / jaux / di fchans Tebbikis bijis /

no dfälltänahm Siedehm / śarrko=śarrkanahm / und

deegha=balltahm Siedehm .. (Manc1654_LP3, 1987-9)

\section{Verbālie vārdu savienojumi}

Tomēr visvairāk G. Manceḷa Sprediķu grāmatā ir dažādu paņēmienu, kā reduplikācija tiek izmantota verbu formu nozīmes pastiprināšanai. Tie ir verbālie vārdu savienojumi, kuros ir nenoteiksme, divdabis, adverbs, atvasinājums ar -šana.

\subsection{Nenoteiksme}

Verbālajos reduplikatīvajos vārdu savienojumos plaši tiek izmantota nenoteiksme. Tā, pastiprinot tās pašas saknes finīto formu, nostājas šīs formas priekšā. Piemēru ir l̦oti daudz (G. Mancelim visbiežāk kā salīdzinājums ar kā priekšā) - gaidìt gaida, skaldīt skalda, sijāt apsijāts, graizīt graizìja (graizīt izgraizìta), lidināt lidina, zibināt zibina, dīrāt nodīrāja, raudāt apraudāja, pilēt pil, kratìt izkrata, spīgulāt spīgula. Piemēram, 


\section{gaidit gaida}

.. zitti Enghel̦i ihten ka ghaidiet ghaida / kad taß Preddigkis pa ghallam / ka tee warr ee=śahkt dfeedaht / und Deewam par tahdu Schälaftibu mums parahditu / Pateitzibu śatziet.

(Manc1654_LP1, 53 20)

\section{pilèt pil}

Winja wif'śas Leetas appuśchko ar śaweem Dahwaneem / wiß pilleht pill ar Taukeem no winja Kahja=Papehfcheem. (Manc1654_LP2, 1317)

\section{graizìt izgraizìta}

Winja Muggura tappa śa=śchaufta / und ka

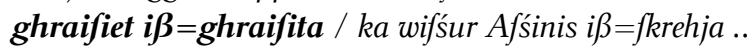
(Manc1654_LP1, 27728)

\section{lidināt lidina}

Vnd ka Deewa Gharrs Raddijuma Laika` us teem Vhdeneem liddinajahß / und toh $\beta$ ißtaiśijis / ihten ka kahda Wißta us Pauteem tupp und ka liddinaht liddina; ihten tha liddina taß śwähtz Gharrs allafch wehl par muhfśahm Śirrdehm / und ißtaifśa tahß pehtz śawu Prahtu / und ka winjam patiek.

(Manc1654_LP1, 53031)

\section{zibināt zibina}

Labbu Wieru Deews töw warr attraut / Launu Dußma=Puhki

Deews töw warr attdoht; Pirrmais Wiers töw ghlahßtija / ohtris tawus Kaulus laita ar Ślohtas=Kahtu / ka töw Atzis fibbinaht fibbina. (Manc1654_LP2, 271\{251 $\}_{31}$ )

\section{skaldït skalda}

Daśch Zillwähx śacka / taß Bafnizas=Kungs krahßne śacka Deewa Wahrdu / ka fkalldiet fkallda: bett kad tu tam waizahfśi / ko mahzija / ko śatzija Bafnizas=Kungs? (Manc1654_LP1, 1393-4) dīrāt nodīrāja

Ścheitan buhß mums nhe ween us Pilatu / kaß winju licka śchaufts ihs Afśinihm / nhe ween us teem Kaṛ̦a=Wiereem / kattri winju ka dieraht nodieraja / nhe ween us teem Juddeem / kattri winju Pilatam nodehwe / raudaht; bet mums buh $\beta$ muhfśo paffcha`Afoty Rohkahß eeśchaut / und ka mehß dfiewojuśchi äf'śam / apdomaht .. (Manc1654_LP3, 1125-6)

\section{raudāt apraudāja}

Aifto / kad teem Juddeem tick nhefchehligha Śirrds by prett to Kunghu JEfum / tad / redfi / tha Śaule / ka raddita Leeta śawa Radditaja 
Mohkas ka raudaht apraudaja / unnd tomähr nhe gir Chriftus tahß Śaules dehl zeetiß und mirris. (Manc1654_LP3, 157 27 )

Fragments no Sprediķu grāmatas 2. daḷas demonstrē reduplikatīvo savienojumu blīvo izmantojumu teksta tēlainības radīšanai. Te ir gan adverba atkārtojums grūt, grūt, gan arī divi verbālie vārdu savienojumi ar nenoteiksmi - kratīt izkrata un spīgulät spīgula:

Prohti nu / Manns Draugs / kahdi Laiki tad nahk / kad Deews śawu Dußmibu par teem Zillwäkeem ka krattiet ißkratta. Ghruht / ghruht gir tha Dfiewa Deewa Rohkas eekriśt. Kad Deews muhfśo Ghräko dehl eeśahk dußmoht / tad jämm wings tries Sobinus weena reifa` Rohka' / tee fpieghulaht fpieghula no leelas unnd afśas Trieśchanas / ar teem wings zährt pa kreifśu und pa labbu Rohku / nhe weenu nhe fchälodams. (Manc1654_LP2, 412\{392\}12-13)

\subsection{Divdabji}

Reduplikatīvajos verbālajos vārdu savienojumos nereti sastopami arī divdabji. Piemēram, sprediķos lietoti reduplikatīvie savienojumi, kuros ir dal̦eji lokāmais divdabis ar -dams. Divdabis var būt personu formas priekšā, kā nākdams (nākdama) nāk, bēgdams bēdze, žèlodams žèlo, gulēdami gul, spiezdami uzspiež, kā arī aiz tās, piemēram, ciet ciezdams. Piemēram,

nākdams nāks

.. taß Kungs nahgdams nahx / und nhe kahweh $\beta$ / und teems

Beßdeewigheems und Pullgotajeems ar Elles Vgguni wir $\beta$ winjo

Ghallwu attmaxah $\beta$. (Manc1654_LP1, 2111-12)

bēgdams bēedze

.. und taß Konings Sennacheribs patz ar leelu Kaunu bähgdams

behdfe / und tomähr Deewa Śohdu und Rohku nhe warreja ißbehgt. (Manc1654_LP1, 19329)

gulēdami gul

Dauds / kattri appakfchan Semmes ghullädami ghull / attkal usmohdieß / Zitti py muhfchighas Dfiewofchanas / zitti py muhfchighu Nheghodu und Kaunu. (Manc1654_LP2, 322\{302 $\}_{30}$ ) ciet ciezdams

Peeśuhta Deews töw / O Zillwäka=Bährns / kahdu Nhelaim / zeet zeeßdams / Deews töw pallidfehs. (Manc1654_LP2, 2622)

Bieži vien vērojama verba saknes atkārtošanās arī salīdzinājuma konstrukcijās ar divdabi: zied kā ziedēdami, sit kā sizdams, ciešu ko ciezdams, daraita ko darīdami, strādā kā strādādams, iet kā iedams, līst kā lìdams, lielìjās ko lielìdami, liedzās ko liegdams, arī daru ko darīdams, iemu kur iedams, domāju ko domādams. 


\section{zied kā ziedēdami}

Nhe finni tu / ka difchane feed tee Kohkalsi / kahdi difchani jauki Pugkieśchi gir zittai Sahlei / dauds jaukake tee feed / nhe ka Queefśis / bett lai feed ka feedädami / tomähr gir und palleek tee nickna Sahle? (Manc1654_LP1, 20511)

\section{sit $\boldsymbol{k} \bar{a}$ sizdams}

Scheitan eß ftahwu ka Śunns preekfch tawu Schälaftibas Ghalldu / Atzis at =plehtis us töw ween e $\beta$ fkattoh $\beta$ / śitt ka śißdams / nhe behgfchu eß no töw. (Manc1654_LP1, 3059-10)

\section{ciešu ko ciezdams}

Jhten tha dohma irr tu / Debbefśies buhß labbahk / laid eß ścheitan zeeśchu / ko zeeßdams. (Manc1654_LP1, 41614)

\section{daraita .. ko darīdami}

Bett darraita nu ko darridami / peeluhkojeeta ka juhßśchohß Weeśis ka peedärr śajämmaht / und tohß ar tieścheem Gräkeem nhe apfkumjoht: aifto kaß Deewa Bafnizu śamaitah / to Deews attkal śamaitahß / raxta taß Apuftuls Pahwils.

(Manc1654_LP1, 531 22)

\section{lielījās ko lielīdami}

Tee Warifeeri und Raxta=Mahzetaji arridfan ißdehweh $\beta$ par leeleem Mahzetajeem / bett / Deewam fchähl / tee nhe mahzija Deewa Wahrdu / laid tee leelijahß / ko leelidami / tee mahzija śawu pafśchu Mahzibu. (Manc1654_LP2, 10316) liedzās ko liegdams

Teitan nahk zitta Kallpone / tha ftippre Winjam us=ftahw / śatzidama us teem zitteem: Śchiß by arridfan ar JEfu no Nazareth / lai leedfahß / ko leegdams. (Manc1654_LP3, 6324)

Interesants ir piemērs no Sprediķu grāmatas 2. dalas, kur līdzās ir pat vairāki reduplikatīvie verbālie savienojumi ar divdabi - daru ko darīdams, iemu kur iedams, domāju ko domādams.

Taß Konings Dawid licka nokaut to Vriam / taß Darrbs tam Koninjam ghann krimmta to Śrrdi / ka Wings patz śacka: Manni Ghräki gir allafch preekfch mann / ghribbädams śatziet / E $\beta$ darru ko darridams / E $\beta$ eemu kur eedams / E $\beta$ dohmaju ko dohmadams / allafch E $\beta$ fchkeetoh $\beta$ preekfch śaweem Atzeem rädfoht / ka us mannu Wahrdu / us mannu Pawehleśchanu taß Vrias / katters ghohdiegs Zillwähx by / tohp nokautz. (Manc1654_LP2, 11710-11) 


\subsection{Adverbi}

Darbības pastiprinājums tiek panākts, arī pievienojot verba personu formai tās pašas saknes adverbu vai adverbējušās formas ar -tin un -in. Ar adverbu sastopami, piemēram, reduplikatīvie vārdu savienojumi jāšos iejāj, tecinus tek. Piemēram,

\section{jāšos iejāj}

Bett no to Ölje=Kallnu lieds patt Jerufalemes nhe ghribb wings kahjam eet / bett jahfchoh $\boldsymbol{\beta}$ ee=jah. (Manc1654_LP1, 419) tecingus tecēja

.. bett tee wairoja ick briefchi ick Stundas śawus Ghräkus / und tetzinus tetzeja tee ka Ackli Laudis eekfchan Deewa Dußmibu und Śohdibu. (Manc1654_LP2, 19011)

Ļoti raksturīgs pastiprinājuma līdzeklis sprediķos ir reduplikatīvais vārdpāris - verbs un adverbs ar -in vai -tin. G. Mancelis šo līdzekli izmanto loti bieži. Vairākas reizes sastopams vārdu savienojums diltin nodils, kā arī lìtin lìt, lietin izliet (apliet), sūcin izsūc, audzin aug, sietin sasien, dedzin deg (dedze), lūstin lūst, spiestin spiests (iespiest), bēgtin bēg, rautin izrauts, urbtin ieurbt, racin ieracis, rūdzin rūgst, sarcīn nosarkst, lūdzin lūdz, kusin kūst. Bieži vien šis vārdu savienojums lietots ar saikli $k \bar{a}$ priekšā, norādot uz šksietamu salīdzinājumu. Piemēram,

\section{audzin aug}

Vnd räds arr śaweems Atzeems / ka ar leelu Brienumu ta Maife Rohkahß turroht audfinn augh / und pehtz wairahk att=leek / nhe ka pirmahk bijis. (Manc1654_LP1, 3352)

\section{diltin nodils}

.. und tee Zillwäki dilltin nodills / ifśabidamees / und ghaididami tahß leetas / kattri nahx us Semmes. (Manc1654_LP1, 14 $1_{12}$ ) sūcin izsūc

Zitts leelu Ghohdu py Kungheems meckladams / ka śuhzin iß =śuhz ohtru / dfänn par Warru / und darra śawam Tuwakam nhe $=$ patteef'se. (Manc1654_LP1, 2939)

\section{lietin izlējis}

Ko palieds tad mums / ka Chriftus tick dauds unnd ar tahdahm leelahm Śahpehm / unnd ghruhtahm Mohkahm śawas śwähtas Afśsinis nhe ißpillinaji $\beta$ / bett leetin=ißlehji $\beta$ gir?

(Manc1654_LP3, 1135)

\section{lūstin lūst}

Vnd tomähr kad Deewam śohdiet buhß tohß Beßdeewighus / tad Winjam Śirrds par to ka luhftinn luhft / und JEfus Chriftus śawas 
ghaufchas Af'śaras rittina / kad winjam tohß Beßdeewighus Juddus śohdiet buhß. (Manc1654_LP2, 77 28 )

\section{lūdzin lūdz}

Oho! Ka fkubbena taß tad / winjam prettie eet / und beß Mittefchanas / weenu mähr luhdfin luhds / ka tam Nhewefśelam warrätu paliedfehtz tapt. (Manc1654_LP2, 358\{338\}28)

\section{urbtin ieurbti kluva}

Zeek nu Ghalli tanny Krohny by / teek zaurumi Winja śwähta Ghallwa' / und kurr irr winja jauku Waighu aißjehme / ka urrbtin eeurrbti klua / tah attkall pa pillam Afśinis no Ghallwas und Waighu iß=tätzenaja. (Manc1654_LP3, 110)

\section{rautin top izrauts}

Bett redfi / kaß Deewam padodahß / śawu Dwehfśel JEfu Chrifto / śawam Peftitajam pawehl / taß ka rautinn tohp ißrautz no wifśenadam Bädahm. (Manc1654_LP2, 277\{257\} 17)

\section{kusin kust}

Tapehtz rädfädams śawu Maht ar to Mahzekli Jahni leelah $\beta$ Bähdahß und Nofkumfchana` ftahwofchu / śahk Winjam tha Śirrds ka kufśinn kuft no leelas Mieläftibas prett Maht / usrunna to nhe ar dauds Wahrdeem / bett kattri itt py Śirrds peelippa: Śeewa / ( śacka Wings ) redfi / taß gir taws Dähls. (Manc1654_LP3, 1732-3) dedzin dedze

Kad Deews śacka: Töw nhe buhß nokaut / fchkitta tee Warifeer̦i / kad winji ar Rohku nhenokahwe zittu Zillwäku / tad nhe by tee pahrkahpuśchi ścho Deewa Baußlu / jebfche teem ta Śirrds no leeleem Dußmeem dedfin dedfe.. (Manc1654_LP2, 114 $4_{30}$ )

\section{sarcīn no=sarkst}

..daffch wahrtahß fahle / und ghohfahß Śauleh / daśch pliete und dferr / daśch to Laiku kahwädams śchurrp und turrp ftaigha / daśch ghawile / und dfeed kahdas dfeeßmas / ka ghohdiegs Zilllwähx śarrtzien no=śarrgft klauśidams.

(Manc1654_LP2, 303\{283\}18-19)

Arturs Ozols šādus un līdzīgus teicienus detalizēti aplūkojis savā grāmatā „Latviešu tautasdziesmu valoda“, pieskaitot tos pie verbālās tautoloǵijas. Savukārt tipisks apakštips - adverbiāli verbālā tautolog̣ija, pie kuras pieder adverbi ar -in, -tin, - ir produktīvākais tautologiijas veids tautasdziesmās (Ozols 1993, 401). Ozols min piemērus - Kam tos miežus plāvin plāoa... Kam to alu dzertin dzêra... Tā ka acīmredzot šāds modelis ticis aktīvi lietots tautas valodā, tautas dziesmās, un G. Mancelis to ir ievērojis un izmantojis. 


\subsection{Reduplikatīvie vārdu savienojumi ar -šana}

G. Manceḷa sprediķiem visraksturīgākais verbālais reduplikatīvais vārdu savienojums ir verba (vai attiecīgā divdabja) savienojums ar tās pašas saknes substantīvu ar izskaņu -šana, turklāt visos gadījumos arī savienojumā ar adjektīvu liels, resp., liela. Atvasinājumam ar -šana šajos teicienos nav svarīga leksiskā nozīme, bet tas pastiprina attiecīgo verbu, bieži vien izsakot ilgstošu nepārtrauktu darbïbu. G. Mancela tekstos ir sastopami teicieni lielu brēkšanu brēc, lielu gulēšanu gul, lielu lēkšanu lec, lielu pilēšanu pil, lielu vilkšanu velk, lielu steigšanu steigdamies, lielu krākšanu krāc, lielu paciešanu cieš, lielu priecāšanu priecājas, lielu tvīkšanu tvīkst, lielu lūgšanu nolūgt, lielu spiešanu spiest, lielu saukšanu sauc. Piemēram,

lielu brēkšanu brēce

Bett tee L̦audis / kattri preekfcha ghaja und packal ftaighaja /

leelo Brehkfchane brehze / und śatzija: Hofianna tam Dahwida

Dählam .. (Manc1654_LP1, 1020)

\section{lielu steigšanu steigdamies}

Attftahdami śawus Lohpus us Lauku / leelo Steikfchano

fteikdameeß wifśi no=eet us Bettlehem / und attrohd wifśas Leetas tha / ka Deews zaur śawu Engheli teem Ghanneem litzis śatziet.

(Manc1654_LP1, 61 28)

\section{lielu krākšanu krākt}

Nhe buhß śchinnieß Laikohß eekfchan Ghräkeem apśnauft / apmickt / und leelu krahkfchanu krahkt / bett mohdrigheem buhß mums buht. (Manc1654_LP1, 24 30 )

\section{lielu lēkšanu lēce}

.. kad Elifabeth to Śweizenaśchanu Mariae dfirrdeja / leelo

Lehkśchano lehze taß Bährns tahß Elifabeth / śawas Mahtes

Meefśahß buhdams. (Manc1654_LP2, 879)

\section{lielu spiešanu spiest}

Deews .. pawehl śaweem Kallpeem / nhe ween toh $\beta$ Weefśis aizenaht / bett tohß leelo Speeśchano fpeeft śawa` Namma` nahkt / ka taß pills taptu. (Manc1654_LP2, 359-10)

lielu priecāšanu .. priecājāas

Leelo Preezaśchano Wings taggad preezajah $\boldsymbol{\beta}$ / ka winja ghruhtas Mohkas / und Nahwe nhe gir wellte muhf'so dehl zeefta .. (Manc1654_LP2, 6722)

\section{lielu tvīkšanu tvīkst}

Redfi Manns Draugs / ka tam Kungham JEfu Chrifto leelo

Twiekfchano twiext pehtz muhf'śas Dwehfśeles.

(Manc1654_LP2, 19410) 
Lielākoties atvasinājums ar -šana un adjektīvs lietots akuzatīvā - lielu, bet dažkārt šajos teicienos izmantota arī lokatīva forma - lielā gaidīšanā gaidījuši, lielà lūgšanā lūgdams, lielā pievilšanā pievilt, lielā lēkšanā lec, rej lielā riešanā, lielā kliegšanā kliedz, lielā brēkšanā brēc. Piemēram,

liela gaidīšanā gaidījuši

.. śchy gir tha Deena / us kattras leela'Ghaidieśchana`

ghaidijuśchi gir tee śwähti wätzi Tähwi / Proweetes und Koninji .. (Manc1654_LP1, 35513-14)

\section{lielā pievilšanā pievilti}

Redfeeta / ścheit gir C H R J S T VS / jeb turr / tad nhe buhß jums to titzeht / aifto nhe=ustitzami Chrifti / unh nhe $=$ ustitzami Prowetes ißdohfśeeß / und leelas Siemes und Brienumus darrieß / ka arridfan tee Jßrädfäti .. leela`Peewillfchana` peewillti taptu. (Manc1654_LP2, 406\{486\}11-12)

\section{lielā lēkšanā lec, rej lielā riešanā}

Ja / tawa Śirrds no leelas Liexmibas töw Leela`Lehkśchana`lätz / kad tu ee=ghadajeeß / kahdu Blehdibu tu darrijis. Teekam Durris ais=flähkta $\beta$ und wif'śur kluß gir / ghull taß Śunns ; bett tudehl kad kaß labba py Durrihm klaudfena / usmohft taß Śunns / rey lela Reeśchana / lätz arri us śweffchu Zillwäku. (Manc1654_LP3, 128 7-8; 14)

Domājams, ka šie teicieni lielā mērā ir G. Manceḷa daiḷrades darinājumi. Meklējot, vai šādi reduplikatīvie vārdu savienojumi ar -šana atrodami arī tautasdziesmās, izdevās atrast tikai vienu piemēru: Brauc' ar vienu braukuminu / Rīgā jūgtu kumeliņu; / Dzied ar vienu dziedāšanu / Vakarēju sākumiņu. Turklāt šīs tautasdziesmas variantos nav izmantots atvasinājums ar -šana, bet gan, piemēram, dzied ar vienu dziedājumu.

Savukārt folklorā, daiḷliteratūrā ir sastopami līdzīgi izteicieni ar viens un atvasinājumu ar -šana lokatīvā - iet vienā iešanā, runā vienā runāšanā 'runāt vienā laidā' u. c., šādus teicienus bieži lieto arī runātajā valodā. Mīlenbaha un Endzelīna vārdnīcā pie vārda iet minēts arī teiciens iet vienā iešanā (ME II, 80-81). Vārds iešana kopā ar apzīmētāju viens pastiprina vārdu iet: vingš iet vienā iešanā 'viņš iet visu laiku vienā laidā'. Savukārt G. Mancelim visur lietots apzīmētājs liels, tā ka, domājams, viņš pielicis roku pie šo teicienu darināšanas. Jāpiebilst, ka atvasinājumi ar -šana, kas, kā zināms, agrīnajos tekstos lietoti gana daudz, ir šim mērķim pateicīgs materiāls, jo tie atvasināmi no visiem verbiem, un šiem substantīviem visvairāk izpaužas verba daba, tie apzīmē pašu darbību. Jāpiezīmē arī tas, ka G. Mancelis šādus teicienus ir minējis savā vārdnīcā „Lettus“, kā arī „Phraseologia Lettica“, tā ka tie droši 
vien ir arī dzirdēti runātajā valodā. Piemēram, lielu virdēšanu verd, lielu smiešanu smieties:

leelo wirrdeschano wärrd jeb wirrden wärrd

(Manc1638_PhL 300);

leelu śmeeschanu śmeeteeß - laut oder vber die maß lachen

(Manc1638_L 110).

Zīmīgi, ka teicienam lielu smiešanu smieties vācu valodā nav minēts atbilstošs teiciens, bet gan tas tulkots skaidrojoši - 'skaļi vai pār mēru smieties'.

\subsection{Citi verbālie reduplikatīvie vārdu savienojumi}

Verba nozīme tiek pastiprināta arī tad, ja tā formai seko tās pašas saknes adverbējies lokatīvs, piemēram, tūkt tūkumā, augt augumā. Šim lokatīvam ir stilistiska nozìme, un tas tiek dēvēts arī par tēlojamo lokatīvu (MLLVG 407-408).

\section{tūka tūkumā}

Tahß eekfchas Winjam tuhka tuhkuma' / und by winjam

ghaufchas Wähdäro=ghraifas. (Manc1654_LP1, 10727)

\section{aug augumā}

.. teekam tu patz weens ar tawahm Bähdahm und Śirrds=Raifu

kaujeeß / teekam tawas Śirrds=Śahpes augh aughuma ..

(Manc1654_LP3, 131 14 )

Reduplikatīvs verbāls vārdu savienojums G. Mancelim ir arī gribiet negribiet 'gribat vai negribat', kas tieši šādā formā lietots vairākas reizes. Tekstā tas ir kā iesprausts teiciens.

\section{gribiet ne gribiet}

.. und kad Wings tam Wällam pa=wehl / tam buhß śawu zellu

Elles dibbina` eet / tad buhß tam / ghribbiet nhe ghribbiet / tudell behgt / und to Zillwäku ar Meeru lickt. (Manc1654_LP1, 3122)

Līdz̄̄gs ir arī verbālais vārdu savienojums zinot nezinot.

.. tanny Naśta` gir wifśsi darriti Ghräki / kattri prett Deewa

Wahrdu / ar Dohmahm / Wahrdeem un Darrbeem ghräkohti gir / und ick=deenas / ick=ftundas / ick=Atzomirrcklohß / fiñoht nhefinnoht noteek / ar Nhetitzibu / Nheklauśiśchanu / Deewa Wahrda wellta=Wallkośchanu. (Manc1654_LP3, 21 2-3)

G. Manceḷa Sprediķu grāmatā nereti sastopami teikumi, kurus nevar pieskaitīt pie kāda no reduplikācijas veidiem, bet tie ir interesanti no vārddarināšanas viedokḷa - tajos atkārtojas viena celma vārdi, kas pieder pie vienas vārddarināšanas ligzdas. Šeit tiem nav pastiprinājuma nozīmes, bet tie demonstrē vārdu darināšanas k̦ēdi. Piemēram, sēt $>$ sējejejs, sēkla; mācīt(ies) > mācība, mācètājjs; mērs > mērot > izmērot, iemērot. 
sèjējs .. sēelklu sēt

Weens Śehjeis ißghaja / śacka taß Kungs JEfus Chriftus / śawu

Śähklu śeht. (Manc1654_LP1, 25916-17)

mācētāju .. māāibu mācīties

Tha arridfan no willtighu Mahzetaju nhe warram meh $\beta$ labbu

Mahzibu mahziteeß. (Manc1654_LP2, 1503-4)

mēru .. izmēerosieta .. iemērots

Aifto ar to Mähru / ar kattru juhß ißmehrofśeeta / taps jums

attkal ee =mehrohtz. $($ Manc1654_LP2, 71 15-16)

\section{Nobeigums}

Reduplikācija kā stilistikas līdzeklis, resp., dažādu veidu atkārtojumi, G. Mancel̦a sprediksos ir bieži sastopami.

No piemēriem redzams, ka G. Mancelis izmantojis reduplikāciju, dažādu tipu vārdu savienojumus, kā stilistisku, ekspresīvu līdzekli, un domājams, ka tie ir latviešu valodai raksturīgi un noklausīti runātā valodā vai tautas dziesmās (īpaši vārdu savienojumi ar adverbu -in), par ko liecina arī piemēri G. Manceḷa vārdnīcā.

Jāpiemin, ka dažādi reduplikatīvie savienojumi sastopami arī citā 17. gadsimta vārdnīcā - Georga Elgera poḷu-latīṇu-latviešu vārdnīcā. Piemēram, vārdnīcā ir teicieni snidzin snig (Elg1683_DPLL, 507), Es lejan lej (Elg1683_DPLL, 514), Es trīsin trīse, Es drebin drebe (Elg1683_DPLL, 550), Es mirdzin mirdzu (Elg1683_DPLL, 664), lai gan ne poḷu, ne latīṇu valodā šajā vārdnīcā nav līdzīgu vārdu savienojumu, kas liktu domāt, ka būtu šādi jātulko. Turklāt, domājams, poḷu valodā reduplikācijas parādība nemaz nav raksturīga.

Jāpiezīmē, ka vairāki G. Manceḷa sprediķos sastopamie stabilie vārdu savienojumi tiek lietoti relig̣iskajos tekstos līdz mūsu dienām, piemēram, viens vien̄̄gs [Dievs] vai mūžĭgi mūžos, kas ir Tēvreizes sastāvdaḷa. Protams, tie tiek lietoti kā stabili veidojumi, kā formulas, un neviens, tos lietojot, nedomā par to, ka tā būtu reduplikācija, resp., stilistisks paņēmiens. Kā jau minēts, literatūrā uzsvērts, ka šādus paņēmienus nereti izmanto oratori. Tā kā spredikịis pēc savas būtības sākotnēji ir runāts teksts, tad tas arī varētu būt saistîts ar dažādo stilistisko līdzekḷu izmantojumu. Protams, jāṇem vērā, ka G. Manceḷa sprediķos izmantots reliğiskās retorikas stils, patētiska valoda, didaktisks piegājiens, līdz ar to šādi stilistiski līdzekḷi ļ̣oti labi iederas. Arī atkārtojumi, kas tiek lietoti, uzsverot domu. Šãdi stilistiskie līdzekḷi ir raksturīgi arī vēlāku periodu latviešu daiḷliteratūrā (atšksirībā no parastiem tekstiem). 
Nobeigumā teikums, kurā prasmīgi apvienoti vairāki reduplikācijas veidi.

Ar to Mähru ka juhß efśeeta iß=mehrojuśchi / ta taps jums muhfcho mufcham ar Kaudfo Kaudfem ee=mehŗohts. (Manc1654_LP2, 429\{409\}3-4)

\section{Secinājumi}

1. G. Manceḷa sprediķos bieži kā stilistisks līdzeklis sastopama reduplikācija, dažādu veidu atkārtojumi, nominatīvie, adverbiālie un verbālie reduplikatīvie savienojumi, kas vienlīdz bieži lietoti visās trijās Sprediķu grāmatas dạ̧ās.

2. Visvairāk sastopami verbālie reduplikatīvie vārdu savienojumi, kur verbu papildina tās pašas saknes substantīvs ar -šana, nenoteiksme, divdabis vai adverbs. Savukārt no šiem savienojumiem G. Manceḷa sprediķos visbiežāk lietoti reduplikatīvie vārdu savienojumi ar -šana, kā arī ar adverbiem -in un -tin.

3. Substantīvus visbiežāk pastiprina ar tā paša celma substantīvu g̊enitīvā, resp., pastiprinājuma genitīvu.

4. Dažādu reduplikācijas veidu izmantojums G. Manceḷa tekstos saistāms gan ar latviešu folkloras, gan ar sarunvalodas ietekmi.

5. G. Manceḷa tekstos lietotie stabilie vārdu savienojumi ir raksturīgi latviešu relig̣iskajos tekstos līdz mūsu dienām.

6. Šādu tautas valodā raksturīgu reduplikatīvo teicienu lietojums G. Manceḷa sprediķos liecina par to, ka G. Mancelis ir labi pratis latviešu valodu, dzīvojot latviešu vidē, ieklausījies apkārt skanošajā tautas valodā.

\section{Avoti}

Manc1638_L =

Manc1638_PhL =

Manc1654_LP1 =

Manc1654_LP2 =

Manc1654_LP3 =

Elg1683_DPLL =
Mancelius, Georgius. Lettus das ist Wortbuch. Sampt angehengtem täglichem Gebrauch der Lettischen Sprache. 1638.

Mancelius, Georgius. Phraseologia Lettica. 1638.

Mancelius, Georgius. Lang=gewünschte Lettische Postill I. 1654.

Mancelius, Georgius. Lang=gewünschte Lettische Postill II. 1654.

Mancelius, Georgius. Lettische Lang=gewünschte Postill III. 1654. Pieejami: http://www.korpuss.lv/senie/.

Elger, Georgius. Dictionarium Polono-Latino-Lottauicum: Opus Posthumum. In gratiam Studiosae Iuuentutis. In lucem datum. Vilnae: Typis Academicis Soc. IESU. 1683. 


\section{Literatūra}

Ahero, Antonija. 1955.

Apīnis, Aleksejs. 1993.

Baltiņa, Maija. 1994.

Bērziņš̌, Ludis. 1940.

Bērziņš̌, Ludis. 1944.

Endzelīns, Jānis. 1951.

Grudule, Māra. 2014.

Krēsliņš, Jānis. 1992.

$\mathrm{LFV}=$

$\mathrm{LVG}=$

$\mathrm{ME}=$

MLLVG $=$

Nīinna, Daina. 2014 [2000].

Ozols, Arturs. 1993.

Štekauer, Pavol, Salvador

Valera, Lívia Körtvélyessy. 2015.

VPSV $=$

Anna Frīdenberga

Latvijas Universtātes

Latviešu valodas institūts

Akadēmijas laukums 1

LV-1050, Rīga, Latvija

anna_f@inbox.lv
Galvenie salikto īpašības vārdu veidi mūsdienu latviešu valodā. LPSR ZA Valodas un literatūras institūta raksti. V. Rīga: LPSR ZA izdevniecība, 37-85.

Georgs Mancelis, izglīitiba, grāmata. Varavīksne 1993. Rīga: Preses nams, 175-183.

Mancelis un viña sprediki. Atcerei un ierosmei. Celšs. Teoloğisks un kultūrvēsturisks žurnāls. Nr. 1 (45). Rīga: Latvijas Universitāte, 56-60.

Ievads latviešu tautas dzejā. Rīga: Latvijas Universitāte.

Valoda un izteiksme Manceḷa rakstos. Izglîtības Mēnešraksts. Nr. 1. Rīga: Izglīīibas un kultūras ǵenerāldirekcijas Mācības līdzekḷu nodaḷa, 8-12.

Latviešu valodas gramatika. Rīga: Latvijas Valsts izdevniecība.

Par K. Fīrekera (17. gs.) tulkoto dziesmu valodisko vērtību. Deminutīvi, reduplikācija, sinonīmija. Valodas prakse: vērojumi un ieteikumi. 9. Rīga: Latviešu valodas ağentūra, 20-34.

Dominus narrabit in scriptura populorum: a Study of Early Seventeenth-Century Lutheran Teaching and the Lettische lang-gewünschte Postill of Georgius Mancelius. Wiesbaden: O. Harrassowitz. Laua, Alise, Aija Ezeriņa, Silvija Veinberga. Latviešu frazeolog̣ijas vārdnīca. 2000. Rīga: Avots.

Latviešu valodas gramatika. 2013. Rīga: LU Latviešu valodas institūts.

Mīlenbahs, Kārlis. Latviešu valodas vārdnīca. I-IV. Redig̣ējis, papildinājis, turpinājis J. Endzelīns. Rīga: Izglītības ministrija, 1923-1932.

Mūsdienu latviešu literārās valodas gramatika. 1959. I sēj. Fonētika un morfolog̣ija. Atb. red. E. Sokols. Rīga: Latvijas PSR Zinātņu akadēmijas izdevniecība.

Reduplikācija latviešu valodā. Ne tikai gramatika. Rīga: LU Latviešu valodas institūts, 197-201.

Latviešu tautasdziesmu valoda. Rīga: Zvaigzne.

Word-formation in the World's Languages. A Typological Survey. Cambridge: Cambridge University Press.

Valodniecības pamatterminu skaidrojošā vārdnīca. 2007. Rīga: Valsts valodas ağentūra. 


\section{SUMMARY}

\section{Reduplication in the Book of Sermons (1654) of Georg Mancelius}

\section{Anna FRĪDENBERGA}

In Latvian reduplication as a repetition of word root, stem, or entire word is used to express intensification. The phenomenon of reduplication has been studied as a stylistic means of expression often used in fiction and in folklore.

In the article different types of reduplication are studied in „Lang-gewünschte Lettische Postill“ (1654) or the Book of Sermons of Georg Mancelius. The Book of Sermons is the first original writing in Latvian. The sermons are based on methods of religious rhetoric, figurative language, colourful expression and the use of various stylistic means, including reduplication, is characteristic. Reduplication - different repetitions, nominal, adverbial, and verbal reduplicative word groups are often used in the sermons of G. Mancelius. In nominal word groups most often the so called intensive genitive is used to intensify the noun, for example, drusku=druskās, pissșlu=pišl los, pelnu=pelnos, malu=mali. Adverbial reduplicative word groups, for example, $k \bar{a} r t=k \bar{a} r t i m$, tieš=tiešam, pār $=$ ārim, are also characteristic in the sermons. However, most often reduplicative verbal word groups are used - the verb is intensified by the same root noun, by an adverb, as well as by a participle or infinitive. Reduplicative word groups with the adverbs -in and -tin are very characteristic, for example, audzin aug, lūstin lūst, rūdzin rügst. Such expressions are very often used in Latvian folk-songs. Supposedly, such a pattern was frequently used also in colloquial speech and G. Mancelius had noticed and used it. Very frequently used are word groups, where the verb is intensified by a noun in -šana, for example, lielu krākšanu krāc, lielu tvīkšanu tvīkst, lielā lëkšanā lec. The extensive use of different reduplicative word groups in the sermons of G. Mancelius could be connected both to the influence of Latvian folklore and colloquial speech. So it presents evidence that G. Mancelius knew Latvian well, as well as listened attentively to the language spoken around him. 


\title{
RUSIJA „LIETUVIỤ KALBOS ŽODYNO“ ILIUSTRACINIUOSE SAKINIUOSE IR REIKŠMIŲ APIBRĖŽTYSE
}

\author{
Aurelija GRITÉNIENÉ \\ Lietuviu kalbos institutas
}

\section{Ivadas}

Didysis „Lietuvių kalbos žodynas“ (toliau tekste LKŽe) - 100 metų rašytas didžiausias lietuvių kalbotyros veikalas, kurị pagrịstai galime vadinti savotišku lietuvių tautos epu. İ ši žodyną galima žvelgti kaip ị įvairialypi tekstyną, kuriam medžiaga buvo renkama iš 445 rašytinių ir rankraštinių šaltinių ir 492 vietovių iš visų lietuvių kalbos tarmių. LKŽe nuo kitų lietuvių kalbos aiškinamųjų žodynų skiriasi savo apimtimi, istoriškumu ir tarminès medžiagos gausa. Būtent dèl to šis žodynas laikomas vienu svarbiausių XX a. pirmosios pusès lietuvių kultūros tekstų. Tai unikalus šaltinis, teikiantis daugybę galimybių bei impulsų naujoms įžvalgoms (Zabarskaitė 2012: 241). Ne veltui žodynai (taip pat tautosakos rinkiniai, istoriografiniai veikalai) laikomi tautos požymių kompendiumais (Subačius 1999: 34).

Remiantis akademinio žodyno kaip ịvarialypio tekstyno medžiaga jau ištirtas lietuviu politinis pasaulėvaizdis (valstybè, įstatymas, valdžia), pasitelkus žodyne fiksuotą Adalberto Bezzenbergerio medžiagą, aprašytos marios, pamarys ir pamariškis (Zabarskaite 2010: 126tt; 2012: 239tt); nagrinètas šermukšnio ir žodyno vaizdinys (Gritenienè 2016: 85tt; 2017: 1tt); tirta, kokia terminologinè informacija atrinkta žodynui, ką sako iliustraciniai pavyzdžiai terminologijos klausimais (Umbrasas 2019: 162tt).

Šio straipsnio tikslas - ištirti, koks RUSIJOS konceptas susidèlioja iš LKŽe iliustracinių sakinių ir reikšmių apibrèžčių, kuriose minima leksema Rusija, nustatyti, kurie koncepto požymiai yra svarbiausi, ryškiausi ${ }^{1}$ ir kokia galètų būti Rusijos kognityvinè definicija². Siekiant ịgvendinti pagrindini

1 Konceptas - tai vaizdinys, iškylantis mūsų sąmoneje išgirdus ar pamačius parašytą žodị. Jis suvokiamas kaip esminis pažintinis žinių vienetas, priklausantis žmogaus konceptualiajai sistemai ir kylantis iš patirties - tai yra visa informacija apie ką nors, esanti žmonių, kalbančių tam tikra kalba, sąmonèje (plačiau žr. Papaurèlytė-Klovienė 2007: 17; Gudavičius 2011: 109tt; Smetonienè 2019: 131).

2 Kognityvinė definicija veikia kaip metodas stereotipams ir jų vidinei struktūrai aprašyti. Ji remiasi kasdieniu, asmeniniu pasaulio pažinimu ir patyrimu; ja siekiama parodyti, kokių asociaciju kyla kalbėtojo sąmonejje tam tikroje kalbinejje situacijoje (Bartmiński 2007: 44; Gudavičius 2009: 70tt; Rutkovska, Smetona, Smetonienè 2017: 30; Smetonienè 2019: 132). 
tyrimo tikslą, iškelti keli konkretūs uždaviniai: ištyrus surinktą medžiagą semantinès analizès, interpretaciniu ir aprašomuoju metodais, apibūdinti Rusijos svarbiausius įvykius, ekonomiką, ūkį, ryšĭ su Lietuva, aptarti šalyje gyvavusias idejjas, partijas, socialines grupes, žmonių ir tautų padètị, apibūdinti šalies gamtą, mokslą ir meną. Straipsnyje analizuojami ne žodžių tarpusavio santykiai junginyje ir ne atskiri žodžiu junginiai, o žiūrima, kokia svarbi konceptuali informacija pasakoma visu sakiniu, kai per konkretaus žodžio semantiką ir ryšius su kitais žodžiais, reikšmėmis, konotacijomis, asociacijų semantinius mechanizmus sukuriama aukščiausia kalbos suvokimo pakopa - prasmè, kartu su ja ir ideologinè implikacija, daranti įtaką tam tikro objekto vertinimui (plg. Zabarskaite 2019: 76tt). Taigi straipsnyje laikantis kognityvinio požiūrio bandoma nustatyti, kaip kalbos vartotojų sąmonejje verbalizuojamas RUSIJOS konceptas.

Tyrimui toks konceptas pasirinktas tikslingai. Lietuvos valstybė įsikūrusi teritorijoje, kurioje susikerta Rytu ir Vakarų interesų sferos, tad akivaizdu, kad bene didžiausią įtaką Lietuvos ,politiniam ir kultūriniam gyvenimui, jos valstybingumo raidai nuo XV a. pabaigos dare rytų kaimynè - Maskvos kunigaikštystė, vẻliau carinė Rusija, o nuo XX a. Sovietų Sąjunga“ (Burinskaitė 2005: 9). Net ir subyrëjus šiai sąjungai, Vakarai (tame tarpe ir Lietuva) negali apsieiti be Rusijos. Šiandienos istorikai ne veltui šią valstybę vadina imperija, teigdami, kad imperijos, valdè ir valdys pasauli, o Rusija šiame „,imperijų koncerte" užima svarbią, esminę vietą (Nowak 2015: 285). Kalbininkai jau yra ištyrę ir aprašę Rusijos federacijos prezidento Vladimiro Putino naratyvų ideologinius mechanizmus Lietuvos internetinèje žiniasklaidoje (Zabarskaitė 2019: 76tt), ne mažiau įdomu pasižiūrèti, kokią vietą pati Rusija užima lietuvio pasaulèvaizdyje, koks jos paveikslas susidèlioja akademinio žodyno kontekste, kuriame sutelktas pasaulis Lietuvoje ir Lietuva visame pasaulyje (Nepokupnas 2002: 1421).

Straipsnyje išanalizavus vieno konkretaus žodžio (ir jo sinonimų) vartoseną taip pat bandoma nustatyti, ar yra (ne)paslèptos ideologijos LKŽe diskurse. Skaitant akademinį žodyną būtina nepamiršti, kad sovietinès okupacijos metu jis neišvenge to meto režimo primestos sovietinès cenzūros bei ideologinio kišimosi ị žodyno turinį. 1947 m. išẻjus Juozo Balčikonio redaguotam II žodyno tomui po metų spaudoje pasirodè žodynininko (vèliau - vieno iš vyriausiųiu žodyno redaktorių) Jono Kruopo recenzija, kurioje jis, prisitaikydama prie to meto aplinkybių, teigè, kad ,žodynas negali būti apolitiškas ir beidejiiškas. Jis, kaip ir kiekvienas tarybinis mokslo veikalas, turi turèti vieną pagrindinį tikslą - tarnauti liaudžiai, prisidèti prie visuomenès komunistinio auklejimo, prie buržuazinių liekanų iš žmonių sąmonès išgyvendinimo“ (Kruopas 1948: 45). 
Po daugelio metų buvęs Lietuvių kalbos ir literatūros instituto direktorius prisiminè, kad anuo metu šis J. Balčikonio redaguotas tomas „sukèlė dideli nepasitenkinimą partijos Centro komitete, tomas buvo išimtas iš apyvartos ir sunaikintas, išlikę egzemplioriai tapo bibliografine retenybe“ (Žukas 2005: 56). Taigi I ir II tomai buvo „perrašyti“ pagal sovietinių mokslo ideologu modelį․ Buvo siekiama, kad žodynas taptų socialistinès sąmonès įtvirtinimo pagrindu, tarnautų liaudžiai, prisidètų prie socializmo statybos ir komunistinio visuomenès auklèjimo, todèl nuo trečio tomo buvo pakeista žodyno rašymo instrukcija ${ }^{4}$, pirmieji du tomai paslèpti specfonde (Tamulionienè 2003: 63; Zabarskaitė 2010: 127). Net 14 žodyno tomų buvo leidžiami sovietų okupacijos metais, XV tomas išejo $1991 \mathrm{~m}$., tad jis mažiau paveiktas sovietinès ideologijos, „nuo XVI tomo žodyne sumažèjo ideologinès medžiagos, o po nepriklausomybės atkūrimo jos visai nebeliko" (Zabarskaitė 2010: 128). Taigi didžioji dalis žodyno buvo cenzūruojama pagal griežtą ideologinį modelį, kelis dešimtmečius sakiniai iš įvairių rašytinių šaltinių ir gyvų istorijos liudininkų buvo renkami ir užrašomi veikiant (savi)cenzūrai, kuri vykdė sovietizaciją ir nepageidaujamą realybę keitė dirbtinai sukonstruota. Nors žodyne rasime nemažai socialistinei sąmonei ugdyti ir ịtvirtinti skirtų iliustracijų, žymimų santrumpa sov. ${ }^{5}$, vis tiek negalime paneigti fakto, kad net ir anuomet „mokslui buvo svarbiausi tarmių ir senųjų tekstų faktai, gyvi sakiniai, ryškinę tautos gyvenimą, mąstymą“ (Vitkauskas 2002: 11). Autentiška žodyno medžiaga atspindi to laikotarpio žmonių jausmus ir mąstymą bei patvirtina mintį, kad žodyną „galima skaityti ir kitaip“ (Zabarskaitė 2012: 241), kaip populiaru istorijos vadovèlį, kuriame išryškejja ne tik istorinis kontekstas, bet ir atitinkamo meto įvykiai, dramos, veikejjai, draugai ir priešai.

3 I ir II žodyno tomų iliustraciniuose sakiniuose Rusija paminèta tik kartą, todèl atskirai peržiūrèti J. Balčikonio redaguotų tomų ir lyginti juos su perleistais sovietmečiu nèra prasmès.

41952 m. parengta žodyno rašymo ir redagavimo instrukcija buvo pildoma ir tikslinama ne kartą (ji perleista 1963 ir 1980 m.) ,atsižvelgiant ị tarybinès leksikografijos teoriją bei praktiką“" (LKŽ instrukcija 1980: 2).

5 Net 18 tyrimui atrinktų LKŽe iliustracinių sakinių turi pažymą sov. Ši pažyma ịvesta rengiant pirmą elektronini LKŽe variantą 2005 m. (vèliau žodynas atnaujintas 2008 ir 2018 m.). Kadangi žodynas buvo rengiamas septynis dešimtmečius, per tą laiką ne kartą keitėsi žodyno sudarymo ir redagavimo principai, tačiau rengiant elektroninę žodyno versiją leksikografiniai straipsniai iš esmès nebuvo redaguojami ar kupiūruojami, ištaisytos tik didesnès pastebėtos antraštinių žodžių transponavimo klaidos, suvienodinti sutrumpinimai, peržiūrètas frazeologizmų pateikimas, adaptuoti leksikografinio pateikimo ir formos dalykai bei kt. Santrumpa sov. elektroninèje versijoje buvo pažymèti ryškiausi sovietizmai, sovietinès realijos (plačiau žr. Naktinienè 2012: 93), tačiau analizuojant tyrimui atrinktus pavyzdžius pastebèta, kad šios pažymos dar trūksta prie daugybès sovietiniu laikotarpiu užrašytų iliustracijų. 
Tiriamoji medžiaga buvo renkama iš $\mathrm{LKŽ} \mathrm{e}^{6}$ : atlikus žodyne detaliąją paiešką rasti 138 iliustraciniai sakiniai, kuriuose minima leksema Rusija ${ }^{7}$. LKŽe Rusija vadinama ir kitais vardais. Rasta 11 iliustracijų, kuriose minima Maskolija ${ }^{8}$, 14 sakinių pavartotas fonetinis Rusijos variantas Rosija ${ }^{9}$, užrašyta po 1 sakinị su Rasiejumi ir Rasieja ${ }^{10}$.

Medžiaga tyrimui rinkta iš LKŽe, neimant naujausių Papildymų ir Tarmių kartotekų duomenų, todèl būtina pabrèžti, kad straipsnyje gauti rezultatai atspindi RUSIJOS konceptą, susidèliojusį lietuvių pasaulèjautoje pradedant Spalio revoliucjos įvykiais ${ }^{11}$ ir baigiant Sovietų Sąjungos žlugimu ${ }^{12}$. Tokị pasirinkimą nulèmė pati žodyno medžiaga: iš senesnių rašytinių šaltinių sakinių su leksema Rusija LKŽe fiksuota visai nedaug (tik 27) ${ }^{13}$, o carinès Rusijos konceptas jau atskirai aprašytas ${ }^{14}$, todèl šiame straipsnyje išsamiau analizuojama, koks Rusijos vaizdinys susidèliojo lietuvių sąmonèje sovietinio laikotarpio kontekste.

Pirminiame medžiagos rinkimo etape iš viso tyrimui buvo atrinkti 165 iliustraciniai sakiniai, kuriuose minima Rusija, Rosija, Rasiejus, Rasieja ir Maskolija. Iš šios imties eliminuota 20 sakinių, kuriuose minima carinè Rusija, ir 27 sakiniai, išrašyti iš senesnių rašytinių šaltinių (XIX-XX a. pradžios). Taigi šiame straipsnyje iš viso analizuojama 118 sakinių, kurių turinys leidžia sudèlioti sovietmečiu lietuvių sąmonėje susiformavusį RUSIJOS konceptą.

${ }^{6}$ Medžiaga rinkta iš 2018 m. atnaujintos LKŽe versijos (žr. www.lkz.lt).

${ }^{7}$ I šią imtį neįtrauktos iliustracijos su leksema Rusia, nes tai istorinis rytų slavų žemių pavadinimas.

8 Iš 11 LKŽe rastų sakinių su Maskolija tik 1 užrašytas gyvojoje kalboje (Šãtėse), o likę 10 fiksuoti Simono Daukanto raštuose bei įvairiuose XIX a. rašytiniuose šaltiniuose: laikraščiuose „Aušra“, „Lietuviška Ceitunga“, „Tiesos prietelius“ ir kt. Maskolija paminèta ir vienoje reikšmès apibrèžtyje - apibrèžiant būdvardị maskolinis 'nuo Maskolijos pučiantis, rytinis (apie vèją)'.

${ }^{9}$ Rosija daugiausia paplitusi šiaurès žemaičių šnektose (apie Kuršénus, Luõkę, Endriejãvą, Raudénus, Šatès); po vieną kitą sakinį su šiuo variantu užrašyta iš pietų, rytų bei vakarų aukštaičių patarmių.

10 Šie variantai fiksuoti Drùskininkuose ir Nemenčinèje.

11 Toks atspirties taškas pasirinktas todèl, kad ši revoliucija laikoma Sovietų Sąungos susikūrimo proceso pradžia, nors oficialiai Sovietų Sąjunga buvo įkurta $1922 \mathrm{~m}$.

12 Primintina, kad dauguma LKŽe iliustracinių pavyzdžių surinkta maždaug iki XX a. vidurio (Zabarskaitė 2012: 247).

13 Daugiausia sakinių rasta šiuose šaltiniuose: „Aušroje“ (4), Vinco Kudirkos ir Antano Smetonos raštuose (po 3), Vinco Pietario ir Juozo Tumo-Vaižganto kūriniuose (po 2), laikraščiuose „Keleivis“, „Tiesos Prietelius“, „Vilniaus žinios“, „Tèvynės sargas“ (po 2), po 1 sakini užrašyta S. Daukanto, Antano Baranausko ir kt. raštuose.

14 Plačiau žr. Gritenene 2020: 273-283. 
Daugiausia apie Rusiją sovietiniu laikotarpiu buvo kalbama įvairiuose rašytiniuose šaltiniuose ${ }^{15}$ - LKŽe rasti 75 tokie sakiniai. Konkrečių rašytojų, mokslo, kultūros veikëjų raštuose rasti tik 9 sakiniai, kuriuose paminèta Rusija (3 sakiniai iš Gabrielès Petkevičaitės-Bitès veikalų, 2 iš Vinco MykolaičioPutino raštų, po 1 sakini fiksuota botaniko Jono Dagio, istoriko ir visuomenininko Petro Klimo, rašytoju Antano Vienuolio ir Ievos Simonaitytès kūriniuose). 6 sakiniai išrašyti iš spaudos: popieriniame žodyne santrumpa sp atsirado tik nuo XVI tomo, o vèliau, rengiant elektroninį žodyno leidimą, ja buvo pažymèti visi vèlesni XX a. periodiniai leidiniai ${ }^{16}$. Iki tol visa tarybinė spauda buvo žymima bendra santrumpa tsp, o ideologiškai svarbesni to meto laikraščiai ar žurnalai turejo savo atskiras santrumpas ${ }^{17} .8$ tyrimui reikalingos iliustracijos didžiajam žodynui buvo išrašytos iš įvairių enciklopedijų, žodynų ir chrestomatijų. Bendrą rš santrumpą turi 53 tyrimui atrinkti sakiniai. Iki XVI tomo marksizmo-leninizmo klasikų raštų vertimai buvo žymimi kaip atskiri šaltiniai rašant visą veikẻjo pavardę, pavyzdžiui, Engelsas, Marksas; šalia Vladimiro Lenino pavardès būdavo nurodomi jo veikalo leidimo metai ir puslapis; ryškiausių sovietinès propagandos skleidejų (rašytojų, visuomenininkų ir pan.) raštai žodyne turèjo atskiras santrumpas, pavyzdžiui, Aleksandras Gudaitis-Guzevičius (A. Gud-Guz), Vincas Kapsukas-Mickevičius (V. Kaps), Valerija Valsiūnienė (V. Vals), Juozas Žiugžda (J. Žiugž) ir kt. Nuo XVI tomo šių ideologinių veikejų pavardès iš žodyno santrumpų sąrašo dingo, jas pakeitė bendra rš santrumpa, vartojama ir elektroniniame žodyno variante ${ }^{18}$. Tarmèse fiksuoti tik 43 sakiniai, kuriuose minima Rusija ir jos sinonimai. Kadangi rašytiniuose šaltiniuose Rusija ir jos sinonimai minimi gerokai dažniau nei užrašytuose iš gyvosios kalbos, galètume teigti, kad LKŽe pirmiausia išryškejja i̇vairių rašto žmonių (publicistų, žurnalistų, rašytojų, politikų ir pan.), kultūros bei visuomenès veikèjų sudèliotas RUSIJOS konceptas.

Atskiros LKŽe iliustracijos autorius yra individualizuotas (iliustracinio sakinio pabaigoje nurodoma konkretaus asmens, iš kurio raštų imtas sakinys, pavardès santrumpa, pavyzdžiui, A. Vien, Pt, P. Klim ir kt.) arba anoniminis (tokių iliustracijų autorių slepia bendros rš, sp, LE, MLTE ir pan. santrumpos). Tačiau bendrąja prasme galime teigti, kad visą žodyno hipertekstą kūrẻ vienas

${ }^{15}$ Apie LKŽe šaltinius kaip kultūros istorijos atspindžius plačiau žr. Šimėnaite 2010: 158tt.

16 Pirmieji XIX a. lietuviški laikraščiai („Aušra“, „Lietuviška Ceitunga“ ir kt.) atskiras santrumpas turèjo visą laiką.

17 Kaip atskiri šaltiniai žodyne buvo išskirti „Komunisto“ ir „Tiesos“ leidiniai, jų pavadinimai sovietmečiu žodyno tekste net nebuvo trumpinami.

18 Kadangi medžiaga tyrimui buvo renkama iš elektroninès žodyno versijos (nes čia veikia įvairios automatinès paieškos), tai ir pačiame straipsnyje prie iliustracijų paliktos bendrosios santrumpos sp bei ršs, smulkiau nedetalizuojant, kokio tarybinio veikejjo pavardę jos paslëpè. 
kolektyvinis kūrejas - visa lietuvių tauta: įvairūs rašto, kultūros, visuomenès, politikos ir pan. veikejjai (jau minèti tiksliai įvardyti ir anoniminiai autoriai) bei tūkstančiai neįvardytų gyvosios kalbos informantų, kuriuos slepia konkrečių vietovių santrumpos.

\section{Rusija iliustraciniuose sakiniuose}

Iš iliustracinių sakinių ryškejja keli pagrindiniai RUSIJOS koncepto požymiai.

\subsection{Spalio revoliucijos atgarsiai}

Didelëje šalyje nuolat vyko visokių svarbių įvykių. Kartais iliustraciniuose sakiniuose jie nekonkretizuojami, tik pasakoma, kad šalyje kyla sujudimas, šaukiama ị kovą, kalbama apie artẻjančius didelius ịvykius, kurių atgarsiai pasiekia ir Lietuvą (žr. 1-3 sakinius).

(1) Visuomeninis sujudimas auga Rusijoje visoje liaudyje, visose jos klasèse rš (ž. sujudimas) ${ }^{19}$.

(2) Jaunosios Rusijos kovos šaukimas prasiskverbia net ị aklinai uždarytas kareivines rš (ž. kareivinès).

(3) Obelių apylinkes, kaip ir visa Lietuva, pasieke didžiujjų Rusijos j̣vykių aidas ř̌ (ž. aidas).

Vienas iš svarbesnių aptariamojo laikotarpio įvykių Rusijos istorijoje $\mathrm{XX}$ a. pradžioje kilusi revoliucija. Pastebima, kad šalyje vyko dvi viena po kitos revoliucijos (žr. 4 sakinị).

(4) Dviejų Rusijos revoliuciju patyrimo išnagrinẹjimas rš (ž. išnagrinèjimas).

Iliustraciniuose sakiniuose, kuriuose kalbama apie artėjančią revoliuciją, šalis metaforiškai lyginama su nëščia moterimi (žr. 5 sakinį), svarstoma, kas pirmieji pradèjo revoliuciją (žr. 6 sakinị), konkrečiai ịvardijama data, kada ji prasidejjo (žr. 7 sakinị).

(5) Rusija buvo néščia revoliucija daugiau nei bet kuri kita šalis rš (ž. nèščias).

(6) Rusijoje revoliucija, girdi, pradëję jūrininkai, tai ir Vokietijoje jūreivija, nusižiūrëjusi, èmusi riaušes kelti I. Simon (ž. jūreivija).

(7) 1905 metu sausio 9 dienq darbininkų kraujuje gimé pirmoji Rusijos revoliucija (sov.) rš (ž. kraujas).

19 Pavyzdžiai cituojami iš elektroninės LKŽe versijos (žr. www.lkz.lt). Santrumpų sąrašas pateikiamas straipsnio gale. Skliaustuose nurodomas žodis, iš kurio leksikografinio straipsnio imtas pavyzdys. 
Kalbama apie revoliucijos formas (žr. 8 sakinị), svarstoma, kokios buvo revoliucijos pasekmès Rusijai ir pan. (žr. 9 sakini).

(8) Kovos formos Rusijos revoliucijoje pasižymi milžinišku ịvairumu, palyginti su buržuazinemis Europos revoliucijomis rš (ž. įvairumas).

(9) Didžiosios Spalio socialistinès revoliucijos rezultatas buvo Rusijos iškritimas iš pasaulinès kapitalizmo sistemos (sov.) rš (ž. iškritimas).

Sovietiniais metais užrašytose iliustracijose pašiepiami ponai (žr. 10 sakinị), iškeliama partijos svarba (žr. 11 sakinị).

(10) Ponékams, pabègusiems nuo Rusijos revoliucijos kiauromis kelnemis, terūpi savo gerove (sov.) rš (ž. ponèkas).

(11) Mūsų partijos suvažiavimas buvo vienintelis tokios rūšies, neregètas reiškinys visoje Rusijos revoliucinio judëjimo istorijoje (sov.) rš (ž. reiškinys).

\subsection{Ekonomika, ūkis}

Apie Rusijos ekonomiką, ūkį LKŽe rasta visai mažai sakinių. Iš jų galima ši tą sužinoti apie Rusijoje buvusius mokesčius (žr. 12 sakinị), mažųuu ūkių gyvavimą (žr. 13 sakini).

(12) Jau ir dabar Rusijos arbatos uždas yra pats didžiausias pasaulyje rš (ž. uždas).

(13) Pačioje Rusijoje yra jau toki mažieji ūkiai, kurie už vištas ir kiaušinius tūkstančius rubliu išverčia Pt (ž. išversti).

Sovietiniais metais iš raštų išrašytuose sakiniuose kalbama apie šalyje nuolat didejjantị fabrikų skaičiu (žr. 14 sakinį), stambiosios pramonės plètimąsi ir pan. (žr. 15 sakinį).

(14) Fabriku skaičius Rusijoje didëja ir gana sparčiai didëja rš (̌̌. gana).

(15) Plieno išlydymas 1940 metais TSRS rytiniuose rajonuose 1,4 karto viršijo visos Rusijos 1913 metu plieno išlydyma rš (ž. išlydymas).

Fiksuota ir gana tuščių, lozungus primenančių pompastiškų sakinių (žr. 16 sakinį).

(16) Ekonomine Rusijos istorija tuo būdu jau ịrodè tai, kq rytoj ịrodys politine Rusijos istorija rš (ž. įrodyti).

Tokios iliustracijos apie augančią pramonę, gamybą, bandymą kažką įrodyti politikoje, siekimą išlaikyti statusą ir prestižą tarptautineje politikoje tik paliudija šiandienos istorikų ir politikų keliamą mintį, kad Rusija ir jos lyderiai šimtmečiais siekè ir tebesiekia „didžiosios valstybės statuso“ (Janeliūnas, Kojala 2016: 13). Šiandienos kontekste matyti, „kad „imperine““ retorika skamba visuose Rusijos politinio diskurso segmentuose“ (Malinova 2015: 273), o visa tai ataidi dar iš sovietinès imperijos laikų, kurie gana ryškiai atsispindi ir akademinio žodyno iliustraciniuose sakiniuose. 
Kiek kitaip Rusijos vaizdas atrodo šnektų atstovams. Lietuvai atgavus nepriklausomybę jau nebijoma pasakyti savo nuomonès apie skurdų žmonių gyvenimą Rusijoje (žr. 17-19 sakinius).

(17) O Rusijoj visi laukai tušti, ažužèlę, žmonès kaip vilkai vaikšto $\mathrm{Ob}$ (ž. vilkas).

(18) Visa Rusija išsivogta: vienas nuo kito vagia Jrb (ž. išvogti).

(19) Visq Rusija apëjau, tei[p], kai jie gyvena, niekur pasauly nèsu matęs Jrb (ž. visas).

\subsection{Ryšys su Lietuva}

LKŽe fiksuota nemažai sakinių, kuriuose kalbama apie Rusijos ir Lietuvos santykius. Abiejų šalių gyventojai nuolat migravo iš vienos šalies kitą. Iš šnektose užrašytų sakinių aiškejja, kad lietuviai dažniausiai į Rusiją bėgo ar pakliūdavo dèl karų (žr. 20 sakini), suiručiu (žr. 21 sakinị) ir pan.

(20) Jis per karą, sako, net Rusijon atsikliuvo Lš (ž. atkliūti).

(21) Kai pervertimai buvo, anas Rosijon išbègo Ob (̌̌. vertimas).

Kiti vykdavo į Rusiją dirbti ar gydytis (žr. 22-23 sakinius).

(22) Rusijo[je] b[uv]au pasitraukęs j Kazanę, dirbau Kazané[je] Žd (ž. patraukti).

(23) Jaunas talentuotas rašytojas humoristas Juozas Gurauskis, pačiame žaliume džiovos pakirstas, kankinasi kaži kokioje Rusijos sanatorijoje $\mathrm{Pt}$ (ž. žaliumas).

Lietuviams teko atlikti karinę tarnybą Rusijos armijoje (žr. 24 sakinį). Sovietmečiu užrašytame sakinyje su pasidžiavimu pabrèžiama, kad ị sovietinę armiją patekdavo geriausi Lietuvos jaunuoliai (žr. 25 sakini).

(24) Pradëjęs savo žygị Rusijos gilumoje, lietuviškas Tarybinès Armijos junginys nuëjo garbingų kovų ir pergalių keliq ligi Baltijos jūros pakrantès (sov.) sp (ž. junginys).

(25) Ji (Lietuva) atidavé savo jaunimo žiedą Rusijos armijai P. Klim (ž. žiedas).

Šnektose užrašytas ne vienas paliudijimas, kad žmonès ị Rusiją buvo išvežami per prievartą: minimi XIX a. pabaigos - XX a. pradžios trėmimai (žr. 26 sakinị), atkūrus Lietuvai nepriklausomybę ir išsivadavus iš aktyvios ir akylos sovietinès cenzūros žodyno tekste imami minèti ir masiniai gyventoju trèmimai 1940-1953 m. (žr. 27-28 sakinius).

(26) Per pirmajị kara buvau ị Rusija pavilkta - tris metus ir šešis mènesius Vlkš (ž. pavilkti).

(27) Septynių metų buvau vaikas, ka išvaré mumis ị Rusijq̨ Škn (ž. išvaryti).

(28) Vyrų daug išveže į Rusija, kame padoresnis ūkininkas, visus išvežè K1 (ž. vežti). 
Kai kuriuose iš šnektų ir raštų užrašytuose sakiniuose konkrečiai neįvardijama, kokiu metu ir dèl kokių priežasčių lietuviai pasitraukdavo ị Rusiją (žr. 29-31 sakinius).

(29) Ir anudu ketino jau traukties j Rusiją Krt (ž. traukti).

(30) Sūnus išbuvo aštuonis metus Rusijo[je] išvažiavęs Žlb (̌̌. išvažiuoti).

(31) Lietuvoje nieko neradęs, iškeliauja Rusijon ir ten amžinai nusèda rš (ž. nusèsti).

Vyko ir atgalinis judejjimas. Iš Rusijos ir į Lietuvą atvykdavo nemažai rusų, tikėdamiesi čia geresnio, kiek laisvesnio gyvenimo. Užsimenama, kad Lietuva rusus traukè kaip Amerika, čia jie gaudavo darbo (žr. 32-33 sakinius).

(32) Virto iš tos Rusijos čia an galvos, kaip ị Amerikq End (̌̌. virsti).

(33) Tai būdavo miško darbinykai vis suvažiavę iš kur, atvažiavę ar iš Rusijos, ar iš kur $\mathrm{Sb}$ (ž. suvažiuoti).

Iš iliustracijų matyti, kad ị Lietuvą iš Rusijos atvykdavo ištisos bendruomenès. Pavyzdžiui, sentikiai čia atsikèlè dèl persekiojimo Rusijoje (žr. 34 sakinį).

(34) XVII a. Lietuvoje atsirado dar vienos krikščionybès šakos išpažineju - sentikių. Jie atsikèle iš Rusijos, nes ten tuo laiku buvo smarkiai persekiojami MLTEIII60 (ž. sentikis).

Rusai ị Lietuvą vyko ne tik savo noru, bet buvo ir prievarta atvežami (žr. 35-36 sakinius).

(35) Any (rusai) privežta iš Rasiejaus Nmč (ž. privežti).

(36) Ventos tilta pri Mažeikių kad dirbo, buvo maskoliai iš Maskolijos atvežti su mediniais ratais Šts (ž. maskolis).

Vyko ne tik žmonių migracija. Iš Lietuvos ị Rusiją buvo gabenamos ìvairios prekès (žr. 37 sakini).

(37) Upeivos gabeno prekes $j$ Rusija Kin (ž. upeiva).

Iš Rusijos ị Lietuvą atkeliavo ne tik žmonès, bet ir ligos:

(38) Cholera buvo iš Rusijos (tada ji ten plètessi) užvežta Pt (ž. užvežti).

Ne vienoje iliustracijoje randame paliudijimą, kad Rytų ir Vakarų kryžkelejje esančią Lietuvą vis paliesdavo didžiosiose šalyse vykstantys ịvykiai. Pavyzdžiui, iš Vokietijos ị Rusiją nutiesti geležinkeliai ir keliai èjo per Kauną (žr. 39 sakinị); sudarius Rusijai ir Vokietijai taiką, ị Lietuvą galèjo grịžti karo pabègèliai (žr. 40 sakinị) ir pan.

(39) Kaunas vaidino labai svarbu strategini vaidmeni, nes pro ji èjo pagrindiniai geležinkeliai ir plentai iš Vokietijos $j$ Rusija MLTEII98 (ž. strateginis).

(40) 1918 metų kovo menesị sudarius taika tarp Tarybų Rusijos ir Vokietijos, i Lietuvą èmé grįžti karo pabègèliai rš (ž. tarp). 
Lozungus primenančiuose sakiniuose kalbama, kokią ittaką Rusijoje vykstantys ịvykiai darè Lietuvai (žr. 41 sakinị).

(41) Visoje Rusijoje sparčiai plètojantis kapitalizmui, Lietuvoje augo ir konsolidavosi darbininkų klasè (sov.) rš (ž. konsoliduoti).

\subsection{Idejos, partijos, valdininkai}

Sovietiniu laikotarpiu užrašytuose sakiniuose kalbama apie marksizmo, leninizmo idejas (žr. 42 sakinị); minimos publicistų, filosofų ir kt. visuomenės veikèjų (Visariono Belinskio, Aleksandro Gerceno, Nikolajaus Černyševskio ir kt.) pavardès (žr. 42-43 sakinius).

(42) Bielinskis, Gercenas savo mokslo, publicistikos ir meno veikalais paruoše dirva marksizmo-leninizmo idejoms Rusijoj prisiimti rš (̌̌. priimti).

(43) Černyševskis nesugebëjo, teisingiau, negalëjo dèl Rusijos gyvenimo atsilikimo pakilti iki Markso ir Engelso dialektinio materializmo (sov.) rš (ž. pakilti).

Keliuose sakiniuose kalbama apie kapitalizmą Rusijoje. Apie ji rašomos knygos (žr. 44 sakinị), ši socialinè ekonominè sistema Rusijoje ir augo, ir buvo griaunama (žr. 45-46 sakinius).

(44) Rašè knyga „Kapitalizmo išrutula Rusijoje“ rš (ž. išrutula).

(45) Rusijoje buvo likviduota senoji, kapitalistine bazè rš (ž. kapitalistinis).

(46) Panaikinus baudžiava, Rusijoje pradëjo sparčiai augti kapitalizmas rš (ž. kapitalizmas).

Sovietinio laikotarpio iliustracijose minimas komunizmas, pabrèžiama Rusijoje vykusios Spalio revoliucijos, pakeitusios geopolitinę situaciją Rytų ir Vidurio Europoje, svarba (žr. 47 sakinị).

(47) Spalio socialistine revoliucija Rusijoje nurodo visų šaliu proletarams keliq, kuriuo jie turi eiti i šviesu tiksla - komunizma (sov.) sp (ž. proletaras).

Apie Rusijoje veikiančias partijas kalbama iš raštu išrašytuose sakiniuose: minimi liberalai, socialdemokratai ir kt. (žr. 48-49 sakinius).

(48) Rusijos liberalai niekuomet nebuvo suorganizavę revoliucinés partijos kovai dèl patvaldystès nuvertimo rš (ž. liberalas).

(49) Rusijos socialdemokratai užsibrěže sau artimiausia politinị uždavini nuversti monarchija (sov.) rš (ž. monarchija).

Iš iliustracijų matyti, kad Rusijoje buvo daug visokiausių valdininkų, jie buvo siunčiami ị Lietuvą vykdyti ūkio ir kultūros sovietinimo (žr. 50 sakinị).

(50) Toji valdininkija buvo kaip tyčiomis suverbuota iš visos Rusijos rš (ž. suverbuoti). 


\subsection{Socialinès grupès}

LKŽe iliustraciniuose sakiniuose daugiausia dèmesio tenka valstiečiams. Pastebima, kad net panaikinus baudžiavą ju gyvenimas nebuvo lengvas (žr. 51-52 sakinius).

(51) Valstiečiu žemèvalda Rusijoje ..., tiek ir privatine (nuomotine ir pirktine žemè) ... apraizgyta senais, pusiau baudžiaviniais ryšiais ir santykiais (sov.) rš (ž. nuomotinis).

(52) $O$ iš ko susideda visa poreformine Rusijos istorija, jeigu ne iš masinio, niekur nematy to tokio intensyvaus valstiečì eksproprijavimo? rš (ž. masinis).

Sovietmečio iliustracijose akcentuojama, kad valstiečiai buvo labai stipri socialinė klasė, o kartu su darbininkais Rusijoje jie tapo revoliucijos varomąja jèga (žr. 53-54 sakinius).

(53) Lietuvos, kaip ir antrinès Rusijos imperijos dalies, narodnikai pagrindine revoliucijos jega laike valstiečius rš (ž. valstiečiai).

(54) Valstiečiai, gausingiausia priešrevoliucinès Rusijos klasè, iro, skilo $\dot{i}$ sluoksnius sp (ž. irti).

Rašant bei redaguojant žodyną sovietų laikais, nemažas dėmesys buvo skiriamas ir darbininkams, stengtasi pabrěžti, kad Rusijos istorijoje darbininkų klasè ne mažiau svarbi nei valstiečiai: Pirmajam pasauliniam karui einant ị pabaigą, ,darbininkai, paėmę valdžią kartu su vargingaisiais valstiečiais, turèjo stiprinti Tarybų Rusiją“ (Laurinavičius 1997: 53). LKŽe iliustracijos liudija, kaip panaikinus baudžiavą stiprèjo darbininkų savimonė (žr. 55 sakinị), jie aktyviai dalyvavo proletarinejje kovoje (žr. 56 sakini).

(55) Panaikinus baudžiava, Rusijoje sparčiais tempais augo kapitalizmas, formavosi ir telkèsi darbininkų klasé, stiprëjo jos klasinè savimonè sp (ž. savimonè).

(56) Proletariné kova apimdavo naujus darbininku sluoksnius ir plito visoje Rusijoje (sov.) rš (ž. proletarinis).

Apie kilmingųjų luomus LKŽe iliustracijoje beveik nekalbama. Fiksuotas tik vienas sakinys apie Rusijos imperijoje buvusią pareigybę - bajorų vadovą (žr. 57 sakinị).

(57) Bajory vadovas - Rusijos imperijos bajoru luomines organizacijos pareigūnas LTEI166 (ž. vadovas).

\section{6. Žmonių ir tautų padètis Rusijoje}

LKŽe randame šiek tiek informacijos apie ịvairių tautų gyvenimą Rusijoje. Pirmiausia konstatuojama, kad šalyje gyveno visokių tautų žmonių (žr. 58 sakini):

(58) Nacionaliniu atžvilgiu Rusija yra marga šalis rš (ž. šalis). 
Pripažistama, kad kitų šalyje gyvenančių tautų palaikymas buvo labai svarbus Rusijos pažangai (žr. 59 sakinị).

(59) Leninas nepaliaujamai kartodavo, kad be sqjungos su šiomis kitatautèmis masèmis Rusijos proletariatas negalès nugalèti (sov.) rš (̌̌. kitatautis).

Žodyno iliustracijose net neužsimenama apie ano meto Rusijos žmonių, tautų laisvę ar klestėimą. Šis faktas tik patvirtina Alexanderio Etkindo mintį, kad imperinè valstybė savo kontinentinejje teritorijoje vykdo „vidinę kolonizaciją“ ir mažiau išvystytoms teritorijoms nustato aiškų hierarchini santykị (Etkind 2011: 2).

Tačiau galima rasti užuominų apie Rusijoje stipriai veikusią cenzūrą (žr. 60 sakini):

(60) Tiktai pagalvokite, kaip reikia sužaloti šiq revoliucinę doktrina, kad ja būtu galima ịtalpinti ị Rusijos cenzūros Prokrusto lovą! rš (ž. įtalpinti).

Apie sovietiniais metais vykdytas represijas, masinius trèmimus, apskritai apie totalitarinę sovietų santvarką, tuo metu vyravusią baimę, prievartą sakiniuose su Rusija išvis nekalbama. Šis faktas dar syki parodo, kaip stipriai tuo metu žodyno rašytojus ir redaktorius veikė cenzūra. Akivaizdu, kaip tuo metu buvo svarbu iš informacinio lauko pašalinti nepageidaujamą informaciją, o atsiradusią tuščią erdvę užpildyti propagandiniu turiniu (plg. Sẻdaitytė 2017: 85). Iliustracijos apie realų, nepagražintą lietuvių gyvenimą sovietinès okupacijos sąlygomis, apie okupacinès valdžios ịtaką mūsų valstybès ir kiekvieno lietuvio gyvenimui pateko tik į žodyno Papildymų (LKŽP) ir Tarmių (LKŽT) kartotekas ${ }^{20}$.

\subsection{Gamta, mokslas, menas}

Rusijos didumas pabrèžiamas būdvardžiais gilus, didis, tolimas ir pan. (žr. 61 sakinị).

(61) Kai jis mirè, aš jau gyvenau tolimoj Rusijoj ir savarankiškai verčiaus farmacijos praktika A. Vien. (ž. praktika).

${ }^{20}$ Pastebėta, kad LKŽP fiksuota daug daugiau iliustracijų ne su vietovardžiu Rusija, o su etnonimu rusas. Tiriant tokių sakinių semantiką ryškèja ne tik lietuvių santykiai su konkrečios tautybès asmenimis, bet ir požiūris ị pačią Rusiją. Plg. LKŽe pateikiamą vieną iš ruso homonimų - 'Rusijos valdžia; Rusijos kariuomenë. LKŽP ir LKŽT iliustracijose, užrašytose Lietuvai atgavus nepriklausomybę, rusai ir jų įvesta santvarka, valdžia vertinami nepagražintai: Kur jau rusas užějo, jau ir užëjo (pasiliko ilgam) Antãlieptė (LKŽP 1998). Baisūs buvo laikai [pokaryje], užèjo rusas ir padarè [savo tvarka] Nemunẽlio Radviliškis (LKŽT 2009). Ar galëjo Lietuvèle atsilaikyti prieš rusą, prieš tokiq tautq̨? Nemunẽlio Radviliškis (LKŽT 2009). 
Tik 4 LKŽe iliustracijose kalbama apie Rusijos gamtą: minima Rytu Europos lyguma ir Rusijos skydas, pabrėžiama, kad Rusijoje yra derlingu dirvožemių (žr. 62-63 sakinius).

(62) Rusijos stepiu ir miškastepiu rajonai turi derlingiausia juodžemio dirvožemị rš (ž. miškastepè).

(63) Estijos žemès paviršius yra dalis didžiosios Rytų Europos lygumos Rusijos skydo EncVII1092 (ž. skydas).

Užsimenama, kad tai vejjuotas kraštas su labai šaltomis žiemomis (žr. 64-65 sakinius).

(64) Rusijo[je] tas i didliai vëjuotas kraštas Ms (ž. vejuotas).

(65) Ta žiema i Rusiją dideli šalčiai buvo, vokytis ir pašalo Sg (ž. vokytis).

LKŽe iliustracijose tik keliais žodžiais užsimenama apie Rusijos mokslą ir meną. Dviejuose sakiniuose minimi šios šalies klinikose dirbantys gydytojai ir bežiedžius augalus tyrinèjantys mokslininkai (žr. 66-67 sakinius).

(66) Geriausi Rusijos klinicistai visuomet kreipé demesị i skirtinga ivvairiu žmonių ligos eiga ir todèl moke ,gydyti ligonį, bet ne liga“ "rš (ž. klinicistas).

(67) Jis yra pirmasis Rusijoj kriptogamininkas, panaudojęs citologinį metoda grybams tirti J. Dag. (ž. kriptogramininkas).

Viename sakinyje kalbama apie archeologų tiriamą dantytosios keramikos kultūrą (žr. 68 sakinị).

(68) Ypač gražiai duobetosios-dantytosios keramikos kultūra yra pasireiškusi vidurio Rusijoje ir šiu dienu Suomijoje rš (ž. kultūra).

\section{Rusija reikšmių apibrèžtyse}

Rusija minima ne tik LKŽe iliustracijose, bet ir reikšmių apibrèžtyse, kurių turinys taip pat ne mažiau svarbus formuluojant bendrą RUSIJOS konceptą. Kalbininkai ne sykị yra pabrèžę, kad žodynuose pateiktos reikšmių apibrèžtys yra svarbus istorinės ir kultūrinès informacijos šaltinis (Skybina, Bytko 2015: 28tt), bemaž kiekviename žodyne ne tik iliustracijose, bet ir reikšmių apibrěžtyse galima rasti nemažai enciklopedinès informacijos (Kiefer 1988: 8; Wnęk, Bendoraitytė-Vnęk 2012: 82tt; Valančiauskienė 2019), nes „žodžiai ir pasaulis yra neatsiejami“ (Kirkness 2004: 60). Iš viso LKŽe rasta 71 reikšmès apibrèžtis, kurioje minima Rusija. Ši leksema pasitelkiama apibèžti 69 daiktavardžiams ir 2 būdvardžiams (baltas, rusinis). Pabrèžtina, kad net 33 reikšmių apibrèžtys susijusios su carine Rusija. Jos iš bendros imties elimintuotos ir šiame straipsnyje analizuojamos likusios 38 apibrèžtys, kurių turinys labiau sietinas su sovietiniu laikotarpiu.

Iš tiriamųju reikšmiu apibrèžčių išryškejja dar keli svarbūs RUSIJOS koncepto bruožai. 


\subsection{Svarbios Rusijos datos}

Keliose reikšmių apibrèžtyse minimos konkrečios datos. Iš reikšmių apibrěžčiu galima sužinoti, kad Rusijoje 1917 m. laikinosios vyriausybės galva tapo Kerenskis (̌̌. kerenka), 1917-1918 m. šalyje vyko ginkluotų darbininkų kova (̌̌. gvardija), o 1918-1920 m. vyko Rusijos pilietinis karas (ž. gvardija).

\subsection{Tautos, klasès, luomai}

Reikšmių apibrèžtyse minima keletas Rusijoje gyvenančių tautų: rùsai 'tauta, kalbanti viena rytų slavų kalbų, gyvenanti daugiausia Rusijoje', koriãkai 'tauta, gyvenanti Rusijoje (Kamčiatkoje ir Magadano srityje)' ir kt.

Be tautų, reikšmių apibrèžtyse minimos ir Rusijoje buvusios socialinès grupès: dvarininkai, valstiečiai (ž. atraižai), laisvieji žmonès, baudžiauninkai, tarnai, miesto varguomenè (̌̌. 2 kazokas).

\subsection{Kariuomenè, policija}

Žodyne Rusija minima apibrèžiant keletą su kariuomene ir policija susijusių terminų: milicija 'buvusioje TSRS ir dabar Rusijoje administracinè isstaiga visuomeniniam saugumui ir tvarkai palaikyti', rùsas 'Rusijos valdžia; Rusijos kariuomenë', ruskíejai 'Rusijos valdžia; Rusijos kariuomenè' ir kt.

\subsection{Srovès, judèjimai, partijos}

Didelèje šalyje formavosi ir veikẻ ịvairūs visuomeniniai, politiniai judejjimai ir srovès. LKŽe reikšmių apibrèžtyse minimas ekonomìzmas 'oportunistinè Rusijos socialdemokratų srovè, skelbusi, kad darbininkai turi kovoti tik dèl savo ekonominio būvio pagerinimo', nihilizmas 'nuo 1860 metų Rusijoje - rusų visuomeninès minties srovè, nukreipta prieš reakcinès bajorijos tradicijas, prieš bajorinès kultūros principus', narodnikỹste ‘Rusijos XIX amžiaus antrosios pusės smulkiosios buržuazijos visuomeninis-politinis judejjimas, idealizavęs valstiečių bendruomenę, neigęs vadovaujantį darbininkų klasès vaidmeni revoliucijoje’.

Apibrěžiami kai kurių organizacijų, partijų narių pavadinimai: bolševìkas 'Rusijos socialdemokratų darbininkų partijos revoliucinės daugumos narys', nihilistas 'nuo 1860 metų Rusijoje - nebajorų inteligentijos ${ }^{21}$ atstovas, neigiantis reakcinès bajorijos tradicijas, baudžiavinès ideologijos papročius' ir kt.

${ }^{21}$ İdomu tai, kad nei LKŽe iliustracijose, nei reikšmių apibrèžtyse su leksma Rusija daugiau nẻ karto nepaminèta inteligentija, o būtent inteligentijos sluoksnio atsiradimas yra „viena svabiausių prielaidų susiformuoti moderniai tautai“ (Aleksandravičius, Kulakauskas 1996: 224). 


\subsection{Piniginiai vienetai}

Kelios apibrèžtys skirtos sovietinėje Rusijoje cirkuliavusiems piniginiams vienetams pavadinti: kèrenka 'popierinis 20 ir 40 rublių vertès pinigas, išleistas Rusijoje 1917 m., kai laikinosios vyriausybės galva buvo Kerenskis', rùblis 'TSR Sąungos (ir ikirevoliucinès Rusijos) pagrindinis piniginis vienetas, lygus šimtui kapeikų; tos vertès piniginis ženklas' ir kt.

\section{Apibendrinimas ir išvados}

Ištyrus 118 LKŽe iliustracinių sakinių ir 38 reikšmių apibrèžtis, kuriose paminèta leksema Rusija, matyti, kad žodyne ryškiausiai atsispindi sovietmečio kolektyvinẻ lietuvių atmintis. Ji kuria tikrais įvykiais grịstą praeities aprašymą, kurị ne vieną dešimtmeti pasakojo daugybė žmonių (tarmių informantai ir rašytinių šaltinių autoriai), tačiau tas pasakojimas buvo labai stipriai paveiktas to meto viešojo sektoriaus sovietinès cenzūros ir žodyno informantų, autorių bei redaktorių vidinės savicenzūros. Kadangi šis žodynas nepildomas šiuolaikinių diskursų pavyzdžiais, šiame straipsnyje išanalizuoti duomenys leidžia nustatyti nuo Spalio revoliucijos iki XXI a. kalbos vartotojų sąmonejje verbalizuotą RUSIJOS konceptą.

Žodyno iliustracijose atsiskleidžia keli svarbūs RUSIJOS koncepto požymiai. Tai didelè šalis su šaltomis žiemomis, turinti lygumų, derlingų dirvožemių. Vienas iš svarbiausių to meto politinių įvykių - $1917 \mathrm{~m}$. vykusi spalio revoliucija, kuri pakeite geopolitinę situaciją Rytų ir Vidurio Europoje.

Didelèje daugiatauteje šalyje jos gyventojai ir ịvairios tautos nuolat migravo. Iš šnektose užrašytų sakinių aiškejja, kad dažniausiai ị šią šalį lietuviai bėgo dẻl karų, dalis lietuvių vyko ị šią šalį dirbti, gydytis, atlikti karinės tarnybos. Šnektose užrašyta liudijimų, kad žmonès į Rusiją buvo išvežami per prievartą. Minimi ankstesni (XIX a. pabaigos - XX a. pradžios) ir po Antrojo pasaulinio karo vykę masiniai gyventojų trèmimai. Iliustracijose kalbama ir apie atgalinị judejiimą. Iš Rusijos ir ị Lietuvą atvykdavo nemažai rusų: pavieniai rusai Lietuvoje gaudavo darbo, taip pat į Lietuvą iš Rusijos atvykdavo ir ištisos bendruomenès. Vyko ne tik žmonių migracija. Iš Lietuvos ir kitų šalių į Rusiją buvo vežamos įvairios prekès, o iš Rusijos atkeliaudavo ne tik žmonès, bet ir ligos.

Sovietinio laikotarpio iliustracijose ypač daug kalbama apie marksizmo, leninizmo, kapitalizmo, komunizmo ir kt. idejas, minimos to meto publicistų, filosofų ir kt. visuomenès veikèjų pavardès (Visariono Belinskio, Aleksandro Gerceno, Nikolajaus Černyševskio ir kt.), politinès partijos ir socialinès grupès. To meto iliustracijose pašiepiami ponai, iškeliama komunistų partijos 
svarba, kalbama apie Rusijoje nuolat didejjantị fabrikų skaičių, stambiosios pramonès plètimąsi ir pan. Dalis tokių sakinių skamba pompastiškai, primena lozungus. Rastos tik kelios iliustracijos apie Rusijos meną, mokslą. Taip pat sovietmečiu užrašytose iliustracijose net neužsimenama apie ano meto Rusijos žmonių ar tautų laisvę, klestėjimą, išvis nekalbama apie vykdytas represijas, masinius trèmimus, apskritai apie totalitarinę sovietų santvarką, tuo metu vyravusią baimę. Šie faktai aiškiai parodo, kaip stipriai tuo metu žodyno rašytojus ir redaktorius veikẻ sovietinè cenzūra ir kaip plačiai buvo vykdoma ideologinè kontrolè. Iliustracijos apie realų, nepagražintą lietuvių gyvenimą sovietinès okupacijos sąlygomis, apie okupacinės valdžios įtaką lietuvių gyvenimui pateko tik ị žodyno Papildymų bei Tarmių kartotekas.

Reikšmių apibrèžčių turinys taip pat ne mažiau svarbus formuluojant bendrą RUSIJOS konceptą. Iš tiriamųjų reikšmių apibrèžčių susidèlioja panašus RUSIJOS konceptas kaip ir iliustraciniuose sakiniuose, tik pastebėta, kad reikšmių apibrèžtyse daugiau konkretumo: čia nurodomos tikslios istorinès datos, minima daugiau Rusijoje gyvenančių tautų, socialinių grupių, luomų, srovių, judejjimų, partijų. Rusija minima apibrěžiant su kariuomene ir policija susijusius terminus bei piniginių vienetų pavadinimus.

Pastebėta, kad reikšmių apibrèžtyse pateikiami konkretūs, tikslūs su tiriamuoju objektu susiję faktai, o iliustracijose, be istorinio naratyvo, galima įžvelgti daugiau subjektyvumo, netgi emocingumo, kuris dažniausiai pasireiškia pirmuoju asmeniu užrašytuose sakiniuose.

\section{Straipsnyje vartotos Lietuvių kalbos žodyno vietovių ir rašytinių šaltinių santrumpos}

J. Dag - Jonas Dagys (1906-1993), jo raštai (botanika).

Enc - Lietuviškoji enciklopedija. I-IX tm. Kaunas 1933-1940. (Jei žodis enciklopedijoje ne antraštinis, skaitmenys rodo tomus ir skiltis.)

End - Endriejãvas, Klaipedos r.

Jrb - Jùrbarkas.

Kin - Kintaí, Šilutès r.

$\mathrm{K} 1$ - Kuliai, Plungès r.

P. Klim - Petras Klimas (1891-1969), jo raštai ir vadovèliai.

Kzt - Kazitiškis, Ignalinos r.

Lš - Liškiavà, Varènos $r$.

LTE - Lietuviškoji tarybinè enciklopedija, 1-12, Papildymai, Vilnius 1976-1985.

(Skaitmenys rodo tomus ir puslapius.)

MLTE - Mažoji lietuviškoji tarybinè enciklopedija, I-III tm. Lietuvos TSR Mokslu akademija. Vilnius 1966-1971. (Skaitmenys rodo tomus ir puslapius.)

Ms - Mósèdis, Skuodo r.

Nmč - Nemenčinè, Vilniaus r. 
$\mathrm{Ob}$ - Obẽliai, Rokiškio r.

Pt - Gabrielè Petkevičaitė-Bitè (1961-1943), jos raštai.

rš - raštų žodis ar sakinys.

$\mathrm{Sb}$ - Subãčius, Kupiškio $\mathrm{r}$.

$\mathrm{Sg}$ - Saũgos, Šilutès r.

I. Simon - Ieva Simonaityte (1897-1978), jos raštai.

sp - spaudos žodis ar sakinys.

Škn - Šakýna, Šiaulių r.

Šts - Šãtės, Skuodo r.

A. Vien - Antanas Vienuolis-Žukauskas (1882-1957), jo raštai.

Vlkš - Vilkỹškiai, Šilutès r.

Žd - Židìkai, Mažeikių r.

Žlb - Žlibinaĩ, Plungès r.

\section{Literatūra}

Aleksandravičius, Egidijus, Caru valdžioje. XIX a. Lietuva. Vilnius: Baltos lankos.

Kulakauskas, Antanas. 1996.

Bartmiński, Jerzy. 2007. Językowe podstawy obrazu świata. Lublin: Wydawnictwo UMCS.

Burinskaite, Kristina. 2005. Lietuvos ir Rusijos santykiai XV-XX a. Vilnius: Alma littera.

Etkind, Alexander. 2011. Etkind, Alexander. 2011. Internal Colonization: Russia's Imperial Expierience. Cambridge: Polity.

Gritenene, Aurelija. 2020. Koncept carskoj Rossii v «Slovare litovskogo jazyka». Aktual ni problemy sučasnoji osvity ta nauky $v$ konteksti jevrointehracijnoho postupu. Luc'k: Veža-Druk, 273-283.

Gritėnienè, Aurelija. 2016. Šrermukšnio vaizdinys „Lietuvių kalbos žodyne“. Tautosakos darbai 52, 85-104.

Gritėnienè, Aurelija. 2017. Žodyno vaizdinys Lietuvių kalbos žodyne. Bendrine kalba 90, 1-19. Prieiga internete: http://www.bendrinekalba.lt/?90.

Gudavičius, Aloyzas. 2009. Etnolingvistika: Tauta kalboje. Šiauliai: Šiaulių universiteto leidykla.

Gudavičius, Aloyzas. 2011. Reikšmè - sąvoka - konceptas ir prasmè. Res humanitariae 10, 108-119. Prieiga internete: http://etalpykla.lituanistikadb. lt/fedora/objects/LT-LDB-0001:J.04 2011 1367184173024/ datastreams/DS.002.0.01.ARTIC/content.

Janeliūnas, Tomas, Kojala, Struktūriniai veiksniai ir Rusijos užsienio politika: tapatybès Linas. 2016. naratyvų simuliacija V. Putino režime. Vilius Ivanauskas, Tomas Janeliūnas, Gražvydas Jasutis, Laurynas Jonavičius, Laurynas Kasčiūnas, Vytautas Keršanskas, Linas Kojala. Rusijos raidos scenarijai: implikacijos Lietuvos ir regiono saugumui. Vilnius: Rytų Europos studijų centras, 13-54.

Kiefer, Ferenc. 1988. Linguistic, Conceptual and Encyclopedic Knowledge: Some Implications for Lexicography. Prieiga internete: https://www. euralex.org/elx_proceedings/Euralex1988/005_Ferenc_Kiefer_ Linguistic, Conceptual and Encyclopedic Knowledge - Some Implications for Lexicography.pdf 
Kirkness, Alan. 2004.

Kruopas, Jonas. 1948.

LKŽe =

LKŽ instrukcija. 1980.

Malinova, Olga. 2015.

Naktiniené, Gertrūda. 2012.

Nepokupnas, Anatolijus. 2002.

Nowak, Andrzej. 2015.

Papaurèlytė-Klovienè, Silvija. 2007.

Rutkovska, Kristina,

Smetona, Marius,

Smetoniené, Irena. 2017.

Sèdaitytè, Edita. 2017.

Skybina, Valentyna, Bytko, Nataliya. 2015.

Smetonienè, Irena. 2019.

Subačius, Paulius. 1999.

Šimènaite, Zita. 2010.

Tamulionienè, Aurelija. 2003.
Lexicography. The Handbook of Applied Linguistics. Ed. Alan Davies and Catherine Elder. Blackwell Publishing Ltd., 54-82. Lietuvių kalbos žodynas. Tarybine mokykla 12, 45-46.

Lietuviu kalbos žodynas (t. I-XX, 1941-2002): elektroninis variantas. Redaktorių kolegija: Gertrūda Naktinienè (vyr. redaktorè), Jonas Paulauskas, Ritutè Petrokienè, Vytautas Vitkauskas, Jolanta Zabarskaitè. - Vilnius: Lietuvių kalbos institutas, 2005 (atnaujinta versija, 2008 ir 2018). Prieiga internete: www.lkz.lt.

„Lietuvių kalbos žodyno“ instrukcija. Vilnius: Lietuvių kalbos ir literatūros institutas.

Kolektyvinès praeities ideja posovietineje Rusijoje: savivaizdis ir imperijos palikimas. Atminties kultūrų dialogai Ukrainos, Lietuvos, Baltarusijos (ULB) erdveje. Sud. Alvydas Nikžentaitis ir Micał Kopczyński. Vilnius: Lietuvos istorijos institutas, 257-275.

Elektroninio Lietuvių kalbos žodyno naujovès. Kalbos kultūra Nr. 85, 92-102. Prieiga internete: http://old.lki.lt/LKI_LT/ images/Periodiniai_leidiniai/Kalbos_kultura/Straipsniai/085/ KK_85_092_102_Naktiniene.pdf

Žodynas - tai abècèlès tvarka išdèstytas visas pasaulis Lietuvoje ir Lietuva visame pasaulyje. Seimo kronika: specialus Nr. 22 (228), 1421. Prieiga internete: http://www6.lrs.lt/kronikos/ pdf/030101/k-22.pdf.

Imperija rusų politiniame diskurse po 1991 metų. Atminties kultūru dialogai Ukrainos, Lietuvos, Baltarusijos (ULB) erdvejje. Sud. Alvydas Nikžentaitis ir Micał Kopczyński. Vilnius: Lietuvos istorijos institutas, 276-289.

Lingvistinès kultūrologijos bruožai. Šiauliai: Vš Šiaulių universiteto leidykla.

Vertybès lietuvio pasaulèvaizdyje. Vilnius: Akademinė leidyba.

Sovietinès cenzūros istoriografija: pagrindinès tyrimų kryptys ir cenzūros sampratos. Knygotyra 69, 84-102. Prieiga internete: https://epublications.vu.lt/object/elaba:24603698/24603698. pdf

Encyclopedic definitions in language dictionaries - a treasure of culture. Logos et Littera: Journal of Interdisciplinary Approaches to Text. Podgorica: University of Montenegro, 28-44.

Išmintis lietuvio pasaulèvaizdyje. Problemos 95, 130-143.

Lietuvių tapatybès kalvé. Vilnius: Aidai.

Lietuvių ir lenkų leksikografijos sąsajos (Związki leksykografii polskiej i litewskiej). Językowe i kulturowe dziedzictwo Wielkiego Księstwa Litewskiego. Red. nauk. Jolanta Mędelska, Zofia Sawaniewska-Mochowa. Bydgoszcz: Wydawnictwo Uniwersytetu im. Kazimierza Wielkiego, 158-166.

„Lietuvių kalbos žodyno“ I ir II tomo ideologinių taisymų nuostatos. Žmogus ir žodis, t. 1, Nr. 5, 63-69. 
Umbrasas, Alvydas. 2019. Valančiauskienè, Aušra. 2019.

Vitkauskas, Vytautas. 2002.

Wnęk, Piotr, BendoraitytèVnęk. 2012.

Zabarskaitè, Jolanta. 2010.

Zabarskaitè, Jolanta. 2012.

Zabarskaitė, Jolanta. 2019.

Žukas, Vladas. 2005.

Aurelija Griteniene

Lietuviu kalbos institutas

P. Vileišio 5, LT-10308 Vilnius, Lietuva

aurelija.genelyte@gmail.com
Terminologija Lietuvių kalbos žodyne. Terminologija 26, 162-183. Enciklopedinès žinios dvikalbiuose žodynuose: geografijos sritis. Verbum 10. Prieiga internete: https://www.zurnalai.vu.lt/ verbum/article/download/16486/15670/27131.

Didysis akademinis mūsų Žodynas. Dvidešimt „Lietuvių kalbos žodyno" tomu. Sud. Jolanta Zabarskaitè, Zita Šimėnaitè, Vilnius: Lietuvių kalbos institutas, 8-14.

Encyclopedic and linguistic information in dictionaries. Daugiakalbystès tyrimai. Sud. Nemira Mačianskienè. Kaunas: Vytauto Didžiojo universiteto leidykla, 82-91.

Politinis pasaulèvaizdis didžiajame „Lietuvių kalbos žodyne“ (valstybè, ịstatymas, valdžia). Parlamento studijos 9, 126-143. Prieiga internete: http://www.parlamentostudijos.lt/Nr9/9_ kalba_1.htm.

Kitoks didžiojo „Lietuvių kalbos žodyno“ skaitymas: Adalbertas Bezzenbergeris, marios, pamarys, pamariškis. Mažoji Lietuva: paribio kultūros tyrimai. Sud. Grasilda Blažienė, Nadežda Morozova, Jolanta Zabarskaitė. Vilnius: Lietuvių kalbos institutas, 239-271.

Rusijos federacijos prezidento V. Putino naratyvų ideologiniai mechanizmai Lietuvos internetinèje žiniasklaidoje. Parlamento studijos 27, 76-118. Prieiga internete: http://www.parlamentostudijos.lt/Nr27/files/76-118.pdf.

Kostas Korsakas: prisiminimai. Vilnius: Ogamas.

\section{KOPSAVILKUMS}

\section{Krievija vārdnīcas Lietuvių kalbos žodynas ilustratīvajos teikumos un nozīmju definīcijās}

\section{Aurelija GRITÉNIENĖ}

Rakstā analizēts, kāds KRIEVIJAS koncepts veidojas no vārdnīcas „Lietuvių kalbos žodynas“ ilustratīvajiem teikumiem un nozīmju definīcijām, kurās pieminēta leksēma Rusija 'Krievija'. Raksta mērḳis ir noteikt, kuras koncepta iezīmes ir vissvarīgākās un kāda varētu būt Krievijas kognitīvā definīcija. Kopumā rakstā analizētas 118 ilustratīvu teikumu un 38 nozīmju definīcijas. Pētījuma materiāls tika savākts no elektroniskās vārdnīcas teksta, neņemot vērā jaunākos pielikumu datus un dialektu kartotēkas, tāpēc jāuzsver, ka iegūtie rezultāti atspoguḷo KRIEVIJAS konceptu, kas veidojies lietuviešu pasaules uzskatā kopš 1917. gada oktobra revolūcijas līdz 21. gadsimtam. Empīriskais materiāls pētīts ar semantisko analīzi, interpretējošo un aprakstošo metodi.

Izpētot ilustratīvos teikumus un nozīmju definīcijas, kurās pieminēta leksēma Rusija, redzams, ka vārdnīca atspoguḷo padomju laika lietuviešu kolektīvo atmiņu. Veidojas reālos 
notikumos balstīts pagātnes apraksts, kuru gadu desmitiem ir stāstījuši daudzi cilvēki (izlokšnu informanti un rakstisko avotu autori), taču šo stāstu ḷoti spēcīgi ir ietekmējusi vārdnīcas autoru un redaktoru (paš)cenzūra.

Vārdnīcas ilustrācijas atklāi vairākas svarīgas KRIEVIJAS koncepta iezīmes. Tā ir liela valsts ar aukstām ziemām, ar līdzenumiem un auglīgu augsni. Viens no svarīgākajiem sava laika politiskajiem notikumiem bija 1917. gada Oktobra revolūcija. Ilustrācijās ir daudz runāts par iedzīvotāju un dažādu tautu migrāciju. No izloksnēs pierakstītajiem teikumiem var uzzināt, ka visbiežāk lietuvieši bēguši uz Krieviju karu dēḷ, daḷa lietuviešu devušies uz šo zemi strādāt, àrstēties vai karadienestā. Izloksnēs pierakstītas arī liecības, ka cilvēki tikuši ar varu izsūtīti uz Krieviju. Ilustrācijās runāts arī par migrāciju pretējā virzienā. Daudzi krievi ieradušies Lietuvā, lai te strādātu vai dzīvotu.

Padomju perioda ilustrācijās ḷoti daudz runāts par marksismu, ḷeņinismu, kapitālismu, komunismu u. c. idejām, minēti tā laika publicistu, filozofu u. c. sabiedrisko darbinieku uzvārdi, politiskās partijas un sociālās grupas, izsmieti kungi, izcelta komunistiskās partijas nozīme, runāts par arvien pieaugošo rūpnīcu skaitu, smagās rūpniecības paplašināšanos Krievijā utt. Daudzi no šiem teikumiem izklausās pompozi, atgādinot saukḷus.

Nozīmju definīciju saturam ir ne mazāka nozīme, formulējot KRIEVIJAS vispārējo konceptu. Definīcijas ir precīzākas: šeit ir norādīti precīzi vēsturiskie datumi, pieminēts vairāk Krievijā dzīvojošo tautu, sociālo grupu, politisko strāvu, kustību un partiju. Krievija ir minēta ar armiju un policiju saistìtu terminu definīcijā un naudas vienību nosaukumos.

Novērots, ka nozīmju definīcijas sniedz precīzus faktus par pētāmo objektu, bet ilustratīvajos teikumos papildus vēsturiskajam naratīvam var pamanīt vairāk subjektivitātes, pat emocionalitātes, kas parasti izpaužas pirmajā personā pierakstītos teikumos.

\section{SUMMARY}

\section{Russia in Illustrative Sentences and Definitions of the Dictionary of the Lithuanian Language}

\section{Aurelija GRITĖNIENĖ}

The article analyses the concept of RUSSIA that can be pieced together from the illustrative sentences and definitions present in the Dictionary of the Lithuanian Language Lietuviu kalbos žodynas that contain a reference to the lexeme Rusija 'Russia'. The goal here is to determine the key attributes of this concept and the possible cognitive definition of Russia. The article covers a total of 118 illustrative sentences and 38 definitions of meanings. Material for the study was screened in the electronic version of the Dictionary, disregarding the latest data available in the card indices of New Additions and Dialects, making it critical to accentuate that the results of the study reflect the concept of RUSSIA that took shape in the Lithuanians' attitude from the 1917 October revolution till the $21^{\text {st }}$ century. Empiric material is scrutinised using the methods of semantic analysis, interpretation, and description.

Analysis of the illustrative sentences and definitions of meanings containing the lexeme Russia shows that the Dictionary provides a reflection of the Soviet period collective memory of the Lithuanians. It projects an account of the past grounded in real events that have been narrated by many people (dialectal informants and authors of written sources) for decades; however, this tale has been heavily influenced by the (self-)censorship of the authors and editors of the Dictionary of that period. 
The illustrations of the Dictionary reveal a number of key attributes of the concept of RUSSIA. It is a vast country with cold winters, flats, and fertile soil. One of the watershed political events of that era was the 1917 October revolution. The illustrations carry a great deal of information about the migration of people and different nations. Dialectal sentences inform us that Lithuanians would often flee to Russia driven by wars; some Lithuanians travelled to that country in pursuit of work, medical treatment, military service. Dialects bear testimony to the fact that people would be taken to Russia by force. The illustrations speak of people moving in the opposite direction as well. There are quite a number of Russians coming from Russia to work or live in Lithuania.

Illustrations from the Soviet period emphasize he ideas of Marxism, Leninism, capitalism, communism, etc., mention the names of publicists, philosophers, and other public figures, political parties and social groups of the era, mock the upper class, elevate the importance of the Communist Party, speak about an ever-growing number of factories in Russia, the expansion of heavy industry, and so on. Some of these questions sound pompous and resemble catchwords.

The content of the definitions of meanings is equally important when it comes to formulating the overall concept of RUSSIA. The definitions of meanings carry a higher degree of specifics, indicating precise historical dates, mentioning more nations living in Russia, as well as political trends, movements, and parties. Russia is referred to in definitions of terms relating to the military and the police, as well as the names of monetary units.

It has been noted that the definitions of meanings provide precise facts pertaining to the subject of the study, while illustrations, apart from the historical narrative, possess a higher degree of bias and even emotion, which is usually expressed through sentences written in first person. 



\title{
MIHALA JANA BORHA DZEJOJUMS „VARAKḶĀNU PILS JŪTU DĀRZS“ (JARDIN SENTIMENTAL DU CHÂTEAU DE WARAKLAND, 1795) APGAISMĪBAS LITERATŪRAS KONTEKSTĀ
}

\author{
Māra GRUDULE \\ Latvijas Universitāte
}

\section{Ievads}

1795. gadā Varšavā franču valodā nāk klajā Mihala Jana Borha (vācu Michael Johann von der Borch-Lubeschitz und Borchhoff, poḷ Michał Jan Borch, 1753-1810) sacerējums Jardin sentimental du château de Warkland. Simonas Sofijas Valkes tulkojumā un Māra Salēja lieliskā atdzejojumā to ir iespējams lasīt arī latviski ${ }^{1}$ — „Varakḷānu pils jūtu dārzs“ 2019. gadā franču oriǵinālā un tulkojumā ir publicēts ar Latvijas Nacionālās bibliotēkas projekta „Neredzamā bibliotēka“ finansiālu atbalstu. Nelielais, pat pirmajā acu uzmetienā - necilais - kabatas formāta izdevums iemieso pagāiuša, bet aizraujoša laikmeta pēdas (Borch 2019).

Pēc 1790. gada, atgriezies no Eiropas celiojumiem, un iespējams, arī saguris no diplomātiskajām spēlēm, Borhs apmetas uz pastāvīgu dzīvi Varaklānu pilī un kopā ar itālu arhitektu Vinčenco de Macotti (Vincenzo de Mazotti, 1756-1798) turpina darbu pie savas pils un parka iekārtojuma. Borha dzejojums un ieceres realizācija Varakḷānos gan ir divas atškirīgas pasaules. Dzejojums, kā pats autors atzīst, ir ,alegorija“ (Borch 2019: 15), kurā plašais ūdens klajs pils priekšā ir „cilvēka dzīves okeāns“ (Borch 2019: 15), un no šîs vietas sākas arī ceḷojums , jūtu dārzā“.

Mihals Jans Borhs, Polijas Lietuvas galma aprindām pietuvināts labi izglītots dabaspētnieks, celatotājs un diplomāts, ir mazliet arī dzejnieks. Viņa „Varakḷānu pils jūtu dārzu“ mēdz dēvēt par labāko, ko Borhs ir sacerējis. To iespējams uzlūkot kā ceḷvedi pastaigā pa parku. Kamēr Borha varonis jaunais aristokrāts (sic! Franču revolūcijas vēsmas viņu nav skārušas) mēro ceḷu no viena parka objekta līdz nākamajam, stāsts rit rāmā prozas valodā, savukārt vēstịjumi uz tajā izvietotajām plāksnēm, bluḳiem, mūriem un citiem objektiem ir lasāmi dzejā, tie veido galveno un garāko sacerējuma daļu. Tie

2019. gada sākumā publicēts vēl viens Borha dzejojuma tulkojums (Borhs 2019: 60-75). Salēja un Jēkabsones-Valteres latviskojumu salīdzinājums sniedz labu priekšstatu par to, kāda nozīme ir dzejnieka talantam un kāda - tulkojuma precizitātei. 
aicina izskaust sevī netikumus un cildina morālās vērtības un kalpošanu vispārējam labumam, tēvzemei un nācijas interesēm kā augstāko tikumu.

\section{Libertīnu romāni un moralizējošā literatūra}

Gandrīz vienlaikus ar Mihala Jana Borha sacerējumu Francijā nāk klajā libertīna marḳiza de Sada (Donatien Alphonse François, Marquis de Sade, 1740-1814) romāns ,Justīne jeb tikumības nedienas“ (Justine ou Les Malheurs de la vertu, 1791²). Dažā ziņā arī to var uzlūkot kā ,jūtu dārzu“. Ar galvenās varones Justīnes, romānā arī - Terēzes, starpniecību de Sads izvadā lasītāju cauri dažādām izvirtušu vīru seksuālo org̣iju epizodēm pilīs, pilsoniskos namos un klosteros, atklājot miesas kaislību bezdibeņus, kas nereti augstāko punktu sasniedz savu upuru baisāko ciešanu brǐžos. Romāna sižetu veido Justīnes cel̦š no vienas epizodes līdz nākamajai. Atškirīībā no apgaismības laikmeta libertīnu romānu vairuma, kuru darbība risinās urbānā vidē, de Sads liek savai varonei galvenokārt klīst pa mežiem, laukiem un plavām. Visbiežāk nejauša noklīšana no ceḷa, apmaldīšanās biezoknī un nakšņošana zem krūmiem, slēptiem gāiēju acīm, ir iemesls tam, lai nokḷūtu kārtējo mocītāju rokās. Mežs un biezoknis, citiem vārdiem - nekultivētā vide, labi sasaucas ar libertīnu neapvaldītajām kaislībām. Antropologs Tomas Vīns libertīnu romānus raksturo kā ,savdabīgu audzināšanas romāna formu, kurā jaunais varonis vai varone tiek iepazīstināti ar pasaules realitāti. Šì galvenokārt ir erotiska rakstura izglīīiba“, atzīst Vīns, ,viena no 18. gadsimta atslēgas mācībām par seksuālo baudu kā prāta un ķ̣ermeņa atbrīvotāju“ (Wynn 2011: $416)^{3}$. Borha un de Sada gandrīz vienlaikus tapušie darbi atklāj apgaismības literatūras divas puses. Tajā libertīnu romāni un morālistu sacerējumi veido pretstatu pāri, tomēr kā viens tā otrs - kā brālis un māsa pieder jaunajai laikmetīgajai literatūrai. Tie kopā rada jaunu domas un rakstniecības veidu, kas iemieso galvenokārt sekulāru skatīijumu uz cilvēka dabu un viņa morālo dzīvi (Méchoulain 2017: 229).

Borha sacerējums gan liecina, ka arī viñam pašam cilvēciskās kaislības nav svešas. Bet Borhs ir estēts. „Varakḷānu pils jūtu dārza“ sākumdạ̣ā autors pārlūko mākslas darbus, kuros attēlotas grieķu un romiešu mītu epizodes.

2 Arī de Sada romāns lasāms latviski: Marķīzs de Sads. Justīne jeb tikumības nedienas. A. Skrābanes tulkojums. Rīga: Jumava, 2007.

3 [..] the libertine novel takes the form of the Bildungsroman, whereby the young hero or heroine is educated to the realities of the world. This education is primarly of an erotic nature, and it is one of the 18th' century key lessons that sexual pleasure, devoid of the stain of sin, can liberate the mind as well as body. 
Aiz dailo mākslu un tajās ietverto mītu plīvura slēpjas incests brāla un māsas, un tēva un meitas starpā, pavešana, izvarošana un ārpus laulības sakari. Tie attēloti apgaismības laikmeta izglītotajam lasītājam labi zināmos Rubensa, Ticiāna, Korredžo, Rembranta, Delvo, Rīlanda un citu mākslinieku darbos. Tā, piemēram, Borhs raksta: „Ar meitu Kinirs laižas pretdabiskā dēkā, / Par to, ka savu meitu glāsta, aizmirstot“" (Borch 2019: 9), kā zināms, Kinira sakars ar savu meitu Mīru beidzas ar viņas pārvēršanu par koku un Adonīsa piedzimšanu. Šo epizodi savā gleznā 1690. gadā izmantojis itāḷu baroka meistars Markanto Fransešīni savā gleznā. Savukārt Borha pieminētā Lapitu valdnieka Îksona iekāre pret dievu sūtīto viltus Hēru jeb Junonu un Semeles nāve, ieraugot Jupiteru (Borch 2019: 7-9), skatāmas Rubensa gleznās; Ledas un Zeva jeb gulbja motīvs (Borch 2019: 9), no kura vinai piedzimst divi bērni, atklāts Borha laikabiedra iepriekš minētā Viljama Vīna Rīlanda gravīrā. Borha pieminētā Biblīda, ,kas krīt ar brāli asinsgrēkā“ (Borch 2019: 9), iedegas kaislē pret savu dvīṇu brāli Kauno. Biblīda un Kauno ir attēloti apgaismības laikmeta mākslinieka iepriekš minētā Lorensa Delvo figurālajā veidojumā. Borha pieminēto Pomonu (Borch 2019: 9) paved viņas topošais vīrs, tuvojoties tai kā siena plāiēejs un kā gans, kā abolu lasītājs un karavīrs, kā zvejnieks un veca sieva, tas vēršas par vīnogu šḳ̂ēēm Pomonas rokās un galu galā viņu arī iegūst. Atsauce uz šo mītu skatāma Dāvida Teņiēra Vecākā gleznā „Vertumns un Pomona“"4.

Tomēr kavēties pie kaislību tēlojuma, nav Borha mērķis: „Vai dievus netikḷus, kas vilt un krāpties prot, / Par labu paraugu mums nāktos uzlūkot? [..] Vai māksla blāvāka, ja tajā tikumiem / Ar veiklu kaltu mākslinieks prot godu dot?“ (Borch 2019: 9). Piesaucot kara dievu un trīs dūšīgus romiešus, kas bijuši gatavi ziedot savu dzīvību par tēviju - un ,tēvija“ būs atslēgas vārds arī dzejojuma beigās - Borhs noslēdz atskatu pagātnē un vedina lasītāju doties „dārzā vienkāršā, ko daba apglezno“ (Borch 2019: 11).

\section{Jauna aristokrāta rokasgrāmata}

„Varakḷānu pils jūtu dārza“ sižets vijas ap pastaigu. Kā raksta vācu literatūrzinātniece Ulrike Plāta: „,18. gadsimta otrajā pusē pie vispār atzītākajām pasaules iepazī̌anas formām piederēja tieši ķermeniska un jutekliska apkārtējās vides pieredze, kas iegūta, uzturoties dabā. Ja iepriekšējos laikos celojuma mērksis bija izglītības centri vai izslavēts meistars, tad ap 1800. gadu ceḷš līdz mērksim un kustība vidē pati par sevi bija daḷa no kognitīvā mācību

4 Visi iepriekš minētie mākslas darbi bez pūlēm atrodami tīmeklī. 
procesa. [..] ceḷojuma literatūras autoram bija jābūt sinestēzistam, gleznojot un komponējot ainavu ar vārdiem“ (Plath 2011: 78, 80)5. Arī Borhs liek savam jaunajam aristokrātam un ar viņa starpniecību - arī lasītājam redzēt, saklausīt un izdzirdēt pasauli - to atklāt ar visām maņām. Tomēr dzirdes, redzes un ožas kairinājums kalpo tikai kā atgādne par bīstamību, ko sevī slēpi jutekḷi. Kaislība nomāc prātu un iemidzina tikumus. Borhs raksta: ,jauneklis iestumj laivu uz baudu salas pusi [..] ūdeņi ar mağisku atbalsi dubulto tās valdzinājumu [..] salda smarža apņem, rozes, savijušās ar jasmīniem un sausseržiem, tūkstošiem ziedu nosēts zāliens, jaunā ceḷotāja maņas tiek maigi kairinātas - rezēda un smaržīgā vanila [..] aicina l̦auties baudai““ (Borch 2019: 19, 21). Tas viss ved maldu ceḷos. No kāda ziedu groza izlien čūska, baudkāras sievas acu skatiens ir miegains, blāvs un garlaikots, jaunais varonis nepatikā novēršas.

Viss turpmākais ceḷš ir veltīts mācībām no uzrakstiem uz ceḷā aplūkotajiem pīlāriem, lapenēm, tempḷiem, drupām, marmora bluķiem, kolonnām, eremīta būdas sienas, antīka portāla, pieminekḷa, piramīdas, plāksnes un tā joprojām. Pretī kaislībai tiek likta mīla laulībā, cieņa un gods, pretī mizantropijai, paštaisnumam un skaudībai - draudzība un tikumība, pretī depresīvām nāves domām - ticība mūžīgai gaismai. Augstā stila rindas papildina laba deva teatrālisma un eksaltācijas. Borhs liek savam varonim „,mesties ceḷos“ (Borch 2019: 49), „pilnam bijības lūgties“ (Borch 2019: 49), ,,dot zvērestus“ (Borch 2019: 59) un „sildīt krūtīs paklausības, cieņas uzticības, aizrautības un paklāvības jūtas“ (Borch 2019: 59). Jaunais aristokrāts ceḷojumu noslēdz pie Tikuma un Slavas templịem ar piemiņas zīmēm vietvaldim Vidzemes generālgubernatoram un vienlaikus arī Borha sievastēvam Georgam fon Braunam (Georg Reichsgraf von Browne, 1698-1792) un Krievijas carienei Katrīnai II Lielajai (Ekaterina II Velikaja, 1729-1796), viņas dēlam Pāvelam Petrovičam (Pavel I Petrovič Romanov, 1754-1801) un vedeklai Marijai Fjodorovnai (Marija Fedorovna, 1759-1828). ,Jo tikumu tikums ir nesavtīga ziedošanas vēlme nācijas kopējām interesēm un tiem, kas ir nomodā par šīs cēlās un varenās impērijas labklājību“ (Borch 2019: 61), raksta Borhs. Patoss sasniedz augstāko pakāpi un tā piederas, tāda ir laikmeta mode. Salīdzinājumam — kad 1782. gada novembrī Rīgā viesojas iepriekš minētie

5 In der zweiten Hälfte des 18. Jahrhunderts gehörten direkte körperliche und sinnliche Umwelterfahrungen, gesammelt bei Aufenthalten in der Natur, zu den allgemein beliebten Formen der Weltaneignung. (..) Während in früheren Zeiten die Ausbildungsstätten oder Meister das Ziel der Wanderschaft waren, wurden um 1800 der Weg zum Ziel und die Bewegung in der Umwelt zu einem Teil des kognitiven Lernprozesses. (..) Die Reiseschriftsteller hatte Synästhesist zu sein, hatte Landschaften mit seinen Worten zu malen und zu komponieren. 
Pāvels Petrovičs un Marija Fjodorovna, Borha sievastēvs reihsgrāfs fon Brauns sarīko viesiem cien̄̄gu uzņemšanu: Klīversalā tiek celti goda vārti, pie Rīgas rātsnama ir novietota goda kolonna, savukārt g̊enerālgubernatora pils priekšā īpaši šim svinīgajam gadījumam ir izveidots Goda templis, balstīts uz korintiešu kolonnām, apvìts ar ziedu vītnēm un izgaismots. Tā vidū ir Prieka altāris. Virs altāra laistās ugunīgi vārdi: „Pāvels Petrovičs“ un „Marija Fjodorovna“, tos papildina vizulojojošs uzraksts dzejā. Blakus altārim ir izvietotas Minervas un Cerības statujas, tempḷa ieeju grezno Tikuma, Mīlestības, Pastāvības un Pilnības vāzes un Cēzara, Augusta, Tita Flāvija Vespasiāna, Titus, Marka Aurēlija un Konstantīna krūšutēli. Vakarā, protams, ir sarīkota ugunošana. Kā raksta Rīgas vācu avīze, „gavilējošais [lạužu] pulks ar laimes vēlējumiem sāka svinēt mūsu prieka dienas svētkus“ (Anon. 1782: 8) ${ }^{6}$.

\section{4. „Varakḷānu pils jūtu dārza“" konteksti: dārzkopība}

18. gadsimta otrajā pusē Eiropas dārzu un parku kultūrā notiek pāreja no franču barokāli simetriskajiem dārziem uz angḷu ainavu parkiem. Žana Žaka Ruso (Jean Jacques Rousseau, 1712-1778) idejās ieklausīiies, apgaismotais cilvēks mācās saskatīt skaisto dabiskajā, upes ielokos, p̣̣avu un mežu ainavās, ezeru salās un pakalnos savas pils vai muižas apkārtnē. Saplūst jēdzieni „ainava“ un „dārzs“, izveidojas jauns profesionāḷa apzīmējums — „ainavu dārznieks“. Izglītotajam piederas ne tikai grāmatu, mākslas darbu, minerālu, putnu ādiṇu un izbāzeņu krāšana, kas vienlaikus ceḷ arī to īpašnieka prestižu, bet parku un stādījumu iekopšana. Itālijas celıjojumiem nākot modē, dārzkopībā dominē t. s. Augusta stils - Romas imperatora Augusta laikmetam (27.-14. p. m. è.) raksturīgā klasiskā ainava ar statujām, grotām, templiem, tiltiem ar pārsedzēm un jumtiniem, iedvesmu gūstot no renesanses arhitekta Andrea Palladio (Andrea Palladio, 1508-1580), grieķu un romiešu kultūras cienītāja, darbiem. Dabā izvietotie arhitektūras objekti, kurus 18. gadsimta otrās puses dārzkopības literatūrā dēvē par fabriqué jeb 'cilvēka roku darinājumiem', stāsta par pagātni, par svešzemju kultūru, vēsturi, mākslu, rada asociācijas un sniedz garīgu baudu, papildinot pastaigas prieku. Dabisko ainavas skaistumu iemieso arī zemnieku saimniecības un tām piederīgās ganības, šķūņi, klētis un dzirnavas. Ķīles universitātes profesors Kristiāns Kejs Lorencs Hiršfelds (Christian Cay Lorenz Hirschfeldt, 1742-1792) publicē dārzu dizaina teoriju piecos sējumos Theorie der Gartenkunst (1779-1785), iesakot

6 [..] die frohlockende Menge die Feyer unserer Freudentage unter Segenswünschen begieng. 
vāciešiem, iedvesmojoties no franču baroka dārza un angḷ ainavu parka, radīt pašiem savu - vācisko dārzu (Kluckert 2000: 406). Ja Anglijā baroka dārzus kā novecojušus un laikmeta modei neatbilstošus posta, tad vācu zemēs tos uzlabo un modernizē (Turner 2011: 294-295). Hiršfelds augstu vērtē angḷu emocionālo dārzu, norādot, ka dārzs nav domāts tikai acu priekam, bet tas arī rosina fantāziju ar savu vērienu, melanholijas, prieka un cēlā izjūtu. Parks piedāvā iespējas sentimentālai jūsmai - tempḷi un memoriāli ar uzrakstiem svin draudzību, mīlestîbu, uzupurēšanos, dzirnavas, ganībām atvēlētās pḷavas, šķūn̄̄ši un zemnieku mājas idealizē lauku dzīvi, iedveš mieru un harmoniju (pēc Benn 1991: 13). Starp citu, Baltijas kultūrvēsturnieks Johans Kristofs Broce (Johann Christoph Brotze, 1742-1823) Inčukalna muižā 1801. gadā ir atradis pieminekli Hiršfeldam un to uzzīmējis, pievienojot arī uz tā lasāmo uzrakstu: „Hiršfelda pieminai 1799. gada 24. jūnijā. Šajā parkā, kuru pa pusei radīja fantāzija, pa pusei daba, kur zaḷas ēnas savienojas ar strauta čalošanu, lai pie Hiršfelda pieminekḷa lauku dabas draugam nekad netrūktu dvēseles miera, ko viņš mums mācịja meklēt un baudīt klusā vietā“" (Broce 2002: 133). Līdzịgi kā Borha sacerējumā, arī šajā paīsajā vēstījumā uzmanība veltīta gan maņu - redzes un dzirdes - vingrināšanai, gan refleksijai: Broces zīmējumā redzams arī sūnu un velēnu sols atpūtai un pārdomām.

Ang̣̣u ainavu dārza tradīcija 18. gadsimta otrajā pusē nostiprinās arī Polijā ar Sīmona Bogumila Cuga (Szymon Bogumil Zug, 1733-1807), viena no lielākajiem apgaismības arhitektiem, starpniecību. Par angḷu dārziem kā Vidzemē vispopulārāko dārza veidu raksta Heinrihs Johans fon Jannavs (Heinrich Johann von Jannau, 1753-1821; Jannau 1781: 65), tos slavē arī Augusts Vilhelms Hūpels (August Wilhelm Hupel, 1737-1819) savā „Ekonomiskajā rokasgrāmatā“" (Hupel 1796: 256). Prasmīgi iekoptu dārzu vai muižas parku var salīdzināt ar atvērtu grāmatu, ar enciklopēdiju vai pat ar veselu bibliotēku - katra jauna objekta iepazīšana un uzrakstu lasǐšana līdzinās lapas pāršķiršanai, tempḷi ir papildināti ar citātiem, kolonnas - ar norādēm, piemiņas akmeņi - ar dzejoḷiem.

Baltijā 18. gadsimta otrajā pusē pārejas posmu no baroka dārza uz ainavu parku labi raksturo t. s. izpriecu mežiņi ar celiņiem pastaigām, kuru krustpunktos novietoti obeliski, stēlas, vāzes, urnas ar soliņiem meditācijai. Šāds mežiņš ir bijis Bīriņos, domājams arī Drustos, Ulbrokā, Jāṇmuižā pie Cēsīm un citur. Kādā Karla Gotharda Grasa (Karl Gotthard Graß, 1767-1814) zīmējumā ir redzama birzīte Strazdumuižā, t. s. Dorotejas līksme7 . 1791. gadā

7 Dorotejas līksmes, orig̣inālā Dorotheens Lust nosaukums cēlies no tā brīža muižas īpašnieka atraitnes Dorotejas fon Fromholdes vārda. 
tajā ir atradies piemineklis, uz kura četriem sāniem bijuši uzraksti vāciski, latviešu tulkojumā uzraksti vēstītu: „Pēc sava drauga / aicinājuma šeit / brālīgi rokās sadevās / daba un māksla“; „Draudzība šo vietu / lēma tīkamam laika kavēklim / un nosauca to par Dorotejas līksmi“; „Lai sveicināts ikviens, / kas ar prātu bauda un / nevis postot traucē / vēlā svētceḷnieka priekus“ un „Prātīgam priekam, / sirsnīgai draudzībai, / pašapcerei vienatnē“ (Broce 1996: 129). Nezināmais autors ir izmantojis tos pašus atslēgas vārdus, kurus atrodam arī Borha sacerējumā.

Jauku liecību par Kurzemes parkiem Meženieku, Vormsātu, Izriedes, Lielbērzes un Virkus muižās, ar un bez apskates objektiem un ainavu lieliski greznojošām zemnieku saimniecībām devis Baltijas vācu dzejnieks Ulrihs fon Šlipenbahs (Ulrich von Schlippenbach, 1744-1826) darbā „Gleznieciski ceḷojumi Kurzemē“ (Schlippenbach 1809). Tātad Borha laikā ne Kurzemē, ne Vidzemē nav trūcis muižiņu, kuru apkārtnē bijušas mākslīgas pilsdrupas, vientuḷnieku namiņi, urnas, obeliski, romantiskas grotas, piramīdas un tempḷi un pamazām šì mode sasniegusi arī Latgali. Lielu ainavu parku Vidzemes ziemeḷdaḷā - Alūksnē no 1795. līdz 1830. gadam iekārto Kristofs Burkards fon Fìtinghofs-Šèls (Christoph Burkard von Vietinghoff-Scheel, 1767-1829), izmantojot tam l̦oti pateicīgo reljefu - pakalnus, ezeru un salas. Kā norāda mākslas vēsturnieks Ojārs Spārītis, „Alūksnes parka ansamblis [..] sniedz visplašāko mitolog̣ijas, alegoriju un personifikāciju diapazonu Latvijas parku mākslā“ (Spārītis 1998: 29). Tā radīšanas laikā parkā bijusi oranžērija ar skulptūrām, Saules templis kā rezonators ar vēja dievam Aiolam veltītu aprīkojumu melanholiska rakstura skaņu ienesumam, Dianas skulptūra uz postamenta, Pomonas templis, kīniešu paviljons, obelisks, paviljons ar piramidālu jumtu Krievijas caram Aleksandram I un citi objekti (Spārītis 1998: 28, 41).

\section{Mihals Jans Borhs, iespējamie ietekmju avoti un atskaņas}

Šodien neiespējami pateikt, no kā tieši Mihals Jans Borhs, radot savu sacerējumu par Varakḷannu pils jūtu dārzu, ir ietekmējies. Viņš ir cēlies no Baltijas vācu dzimtas, tomēr dzīves laikā sevi pozicionējis kā poli un krietnu dzīves sprīdi pavadīịis Polijas - Lietuvas lielvalsts galmā, dzīvojis Varšavā, bet viesojies Saksijā, Šveicē, Francijā, Sicīlijā un Maltā, Holandē un Lielbritānijā, un visbeidzot atgriezies Varakḷānos. Ikdienā grāfs Borhs sazinājies un rakstīịs poliski, vāciski, apguvis angḷu un itāḷu valodu, dzejojis franciski, itāliski un nedaudz arī - latviski (Taimiņa 2013: 6). Kā atzīst kultūrvēsturnieks Kaspars Klaviņš: „,Borhu dzimtā patriotisms ir daudzpakāpju pārreǵionāls 
jēdziens, orientējoties pēc Eiropas vērtību skalas [..] Borhs bija ārkārtīgi veikls diplomāts, apveltīts ar labu intuīciju un spēju sasniegt iecerēto mērkịi, par spīti jebkuriem šksēršliem, neatpaliekot no sava laika ironiskajiem franču un itāḷu avantūristiem, kas noteica izturēšanās stilu 18. gadsimta II puses Eiropā““ (Kḷaviņš 2013: 89). Poḷu mākslas zinātniece Jolanta Polanovska (Polanowska) Varakḷānu pils faktiskajā dārzā un Borha dzejojumā saskata ietekmes no angḷu kultūras - no Stovas (Stowe) ainavu parka Bekingemšīrā (Buckinghamshire). Tas 18. gadsimta otrajā pusē ir bijis viens no populārākajiem pastaigu mērkiiem Eiropā. 1754. gadā Stovu apmeklējis arī vēlākais Mihala Jana Borha paziņa Polijas karalis Stạ̧islavs Augusts Poņatovskis (Stanisław August Poniatowski, 1732-1798) (Polanowska 2013). Starp citu, arī Stovas īpašnieks Ričards Templs (Richard Temple, 1675-1749) parka apskatei ir izstrādājis ceḷvedi, tomēr atšksirībā no Borha, tikai īsi informējot par parkā redzamajiem objektiem un iztiekot bez poētiskiem papildinājumiem un alegorijām (Temple 1751). Polanovska līdzības saskata gan Borha pils un Stovas pils parka izvietojumā, gan Varaklạnos plānotajā, gan Stovā izvietotajā tempḷu skaitā - pieci un astoņi, gan abiem parkiem raksturīgajā eremīta namiņā, gan nacionālu varoṇu godināšanā - Borha poēmas sākotnējā iecerē tie ir izcili poḷi, laikmeta vēsmām mainoties - poēmas gala variantā Krievijas valdniece Katrīna Lielā un viņas g̊imenes locekḷi. Gan Stovā, gan Borha pils parka dziļumos ir piramīdas, kas godina arhitektu piemiņu. Abos parkos ir arī pieminekḷi pils īpašnieku suņiem. Tomēr jāatzīst, ka visi iepriekšminētie ir arī tradicionāli šā laikmeta kultūras objekti. Tikpat labi var saskatīt līdzību starp Borha cildinājumu Georgam fon Braunam un uzrakstu uz obeliska fon Fìtinghofam Alūksnes parkā, vai starp dzejojumā pieminēto apbedījumu vietu — „hieroglifiem klātu piramīdu“ (Borch 2019: 41) ar „pazemes velvēm ar nišām“ (Borch 2019: 41) un mākslas vēsturnieka Imanta Lancmaņa aprakstītajām kapenēm Dunalkā - piramīdas formā ar cilindrisku telpu, kuras mūros trīs rindās likts pa 14 radiālām nišām zārku novietošanai. Mūsdienās no tā visa ir saglabājušās drupas (Lancmanis 1998: 54).

Iespējams, Borhs patiešām ir iedvesmojies no Stovas, lai gan nav ziņu, vai viņš tur vispār ir bijis. Nav arī neiespējams, ka ceḷojums cauri Varakḷānu pils fantāzijas parkam ir dažādu iespaidu un Borha paša radīto priekšstatu veidots, iedvesmu gūstot no ārzemēs redzētā.

Sentimentālā un t. s. izpriecu dārza mode 19. gadsimtā pamazām zaudē savu lomu kā nedabiska un ārišksīga (Benn 1991: 13-14). Tomēr no Borha laikmeta - no 18. gadsimta beigām līdz mūsu dienām - vienā otrā Latvijas muižas parkā kaut kas ir vēl saglabāiies: joprojām iespējams apskatīt mākslīgās pilsdrupas un eremītu lūgšanu kapelu Jumpravmuižā. Un noteikti ir vērts 
doties uz Alūksni, lai iepazītu turienes plašo ainavu parku ar fon Fītinghofu sarūpētajām mazajām arhitektūras formām. Apskatei ir atvērta arī pati Varakḷānu pils. Iespējams, tur gūtais iespaids būs vēl spēcīgāks pēc Mihala Jana Borha „Varakḹanu pils jūtu dārza“ lasīšanas.

\section{Literatūra}

Anon. 1782.

Benn, Sheila Margaret. 1991.

Borch, Michal Jan. Borhs, Mihals Jans. 2019.

Borhs, Mihals Jans. 2019.

Broce, Johans Kristofs. 1996.

Broce, Johans Kristofs. 2002.

Hupel, August Wilhelm. 1796.

Jannau, Heinrich Johann. 1781.

Klaviņš, Kaspars. 2013.

Kluckert, Ehrenfried. 2000. Lancmanis, Imants. 1998.

Méchoulain, Eric. 2017.

Plath, Ulrike. 2011.

Polanowska, Jolanta. 2013.

Schlippenbach, Ulrich von. 1809.
Vermischte Nachrichten. Rigische Anzeigen 47. 21. Nov.

Pre-Romantic Attitude to Landscape in the Writings of Friedrich Schiller. Berlin, New York: W. De Gruyter.

Jardin sentimental du château de Warkland. Varaklānu pils jūtu dārzs. Tulkojuši Māris Salējs un Simona Sofija Valke. Rīga: Latvijas Nacionālā bibliotēka.

Varakḷānu pils sentimentālais dārzs, Borhu grāfistē Baltkrievijā. Tulkojusi Valda Jēkabsone-Valtere. Kultūrainava: tās saturs, uztvere un transformācijas. Dārzu un parku kultūra Baltijas valstīs un Eiropā. Rīga: Medicīnas apgāds, 60-75.

Zìmējumi un apraksti. 2. sēj. Rīga: Zinātne.

Zìmējumi un apraksti. 3. sēj. Rīga: Zinātne.

Oekonomisches Handbuch für Lief- und Ehstländische Gutsherren wie auch für deren Disponenten. Erster Theil. Riga: J. F. Hartknoch.

Sitten und Zeit: ein Memorial an Lief- und Estlands Väter. Riga: J. F. Hartknoch.

Mihaela Johana Borha tikšanās ar Voltēru - Latvijas kultūras vēstures eiropeiskā lappuse. Latvijas Vēstures Institūta Žurnāls 4. 80-97.

European Garden Design, Cologne: Könemann.

Iznīcības simboli un romantisms. Grosmane, Elita (sast.). Romantisms un neoromantisms Latvijas māksslā. Rīga: Izdevniecība AGB, 42-61.

From Moralists to Libertines. C.Prendergast (ed.). A History of Modern French Literature from the sixteenth century to the twentieth century. Princeton University Press, 229-249.

Sinneslandschaften. Die Bedeutung der Sinne bei der Beschreibung baltischer Landschaften und Kulturen (1750-1850). L. Lukas, U. Plath, K. Tüür, J. Undusk (Hrsg.). Umweltphilosophie und Landschaftsdenken im baltischen Kulturraum. Tallinn: Underi ja Tuglase Kirjanduskeskus, 74-109.

Michal Jan Borch and his rezidence in Varaklāni. Mākslas Vēsture un Teorija 16. 18-32.

Malerische Wanderungen durch Kurland. Riga und Leipzig: C. J. G. Hartmann. 
Spārītis, Ojārs. 1998.

Taimiņa, Aija. 2013.

Temple, Richard. 1751.

Turner, Tom. 2011.

Wynn, Thomas. 2011.
Romantisma tēlu sistēmas semantika Latvijas muižu parku arhitektūrā un tēlniecībā. E. Grosmane (sast.). Romantisms un neoromantisms Latvijas mākslāa. Rīga: Izdevniecība AGB, 28-41.

Borchiana versus Siciliana. Grāfa Borha Sicīilijas ceḷojums un tā reminiscences. Mākslas Vèsture un Teorija 16. 5-17.

Stow: The gardens of the Right Honourable the Viscount Cobham. Buckingham: B. Seeley.

European Gardens. History, Philosophy and Design. London, New York: Routledge.

Libertinage. W. Burgwinkle, N. Hammond, E. Wilson (eds.). The Cambridge History of French Literature. Cambridge: Cambridge University Press, 412-419.

\author{
Māra Grudule \\ Latvistikas un baltistikas nodala \\ Humanitāro zinātņu fakultāte \\ Latvijas Universitäte \\ Visvalža iela 4a, Rīga, Latvija \\ mara.grudule@latnet.lv
}

\title{
SUMMARY
}

\section{Jardin sentimental du château de Warkland (1795) by Michał Jan Borch in the Contexts of Enlightenment Literature}

\author{
Māra GRUDULE
}

The article provides an insight into the literary and cultural-historical contexts of Michał Jan Borch's poem Jardin sentimental du château de Warkland, published in Warsaw in 1795. Borch's poem enters the literary space almost simultaneously with the most remarkable libertine novel by Marquis de Sade Justine ou Les Malheurs de la vertu (1791). Both texts, although opposite in content - one emphasizes the need to cultivate virtues, the other reveals the most unattractive aspects of human nature - reflect the Enlightenment's interest in the inner world of a man - desires, passions and moral virtues. The chosen study method a thematic walk in nature from one instructive sculptural object to the next - corresponds to Enlightenment didactics - knowledge can be acquired by moving in nature, through physical and sensual adventures, as well as reflecting on the objects seen on the way. Pathos-filled style commemorating political figures echoes the ambitious enunciations in the Baltic press about the anniversaries and visits of European rulers. The description of the garden of Borch's Varaklāni castle reflects a characteristic passion for the creation of gardens and landscape parks: the garden enchanted by the author's fantasy corresponds to the model of gardens and landscape parks all over Europe, including the Baltic, at the turn of the 18th and 19th centuries, e.g. the Stowe Garden in England, the landscape garden around Alūksne castle in Vidzeme, and the Meženieki, Vormsāti, and Izriede palace gardens in Kurzeme. 


\title{
STĀRKISIS (VĀCU STORCH) LATVIEŠU VALODAS LEKSIKOGRĀFISKAJOS AVOTOS
}

\author{
Ilga JANSONE \\ Latvijas Universitāte
}

\section{Ievads}

Latviešu valodas senās vārdnīcas sniedz ziņas ne tikai par valodā sastopamajām leksēmām, bet lielākoties arī norāda uz atbilstošu parādību, priekšmetu, dzīvu būtņu izplatību tagadējās Latvijas teritorijā. Jēdzienu stārķis (vācu Storch) apzīmējošas leksēmas sastopamas jau pirmajos leksikogrāfiskajos avotos, bet par šā putna ligzdošanas vietām un izplatîbu Latvijas teritorijā ir daudz neskaidrību.

\section{Informācija par stārḳi ornitologiskajās publikācijās}

Biolog̣ijas doktore ornitolog̣e Māra Janaus norāda, ka „Latvijā baltie stārḳi nav dzīvojuši vienmēr. Viṇu dzīvei nepieciešamas plašas, atklātas ainavas ar daudzām mitrām teritorijām - ezeriem, dịkiem, applūstošām plạavām un upju palienēm, kā arī zemnieki, kas, apstrādājot zemi, rada stārḳim labas iespējas iegūt barību [..] Pašās pirmajās publikācijās par putniem Latvijas teritorijā (18. gs. beigas - 19. gs. sākums) tiek pieminēts gan baltais, gan melnais stārkisis, bet nav ziņu par to izplatību un skaitu. Toties jau 19. gs. vidū vairāki pētnieki situāciju apraksta diezgan līdzīgi, proti: agrāk baltie stārḳi esot ligzdojuši tikai Kurzemē, to izplatības ziemeḷu robeža stiepusies gar Daugavu, bet 19. gs. pirmajā pusē putnu skaits strauji pieaudzis, tie sākuši ligzdot visā tagadējā Latvijas teritorijā.“ (Janaus 1999: 20, 22)

M. Janaus secina, ka „baltie stārķi Latvijā ir samērā neseni ienācēji. Vietējie, aborigēni, ir melnie stārķi, kuri vienmēr dzīvojuši mežos, un Latvija, kā zināms, ir bijusi un joprojām ir mežu zeme.“ (Lavrinoviča 2016) Melnais stārķis Baltijas reǵiona putnu sarakstos minēts jau 18. un 19. gadsimtā; tā izplatība raksturota gan kā reta, gan piemērotos biotopos bieži sastopama (Janaus 1995: 217-218).

Ielūkojoties vienā no senākajiem 18. gadsimta pêtījumiem par Vidzemes dabu - Jakoba Benjamina Fišera (Jacob Benjamin Fischer; 1731-1793) darbā „Versuch einer Naturgeschichte von Livland“, redzams, ka gārņu dzimtā (Reiher; Ardea L.) ietilpst gan baltais stārķis (Storch. A Ciconia. L. 84.7), gan melnais stārķis (Schwarzer Reiher A. nigra L. 84.8), bet kopīgā dzimtas 
aprakstā nav dotas norādes uz izplatības areālu un biežumu (Fischer 1778: 84-86). J. B. Fišers sniedz arī vairākus latviešu valodā sastopamus stārķa nosaukumus: Starks, Deee, Swehtelis, Swehtsputus (tā!), Schiguris (Fischer 1778: 84).

Arī Johana Melhiora Gotlība Bēzekes (Johann Melchior Gottlieb Beseke; 1746-1802) grāmatā „Beytrag zur Naturgeschichte der Vögel Kurlands..“ iekḷauts gan baltais stārḳis (A. Ciconia. 7), gan melnais stārḳis (A. Nigra. 8). Pie baltā stārķa sniegta informācija, ka tas sastopams bieži, bet pie melnā stārḳa rodama informācija par tā izskatu, kā arī norādīts, ka tas ligzdo šeit, resp. Kurzemē (Beseke 1792: 57).

\section{Stārḳa nosaukumi 17.-19. gs. latviešu valodas vārdnīcās}

Ielūkojoties „Latviešu valodas dialektu atlanta“ leksikas daḷas 36. kartē (LVDA), redzams, ka stārķim ir ļoti daudz nosaukumu, no kuriem lielākā dạ̣a iekḷauta arī kādā no senajām latviešu valodas vārdnīcām.

Pirmajā vācu-latviešu valodas vārdnīcā - Georga Manceḷa „Lettus“ vācu leksēma Storch nav sastopama (Mancelius Lettus 1638). Tai pašā 1638. gadā iznākušajā G. Manceḷa tematiskajā vārdnīcā „Phraseologia Lettica“ sadaḷā „No Puttneems“ iekḷauts vācu Storch ar latviskajiem ekvivalentiem Schugguris / Schubburis / contractè, Schuggurs (Mancelius Phr. 1638: 279).

Kristofora Fīrekera 17. gadsimta latviešu-vācu vārdnīcas pirmajā manuskriptā, kas publicēts 1997. gadā dots plašāks šķirklis Schugure. Stohrke. Germ. Ein Storch. Melna Schuggure / ein schwartzer Storch (Fürecker 1997: 239). Otrajā manuskriptā dota analoga informācija, tikai Stohrke vietā rakstīts Stahrke (Fürecker 1998: 271).

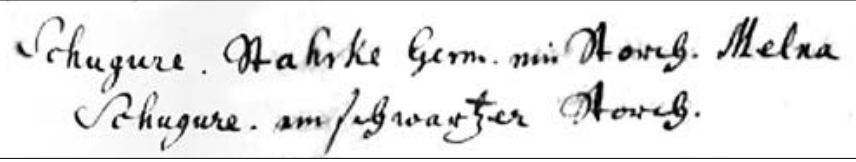

1. attēls. Šķirklis žugure K. Fìrekera vārdnīcas 2. manuskripta 368. 1pp.

(Manuskripts atrodas Latvijas Universitātes Akadēmiskajā bibliotēkā)

Georga Elgera trīsvalodu vārdnīcā „Dictionarium Polono-LatinoLottauicum“ kā poḷu Boćian nafki, latīṇu Ciconia analogs dots Zubburs / Zubburis. Zuggurs. Zugguris / gârnis / kokadzerwa (Elger 1683: 19).

Johana Langija latviešu-vācu vārdnīcā (Langijs 1685: 245) iekḷauta G. Manceḷa „Phraseologia Lettica“ sastopamā informācija (Schugguris 
(Schubburis), contractè Schuggurs, ein Storch), kas papildināta ar Kurzemē zināmām leksēmām (in Churland heift es: Dfähfis, Gandars, Swähtels).

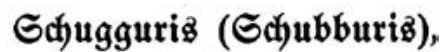 contractè Sđ̆uggurz, ein \\ Stord). in (Eburlandt

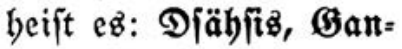 barz̆, Grwähtelz.}

2. attēls. Šķirklis žuguris J. Langija „Latviski-vāciskajā vārdnīcā“, 1685.

(Attēls no E. Bleses sagatavotā izdevuma - Langijs 1685: 245)

17. un 18. gs. mijā sastādītā „Manuale Lettico-Germanicum“ ietverti visi iepriekš minētie J. Langija vārdnīcas dati, kā arī pievienota jauna leksēma Schugdre: Schubburis, Schugguris, Schuggurs, L. J. Schugdre. Storch. in Curl. heist Dsehśis, Gandars, Swehtels. L. (Manuale 128).

Nelielajā 1705. gadā izdotajā vācu-zviedru-poḷu-latviešu vārdnīcā kā vācu Storch ekvivalenti doti Schugguris un Stahrks: Der Storch / Stork / Bocian / Tas Schugguris, Stahrks (Wörter-Büchlein 1705: 43).

Liborija Depkina latviešu-vācu vārdnīcā kā latv. Schugurs atbilsme dots vācu Storch, taču šksirklis papildināts ar sinonīmiem, vārdsavienojumiem un cilmes norādi: Stahrks. Germ: melna Schuggure / meln=Spralis. oder Sprahklis. schwarzer storch. Manc. Schubburs. et Schuggurs. (Depkin IV, 37). Aiz leksēmas Stahrks virs rindām dota atsauce uz Levit[icus] resp. 3. Mozus grāmatu. Stārķa nosaukums tiek pieminēts ne tikai 3. Mozus gr. 11:19, bet arī 5. Mozus gr. 14:18, Jeremijas gr. 8:7, İjaba gr. 39:13 un Psalmos 104:17.

1748. gadā publicētajā Kaspara Elversa vārdnīcā „Liber memorialis Letticus“ iekḷauta virkne latviešu valodas leksēmu: Storch, ftahrks, fwehts putns, fchubburis, fchugguris, dSee, melnfprahklis (Elvers 1748: 242).

Atškirīga informācija sastopama Jakoba Langes vārdnīcā. 1772. gadā izdotajā vācu-latviešu daḷa kā vācu Storch analogs iekḷauts tikai tas fchiguris (Lange 1772: 500). Savukārt latviešu-vācu dalāa ir saistītas leksēmas žūguris un žiguris: Schuhguris, aliis, Schiguris, (*,) ein Storch (Lange 1773: 286). Šai vārdnīcā ieklauta arī leksēma Stahrks tas bet ar skaidrojumu ein Sandart ${ }^{1}$ (Lange 1773, 322).

1 Sandart ir zivs nosaukums. Sal. SANDART, m. sander, zander, zant, zahnt, xant, zehand, sannat, zannaat, der hechtbarsch, perca lucioperca (Deutsches Wörterbuch von Jacob Grimm und Wilhelm Grimm; http://woerterbuchnetz.de/cgi-bin/WBNetz/wbgui_py?sigle=DWB\&mode= Vernetzung\&lemid=GS01608\#XGS01608 
Vēl J. Langes vārdnīcā atrodama arī leksēma Bugure ar skaidrojumu, ka tā dažās vietās sauc stārksi - soll einiger Orten ein Storch heissen (Lange 1773: 67).

Gotharda Frīdriha Stendera „Lettisches Lexikon“ vācu-latviešu daḷā kā vācu Storch analogi iekḷauti ftahrks, fwehts putns, melnfprahklis, kā arī ar norādi uz J. Langes ${ }^{2}$ vārdnīcu ieklạutie fchubburis, fchugguris, fchigguris, dfefe (Stender 1789 II 565-566). Nedaudz atškirīga informācija iekḷauta vārdnīcas 7. pielikumā „Putnu nosaukumi“. Šksirkḷa pirmajai daḷai paliekot nemainīgai, pievienota leksēma fwehtelis ar norādi uz izplatību tāmnieku izloksnēs, kā

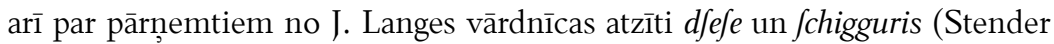
1789 II 756). Šās vārdnīcas latviešu-vācu daḷā iekḷauta lielākā daḷa iepriekšminēto leksēmu: fchigguris, Storch (ar atsauci uz J. Langi) (Stender 1789 I 244), fchubburis, Storch (ar atsauci uz G. Elversu) (Stender 1789 I 252), fchugguris, Storch (ar atsauci uz K. Elversu) (Stender 1789 I 252), ftahrks, Storch (Stender 1789 I 252), fwehts putns, Storch (Stender 1789 I 307), melnfprahklis, Storch (Stender 1789 I 289), dSefe, Storch (ar atsauci uz K. Elversu), Reiher (ar atsauci uz J. Langi) (Stender 1789 I 48). Nedaudz atšksirīga informācija ievietota 7. pielikumā „Putnu nosaukumi“: kohka dfehrwe, Storch (ar atsauci uz J. Langi) (Stender 1789 I 387), dfefe, dfeh/e, Storch (ar atsauci uz J. Langi) (Stender 1789 I 387), melnfprahklis, Storch (Stender 1789 I 388), fandards, Storch (ar atsauci uz J. Langi) (Stender 1789 I 388), fchigguris, Storch (ar atsauci uz J. Langi) (Stender 1789 I 388), fchubburis, fchugguris, Storch (ar atsauci uz J. Langi) (Stender 1789 I 388), ftahrks, Storch (Stender 1789 I 388), fwehtelis, fwehts putns, Storch (ar norādi, ka tiek lietoti tāmnieku izloksnēs) (Stender 1789 I 388).

19. gadsimta vēsturiskajās vārdnīcās atkārtojas visa iepriekšminētā informācija ar nedaudziem papildinājumiem. Jana Kurmina trīsvalodu vārdnīcā kā vienīgais poḷu Bocian analogs dots augšzemnieku dialekta Storks (Kurmin 1858: 10).

Gustava Bražes vācu-latviešu vārdnīcā kā vācu Storch ekvivalenti norādīti ftahrks un fwehtelis (Brasche 1875: 357).

Karla Kristiana Ulmaņa latviešu-vācu vārdnīcā iekḷauts gan ş̧̧irklis ftahrks (Scham. Jtarkus), der Storch, gan šķirklis Jtahrķis, kas iekḷauts kā Liepājas pusē dzirdēts kādas zivs nosaukums (Ulmann 1872: 277). Arī leksēmām fchigurs, chihgurs dotas divas nozīmes, norādot, ka nozīme 'ein Storch' sastopama Augšzemē (Ulmann 1872: 240). Daudznozīmes šķirkḷ fos fchuburs un fchugurs

2 Priekšvārdā G. F. Stenders norāda: „Nur diejenigen Wörter verantworte ich nicht, wo E. oder L. dabey stehet. Diese sind auf Autorität des Elverschen lettischen Wörterbuchs und des Langischen lettischdeutschen Lexikons hingesetzt, und müssen mit einer behutsamen Prüfung gebraucht werden." (Stender 1789, [b. lpp.]) Pārlūkojot ar L. apzīmētos vārdus, škiet, ka tie ir pārņemti gan no J. Langija manuskripta, gan no J. Langes vārdnīcas. 
dotas norādes uz citiem šķirklịem, kur noslēdzošais ir fchigurs (Ulmann 1872: 240, 241). Šai vārdnīcā iekḷauta arī leksēma fwehtelis, der Storch ar norādi uz izplatību Rietumkurzemē (Ulmann 1872: 289). Kā stārḳa apzīmējums minēts arī gandrs, der Storch ar norādi uz lietuviešu gandras (Ulmann 1872: 71). Leksēmām dfehfe, dfehfis, dfehfnis, der Storch pievienota areālā norāde, ka tā sastopama pie „Wentineeken”, kā arī iespējamā sugas norāde, ka šīs leksēmas lielākoties apzīmē melno stārḳi (der schwarze Storch) vai gārni (der Reiher) (Ulmann 1782: 56). K. K. Ulmaņa latviešu-vācu vārdnīcā sastopama arī no L. Depkina vārdnīcas pārņemtā leksēma d fehftrs, der Storch, kurai pievienots paskaidrojums, ka tā nav zināma (Nicht bekannt) (Ulmann 1872: 56).

Gustava Bražes un K. K. Ulmaņa vācu-latviešu vārdnīcas dạ̣ā vācu Storch dotas četras atbilsmes: ftahrks, fwehtelis, gandrs, klabata (Brasche, Ulmann 1880: 676).

Trīsvalodu krievu-latviešu-vācu vārdn̄icā krievu aŭcmb un vācu Storch atbilsmes ir swehtelis, starks un gandris (Waldemars 1872: 2).

\section{Stārḳa nosaukumi K. Mīlenbaha un J. Endzelīna „Latviešu valodas vārdnīcā" un tās papildinājumos}

Kārḷa Mīlenbaha un Jāņa Endzelīna „Latviešu valodas vārdnīcā“ un tās papildinājumos iekḷauta iepriekšêjās vārdnīcās publicētā informācija, kas papildināta ar precīzām areālajām norādēm, kā arī no publicētajiem avotiem iekḷauti atsevišķ līdz tam leksikogrāfiskajos avotos nefiksēti nosaukumi

\section{àzis}

K. Mīlenbaha un J. Endzelīna „Latviešu valodas vārdnīcā“ metaforiskais stārksa nosaukums dieva āzis iekḷauts no mēnešraksta „Austrums“ pēc Apsīšu Jēkaba informācijas (ME I 246 sub voce âzis). Arī nosaukumu dìevâzītis, kas ir mērkaziņas apzīmējums, Apsī̌̌u Jēkabs no Lizuma attiecina uz stārḳi (ME I 484). Starp abiem putniem nekāda līdzība nav saskatāma, grūti saskatīt arī līdzību ar āzi, kas varētu būt šā nosaukuma pārnesuma pamatā. Iespējams, nosaukums ir okazionāls lietojums. Tas nav minēts arī „Latviešu valodas dialektu atlanta“ leksikas dạ̣ā (LVDA).

\section{bugure}

Nosaukums bugure 'der Storch' ieklauts K. Mīlenbaha un J. Endzelīna „Latviešu valodas vārdnīcā“ (ME I 345) no J. Langes vārdnīcas, kur šim apzīmējumam pievienots komentārs, ka tā dažās vietās sauc stārkịi (Lange 1773: 67). Nosaukums ir pieminēts, taču nav kartografēts LVDA (98).

3 Šì informācija norādīta pie konkrētās leksēmas analīzes. 


\section{cikoniņš}

Nosaukums cikuoniņš ‘der Storch’ iekḷauts K. Mīlenbaha un J. Endzelīna vārdnīcas papildinājumos no mācītāja lubānieša Mārtiņa Celmiña vārdu krājuma (EH I 269). Kā norāda J. Endzelīns, vārds saistīts ar latīnisko stārķa apzīmējumu cicōnia. Nosaukums nav pieminēts LVDA.

\section{dzērve}

Vārdkopnosaukumu kuoka dzērve 'der Storch' J. Endzelīns iekłạ̄ivis pēc Gustava Bergmaņa manuskripta resp. K. K. Ulmaņa vārdnīcas (ME I 548). Jāpiebilst, ka vārdkopnosaukuma kuoka dzērve pirmā nozīme ir cits putns - zivju ērglis. K. Mīlenbaha un J. Endzelīna vārdnīcas papildinājumos (EH I 357) vārdkopnosaukums kuoka dzērve iekḷauts no E. Glika tulkotās Bībeles İjaba grāmatas 16. rindu. Mūsdienu tulkojumā 16. rindā nav minēts stārķa nosaukums, leksēma stārkìis resp. stārķa māte analogā kontekstā sastopama 13. rindā.

Nosaukums radies uz putnu ārējās līdzības pamata, vārdkopnosaukuma pirmajam komponentam norādot uz stārḳu ligzdošanu kokos. Latviešu dzērve, lietuviešu gervé, prūšs gerwe pamatā varētu būt putna balss skaņu atdarinājums (Karulis 1992: 249).

Nosaukums ir pieminēts, taču nav kartografēts LVDA (98).

\section{dzēse, dzēze, dzēstrs}

K. Mīlenbaha un J. Endzelīna „Latviešu valodas vārdnīcā" leksēma $d z \bar{e} s e$ iekḷauta bez vietas norādes, $d z \bar{e} s i s$ - no Kurs̄išiem, $d z \bar{e} s n i s$ - bez vietas norādes, bet kā pirmā nozīme dota vai nu melnais stārksis (pēc RLB Rakstu krājuma), vai pēc Magazīnās ieklautās informācijas pie „,ventiniekiem“ tas ir vispārināts stārķa apzīmējums (ME I 548). Tāpat šeit atrodama informācija, ka G. Manceḷa, G. Elversa un J. Langes vārdnīcās iekḷautā forma dzese ir kḷūdaina, jābūt $d z \bar{e} s e$ (ME I 548). Variants dzēze iekḷauts K. Mīlenbaha un J. Endzelīna „Latviešu valodas vārdnīcā" no RLB Konversācijas vārdnīcas ar nozīmi melnais stārḳis un J. Endzelīna piezīmi, ka varētu būt kḷūdains pieraksts no dzēse (EH I 349).

Ar nosaukumu dzēse saistīts arī cits stārķa apzīmējums $d z \bar{e} s t r s$, kas K. Mīlenbaha un J. Endzelīna „Latviešu valodas vārdnīcā“ iekḷauts no L. Depkina vārdnīcas un RLB Rakstu krājuma (ME I 349).

Vārda $d z \bar{e} s e(<* d z \bar{e} r s e)$ pamatā putna balss skaņu atdarinājums (ME I 548, Karulis 1992: 249-250).

LVDA ir pieminēts nosaukums $d z \bar{e} s i s$ no J. Langija vārdnīcas, taču tas nav kartografēts (LVDA 98).

\section{gandrs}

K. Mīlenbaha un J. Endzelīna „Latviešu valodas vārdnīcā“ sastopams arī tradicionāls melnā stārķa apzīmējums, kas attiecināts arī uz jebkuru 
stārkịi - gañdrs; tas fiksēts Trikātā, Rucavā, K. Līniņa vākumos (no Nīkrāces), Nìgrandē un Kalētos, un gan̂dris, kas pierakstīts Lielezerē (ME I 599). J. Endzelīns norāda, ka acīmredzot šis nosaukums zināms tikai Lietuvas pierobežā un aizgūts no liet. gañdras, kas savukārt līdz ar senprūšu gandams radies no gérmān̨u valodām (ME I 599). „Baltu valodu atlanta“ prospektā (BVA 99) norādīts, ka lietuviešu gañdras 'stārkịis' un latviešu gandrs 'stārķis' veido plašu kompaktu areālu, apstiprinot J. Endzelīna hipotēzi par to, ka latviešu valodā šis vārds varētu būt aizgūts no lietuviešu valodas pēc tā izplatības areāla. Tiek precizēta lietuviešu gañdras cilme. Agrāk tas tika uzskatīts par aizguvumu no Austrumprūsijas vācu valodas izloksnēm (ME I 599; Fraenkel I 133; Smoczyński 2007: 156). Pašlaik valda uzskats, ka lie. gañdras varētu būt arī ar piedēkli atvasināts onomatopoētisks baltu cilmes vārds tāpat kā prūšu *gandarus (<* gandras) (Toporov 1979: 152; Mažiulis 1988: 323; Sabaliauskas 1990: 261).

LVDA leksēma gandris vai gandrs fiksēta Dienvidrietumkurzemē Lietuvas pierobežā (LVDA 96; 36. karte). Atsevišksi šîs leksēmas pieminējumi citās Latvijas vietās nav kartogarfēti (LVDA 98).

\section{garķis, gārḳis}

Tikai K. Mīlenbaha un J. Endzelīna „Latviešu valodas vārdnīcā“ no RLB Rakstu krājuma iekḷauts baltā stārķa nosaukums garķis, kas varētu būt radies nosaukumu garnis un starķis kontaminācijas rezultātā (ME I 603). Variants gārķis minēts no Burtniekiem pēc K. K. Ulmaņa vārdnīcas (ME I 618).

LVDA fiksēts nosaukums gārkisis no Burtniekiem pēc K. Mīlenbaha un J. Endzelīna „Latviešu valodas vārdnīcas“, taču tas nav kartografēts (LVDA 98).

\section{garnis, gārnis}

K. Mīlenbaha un J. Endzelīna „Latviešu valodas vārdnīcā“ uz stārḳi attiecināts arī gārņa apzīmējums: gar̂nis sastopams Grundzālē un saistīts ar liet. garnỹs (ME I 603), bet gārnis kā stārķa apzīmējums - Smiltenē (ME I 618).

Vārda garnỹs etimolog̣ija joprojām ir diskutējama. Agrāk šo nosaukumu saistīja ar liet. gérvè, pr. gerwe (Fraenkel I 137-138; Pokorny 1969: 383 utt.). Taču tagad daži etimologi šo hipotēzi atmet, jo nav iespējams izskaidrot dažas fonētiskās pārmaiņas (Smoczyński 2007: 160). Domājams, ka liet. garnỹs ir

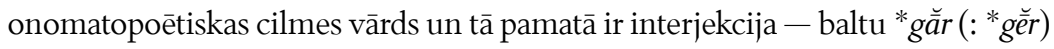
(Mažiulis 1988: 335). Pēc citu valodnieku domām (Urbutis 1981: 18, 1. par.), sakne gar- saistāma ar *ger-, sal. darbības vārdu gérti 'dzert', kas no senāka 'rīt'.

K. Mīlenbaha un J. Endzelīna „Latviešu valodas vārdnīcā“ sastopamā informācija iekḷauta arī LVDA (98), nosaukums nav kartografēts. 


\section{kārķis}

K. Mīlenbaha un J. Endzelīna „Latviešu valodas vārdnīcā“ ieklạts nosaukums kãrkịis 'der Storch' no Vilces, kas, iespējams, radies kārnis 'gārnis' un stārķis kontaminācijas rezultātā (ME II 196).

K. Mīlenbaha un J. Endzelīna „Latviešu valodas vārdnīcā“ sastopamā informācija iekḷauta arī LVDA (98), nosaukums nav kartografēts.

\section{klabata}

Metaforiskais nosaukums klabata 'der weisse Storch' K. Mīlenbaha un J. Endzelīna „Latviešu valodas vārdnīcā“ ieklạuts no RLB Rakstu krājuma (ME II 207).

LVDA nosaukums klabata minēts no dažām atstatām Latvijas vietām, piemēram, Jeriem un Ezeres; nav kartografēts (LVDA 98).

\section{krulla}

Tikai K. Mīlenbaha un J. Endzelīna „Latviešu valodas vārdnīcas“ papildinājumos ieklauts nosaukums krulla, kas Vidzemes sēliskajās izloksnēs apzīmē gan dzērvi (Lubānā), gan stārḳi (Meirānos) (EH I 659).

LVDA nosaukums krulla iekḷauts no K. Mīlenbaha un J. Endzelīna „Latviešu valodas vārdnīcas“, nav kartografēts (LVDA 98).

\section{melnsprāklis}

Baltā stārḳa nosaukums mệ̃nsprãklis ieklạts K. Mīlenbaha un J. Endzelīna „Latviešu valodas vārdnīcā“ no RLB Rakstu krājuma (ME II 599).

Nosaukums iekḷauts LVDA kā rakstu avotos fiksētais, nav kartografēts (LVDA 98).

\section{parkšksis}

K. Mīlenbaha un J. Endzelīna „Latviešu valodas vārdnīcā“ iekḷauts arī nosaukums parkšksis ar sarunvalodisko tulkojumu Klapperstorch no Jēkaba Dravnieka materiāliem (ME III 91).

LVDA nav minēts.

\section{stark-, stārk-, stork-}

K. Mīlenbaha un J. Endzelīna „Latviešu valodas vārdnīcā“" un tās papildinājumos iekḷauti vairāki šksirklị ar saknēm stark-, stārk- un stork-. Šksirklī stàrka dots variants stàrka no Praulienas bez konkrētas nozīmes, kā arī ar vācisko ekvivalentu ‘der Storch' nosaukums star̃ka no Raunas (Pētera Šmita materiāli) un Taurenes, variants ar krītošo intonāciju stàrka no Liezēres, Suntažiem, Lizuma, Saikavas, Sausnējas (Jāṇa Kauliņa materiāli), variants starka no Lubānas, starks - no Lielsalacas un Varakḷāniem, star̃ ks - no Valmieras, 
leksēma starks ieklauta arī Magazinnās ${ }^{4}$ bez vietas norādes un Pētera Šmita pasaku izdevumā no Dzirciema. Variants staṛ̂̂is sastopams Alūksnē (no RLB Rakstu krājuma), Dzelzavā, Gulbenē, variants staŗ̣̃is - Drustos (J. Cīruḷa vākumi), Zaubē, Āraišos, Skujenē, Rūjienā, bet variants stàrķis - Suntažos un Meirānos (ME III 1045). K. Mīlenbaha un J. Endzelīna „Latviešu valodas vārdnīcas“ papildinājumos variants staŗ̂̉is iekḷauts vēl arī no Vecpiebalgas, Straupes un Vecsalacas, bet intonatīvais variants staṛ̂̂is - no Alsviķiem, Jaunlaicenes un Rankas (EH II 571).

Šksirklī stārka arī iekḷauti vairāki varianti. Sieviešu dzimtes variants stārka fiksēts Pḷavin̄ās no krājuma „Etnogrāfiskas ziņas par latviešiem“ un „Filologu biedrības rakstiem“. Variants stãrks pierakstīts Cesvainē, Džūkstē un Bērzmuižā, bet stārks pārņemts no K. Ulmaņa vārdnīcas un fiksēts Purmsātos. Variants stãrķis minēts no Lielsalacas, Kandavas un Dzirciema, stārķis - no Pḷaviņām (pēc Filologu biedrības rakstiem). Šḳirkḷa ilustratīvajā materiālā minēts vēl stārks no krājuma „Etnogrāfiskas ziņas par latviešiem“ un Glika Bībeles Psalmiem 104:17. Latvju dainās sastopams variants stārka (ME III 1051). K. Mīlenbaha un J. Endzelīna „Latviešu valodas vārdnīcas“ papildinājumos leksēma stārka minēta no Pēterupes muižas, kā arī no Valmieras (no A. Bīlenšteina ierakstītiem vārdiem K. Ulmaņa vārdnīcas eksemplārā) (EH II 573). Varianta stārks izplatības areāls papildināts ar Bēni, Praviņiem un Džūksti, kā arī tas minēts Latvju dainās (EH II 573). Latvju dainās sastopams arī variants stārķis (EH II 573).

Šksirklì storķis 'der Storch' minēts, ka šī leksēma pierakstīta Dundagā, Vandzenē, Nurmuižā un Lubezerē (ME III 1080).

K. Mīlenbaha un J. Endzelīna „Latviešu valodas vārdnīcas“ papildinājumos ietverti arī vairāki stārķu mazuḷu un jaunu stārḳu apzīmējumi (ein Storchjunges): variants stãrcẹens ieklạauts no Džūkstes (EH II 573), variants star̃e êns - no Vecpiebalgas (EH II 571), starķệns - no Jāṇa Jaunsudrabiņa darbiem (EH II 571), starkulẹnn - no Vestienas (pēc „Filologu biedrības rakstiem“) (EH II 571).

Pēc „Baltu valodas atlanta“ prospektā iekḷautās informācijas (BVA 99) latviešu stārķis un lietuviešu star̃kas, kā arī to varianti parasti tiek uzskatīit par g̊ermānismiem - aizguvumiem no vlv. stark (ME III 1045; sal. vlv. stork SL IV 414; Fraenkel II 897; Karulis 1992: 286; Smoczyński 2007: 597). Tomēr Vincs Urbutis, balstoties uz vārda plašo izplatību lietuviešu valodas izloksnēs, šo uzskatu apšauba, norādot, ka vārds visdrīzāk ienācis caur latviešu valodu, nevis tieši no vācu valodas (Urbutis 2002: 18).

4 Vārdnīcā norādītais materiāls ņemts no Jelgavas skolotāia Pētera Zēvalda Birzgalē (Linden) pierakstīto vārdu saraksta, kas iekḷauts Magazīnu 13. laidiena 2. burtnīcā. 
Pēc LVDA datiem nosaukums stārķis izloksnēs sastopams samērā plaši, taču nekur tas neveido zīmīgu areālu. Vairākiem novadiem raksturīgāki ir šī nosaukuma citi fonētiskie vai morfolog̣iskie varianti. Zemgalē un Vidzemē samērā plaši izplatīti starḳis un starks, Ziemeḷkurzemē - storķis (LVDA 96-98).

\section{stāks}

K. Mīlenbaha un J. Endzelīna „Latviešu valodas vārdnīcas“ papildinājumos no Straupes ievietots šķirklis stãks ar $r$ zudumu (EH II 573).

No šejienes tas iekḷauts LVDA, nav kartografēts (LVDA 98).

\section{stērga}

K. Mīlenbaha un J. Endzelīna „Latviešu valodas vārdnīcā“ sastopams arī stārķa nosaukums stệrga, kas tur iekḷauts no Grendzes pēc A. Becenberǵera materiāliem (ME III 1063).

LVDA šis nosaukums nav minēts.

\section{stikāns}

K. Mīlenbaha un J. Endzelīna „Latviešu valodas vārdnīcas“ papildinājumos minēta leksēmas stikāns nozīme 'stārksis' no Kacēniem (EH II 578). Pamatsējumos fiksēts cita putna nosaukums ar aprakstošu skaidrojumu: 'ein Wasservogel mit langen beinen und langem Schnabel (ūdensputns ar garām kājām un garu knābi)' (ME IV 1066).

No minētajām vietām tas minēts arī LVDA, nav kartografēts (LVDA 98).

\section{svēt-}

K. Mīlenbaha un J. Endzelīna „Latviešu valodas vārdnīcā“ un tās papildinājumos iekḷauti vairāki ş̧̧irkḷi ar sakni svēt-. Variants svệtainis 'der Storch' minēts no Brizules, Lielezeres, Kursīšiem, Rengğes un Rūjienas (ME III 1154). Variants svêtelis 'der Storch (ciconia alba)' fiksēts Leitīšniekos, Aizvīksos, Apriķos, Lažā, Nīcā, Skrundā un Vērgalē, variants svètelis pārņemts no G. F. Stendera vārdnīcas ar norādi, ka sastopams tāmnieku izloksnēs, un K. K. Ulmaņa vārdnīcas ar norādi, ka sastopams Rietumkurzemē. Tāpat variants svētelis reǵistrēts Alsviķ̧os. K. Mīlenbaha un J. Endzelīna „Latviešu valodas vārdnīcas“" papildinājumos leksēma svêtelis minēta arī no Vecpiebalgas un Snēpeles, bet svêtelis - no Nīcas (EH II 617).

Variants svêtêlis minēts no Dunikas, bet svệtals (no *svẹ̄tuls?) - no Sarkanmuižas. Šai šķirklī ieklauts arī deminutīvs svệtẹlẹnns (ME III 1155). K. Mīlenbaha un J. Endzelīna „Latviešu valodas vārdnīcas“ papildinājumos škirklī svệtẹlệns iekḷauts paskaidrojums, ka svệtẹlệns nav nievājošas nokrāsas deminutīvs no svêtelis; tas ir stārķu mazulis resp. jauns stārķis (EH II 617). 
Šķirklī svệtputns 'der Storch’ šis variants norādīts no Rudbāržiem, Alsungas, Jūrkalnes un Kuldīgas, variants suệtsputns iekḷauts no J. B. Fišera pētījuma (ME III 1156).

Šķirklī svẹttulis tikai trešā nozīme ir stārḳa nosaukums 'der Storch', kas pierakstīts Ērglıos, Zaḷeniekos un Krustpilī (ME III 1156).

K. Mīlenbaha un J. Endzelīna „Latviešu valodas vārdnīcas“ papildinājumos šksirklim svètenis pievienota otrā nozīme 'der Storch', kas fiksēta Bilskā (EH II 617).

Arī škirklī sventelis ir minēta otrā nozīme 'der Storch' variantam sveñtelis no Valtaikiem (EH II 615).

Pēc „Baltu valodu atlanta“ prospektā (BVA 101) minētā, nosaukumi ar komponentu svệt-, iespējams, atvasināti no adjektīva svệts, taču iespējams, ka šim vārdam ir senāka cilme un tas saistāms ar *svēts 'gaišs, balts' (Karulis 1992: 336).

Pēc LVDA datiem kompaktā areālā Kurzemē (izņemot Ziemeḷkurzemi) lieto nosaukumu svètelis, kas pazīstams arī Vidzemē un Zemgalē. Kurzemes vidienē nelielu kompaktu areālu veido arī nosaukums svệtputns (arī svệts putns). Citi varianti ar sakni svēt- sporādiski reg̣istrēti Kurzemē (LVDA 96-98; 36. karte).

\section{štarks}

K. Mīlenbaha un J. Endzelīna „Latviešu valodas vārdnīcas“ pamatsējumos minēts šķirklis štarks no Zasas (ME IV 102).

LVDA nosaukumi ar sakni štark- fiksēti Latgales rietumu dạ̄ā un Augšzemē (LVDA 98; 36. karte).

\section{tarks, tā(r)ks}

Šksirklī tar̃ks 'starks, der Storch' fiksēts variants tar̃̂s no Baldones un Zālītes, variants tâ̂ks - no Pāles, Lielvārdes (pēc K. K. Ulmaņa vārdnīcas) un Lēdmanes (ME IV 132). Šḳirklī tãks 'der Storch' šis variants minēts no Lustes muižas (ME IV 144). Nosaukums tārciņš ‘der Storch' ieklauts bez vietas norādes (ME IV 149).

Nosaukumi tarks, $t \bar{a}(r) k s$ LVDA reğistrēti atsevišķās vietās Vidzemē un Zemgalē (LVDA 98; 36. karte).

\section{viestur-}

K. Mīlenbaha un J. Endzelīna „Latviešu valodas vārdnīcā“ iekḷauti škirkḷıi vìesturis un viesturs, kuru otrā nozīme 'der Storch' minēta no Nīcas pēc J. Janševska darbiem (ME IV 671).

LVDA pieminēts no rakstītiem avotiem, nav kartografēts (LVDA 98). 


\section{zubur-, žubur-}

Šķirklī zubur(i)s ‘der Storch’ atrodama norāde, ka nosaukums pārņemts no Elgera vārdnīcas un, ka acīmredzot tam jābūt ar $\check{z}$ (ME IV 749). Arī škirklī žuburis 'der Storch' ir redzama tikai no citām vārdnīcām ieklautā informācija: žuburis - no G. Manceḷa vārdnīcas „Lettus“ un K. Elversa vārdnīcas, žuburs - no K. K. Ulmaņa vārdnīcas (ME IV 828). K. Mīlenbaha un J. Endzelīna „Latviešu valodas vārdnīcas“ papildinājumos ieklạauta leksēma žubure no Barkavas (EH II 821).

LVDA nosaukums fiksēts tikai atsevišķās vietās Latgalē (LVDA 98).

\section{žigur-, žīgur-}

Šḳirkḷos žigurs un žl̆guris atrodama norāde vismaz uz diviem pilnīgi atšķirīgiem putniem — zvirbuli un stārķi. Variants žigurs 'ein Storch' pārņemts no K. K. Ulmaņa vārdnīcas ar izplatības areālu Augšzemē, variants žiguris 'ein Storch' - no J. Langes vārdnīcas (šis variants minēts arī no J. L. Fišera darba) (ME IV 809). Šksirklī žlouris variants ž̄̄gurs minēts no K. K. Ulmaņa vārdnīcas ar vietas norādi Augšzemē. Šeit kā ilustratīvais materiāls minēti arī atseviški tautasdziesmu varianti, kuros aprakstītais putns nav skaidri nosakāms (ME IV 813).

LVDA nav ieklauts.

\section{žugure}

Variants žugure fiksēts Lubānā (pēc izdevuma Etnogrāfiskas ziņas par latviešiem) un Latgalē (Inflantijā), konkrēti minot Barkavu, Preilus, Varakḷānus un Viḷānus, variants žuguris pārṇemts no G. Manceḷa vārdnīcas „Lettus“ un G. Elversa vārdnīcas, variants žugurs pārņemts no K. K. Ulmaņa vārdnīcas. Ilustratīvajā materiālā minēti A. Austriņa darbi un pasakas (ME IV 829).

Pēc „Baltu valodu atlanta“ prospektā norādītās informācijas (BVA 102) V. Urbutis (Urbutis 1981: 34) konstatējis, ka vārds žugure (sal. arī žūguris, zugur(i)s un zubur(i)s) ir aizgūts no lietuviešu valodas. Konstantina Sirvida pirmajā vārdnīcā fiksēta vārda žugara nozīme 'stārkisis': Ç̉apła / Ardea. Garnis / żugara. Mūsdienu lietuviešu izloksnēs šo vārdu lieto kā pejoratīvu personas apzīmējumu. Tas ir saliktenis no žuvìs 'zivs' un gérti 'dzert'.

LVDA leksēmas žugare un žugure veido samērā izteiktu areālu Latgalē (LVDA 98).

Latviešu valodas vārdnīcās nav sastopami atsevišķi 20. gs. otrajā pusē pierakstītie un LVDA ieklauautie stārķa nosaukumi. Pirmkārt, tie ir no slāvu valodām aizgūtie lielākoties Latgalē fiksētie nosaukumi: àists ( $<$ kr. aist, bkr. aist), bacàns, arī bacijans, bacjans, bacjons, bačans, bocjans ( $<$ baltkrievu dial. 
bacjan, bocjan, poḷu bocian), bočaks, kalests, arī kalusts (< kr. apv. kalist), klikuns ( $<$ kr. dial. klikun), polakss (radies ar vārda nozīmes pārnesumu, sal. kr. poljak 'polis'), žùrējs. Otrkārt, g̊ermānismi: klaperštoks. Treškārt, no personvārdiem darinātie stārķa nosaukumi: añdrējs.

\section{Secinājumi}

Latviešu valodas senajās vārdnīcās iekḷautie stārḳa nosaukumi norāda uz apzīmējumu daudzveidību. 17.-19. gs. latviešu valodas vārdnīcās iekḷauti 15 stārķa nosaukumi ar fonētiskajiem un morfolog̣iskajiem variantiem (sk. tabulu). Vairāki no šiem nosaukumiem ir citu putnu - dzērves un gārņa nosaukumi. Pēc mūsdienu klasifikācijas Latvijā sastopamā pelēkā dzērve (Grus grus) ir dzērvju dzimtas sugas putns, tā ir lielāka par stārḳi, ar garām melnām kājām un garu kaklu, apspalvojums gaišpelēks, galvas un kakla sānos balta josla, piere, rīkle, kakla priekšpuse un spārnu gali melni. Pelēkā dzērve ir gājputns (LD II 30). Daudz plašāka ir gārņu dzimta, kurā ietilpst vidēji lieli līdz lieli bridējputni ar garām kāiām, garu kaklu un knābi, kas dzīvo mitros, sekliem ūdeņiem bagātos biotopos (LD II 94). Dzēse ir zivju gārņa sinonīms, Nevar noliegt, ka visiem šiem putniem ir daudz kopīgu ārējo pazīmju — garas kājas, garš kakls un knābis.

Mūsdienu kopvalodā izplatītais nosaukums stārķis (aizguvums no vlv. stork) ar tā fonētiskajiem un morfolog̣iskajiem variantiem leksikogrāfiskajos avotos parādās 17. gadsimta otrajā pusē - K. Fīrekera vārdnīcā, kas publicēta tikai 20. gadsimta beigās pēc diviem atš̌kirīgiem norakstiem, no kuriem vienā parādās variants stohrks, bet otrā - stahrks. 17. gadsimta beigās tas līdzās citiem nosaukumiem parādās E. Glika Bībeles tulkojumos. Pēc „Seno tekstu korpusa“ datiem (senie.korpuss.lv) Bībelē fiksēts variants stārks. Iespējams, tieši no E. Glika Bībeles teksta tulkojuma nosaukums stārķis resp. stārks ieviesies latviešu valodā. Ka šis latviešu valodā ir jauninājums, rāda paralēli lietotie vācu 'der Storch' citi nosaukumi, piemēram, kohka dfehrwe (Ījaba grāmata 39:16), kas varētu norādīt, ka vēl nebija ieviesies viens stārķa nosaukums un tulkotāi izmantoja sev zināmāko variantu.

Visnoturīgākie 17.-19. gadsimta latviešu vēsturiskajās vārdnīcās ir stārķa nosaukumi žubure un žugure ar fonētiskajiem un morfoloǵiskajiem variantiem, kas 20. gadsimta otrajā pusē sastopami nelielā areālā Latgalē.

Nosaukumu daudzveidība bez skaidri izteiktiem izplatības areāliem varētu norādīt, ka virkne nosaukumu ir samērā jauni - attiecināmi uz 17.-18. gadsimtu. Ar šo laiku tiek skaidri datēta arī stārķa (pārsvarā melnā stārķa) uzturēšanās tagadējā Latvijas teritorijā. 
Tabula

Stārḳa nosaukumu secība 17.-19. gs. latviešu leksikogrāfiskajos avotos

\begin{tabular}{|c|c|}
\hline bugure & Lange 1773 \\
\hline $\begin{array}{l}d z e z-, d z \bar{e} z- \\
d z e s-, d z \bar{e} s-\end{array}$ & $\begin{array}{l}\text { Langijs 1685, Manuale, Elvers 1748, Stender } 1789 \text { I, } \\
\text { Stender } 1789 \text { II, Ulmann } 1872\end{array}$ \\
\hline$d z \bar{e} s t r s$ & Ulmann 1872 \\
\hline gandr- & $\begin{array}{l}\text { Langijs 1685, Manuale, Ulmann 1872, Brasche, Ulmann 1880, } \\
\text { Waldemars } 1872\end{array}$ \\
\hline gārnis & Elger 1683 \\
\hline klabata & Brasche, Ulmann 1880 \\
\hline kokadzērva & Elger 1683 \\
\hline melnsprāklis & Depkin IV, Elvers 1748, Stender 1789 I, Stender 1789 II \\
\hline sandars & Langijs 1685 \\
\hline $\begin{array}{l}\text { stārk-, stark-, } \\
\text { stork- }\end{array}$ & $\begin{array}{l}\text { Fürecker 1997, Fürecker 1998, Wörter-Büchlein 1705, } \\
\text { Depkin IV, Elvers 1748, Lange 1773, Stender } 1789 \text { I, } \\
\text { Stender 1789 II, Kurmin 1858, Brasche 1875, Ulmann 1872, } \\
\text { Brasche, Ulmann 1880, Waldemars } 1872\end{array}$ \\
\hline svētel-, svēts putns & $\begin{array}{l}\text { Langijs 1685, Manuale, Elvers 1748, Stender } 1789 \text { I, } \\
\text { Stender } 1789 \text { II, Brasche 1875, Ulmann 1872, Brasche, } \\
\text { Ulmann 1880, Waldemars } 1872\end{array}$ \\
\hline žigur-, žīgur- & $\begin{array}{l}\text { Lange 1772, Lange 1773, Stender } 1789 \text { I, Stender } 1789 \text { II, } \\
\text { Ulmann } 1872\end{array}$ \\
\hline žubur-, zubur- & $\begin{array}{l}\text { Mancelius Phr. 1638, Elger 1683, Langijs 1685, Manuale, } \\
\text { Depkin IV, Elvers 1748, Stender } 1789 \text { I, Stender } 1789 \text { II, } \\
\text { Ulmann } 1872\end{array}$ \\
\hline žugdre & Manuale \\
\hline žugur-, zugur- & $\begin{array}{l}\text { Mancelius Phr. 1638, Fürecker 1997, Elger 1683, Langijs 1685, } \\
\text { Manuale, Wörter-Büchlein 1705, Depkin IV, Elvers 1748, } \\
\text { Lange 1773, Stender } 1789 \text { I, Stender } 1789 \text { II, Ulmann } 1872\end{array}$ \\
\hline
\end{tabular}

Vārdnīcās neietvertie lielākoties Latgalē fiksētie nosaukumi norāda, ka vārdnīcu autori pilnībā nepārzināja šai teritorijā sastopamos vārdus, kaut gan jau G. Mancel̦a „Phraseologia Lettica“ ieklautie žubure un žugure izplatīti tieši Latgalē. Iespējams, šo nosaukumu izplatības areāls 17. gadsimtā bija daudz plašāks. Nosaukumi ar žigur- un žl̆gur- varētu būt J. Langes nepareizi interpretēta forma no žugur-, jo nevienā avotā nav izdevies konstatēt, ka par žīguru sauktu stārḳi. Tas ir zvirbuḷa nosaukums, kas samērā plašā areālā izplatīts Vidzemes ziemeḷos un ziemeḷaustrumos, kā arī Latgales ziemeļos.

K. Mīlenbaha un J. Endzelīna „Latviešu valodas vārdnīcā“ un tās papildinājumos ieklauti gandrīz visi 17.-19. vārdnīcās minētie stārķa apzīmējumi, 
atsevišķos škirkḷ os izdalot vairākus fonētiskos un morfoloǵiskos variantus. Tāpat reğistrēti vairāki okazionāli vai reti sastopami nosaukumi, piemēram, cikoniņš, krulla, parkššis, stērga, stikāns, viesturs.

Stārķa nosaukumu daudzveidība norāda uz putna (īpaši baltā stārķa) samērā nesenu ligzdošanu Latvijas teritorijā, kā arī uz tā nosaukumu rašanos un motivējošām pazīmēm: nosaukuma pielīdzināšana jau zināmu putnu nosaukumiem (dzērve, gārnis, $d z \bar{e} s e$ ), raksturīgu pazīmju iekḷaušana nosaukumā (klabata, melnsprāklis, parkšksis), saistība ar mitolog̣iskiem priekšstatiem (svètelis, svēts putns).

\section{Avoti un literatūra}

Beseke, Johann Melchior Gottlieb. 1792.

Brasche, Gustav. 1875.

Brasche, Gustav, Ulmann, Carl Christian. 1880.

$\mathrm{BVA}=$

Depkin IV =

$\mathrm{EH}=$

Elger, Georgius. 1683.

Elvers, Caspar. 1748.

Fischer, Jacob Benjamin. 1778.
Beytrag zur Naturgeschichte der Vögel Kurlands mit gemalten Kupfern, Nebst einem Anhange über die Augenkapseln der Vögel von Johann Melchior Gottlieb Beseke. Mitau und Leipzig: gedruckt bey J. F. Steffenhagen.

Allererfte Anleitung zum Gebrauch der lettifchen Sprache für deutfche von G. Brafche. I. Abteilung: Grammatik, II. Abteilung: Lettifch-Deut/ches Lexikon, III. Abteilung: Deut/ch-Lettifches Lexikon, IV. Abteilung: Gefspräche. Libau: Verlag von G. L. Zimmermann.

Lettifches Wörterbuch von Ulmann und Brafche. Zweiter Theil. Deutfch-lettifches Wörterbuch mit Zugrundelegung des von Bifchof Dr. Carl Chriftian Ulmann zurükgelafJenen Manu$\int$ criptes bearbeitet von Guftav Brafche, Paftor emer. Riga u. Leipzig: Verlag von H. Brutzer \& Co.

Baltu valodu atlants. Prospekts. Rīga: LU latviešu valodas institūts, Vilnius: Lietuvių kalbos institutas, 2009.

Liborius Depkin. Lettisches Wörterbuch 4. The original manuscript transcribed and annotated by Trevor G. Fennell. Rìga: Latvijas Akadēmiskā bibliotēka, 2008 [1704].

Endzelīns, Jānis, Hauzenberga, Edīte. Papildinājumi un labojumi K. Mülenbacha „Latviešu valodas vārdnīcai“" Rīga: Kultūras fonds, 1934-1938; 2, Rīga: Grāmatu apgāds, 1946.

Dictionarivm Polono-Latino-Lottauicum. Opus posthumum. R.P. Georgii Elger ... Vilnae.

Liber memorialis Letticus, Oder Lettisches Wörterbuch, Sowohl Für die Einheimischen als Fremden / Anstat eines Lexici eingerichtet / Und allen denen zum Besten die in diesem Lande in Kirchen und Schulen Gott und ihren Nechsten dermahleins dienen / oder sonsten ihr Handel und Gewerbe treiben wollen, zu einem dienlichen Unterricht mitgetheilet von Caspar Elvers, Past zu St. Joh. und des Stadt Consistorii Assessor. Cum Gratiâ \& Privilegio Sac. Imper. Majest. Russ. Riga, 1748

Versuch einer Naturgeschichte von Livland, entworfen von J. B. Fischer. Leipzig: verlegts Johann Gottlob Immanuel Breitkopf. 
Fraenkel $=$

Fürecker $1997=$

Fürecker $1998=$

Janaus, Māra. 1995.

Janaus, Māra. 1999.

Karulis, Konstantīns. 1992.

Kurmin, Jan. 1858.

Lange, Jacob. 1772.

Lange, Jacob. 1773.

Langijs $1685=$

Lavrinoviča, Ilze. 2016.

LD II =

LVDA $=$

Mancelius Lettus $1638=$
Fraenkel, Ernst. Litauisches etymologisches Wörterbuch, 1-2, Heidelberg: Carl Winter-Gottingen: Vandenhoeck \& Ruprecht, 1955-1965.

Lettisches und Teutsches Wörterbuch zusahmen geschrieben und mit fleiß gesamlet Von Christopher Fürecker. - Trevor G. Fennell. Fürecker's dictionary: the first manuscript, Rīga: Latvijas Akadēmiskā bibliotēka, 1997.

Christoph Füreckers Candidat des Predigtamts in Kurland lettisch-deutschen Wörterbuchs erster theil A-P, zweÿter Theil R-Z. - Trevor G. Fennell. Fürecker's dictionary: the second manuscript, Rīga: Latvijas Akadēmiskā bibliotēka, 1998.

Janaus, Māra. Melnais stārkisis. Latvijas daba. Enciklopēdija. 3. sēj. Kod-Miķ. Atb. red. Guntis Kavacs. Rīga: Latvijas Enciklopēdija, 1995, 217-218.

Janaus, Māra. Latvija - stārḳu zeme. Rīga: Latvijas Zinātnes un dialoga centrs, 1999.

Latviešu etimolog̣ijas vārdnīca, 1-2. Rīga: Avots.

Słownik polsko łacinsko łotewski, ułożony i napisany przez xiędza Jana Kurmina. Wilno.

Vollftängiges Lettifches Lexicon, famt angezeigten verfchiedenen Provinzialdialekten in Lief- und Kurland. Schloß Ober=Pahlen.

Lettifch-Deutfcher Theil des volftändigen Lettifchen Lexici, darinnen nicht nur sämtliche Stammwörter diefer Sprache famt ihren Abftämlingen, fondern auch die feltene, nur in gewißen Gegenden gebräuchliche Wörter, zum Nachfchlagen, angezeigt werden. Schloß Ober $=$ Pahlen.

Lettifch-Deutfches Lexicon worinnen Der Lettifchen Sprachen Gründe, Wörter, Bedeutung vnd Gebrauch in deutfcher Sprachen gezeiget vnd erkläret werden. Sampt einer kurtzen Grammatica, wodurch Den Außländern ein richtiger Weg gewieJen wird zur Erlernung der Lettifchen Sprachen leichtlich zukommen, geftellet vnd außgegeben von Johanne Langio, Paftoren zur Ober vnd Nieder $=$ Bartaw in Curland. $-N \bar{i} c a s$ un Bārtas mācītāja Jāna Langija 1685. gada latviski-vāciskā vārdnīca ar īsu latviešu gramatiku. Pec manuskripta fotokōpijas izdevis un ar īsu apcerējumu par Langija dzīvi, rakstību un valodu papildinājis E. Blese. Rīga: Latvijas Universitāte, 1936.

Lavrinoviča, Ilze. Stārkị - svētelis vai tomēr negants gaḷēeājs? [Māras Janaus atziņas]. Latvijas Avizze, 13. septembris 2016 https://www.la.lv/starkis-svetelis-vai-tomer-negants-galedajs Latvijas daba. Enciklopēdija, 2 Don-Kṇ. Rīga: Latvijas Enciklopēdija, 1995.

Latviešu valodas dialektu atlants. Leksika. Rīga: Zinātne, 1999.

Das ift Wortbuch / Sampt angehegtem täglichem Gebrauch der Lettifchen Sprache; / Allen vnd jeden Außheimifchen / die in Churland / Semgallen vnd Lettifchem Liefflande bleiben / vnd fich redlich nehren wollen / zu Nutze verfertigt / Durch / GEORGIVM MANCELIVM Semgall. der H. Schrifft Licentiatum \&c. Erster Theil. Gedruckt vnnd verlegt zu Riga / durch Gerhard Schröder / Anno M. DC XXXVIII [1638]. 
Mancelius Phr. $1638=$

Manuale $=$

Mažiulis, Vytautas. 1988.

$\mathrm{ME}=$

Smoczyński, Wojciech. 2007.

Stender 1789 I-II =

Toporov, Vladimir N. 1979.

Ulmann, Carl, Cristian.

1872 .

Urbutis, Vincas. 1981.

Urbutis, Vincas. 2002.

Waldemars $1872=$

Wörter-Büchlein 1705 =
PHRASEOLOGIA LETTICA, Das ift: Täglicher Gebrauch der Lettifchen Sprache. Verfertigt / durch GEORGIUM MANCELIUM, Semgallum, der H. Schrifft Licentiatum \&c. Ander Theil. Diefem ift beygefüget das Spruchbuch Salamonis. Zu Riga Gedruckt vnnd Verlegt durch Gerhard Schröder/ 1638.

Manuale Lettico-Germanicum 1-2. The text of the original manuscript transcribed by Trevor G. Fennell, Rīga: Latvijas Akadēmiskā bibliotēka, 2001.

Mažiulis, Vytautas. Prūsų kalbos etimologijos žodynas, 1. A-H. Vilnius: Mokslas, 1988.

Kārla Mülenbacha Latviešu valodas vārdnīca 1-4. Redigēejis, papildinājis, turpinājis Jānis Endzelīns. Rīga: Izglīitîas ministrija, 1923-1932.

Sabaliauskas, Algirdas. 1990. Sabaliauskas, Algirdas. Lietuvių kalbos leksika, Vilnius: Mokslas, 1990.

Schiller, Karl; Lübben, August. Mittelniederdeutsches Wörterbuch, 1-5. Bremen: Verlag von J. Kühtmann's Buchhandlung, 18751880; 6, Bremen: Verlag von Hinricus Fischer, 1881.

Stownik etymologiczny języka litewskiego. Vilnius: Vilniaus universiteto leidykla.

Lettisches Lexikon. In zween Theilen abgefasset, und den Liebhabern der lettischen Litteratur gewidmet von Gotthard Friedrich Stender, Präpofitus emeritus zu Selburg, Paftor zu Selburg und Sonnaxt, und der k. d. G. zu Göttingen M. Mitau, gedruckt bey I. F. Steffenhagen, Hochfürftl. Hofbuchdrucker [1789]

Prusskij jazyk. Slovar'. E-H. Moskva-Leningrad: Nauka.

Lettifches Wörterbuch. Erfter Theil. Lettifch-deutfches Wörterbuch von Bifchof Dr. Carl Chriftian Ulmann, Riga.

Baltu etimologijos etiudai. Vilnius: Mokslas.

Pastabos dèl latvių kalbos atlase aiškinamų žodžių kilmės. Baltistica 36(1). 5-18.

Krievu-latviešu-vācu vārdnīce. Москва: Tautas Apgaismošanas Ministerija, 1872.

Wörter-Büchlein / wie Etzliche gebräuchliche Sachen auff Teutsch / Schwedisch / Polnisch und Lettisch / zu benennen feynd. Riga (1705) (Atkārtots izdevums: „Wörter=Büchlein“ Vārdnīciņa, kā dažas parastas lietas tiek dēvētas vācu, zviedru, poḷu un latviešu valodā. 1705. gadā Rīgā iznākušās vācu, zviedru, poḷu-latviešu vārdnīcas faksimiliespiedums. Ar P. Vanaga komentāriem un latviešu vārdu indeksu. Stokholma: Memento, 1999.)

Ilga Jansone

Latvijas Universitātes

Latviešu valodas institūts

Akadèmijas laukums 1, Rīga, Latvija

ilgajan@lza.lv 


\title{
SUMMARY
}

\section{Stork (German Storch) in Latvian Lexicographic Sources}

\author{
Ilga JANSONE
}

The article provides an insight into the lexicographic sources of the $17^{\text {th }}-19$ th century, as well as the names of the stork included in the K. Mühlenbach and J. Endzelinns' Latviešu valodas vārdnīca.

In the ornithological literature, reliable evidence of the presence of storks in the territory of Latvia can be found from 18th century publications, but it is mentioned that the black stork has been found in Courland even earlier.

Latvian historical dictionaries of 17th-19th century contain 15 names with phonetic and morphological versions. G. Mancelius Phraseologia Lettica had already recorded the names žuguris and žuburis, which also appear in most later dictionaries. The common name for stork (borrowed from Middle Low German stork) with its phonetic and morphological variants appears in lexicographical sources in the second half of the 17th century - in K. Fürecker's dictionary, published only at the end of the 20th century after two different transcripts, in one of which appears stohrks and in the second - stahrks. At the end of the 17th century, it appeared, among other names, in E. Glück's translations of the Bible. In addition, the names of the stork are found in dictionaries, which coincide with the names of other birds, such as kokadzerve, gārnis, dzēse. Some stork names include bird-specific features, such as klabata, melnsprāklis. The names svêtelis and svêtputns (svêts putns) reveal a connection with mythological notions. The names žigur- and žı̆gur-could be a misinterpreted form of J. Lange from žugur-, because no source has been able to state that storks would be called žigurs. It is the name of a sparrow, which is distributed in a relatively wide area in the north and northeast of Vidzeme, as well as in the north of Latgale. The stork name sandarts recorded in J. Langius dictionary could also be a mistake. Other 17th-19th century dictionaries mention the names bugure, dzēstrs and žugdre.

K. Mühlenbach and J. Endzelīns' Latviešu valodas vārdnīca include almost all the terms for stork in the dictionaries, distinguishing several phonetic and morphological variants in separate entries. A number of occasional or rare names have also been registered, such as cikoniņš̌, krulla, parkšksis, stērga, stikāns, viesturs.

The diversity of stork names indicates a relatively recent nesting of a bird (especially a white stork) in the territory of Latvia, as well as the emergence and motivating features of its names: assimilation of the name to the names of already known birds (dzērve, gārnis, dzēse), inclusion of characteristic features in the name (klabata, melnsprāklis, parkšşis), connection with mythological notions (svêtelis, svêts putns). This hypothesis is also confirmed by the fact that the names of the stork mostly do not form compact dialectal areas. 


\title{
MĀLPILS DRAUDZES MĀCĪTĀJA OTO ROBERTA FON KLOTA (1808-1876) SPREDIḲIS LATVIEŠU VALODĀ 1851. GADĀ
}

\author{
Dzintra PAEGLE, Pēteris VANAGS \\ Latvijas Universitāte
}

\section{Ievads}

Rakstā pievērsīsimies mācītāja Oto Roberta fon Klota (Otto Robert von Klot) sprediķim (LVVA 1851), kas lasīts latviešu draudzei 1851. gada 11. oktobrī Rīgas apriņķa Mālpils Evaņgeēiski luteriskajā baznīcā vizitācijas laikā. Aplūkosim mācītāja ar roku rakstītā sprediķa saturu un izteiksmi, analizēsim ortogrāfiju, substantīvu, adjektīvu, pronomenu, verbu un prepozīciju lietošanu, apskatīsim dažas sintakses un interpunkcijas īpatnības.

Sprediķa citātos saglabāta orig̣ināla ortogrāfija un interpunkcija, bet pārsvìtrotais $<\mathrm{f}>$ aizstāts ar $<\dot{s}>$.

\section{Roberta fon Klota dzīvesceḷš}

Oto Roberts fon Klots dzimis Nìtaures pastorātā 1808. gada 12. februārī mācītāja, Latviešu literārās jeb draugu biedrības dibinātāja un pirmā prezidenta Gustava Reinholda fon Klota (Gustav Reinhold von Klot, 1780-1855) ğimenē.

Oto Roberts fon Klots viņa dzīves laikā biežāk ir saukts par Robertu fon Klotu, arī par Robertu Oto Klotu, tāpēc šajā rakstā turpmāk lietosim viņa galveno priekšvārdu - Roberts, kā arī iniciāli R.

No 1827. līdz 1830. gadam R. Klots studējis Tērbatā teoloǵiju, studijas turpinājis Berlīnē. Tad bijis mājskolotāis Umurgā. No 1842. līdz 1869. gadam mācītājs Mālpilī. 1869. gada 8. decembrī emeritēts. Līdzās draudzes darbam Mālpilī R. Klots no 1850. līdz 1856. gadam bija skolu revidents Rịgas apriņkīi, no 1856. līdz 1872. gadam - Vidzemes laukskolu virsvaldes padomnieks (Schulrat) (Bearent 1977: 296-297; DBL 389-390; Švābe 1958: 174).

Skolotājs Kārlis Rinkužs (1886-1947), aprakstot Vidzemes skolotāju semināra vadītāja Jāṇa Cimzes (1814-1881) darbību un viņa attieksmes ar šūlrātu R. Klotu, min šādus datus par Klota skolu padomnieka amata laiku no 1856. gada 22. marta līdz 1871. gadam (Rinkužs 1938: 74).

Meklējot plašāku informāciju par R. Klotu tā perioda laikrakstos, atrodamas ziņas, ka 1842. gada 15. janvārī Rīgas Jēkaba baznīcā R. Klots iesvētīts par Mālpils draudzes mācītāju (DI 1842, TLD 1842). 


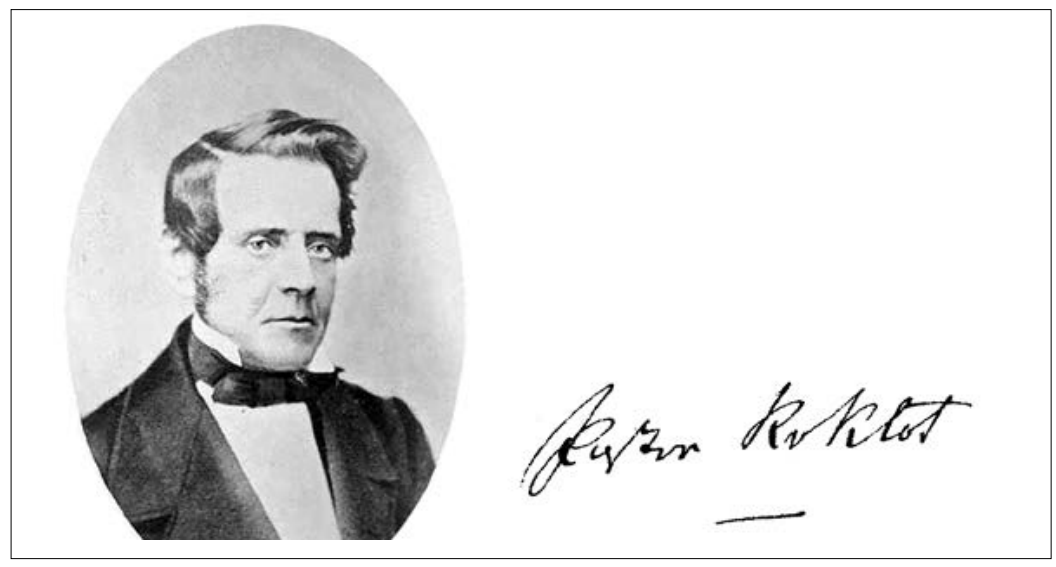

1. att. Roberts fon Klots un vinga paraksts (LVVA, 233. f., 4. apr., 1170. 1., 18. lp)

„Latviešu Avīzēs“ par R. Klota Vidzemes skolu priekšnieka amata uzsākšanas laiku varam uzzināt no E. Dinsberga raksta par Jāņa Cimzes goda dienu. Tur stāstīts, ka 1856. gadā Dr. Ulmanis pārcēlies uz Pēterburgu par augstāko baznīcas tiesas priekšnieku, viņa vietā par Vidzemes skolu priekšnieku iecelts Mālpils mācītājs fon Klots (LA 1864). Bet jau 1857. gadā laikraksts „Das Inland“ ziņo, ka par laukskolu padomnieku viņš kḷuvis 1856. gada martā (DI 1857). Pēc tam, kad 1869. gada 8. decembrī R. Klots ir beidzis darbu Mālpils draudzē, viņš̌ vēl ir palicis amatā par Vidzemes laukskolu priekšnieku (RK 1870). Pēc diviem gadiem, 1871. gada beigās, Klota vietā par Vidzemes skolu priekšnieku ievēlēts mācītājs Teodors Pfeils (Theodor Pfeil, 1828-1913) no Tērbatas (BV 1871).

R. Klota Vidzemes skolu priekšnieka amata laikā ir palielināiies skolu skaits, viņa atskaitē 1856. gadā ir bijušas uzrādītas 103 draudzes skolas un 524 pagastskolas, bet savā pēdējā ziņojumā 1869./70. gadā Klots uzrāda jau 111 draudzes skolas un 811 pagastskolas (RZ 1876).

R. Klots sava amata laikā reizi gadā turpinājis noturēt Turaidā skolotāiju seminārus, kas aizsākušies 1848. gadā. Par to ziņo laikraksti „Mājas Viesis“, „Latviešu Avīzes“, „Baltijas Vēstnesis“. „Mājas Viesis“ apraksta sīkāk, kā noritējis skolmeistaru saiets 1863. gada 26. jūnijā. Tas noticis Turaidas Šveicera mājas lielajā istabā (zālē), bija ieradušies kādi 70 vīri. Semināru sākuši ar dziedāšanu, tad - R. Klota dievvārdi, pēc tam nolasīts pagājušā gada semināra protokols, lai visi zinātu, kas tur runāts. Tad pārsprieduši skolas lietas. Pēc pusdienām izgājuši ārā uz pils torni, tur zem ozoliem daudzbalsīgi 
dziedātas dziesmas Limbažu skolmeistara Šmita kunga vadībā. Un atkal telpās pārrunājuši skolu lietas, strādājuši līdz plkst. 6.30 vakarā, nobeigumā ārā četrbalsīgi dziedājuši tautas dziesmas un „Was ist des Deutschen Vaterland“ un „Unter allen Wipfeln ist Ruh“. Bijuši arī klausītāii. Seminārs turpinājies otrajā dienā (MV 1863). Par R. Klota darbības laiku Vidzemes laukskolās plašāk rakstīịis A. Vičs (1928: 318-433).

Laikrakstos var atrast ziņas, ka pēc amata atstāšanas Mālpilī R. Klots dzīvojis Rīgā un savā dzīves vietā ir izplatīịs dziedātājiem „Dziesmu rotu jaunekļiem un vīriem“ I un II daḷu J. Cimzes redakcijā un iekasējis Atraitņu un bāriņu palīdzības lādes biedru naudu no skolmeistariem. Rakstā ir uzrādīta vecā skolu priekšnieka Klota dzīves vieta: Rīga, Pēterburgas priekšpilsēta (Vorstadt), Lielā Smilšu iela Nr. 31, paša namā (Große Sandstraße No 31, im eigenen Hause) (MV 1872).

Roberts fon Klots miris 1876. gada 15. martā Rīgā, apglabāts, domājams, Jēkaba draudzes kapsētā (RK 1876).

\section{Roberta fon Klota sprediķa saturs un izteiksmes īpatnības}

Mālpils baznīcas vizitācijas laikā 1851. gadā mācītājam R. Klotam ir 43 gadi un 9 gadu pieredze mācītāja darbā. K. Rinkužs (1938: 74) R. Klotu raksturojis šādi: „Klots bija maza auguma, pavājš miesās, tomēr enerğisks un noteikts. Viņš bija konservātīvs un nosvērās uz muižnieku reakcionārā spēka pusi."

Pievērsīsimies dažām sprediḳ̂̄ paustajām domām un izteiksmei.

Pēc ievadvārdiem R. Klots uzrunā draudzi ar visai demokrātisku frāzi - Mīl li ticības biedri! Tomēr uzruna nav oriğināla. Piemēram, aplūkojot „Seniespiedumu kopkatalogu“, redzams, ka ar šādu uzrunu virsrakstā ir apzināti trīs nelieli iespiedumi: divi izdevumi ar Georga Sokolovska paziņojumu „Mīli ticības biedri!“ par žurnālu „Ziņas par Notikumiem iekš Dieva Valstības“ 1832. gada novembrī un decembrī, tie iznākuši Straupes baznīcas kunga muižā, un Krievijas Bībeles biedrības uzaicinājums „Mīli ticības biedri no Latviešu tautas“ 1845. gadā, 2 lpp., bet šā uzaicinājuma neviens eksemplārs nav saglabājies (Seniespiedumi 1999: Nr. 1820, 499; Nr. 1319, 378).

Spredikisis Mālpilī notiek darbdienā, nevis svētdienā, kā parasts, jo tā ir noteikusi baznīcas valdīšana. Mācītājs aizrāda, ka tomēr ir vērts aizkavēt dienas darbu, jo „viena diena iekš taviem pagalmiem labāka nekā tūkstošas citas“:

Mihli tizzibas beedri! Juhs śchodeen śchè śchurp eśśat śaaizinati śchinnî śawâ Deewa-nammâ. - Bet woi tad śchodeen kahda śwehdeena? - Woi 


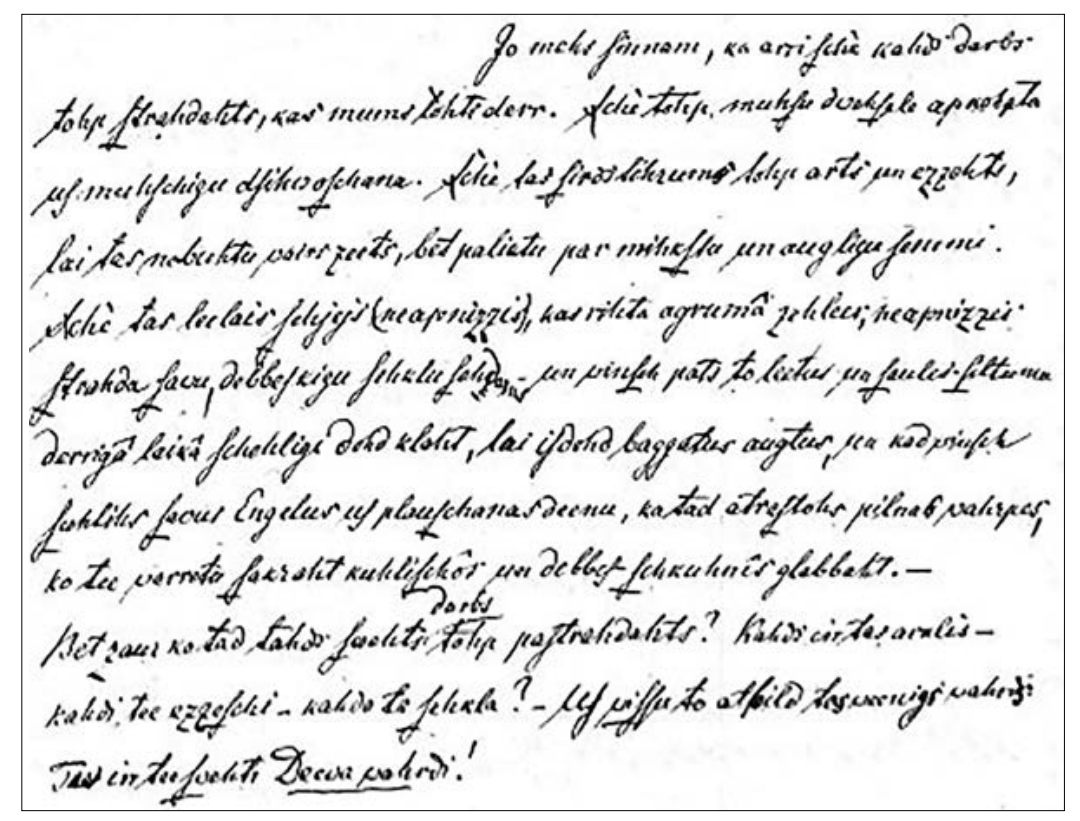

2. att. Roberta fon Klota sprediķa fragments (LVVA 1851: 198. 1p. o. p.)

tad śchee kahdi śwehtki? - Ne, m. t. b., ta gan naw. Bet śchi deena mums nolikta no bafnizas-waldiśchanas preekśchneekeem, pahrraudfiht ścho draudfi un apluhkoht, woi ta Deewa-kalpośchana pee mums noteek kà waijaga, - woi behrni tohp audfehti eekśch ta Kunga Jefus atfihśchanas un pamahziśchanas, - woi laulati draugi mihleśtibâ un śaderribâ dfihwo, - woi ikweens darbojahs eekśch tahm Deewa leetahm, un woi wiśśa śchi draudfe arri dfennahs, tahda draudfe palikt ikdeenas jo wairak, kurrai nebuhtu ne-kahds traipeklis, nedf grumba, nedf zitta kahda waine, bet kas buhtu śwehta un befwainiga, - weena ihśtena Kriftus-bruhte. Bet kahdę śchi leeta naw nolikta uf kahdu śwehdeenu? Kapehz mums nu irr ja-aifkaweh śawu deenas-darbu? - M. t. b., ja ta kahds praśśa, tahds teeścham arri buhtu kuhtris śwehdeenâ śchurp atnahkt. - Bet mehs, kas mahzijuśchees śazziht ar kehningu Dahwidu (26,8): „Kungs, es mihleju to mahjas weetu tawa nā̄a un tawas gohdibas telts-weetu“, mehs arri leezinajam ar to pafchu (Dahw: 84,12): „Weena deena eekśch taweem pagalmeem, ak Kungs, irr labbaka neka tuhkśtośchas zittas. "Jo mehs finnam, ka arri śchè kahds darbs tohp śtrahdahts, kas mums lohti derr. (LVVA 1851: 198. lp.) 
Mācītājs, dvēseles kopšanu tēlodams līdzībās ar zemniekiem tik pazīstamo tīruma aršanu un ecēšanu, saka:

Śchè tohp muhśu dwehśele apkohpta, uf muhfchigu dfihwośchana [tā!]. Śche tas sirdstihrumà tohp arts un ezzehts, lai tas nebuhtu wairs zeets, bet paliktu par mihkśtu un augligu femmi. Śchè tas leelais śehjejs (neapnizzis), kas rihta agrumâ zehlees; neapnizzis śtrahda śawu, debbefkigu [tā!] śehklu śehdams - un wiņśch pats to leetus un śaules-śiltumu derrigâ laikâ fchehligs dohd klaht, lai ifdohd baggatus auglus, un kad wingśch śuhtihs śawus Engelus uf plauśchanas deenu, ka tad atraśtohs pilnas wahrpes, ko tee warretu śakraht kuhliśchôs un debef-śchkuhnîs glabbaht. - Bet zaur ko tad tahds śwehts darbs tohp paftrahdahts? Kahds irr tas arklis - kahdi tee ezześchi - kahda ta śehkla? Uf wiśśu to atbild tas weenigs wahrds: Tee irr tee śwehti Deewa wahrdi! (LVVA 1851: 198. 1p. o. p.)

Mācītājs R. Klots garīgo dzīvi, kalpošanu Dievam tēlo romantiski, gaišās krāsās, tā līdzinās zemes kopšanai, labības sēšanai, audzēšanai un bagātas ražas novākšanai. Dieva vārdus viņ̌̌ salīdzina ar „rihta śauliti pehz nakts-tumśibas“ (LVVA 1851: 199. lp. o. p.), kā arī „Woi ar ścho śaldu peenu ne eśśam ari mehf meerinati“ (LVVA 1851: 201. lp.). Minētajos sprediķa fragmentos iezīmējas romantisms, kas, pēc Ināras Klekeres domām, jau 1816. gadā veidojās Berlīnes Universitātes mācībspēku vidū (Klekere 2011: 91), un Berlīnē ir studējis arī R. Klots.

Tomēr romantisms R. Klota sprediķ̄i izpaužas fragmentāri, tāpat kā 18. gs. beigās dzejas publikācijās, kā to novērojusi I. Klekere (2011: 105).

Mācītājs Klots vēršas pret tiem, kas savu ticību nav pienācīgi kopuši, un salīdzina tos ar nevī̌žìu zemkopi:

Kàdehl tu to femmi licis maitaht no paśaules kahjahm un ratteem? Kàdehl tu to nenokruftijis kà Kriftus apśehtu tihrumu. Kàdehl tu to neaptaiśijis ar śehtahm un ar grahweem un aifdfinnis tohs putnus? (LVVA 1851: 200. 1p.)

Te aprakstīta arī etnogrāfiska zemkopības aina, kas jau 20. gs. sākumā ir zudusi. To piemin valodnieks Juris Plāksis, raizējoties par sena zemkopības veida iznīkšanu un reizē arī vietvārdu zudumu. J. Plāksis (1936: 1) ir novērojis: „Gluži tāpat pazuda nosaukumi senajiem aptaisītajiem un apžogotajiem dārziem jeb laukiem, kad iznīcināja sētas un žogus un laukus pārkārtoja un pārdalīja pēc jauniem lauksaimniecības paraugiem.“

Šajās iepriekš citētajās Klota sprediķa rindās ieskanas aicinājums uz kristīga zemnieka ideālu izturēšanos - pielūgt Dievu un pārmest 
krustu apsētam laukam. Šādu zemnieka dievbijību baznīca audzinājusi gadsimtiem ilgi.

Simboliski putns kā ḷaunums, kas iznīcina dvēselē sētu Dieva sēklu, Klota sprediķ̄ minēts atkārtoti: ,„...] tai dwehśelei, kas teem putneem lạhwuśi, to labbu śehklu apehśt" (LVVA 1851: 200. lp.).

Mācītājs R. Klots spredikịī vismaz divas reizes vēršas pret tiem, kas pāriet svešā ticībā un cer uz pasaules labumiem: „kas pee śchihs draudfes bija peelikti no mafahm deenahm, atśchkihrahs no mums un zittu śwefchu tizzibu kahroja - zerredami paśaules labbumus“"(LVVA 1851: 201. lp. o. p.); „kas zittam Kungam kalpo, neka tam trihf w eenigam Deewam - prohti tai paśaulei - woi śawam wehderam“ (LVVA 1851: 200. lp.).

19. gs. vidū no Mālpils luteriskās draudzes pārgāja pareizticībā 400 cilvēku (KV 1911: 2587), bet no kaimiņu Suntažu draudzes - 1500 cilvēku (KV 1921: 4071), mazliet mazāk nekā puse suntalnieku. Vēsturniece Ieva Pauloviča, aprakstot Mālpils Dievmātes Patvēruma Pareizticīgo draudzes darbību, balstoties uz arhīva dokumentiem, piemin, ka tēvam Aleksejam Lavrovam, „kurš te darbojās no 1847. gada līdz 1858. gadam, [..] bieži nācās aizstāvēt savā draudzē pārgājušos zemniekus, īpaši cīnoties ar Mālpils Luterāņu draudzes mācītāju Oto Robertu fon Klotu, kurš savukārt darīja visu, lai atrunātu zemniekus pāriet pareizticībā, un nosodīja tos, kuri to izdarīịa“ (Pauloviča 2011: 1/11).

R. Klota rīcība vērtējama kā drosmīga, jo cariskajā Krievijā ar represijām vērsās pret tiem, kas bija pret pareizticību. Toreiz, 1846. gadā (spredikịis tiek lasìts 1851. gadā), par šādu rīcību tika slēgts laikraksts „Tas Latviešu Draugs" un tā izdevējs mācītājs Hermanis Treijs (Johannes Hermann Trey) izsūtīts uz Kauņu, represijās cieta arī laikraksta cenzors K. E. Napjerskis (Carl E. Napiersky) (Par to Klekere 2011: 50; Zelče 2009: 155-157).

R. Klots ir neiecietīgs arī pret tiem, kas piekopj elkdievību, teikdams, „kas śawu dwehśeli prettineekam nodewuśchi un kas viņņus mahza pagahnu śkohlâs“. Mācītājs spredikīi min negatīvā nozīmē gan pagānu skolas, gan elkdievību, to pielīdzinādams citiem smagiem kristīga cilvēka grēkiem. Viņš atsaucas uz Svētajiem Rakstiem (1 Kor 6,9): „Nepeewileetees; nedf mauzineeki, nedf elka-deewigi, nedf laulibas pahrkahpeji, nedz mihkftneeki, nedf fagli, nedf negauśchi, nedf dfehreji, nedf lazzekli, nedf laupitaji to Deewa walśtibu neredfehs.“ (LVVA 1851: 201. lp. o. p.) Šajā pārmetumā vārdu savienojums elka dievīgi ir iekḷauts starp daudziem negatīvas nozīmes vārdiem, kurus tagad publiskā runā neatḷaujamies lietot un kuri vairs nepieder pie vispārlietojamās leksikas. Te līdzās elka dievīgiem un laulības pārkāpējiem, minēti mīkstnieki 'g]̣̣ēvuḷi, raudulị' (ME II 643 mîkstnieks, arī 
mîkstulis, ein Weichling, Zärtling), zagli, negauši, dzēēẹi 'dzērāji', laceklıi 'zaimotāji, apmelotāji, mēlneši' (ME II 399 II laceklis, der Verleumder, Lästerer), maucinieki 'staiguli, netikḷi’ (ME II 568 maũcinieks, ein Hurer) un laupītäji.

Mācītājs ar piemēriem rāda, kā Dieva vārds var mierināt lielās bēdās, kad mātes apraud savus mirušos bērnus. Viņš sniedz spilgtu bēdāšanās ainu:

Zik no jums mahtes, kad śchinnî draudfê brehkśchana tappe dfirdeta kà eekśch Ramas (Math. 2, 18), fchehlośchana, raudaśchana un daudf kaukśchanas, un daudf Raëles muhśu śtarpâ apraudaja śawus behrnus un negribbejahs eepreezinajamas, jo tee nebija wairs, — zik tad no jums apbehdinatahm mahtehm irr atśpirguśchees pee teem wahrdeem ta Kunga, kas śakka: „Taws behrninśch naw wifs nomirris, bet tas dufs - un ef win̨nu ufmohdinafchu paftaras-deenâ!“" (LVVA 1851: 201. lp.)

Uz sprediķa beigām, apliecinādams Dieva klātesamību Dievnamā, R. Klots saka: ,... arri pats tas Kungs un Peftitajs irr nośtahjees muhśu widdû apraudfiht ścho śawu draudfi.“ (LVVA 1851: 202. lp.)

Šajos piemēros vērojama mācītāja emocionalitāte un izteikšanās veids. Viņš, izceḷot kādu domu, kārto virknēs sinonīmiskas nozīmes vārdus, panākdams spēcīgāku ekspresivitāti, ko uzskatāmi rāda vairāki sprediķa fragmenti, piemēram, skaļa bēdāšanās apzīmēta: fchehlośchana, raudaśchana un daudf kaukśchanas. Dzīves grūtību tēlojumā minēts bads, likstas, vajāšana, sitieni un cietums: „kas baddu un likśtu - waijaśchanas un śitteenus - un zeetumu paneśśis“ (LVVA 1851: 201. lp.). Turpat tālāk: „Kas muhf śchkirs no Kriftus mihleftibas - woi debbef, jeb bailiba jeb waijaśchana, jeb badds, jeb plikkums, jeb likśta, jeb zobins?“ (LVVA 1851: 201. lp.) Tie, kas nepievēršas Dieva mācībai, raksturoti ar spēcīgu salīdzinājumu: „Mehf gullam un śnaudam kà mirroņu śchkirśtî, un nezillajam nedf kahjas nedf rohkas pee ta ihśtena Deewa-darba prohti muhśu śwehtiśchanas, muhśu śirds irr kà akmiņs un klints - neaugliga femme.“ (LVVA 1851: 199. 1p.) Starp salīdzinājumiem ir savdabīgs: ,.. behdas un śahpes [..], kas mums ufkriht kà kahds śtipri apbruņohts wihrs“ (LVVA 1851: 200. lp. o. p.). Pievēršanu ticīgo dzīvei mācītājs tēlo kā darba procesu, kurā izmantots āmurs un arkls: „Ścho niknu śirdi, kas zeeta kà klints, wiņfch śagraufch ar to ahmuri, kas kalnus śaśitt; ścho neaugligu femini wiņśch ufplehśch ar to aśchu arkli śawas bauślibas .." (LVVA 1851: 199. 1p., 199. 1p. o. p.)

Garīgās dzīves kopšana, cilvēka dvēsele, iekšējā pasaule tiek asociēta ar sirdi. Sirds spredikīī tiek minēta daudzkārt (19 reižu): Śchè tas śirds tihrums tohp arts un ezzehts; muhśu śirds irr kà akmings; śawahs śirds bail ês kleedf; tad eekriht tannî śi rdî kà labb-śataiśihtâfemêê; śawu śirdi irr 
atwehris; Teeścham ta dfihwibas śaulite arri śchè irr atśpihdejuśi daudf śi $r$ î̀ s ; arri pee tawas śi rds zittkahrt tas bauślibas arklis tikke peelikts to ufplehśt; ścho śtundinu eekśch tawas śi rds kriht tà glabbaht; zik reif tu apbehdinahts śazzijis śawấ śirdî̀; ar śirds behdahm; pee śirds leekam; Dewwawahrds irr [..] śohgis to dohmaśchanu un śirds apñemśchanu 'apñemšanos'; ja mehs sawu śi rdi gribbetu dalliht un diwi Kungeem kalpoht; eśśam mannijuśchi peeśawas śirds; bet Deews ufluhko to śirdi; kurirrta śirds, ne kas kalpo wehl dafcheem deewekleem, ko pee śewim turr?

Starp vārda sirds lietojumiem ir arī frazeolog̣ismi, piemēram, jaraud sawâ śirds dibben â. Vārdu savienojums sirds dibenā uzskatāms par novecojušu, tagad - sirds (dvēseles) dzilumos (LFV II 1996: 366). Savdabīgs izteiciens nikna sirds, kas cieta kā klints: Ścho niknu śi r di, kas z e e ta kà klints, sal. cieta sirds 'saka, ja cilvēks ir neiejūtīgs, nežēlīgs, cietsirdīgs' (LFV II 1996: 346). Klota izteicienu varētu uzskatīt par pārveidotu frazeolog̣ismu. Frazeolog̣isms likt pie sirds: lai to pee śirds leekam a r nozīmi 'cenšoties ietekmēt kādu, sirsnīgi ko ieteikt' (LFV II 1996: 354) atbilst mūsdienu valodai.

\section{Roberta fon Klota sprediķa valodas īpatnības}

\subsection{Ortogrāfija}

R. Klota spredik̄ī lietotā latviešu valodas ortogrāfija lielā mērā atbilst 19. gs. pirmās puses rakstībai, tāpēc pilnībā to šeit neaprakstīsim. Viņa jauninājums varētu būt vienkāršā $<\mathrm{v}>$ lietošana dubultā $<\mathrm{w}>$ vietā: voi ikveens darbojahs eekśch tahm Deeva leetahm. Atsevišksos gadījumos ir tomēr rakstīts skaidrs dubultais $<\mathrm{w}>$ : Voi tad śchee kahdi śvehtki? - Ne, m. t. b., ta gan naw; Weena deena eekśch taweem pagalmeem; Tee irr tee śvehti Deeva wahrdi. Reizēm grūti izšksirt, kura no grafēmām lietota. Nav izslēdzama iespēja, ka škịetamais $<\mathrm{v}>$ tomēr ir tikai $<\mathrm{w}>$ rakstības paveids, nevis apzināts citas grafēmas lietojums. Tāpēc rakstā gan škietamais $\langle\mathrm{v}\rangle$, gan $<\mathrm{w}>$ apzīmēti ar tradicionālo $<\mathrm{w}>$.

Atšķirīgs no sava laika paraduma ir grafēmas $<\mathrm{x}>$ lietojums, lai apzīmētu skaņu kopu [ks] vārdā teksts: Par ścheem paścheem runna tee te x te s-wahrdi; No śchi Deewa wahrda śakka muhśu tex tis .

R. Klots rokrakstā neapzīmē skaņu /ḳ/, bet raksta tikai $<\mathrm{k}>$ : Bet mehs, kas mahzijuśchees śazziht ar kehninu Dahwidu; neapnizzis śtrahda śawu, debbefkigu śehklu śehdams; debess śchkuhnîs glabbaht; muhs raht un śchkihśtiht; tur irr śchkelśchanas un śchkirśchanas. Rakstos netiek šksirts arī /g/ no /g̊g/, abus līdzskaņus apzīmējot ar $\langle\mathrm{g}\rangle$ : tohpam pahrwehrstiti eekśch Kriśtus Jefus gihmi; irr śohgis; abbeja puśśê greefigs fohbins. Reizēm netiek uzrādīts /1̦/ un /ņ/ mīkstinājums: deewekleem, fagli, engelus. 
R. Klots apzīmējis mīkstināto /ṛ/ pronomena kuṛš formās: zaur kurrra bruhzehm mehs eśśam dfeedinahti; darrija dfihwus, kurrrus gribbedams, bet citur, piemēram, Apuśt. Pehtera wahrdeem, /ŗ/ mīkstinājuma trūkst.

Nebalsīgais /s/ no balsīgā /z/ škirirts ar burta < $1>$ pārsvītrojumu: wiśśeem, śawâ, śwehdeenu; Jefus, bafnizas, finnam. Tāpat šḳirti /š/ un /ž/: fchehlośchana, śchinnî, eekśch; muhfchigas, dafcheem. Tomēr visai bieži $<1>$ pārsvītrojuma trūkst: muhfu, fehklu, tumfchi.

Prepozīcijas aiz, bez, $u z \mathrm{R}$. Klots raksta ar $\langle\hat{1}\rangle$ : kas irr bef traipekla un bef grumbas; kahdel śchi leeta naw nolikta uf kahdu śwehdeenu; tāpat arī prefiksu atvasinājumos: aifdfinis tohs putnus; befwainiga; lai ifdohd baggatus auglus; kas ufnehmuśchi to dfihwibas graudinu. Tajā paša laika periodā mācītājs F. V. Veirihs prepozīcijas rakstīịis ar $<$ s $>$ (Paegle 2019: 127). R. Klota sprediķa tekstā ar garo $<f>$ vārda galā visai bieži rakstīti arī pronomeni es, mēs: ef, mehf, kur tam noteikti nav fonētiska, bet tikai grafiska nozìme.

Negācija ne- tiek rakstīta ne vien šksirti no verba: ne allojahs, ne buhtu, ne eśmu, ne gribb, ne kalpo, ne taptu, ne-if'śakoht, bet arī koprakstījumā: nebuhs, negribb. Adverbs nekad rakstīts kopā, salīdzinājuma partikula nekā gan kopā: nekà, gan šķirti: ne kà, ne ka, bet saiklis nevien, bet arī kopā: neween - bet arri. Nomeni ar negāciju ne- rakstīti kopā: nenofeedfiba, nezeenigu.

Vārdu debess pamatformā R. Klots parasti raksta ar vienu $<\mathrm{s}>$ kā vārdu bez galotnes: debbes, bet citos locījumos ir lokāmā galotne: debbeśu-tehwa, debbesîis.

\subsection{Fonētika}

Dažos R. Klota rakstītos vārdos lietota fonētiska, nevis morfologíiska rakstība, piemēram, śwehdeena ar /t/ asimilatīvu zudumu. Adjektīvā kūtrs, tāpat kā daḷā vidus izlokšṇu, vārda beigās iesprausts /i/ galotnes -s priekšā: buhtu kuhtris śwehdeenâ śchurp atnahkt.

Pēc sava laika tradīcijas rakstīti vārdi waijaga, waijaśchana - ar $<\mathrm{i}>$ aiz $<$ a $>$ vai $<$ e $>$, ja nākamā zilbe sākas ar $<\mathrm{j}>$ (par to Bergmane, Blinkena 1986: 42). Formā ifeij uzsvērtā pozīcijā pagarināts ej (Pokrotniece 1991: 205). Imperatīva formās sakajt, dfennajtees divskaņa /ai/ otrais komponents rakstīts ar līdzskaņa grafēmu $<\mathbf{j}>$ tāpat kā Jēkaba Langes laikā (Pokrotniece 1991: 203).

R. Klota tekstā lietota forma akmings: Muhśu śirds irr kà akmings un klints - neaugliga femme; kas, ja vien nav rakstības kḷūda, ,rāda nepārveidotu $s$ vārda beigās pēc ņ, piem., cilvēcings“ (Pokrotniece 1991: 206), kā tas vērojams G. Manceḷa, E. Glika, J. Langes u. c. agrāku laiku autoru darbos. 


\subsection{Morfologija}

\subsubsection{Substantīvu formas}

Substantīvu lietošanā ir atsevišķas īpatnības - atš̌kirīga no mūsdienām vārda pamatformas galotne un deklinēšana. Substantīvu o-celmu vietā lietoti iio-celmi: arklis: ar aśchu arkli; āmuris: ar to ahmuri. Dažu substantīvu ā-celmi aizstāti ar $\bar{e}$-celmiem, piemēram, vārpe: pilnas wahrpes; vaine: nedf no śavas grehku waines. Vārds ecēšas lietots vīriešu dzimtē: kahdi tee ezześchi. Tāda forma atrodama arī Stendera, Langes un Bergmaņa vārdnīcās (Zemzare 2011 [1961]: 351). Lietvārdi akmins, zobins, tāpat kā daudzu 18. un 19. gs. autoru darbos, lietoti ar -i- vēsturiskajā piedēklī: aśśaks ne ka abbejâ puśśê greefigs fohbins; paleek par aśśi un greefigu fohbini. K. Mīlenbaha „Latviešu valodas vārdn̄icā" zuobins uzrādīts kā viens no plašāk lietotajiem vārda variantiem tā laika vārdnīcās un Vidzemes izloksnēs (ME IV 756).

Tāpat kā J. Langes „Latviešu Ārstē“ (Pokrotniece 1991: 207), F. V. Veiriha spredikị (Paegle 2019: 129), arī R. Klota spredik̄i ir atrodamas $i$-celma formas ar senu īsu $<\mathrm{i}>$ dsk. datīva galotnē -im: kas preekśch a z zi m irr; pee śawahm kruhtim.

Lietvārds š̌nūnis lietots kā sieviešu dzimtes (?) i-celms dsk. lokatīvā (sal. vācu die Scheune): debess śchkuhnîs glabbaht. Iespējams, ka lietvārds šķirsts lietots kā iìo-celma substantīvs: Mehs gullam un śnaudam kà mirroṇu śkir śt $\hat{\boldsymbol{\imath}}$. Spredikī ir lietota $\bar{a}$-celma g̊enitīva forma no vārda mūžs: ścho muhfchas zellu śtaigajoht. Tas varētu rādīt rakstītāja nepiln̄̄gu latviešu valodas prasmi, kaut, iespējams, sieviešu dzimtes forma fiksēta arī citos avotos (ME II 680).

Starp daudzskaitliniekiem, tādiem kā aśśaras, behdas, mohkas, kildas, śehrgas, ir vārds vienskaitlī - zāle 'viela slimību ārstēšanai': Tee nav wifs ta fahle no Gilead, kas mums ihfteni derr, muhf weśśelus darriht.

\subsubsection{Substantīvu darināšana}

Substantīvu darināšanā visbiežāk izmantota izskaņa -šana, ar to substantīvi darināti no tiešo verbu nenoteiksmes celma. R. Klota spredik̄ī ir konstatēti šādi darinājumi - aicināšana: nedf no śawas a i zi n a śch a nas; apñemšana: irr śahzis to dohmaśchanu un śirds a p ņ em śch a nu; apzēlošana: tas tehws to apfchehlośchanu; atdzemdināšana: tas atdfemdinaśchanas śpehks to śwehtu Deewa-wahrdu; atdzīvināšana: atdfihwinaśchana; atzī̌sana: eekśch ta Kunga Jefus atfihśchanas un pamahziśchanas; bāršana: rahj par [..] bahrśchanu; brēkšana: kad śchinnî draudfê brehkśchana tappe dfirdeta; būšana: śawu nezeenigu buhśch an u noraudadami; ciešana: winnna zeeśchana; domāšana: un irr śohgis to domaśchanu un śirds apnemśchanu; draudēšana: ar śaweem dra udeśch a nas lahśteem; dzī̄ošana: 
uf muhfchigu dfihwośchana [tā!], Jefus dfihwośchana, no tahs Jefus dfihwośchanas; iekārošana: ar [..] meeśas eekahrośchanahm; iepriecināšana: eepreezinaśchanas mums teeścham vaijaga śchinnî behdu-muhfchâ, śpehzigu eepreezinaśchanu; kaukšana: fchehlośchana, raudaśchana un daudf ka u kśch a nas ; miršana: no tahs Jefus dfihwośchanas un mirśch anas; nopūšana: nekad nebuhtu ja-nopuhśchahs ar gruhtahm nopuhśchanahm; nìdēšana: rahj par [..] nihdeśchnu; paciešana: eekśch pazeeśchanas; pamācīšana: pamahziśchana; pazušana: pafuśchana; pāršksiršana: lihdf pahrśchkirśchanai tahs dwehśeles un ta garra; pestī̌sana: par to leelu peśti śch an as darbu śtahśta; pieñemšana: pe eñ em śch a nu eekśch wiśśa labba; plītēšana: rahj par [..] pli h teśch a nu; plaušana: uf plauśc ha nas deenu; raudāšana: raudaśch an a; sadraudzēšana: ta śa draudfeśch a na; staigāšana: winnna śt aiga śch a na; svêtī̄̌nana: muhśu śwehtiśchanas; šķelšana, šķiršana: tur irr śchkelśchanas un śch kirśch an as; taisnošana: un muhśu ta iśno śch a n as dehl; uzbraukšana: ta debbeśî ufbraukśch a na ta Kunga; vajāšana: kas behdu un likśtu vaijaśch a nas un sitteenus [..] paneśśis; valdī̌sana: bafnizas-wal diśch a na; zūdīšana: tur irr nemeeri un fuhdiśchana; žēlošana: fchehlośchana, raudaśchana un daudf kaukśchanas.

Atgriezeniskie substantīvi ar -šanās sprediķa tekstā nav lietoti, to vietā atrodami vairāki atvasinājumi ar -šana: apņemšana: irr śahzis to dohmaśchanu un śirds a p̧̧emśch anu (nevis apñemšanos); nopūšana: nopuhśchahs ar gruhtahm nopuhśchanahm (nevis nopūšanos); šķelšana, šķiršana: tur irr śchkelśchanas un śchkirśchanas (nevis šķ̧elšanās un šķiršanās).

Substantīvu ar -šana lietojums Klota valodā var atškirities no mūsdienu valodas ar gramatisko skaitli: śavu meeśu pee kruśta irr śittuśchi ar tahm kahribahm un meeśas e ekahrohśchanahm (nevis iekārošanu); [..] Jefus wahrdi - Jefus darbi - winnna zeeśch ana (nevis ciešanas) un nahwe pee kruśta.

Substantīvu atvasinājumi ar izskaņu -ība ir lietoti samērā daudz, tie ir vārdi, kas parasti arī mūsdienās: cerība: śawas muhfchigas z er ri ibas ; dievība: rahj par [..] Elka-deewibu; dzī̄ība: tahs muhfchigas dfihwibas; labprātība, laipnība: kas irr [..] labbprahtiba, laipniba; laulība: laulibas pahrkahpeji; līksmība: kas irr [..] li hg s mi ba; mācība: rahj par [..] wiltigahm mahzibahm; mīlestība: ta mihleftiba Dewa ta Tehwa; patiesība: eekśch tawas pateeśibas; saderība: woi laulati draugi [..] śaderribâ dfihwo; skaudība: rahj par [..] śkaudibu; slimība: tur irr śli īibas un śehrgas; ticība: Mihli tizzibas beedri; viltība: wilt iba naw atraśta; žēlastība: ta fchehlaftiba muhfu Kunga. 
Starp darinājumiem ar -ība ir tādi vārdi, kurus mūsdienās lieto reti vai nelieto nemaz: bauslība 'baušli, to mācība': tas ba ús li b a s arklis; bezvainība 'nevainība': zaur śawu befwai ni bu; kārība 'kārdinājums': tai paśaulei un winnas kahribahm; nenoziedzïba 'nevainība': zaur śawu n en ofe edfi bu . Dalıa atvasinājumu ir tādi, kam tagad ir cita nozīme, piemēram, burvība nenozīmē 'burvestība; buršanās', kā Klots to ir lietojis, bet gan 'neparasts skaistums': rahj par Elka-deewibu, bu rwibu. Vārdu tumsība tagad lieto ar nozīmi 'neizglītotība', nevis 'tumsa' kā sprediks̄i, kaut gan arī te ir nozīmes pārnesums plašākā kontekstā: śpihd kà rihta śaulite pehz nakts tu m śi ba s .

Daḷa tā laika darinājumu ar -ība mūsdienās vairs netiek lietoti, to vietā izmanto īsāku vārdu, piemēram, duśmiba 'dusmas', eenaidiba 'ienaids', bailiba 'bailes'. Jāpiebilst, ka Klota spredik̦ī atrodama gan bailība, gan bailes: Kas muhs śchkirs [..] jeb ba ilib a jeb waijaśchana; kurrôs gan no bail eh m bija ja-ifnihkft.

Līdz̄̄gi lietoti atvasinājumi ar izskaņu -ums. Te ir substantīvi, kas parasti mūsdienās: agrums: kas rihta agrumâ zehlees; cietums: kas [..] ze et u mu paneśśis; gaišums: lai tohs darram par [..] weenu g a iś ch u mu uf wiśśeem muhśu zelleem; labums: zerredami paśaules la bbumus; siltums: winśch [..] śaulesśil t u mu derrigâ laikâfchehligi dohd; tīrums: tas śirds ti hru ms ; trūkums: tur irr tru hku ms un bads; bet vārds plikums lietots ar nozīmi 'nabadzība' (ME III 345, die Armut): Kas muhf śchkirs no Kriftus mihleśtibas - voi debbef, jeb bailiba jeb vaijaśchana, jeb badds, jeb plikkums, jeb likśta, jeb fohbins? Mūsdienās neierasts ir vārds nopelnums 'nopelns, alga', kas spredikī lietots vairākas reizes: un wingna dahrga no p el numa pee kruśta; tas grehku nopelnums irr ta nahwe; ar Kriftus dahrgu un śwehtu no pel n u mu . Vārds nopelnums, spriežot pēc vārdlietojuma periodikā, izplatīts 19. gs. un retu reizi 20. gs. sākumā.

Vairāki darītāju apzīmējumi, kas darināti no verbiem, atvasināti ar piedēklịiem -ējs, -tājs - dzēerejs 'dzērājs': nedf df eh reji [..] to Deewa walftibu neredfehs; pārkāpējs: nedf laulibas pahrkah peji [..] to Deewa walftibu neredfehs; sèjējs: Śchè tas leelais ś e h jejs [...] neapnizzis śtrahda; laupītājs: nedf la u pitaji [..] to Deewa walftibu neredfehs.

Personu apzīmējumi darināti arī ar piedēkli -nieks - grēcinieks: jo mehs grehzineeki wiśśi lihdf; ienaidnieks: kas irr Kriftus e en ai dneeki; maucinieks 'staigulis, netiklis', mīkstnieks 'g̣̦ēvulis, raudulis': nedf ma uzin e eki, [..] nedf mihkftneeki [..] to Deewa walftibu neredfehs; pretinieks: woi kas śawu dwehśeli prettin eek a m nodewuśchi.

Visai bieži Klota sprediķī atrodami arī atvasinājumi ar -(e)kl-. Tie ir gan mūsdienu valodā tādā pašā nozīmē lietoti lietvārdi - loceklis: lihdf pahrśchkirśchanai tahs dwehśeles un ta garra, to lo h zeklu un to śmadfenu; māceklis: tee mahzekli un Apuśtuli; gan vārdi ar nedaudz atškisīiou nozīmi - dieveklis 
'elks': Kur irr ta śirds, ne kas kalpo wehl dafcheem d e ew ekl e em, ko pee śewim turr?; spīdeklis 'apgaismojums': lai tohs darram par muhśu kahju śpi h d ekli. Divi lietvārdi mūsdienu valodā vispār netiek lietoti - laceklis 'zaimotājs; apmelotājs': nedf la z zekli [..] to Deewa walftibu neredfehs; traipeklis 'traips': kurrai nebuhtu ne kahds tra i p ek li s, nedf grumba, nedf zitta kahda waine; kas bef traipekla un bef grumbas.

Savā spredik̄̄i Klots labprāt lietojis arī deminutīvus, kas darināti atbilstoši tradicionālajam rakstu valodas modelim ar piedēkḷiem -ing- un - $\bar{l} t-$, piemēram, kà mahte darra ar śawu nemeerigu beh rningu; taws behrninfch naw wifs nomirris; eekśch wingna śchehlaśtibas ga ifm iñas; śchi irr ta ga ifm iña kas winnnam śpihd; no śchi śinnepa graudinga; kas ufnehmufchi to dfihwibas g rau d in u; kas ścho śt un di inu eekśch tawas śirds kriht; ko tee warretu śakraht kuh liśchôs; śpihd kà rihta śa u lite pehz nakts; ta dfihwibas śa ulite arri śchè irr atśpihdejuśi.

\subsubsection{Adjektīvi}

Adjektīvu sprediḳ̄i ir samērā maz, tie ir primāri vārdi, kā akls, ass, ašs, bagāts, ciets, dārgs, dzīus, kūtris, labs, liels, mīksts, mīlšs, nikns, pilns, salds, stiprs, svešs, svèts, tukšs, tumšs, vecs, vesels, piemēram, lai tas nebuhtu wairs ze et bet paliktu par mi hkśt u un augligu femmi; Tee irr tee śwe h ti Deewa wahrdi; woi naw welti śluddinati un neatgreefiśees $t u k f c h i$; kā arī atvasināti vārdi, galvenokārt ar izskaņu -īgs: auglīgs, bezvainīgs, cienīgs, derīgs, dusmīgs, griezìgs, iznīcīgs, kristīgs, mierīgs, mūž̀̆gs, neauglīgs, necienīgs, neiznīcīgs, nemierīgs, pilnīgs, spēcīgs, vienīgs, viltīgs, žēlìgs, piemēram, paliktu par mihkśtu un a ugligu femmi; no śawas mu hfchigas aizinaśchanas; kà mahte darra ar śawu ne me e rig u behrniņu. Starp atvasinājumiem ar -īgs ir atvasinājums brīn-išķigs: Ak teeścham un pateeśi b ri h n iśch kig s irr tas atdfemdinaśchanas śpehks; saliktenis trīsvienīgs: kas zittam kungam kalpo, ne kà tam trihfweeniga m Deewam. Ir daži atvasinājumi ar -ens - istens: weena i $h$ śte n a Kriftus-bruhte; pee ta i h śt en a Deewa-darba; ar -āds: visāds, un -ējs: abējs.

Adjektīvam ass ir paralēli varianti - ass un ašs: śwehti tavus aśśus wahrdus pee mums; ścho neaugligu femi winfch ufplehśch ar to a śch u arkli śawas bauślibas. Vārds ašs ar nozīmi 'ass' reǵistrēts arī ME I 147.

Vairākas reizes tekstā lietotas adjektīvu pārākās pakāpes formas: $a$ ś $s$ aks ne ka kahds abbejâ pusśsê greefigs fohbins; weena deena eekśch taweem pagalmeem [..] irr la bbak a ne ka tuhkśtośchas zittas.

Atsevišksos gadījumos spredik̄i lietots adjektīvs ar noteikto galotni - vīriešu dzimtes vsk. nom./vok.: Bet tu ak śweh ta is Deews śwehti muhf; Tee irr tee wahrdi, ko tas wiśśuśpehzigais śwehtais un fchehligais Deews [..] 
uf teem tehweem irr runnajis; irr ufaudfis tas le el a is kohks tahs kriftigas draudfes; dsk. nom./vok.: ak, mi hle e, bet citos locijumos - nenoteiktā galotne: ścho nea ugligu femi; tahs kriftigas draudfes. Nenoteiktā galotne reizēm lietota arī vokatīvā: Mihḷ i tizzibas beedri!

\subsubsection{Pronomeni}

Personu pronomeni R. Klota sprediķ̄i ir tie paši kā mūsdienu valodā. $E s, t u$, kā arī atgriezeniskais sevis ar prepozīcijām lietoti vecā instrumentāla formā: Un kad juhs ar man [n] i m ar śirds behdahm redfehjufchi śchinnîs gaddôs; arri tu eśśi kohpts un pe e tewi m irr śtrahdahts ka waijaga; Kur irr ta śirds, ne kas kalpo wehl dafcheem deewekleem, ko pee ś ew i m turr? Savukārt akuzatīvā lietotas bezgalotnes formas tev, sev: Eij prohm, ef tew nekad ne-efmu pafinnis; Tad lai pahrraudfamees s ew paśchus kahdi mehs eśśam. 3. pers. pronomeni viņš, vinga lietoti arī norādāmā pronomena tas, tā nozīmē: Arri tu eśśi kohpta no ścheem Deewa-wahrdeem, -- woi tu eśśi mannijuśi wi ñņu atdfemdinaśchanas śpehku?; tad tu gan redfeśi kahds dfihwibas kohks ufaugs ka tu no wi ņņ a lappahm warreśi dfihwoht muhfchigi.

Norādāmie pronomeni ir līdzīgi mūsdienu valodai, lokatīvā lietotas tikai formas šinī, tanī, šinīs: Juhs śchodeen śchè śchurp eśśat śaaizinati śch in n î śawâ Deewa-nammâ; tad eekriht ta n nî śirdî kà labb-śataiśihtâ fem̄ê; Bet śc hi in nîs leetâs mehs ufwahram daudf zaur to, kas muhs ir mihlejis.

Pronomens tas bieži lietots arī vācu valodas noteiktā artikula funkcijā: Ta fchehlastiba muhśu Kunga Jefus Kriśtus, ta mihlestiba Deewa ta Tehwa un ta śadraudfeśchana ta Śwehta Garra lai irr ar mums wiśśeem; un tas grehku nopelnums irr ta nahwe.

\subsubsection{Verbi}

Verbu lietojums R. Klota sprediķī atbilst 18. un 19. gs. rakstu valodai. İstenības izteiksmē lietota galvenokārt verba vienkāršā un saliktā tagadne, vienkāršā un saliktā nākotne.

Tagadnes dsk. 1. pers. verbi parasti ir ar galotni -am: eśśam, gullam, nefinnam, śauzam, śnaudam, ufwahram 'uzvaram', waidam.

Tagadnes 3. pers. refleksīvo verbu formas, neatkarīgi no verba celma, lietotas ar garo patskani /ā/ galotnē: darbojahs, dfenahs, ifplattahs, neturahs, raugahs. Šāda īpatnība „raksturīga latviešu rakstu valodai, sākot ar visvecākajiem 16. gs. tekstiem, sarunvalodā un izloksnēs tā sastopama līdz pat mūsdienām“" (Pokrotniece 1991: 209-210).

Pāris gadījumos verba pagātnes galotne ir -e: neśśe muhśu śehrgas; te pagātnes 3. pers. nese varētu būt dialekta forma, sens $\bar{e}$-celms (Endzelīns 
1951: 679), bet ciešamās kārtas palīgverba tikt pagātnes forma tike ir jaunināta, iespējams, viduslejasvācu valodas ietekmē (Blese 1929: 29): tas bauślibas arklis tik ke peelikts to ufplehśt. Šādas verbu pagātnes formas ar $<\mathrm{e}>$ galotnē līdz 19. gadsimta vidum bija izplatītas daudz biežāk (sal. Vanags 2015: 53). Sprediḳī ir daži verbi, kuru tagadnes celma forma atšķiras no mūsdienās lietotās:

atrasties - atronas: ka wiśśur arri wehl at ro hn a h s tahdu, kas irr Kriśtus eenaidneeki, lietots kā tagadnes no-celma verbs (ELVG: 750);

iepriecināt - tagadnes 3. pers. ir iepriecinā kā dạ̦ā vidus izlokšņu (Rudzīte 1964: 134): kas muhs e epreezina h wiśśâs muhśu behdâs;

snaust - vidus izlokšņu forma tagadnes dsk. 3. pers. ir snaudam (Rudzīte 1964: 134): Mehs gullam un śnaudam .

Atšķirīga celma forma varētu būt arī tagadnes 3. pers. forma ar galotni -a: apdrauda: Ka tee Deewa-wahrdi muhs ap d ra u da weenumehr śazzidami.

Vēlējuma izteiksmē visās atrodamās vsk. un dsk. personās lietots formants -tu resp. -tos: un ja tu śchodeen wehl ta gribbetu darriht; lai tas nebuhtu wairs zeets, bet paliktu par mihkśtu un augligu femmi; ka tad a trafto hs pilnas wahrpes, ko tee war retu śakraht kuhliśchôs; lai zilweku dwehśeles at dfi i w wo to hs un peedfim tu no jauna; ja tahds śchodeen śchurp buhtu atnahzis, tam ef gribbu ufśaukt; ja tas Kungs nebuhtu bijis ar śaweem wahrdeem.

Atstāstījuma izteiksme lietota gan vienk. tagadnē, gan nākotnē: No śchi Deewa wahrda śakka muhśu textis, ka tas eśśoht dfihws; Deewa wahrdi, kas śakka, ka ta notikśchoht uf preekśchu.

Vajadzības izteikšanai sprediḳi visai bieži ir lietota konstrukcija ar dat. + jā-: Kapehz mums nu irr ja-a ifk a weh śawu deenas-darbu?; nahk tas laiks, kad ikkatram jaśa kka, kà Iabs śazzija uf Zowaru; woi no ta mums śchodeen naw ja-le ezina preekśch Deewa un zilwekeem; mums arween no jauna pee winnna zellleem jakriht un ja-fakka; tev bija ja-śakka. Vairrākkārt vajadzība ir izteikta ar konstrukciju büt + nenoteiksme - gan citātos no Bībeles: ka tam ne buhf tukścham pee winnna atgreeśtees, bet darriht, ka wingnam patihk, - un ka tam buhf ifdohtees, uf ko tas tohp fuhtihts; wiśśeem buhf eeeet Deewa walftibâ zaur daudf zeefchanam; gan autora paša tekstā: jo jums buhf pilnigeem buht. Reizēm vajadzība ir izteikta leksiski ar verbu vajadzêt: woi ta Deewa-kalpośchana pee mums noteek kà wai jaga; arri tu eśśi kohpts un pee tewim irr śtrahdahts ka wa ijag a; eepreezinaśchanas mums teeścham wai jaga śchinnî behdu-muhfchâ; tad mums nepeetruhks, kas mums waijaga.

Pavēles izteiksmes vsk. 2. pers. forma sakrīt ar īstenības izteiksmi: Bet tu ak śwehtais Deews, śwehti muhf eekśch tawas pateeśibas. Dsk. 2. pers. 
lietotas formas ar galotni -ait, t. i., -ajt vai -aijt (par to Endzelīns 1951: 888): dfennajtees pehz śwehtiśchanas; Śakaijt jelle - t. b.,- woi tad eśśam mehf [..] śwehta garra pilni. Dsk. 1. pers. pamudinājums izteikts ar nākotnes formu: A pzer reśi im tad pehz ścheem wahrdeem, ko nupatt klauśfijufchees [..] un jautaśimees; śo hliśi m winnam śchodeen atkal; un lu hgśi mees beidfoht; vai arī ar tagadnes formu un partikulu lai: Tad la i pahr raudfa mees sew paśchus kahdi mehs eśśam, un lai praśśamees, woi mehs eśśam tahda draudfe; Tadehl lai wiśśi pateiza m śawam Deewam. Reizēm imperatīva formu pastiprina partikula jele: ne dohma jelle aifbildinatees. Imperatīva dsk. 1. pers. forma lai pahr raudfamees veidota no verba nenoteiksmes saknes - pārraudzìties.

Verba divdabju formas sprediḳ̂̄ ir lietotas visai bieži, trūkst tikai darāmās kārtas tagadnes divdabju ar izskaņām -ošs, -oša un nelokāmo divdabju ar -am, $-\bar{a} m$.

Darāmās kārtas pagātnes divdabji ar -is, -usi, -ies, -usies veido verbu saliktos laikus, reizēm izlaižot palīgverba tagadnes formu ir: Arrī mehs eśś a m gruhtus gaddus peedfihwojuśchi; Es to Kungu eśmu redfejis un manna dwehsele irr meerig tap puśi; zik reif tu apbehdinahts śazzijis śawâ śirdî: Kur es maifi ñemśchu; bet mehs, kas mahzijuśchees śazziht ar kehninu Dahwidu. Šis divdabis lietots arī kā sekundārais predikatīvais komponents: śchè tas leelais śehjejs, kas rihta agrumâ zehlees, ne ap nizzis śtrahda; un kā apzīmētājs: Tas Gars ta debbeśîs ufbraukuśch a Kunga.

Kā vēl 19. gs. pirmajā pusē parasts (Rosenberger 1830: 60-61), šo divdabju vīr. dz. dsk. forma no atgriezeniskajiem verbiem lietota arī sieviešu dzimtes nozīmē: [..] bet arri wiśśu to le et u dehl, kas zaur grehkeem zehluśchees; zik tad no jums apbehdinatahm mahtehm irr atfpirguśchees pee teem wahrdeem ta Kunga.

Ciešamās kārtas pagātnes divdabji ar -ts, -ta lietoti ciešamās kārtas laika formu veidošanā: vienkāršie laiki parasti ar tapt: woi behrni to hp audfehti eekśch ta Kunga Jefus atfihśchanas un pamahziśchanas; śche tas sirds tihrums to hp arts un ezzehts; tad juhs fihdiśeet un tapfeet klehpî $n$ eś $t$; ; vienu reizi arī ar tikt: Arri pee tawas śirds zittkahrt tas bauślibas arklis tikke peelikts to ufplehśt; saliktie laiki - ar būt, kas var būt arī izlaists: Juhs śchodeen śchè eśśat fa aizinati; bet kadehl śchi leeta naw nolikta uf kahdu śwehdeenu?; zaur kurro bruhzehm mehf eśśam dfeedinati; bet śchi deena mums nolikta no bafnizas-waldiśchanas preekśchneekeem. Šis divdabis lietots arī kā sekundāri predikatīvais komponents: woi mehf ap k a u n et $i$ no Jefu leelas mihleftibas, winnnam ikdeenas pee kahjahm krihtam; un kā apzīmētājs: Kas mums ufkriht kà kahds śtipri a pbrungohts wihrs; 
zik tad no jums apbehdinatahm mahtehm irr atfpirguśchees pee teem wahrdeem ta Kunga.

Ciešamās kārtas tagadnes divdabis ar -ams konstatēts tikai vienu reizi: daudf Raëles muhśu śtarpâ apraudaja śawus behrnus - un negribbejahs eepreezinajamas.

Divdabis ar -dams lietots kā mūsdienās saistījumā ar verbu, bet ne par substantīva apzīmētāju: ta wingśch li h gśmodamees dfeed; arī veidojot divdabja teicienu: ja winfch, at fi h da m s fawu grehku-buhfchanu [..] śawâs śirds bailês kleeds ar Pahwilu; zittu śweśchu tizzibu kahroja-zer reda mi paśaules labumus; Woi eśśam mehs atśazzijuśchi pa wiśśam tai paśśaulei un wiņñas kahribahm, ka Jefus Kriśtus darrija - eekśch win̨nga pehdahm mihdami?

Divdabis ar -ot arī lietots dažas reizes: Kur irr kam ne-muhfcham aśśaras ne buhtu jabirrina ścho muhfchas zellu ś ta iga jo ht ; śohliśim wingñam śchodeen atkal [..] un luhgśimees beidfoht ta; divreiz tekstā atrodams arī tā laika rakstu valodā sastopamais, taču nevēlamais (Endzelīns, Mīlenbahs 1907: 148) neizsakot 'neizsakāmi': par weenu neifśa ko ht leelu un śpehzigu eepreezinaśchanu; Ka winfch zaur śawu befwainibu un nenofeedfibu, un ne ifśa ko ht leelu mihleśtibu mums [..] muhśu waines ufrahda.

Analizētajā R. Klota sprediḳī atrodami arī atsevišḳi verbi, kas mūsdienās vairs netiek lietoti, mainījušās nozīmes, atškiras saknes vai piedēkḷ̆a forma: aloties 'kḷūīities' (ME I 69): Kas neallojahs dafchkahrt wehl; tagad plašāk pazīstams no R. Blaumaņa daiḷrades;

audzēt 'audzināt' lietots tāpat kā latviešu folklorā arī attiecībā uz cilvēkiem, ne tikai uz augiem vai dzīvniekiem (ME I 215, 216): woi behrni tohp a udfe hti eekśch ta Kunga Jefus atfihśchanas un pamahziśchanas;

birināt 'birdināt' reg̣istrēts Zasā un Langes vārdnīcā (ME I 298): kam ne-muhfcham aśśaras ne buhtu ja-birrina;

darīt 'radīt': zaur to wahrdu śawas muttes debbes un femmi ir darrijis, bet turpat arī darīt veselus: muhs weśśelus darriht; darìt dzīous kā mūsdienās: tas wahrds, kas dfihwus darra; vai arī ar nozīmi 'veikt, rīkoties': bet da rrriht, kas wiņnam patihk;

dzisināt 'dzesēt, atvieglot': Tas naw wiśs tas wihns un elje, kas muhśu śahpes dfiśśina (ME II 566, dzisināt 'atvēsināt');

dzīties 'tiekties': woi wiśśa śchi draudfe arri dfe n n a h s, tahda draudfe palikt ikdeenas jo wairak; kà tee ufśkubbina dfi h te e s pehz teem Garra augleem; izdot 'dot': la i ifdohd baggatus auglus (ME I 730, izduôt 2) izvirzīties no iekšpuses, laut lai aug), mūsdienās šajā nozīmē parasti saka: dod - lai dod bagātus auģıs; 
palikt 'kḷūt': pa likt u par mihkśtu un augligu femmi. Tomēr arī mūsdienu valodā verbu palikt lieto saitiņas kḷ̂ut nozīmē, kaut arī literārās valodas norma to neiesaka;

pārvērtīt 'pārvērst' (ME III 187 - no Glika Bībeles tulkojuma): un augam ikdeenas un pilnīgi tohpam un tohpam pahrwehrtiti eekśch Kriśtus Jefus gihmi;

uzvārēt 'uzvarēt' (ME IV 397): Bet śchinnîs leetâs mehs ufwa h ra m daudf zaur to, kas muhs ir mihlejis.

Refleksīvo verbu lietošanā Klota spredik̦ī vairākos gadījumos ir vērojamas atškirīības no mūsdienām:

jautāties 'jautāt': Jau taśi mees, woi tee arri pee śchihs draudfes tahdu śpehku irr parahdijuśchi;

pazusties 'pazust': negribb, ka mums buhs pafuśtees;

prasīties 'prasīt, jautāt': un lai praśśa mees, woi mehs eśśam tahda draudfe.

\subsubsection{Prepozīcijas}

Prepozīcijas un to pārvaldījums R. Klota sprediḳ̂̄ lielākoties atbilst mūsdienu latviešu valodas lietojumam. Atšksirības redzamas vairāku prepozīciju lietojumā: caur, iekš, no, priekš, uz, kas daḷēji var būt radušās vācu valodas ietekmē.

caur - norāda darbības veicinātāiju kā vācu valodā: Bet zaur ko tad tahds śwehts darbs tohp paftrahdahts?; Bet no śchihs grehku-nahwes tas Kungs muhf gribb ufmohdinaht zaur to balśi śawas muttes; Bet śchinnîs leetâs mehf ufwahram daudf zaur to, kas muhf ir mihlejis.

iekš - lietots lokatīva vietā: woi behrni tohp audfehti e ekśch ta Kunga Jefus atfihśchanas un pamahziśchanas; woi ikweens darbojahs eekśch tahm Deewa le e ta h m; śchośtundinu e ekśch tawas śirds kriht tà glabbaht.

no - var norādīt uz darbības veicēju ciešamās kārtas konstrukcijās: śchi deena mums nolikta no bafnizas-waldiśchanas preekśchneekeem; tee irr tee wahrdi, ko tee śwehti wihri irr ufrakśtijuśchi, dfihti no Śwehta Ga r ra; saistīta ar verbiem sacīt, zināt, liecināt pēc vācu valodas modeḷa (sagen, wissen, zeugen von): No śchi Deewa wahrda śakka muhśu textis; mehs nefinnam no Deewa, kahds winfch irr; woi no ta mums śchodeen naw ja-le ez in a preekśch Deewa un zilwekeem.

priekš - lietots adresāta nozīmē: Kur ef maifi ñemfchu preekśch tik da udfe e m; adverbiāli - lietvārda lokatīva priekšā nozīmē: woi no ta mums śchodeen naw ja-leezina preekśch Deewa un zilwekeem. 
$u z$ - var norādīt darbības nolūku, objektu, laiku: Śchè tohp muhśu dwehśele apkohpta, uf muhfchigu dfihwośchana [tā!]; Un uf ko winfch tohp śuhtihts, ja ne uf to, lai zilweku dwehśeles atdfihwotohs; tas wiśśuśpehzigais śwehtais un fchehligais Deews [..] uf teem tehweem irr runnajis; bet kadehl śchi leeta naw nolikta uf kahdu śwehdeenu?

\subsection{Sintakses īpatnības}

Tāpat kā daudzos 19. gs. sākuma un vidus tekstos, arī R. Klota sprediḳ̂̄ vācu valodas iespaidā nesaskaņotā apzīmētāja grupa bieži novietota aiz apzīmējamā vārda (par to Pokrotniece 1991: 217; Vanags 2013: 182): Ta fchehlastiba muhśu Kunga Jefus Kriśtus, ta mihlestiba Deewa ta Tehwa un ta śadraudfeśchana ta Śwehta Garra lai irr ar mums wiśśeem; Kahds tas śpehks to De ewa-wardu?; Ar ścho śaldu peenu śawas muhfchigas zerribas winfch muhfapkluśśina.

R. Klota sprediḳi nolieguma teikumos atšksirīgi no daudziem citiem sava laika avotiem, piemēram, F. V. Veiriha sprediķa (Paegle 2019: 140), konsekventi lietots divkāršais noliegums; kurrai nebuhtu ne-kahds traipeklis; un kam nekad nebu htu ja-nopuhśchahs ar gruhtahm nopuhśchanahm; tad mums nekad nepeetruhks, kas mums waijaga.

Dažas savdabības un svārstības redzamas locījumu lietojumā. Arhaiska, ja vien autentiska, ir ǵenitīva forma subjekta funkcijā, izsakot nenoteiktu daudzumu (Endzelīns 1951: 556): ka wiśśur arri wehl atrohnahs ta hdu, kas irr Kriśtus eenaidneeki.

Lìdzās verbam nebūt nolieguma teikumos parasti lietots nevis ǵenitīvs, bet nominatīvs: kurrai nebuhtu ne-kahds traip eklis; daudf Raëles muhśu śtarpâ apraudaja śawus behrnus - un negribbejahs eepreezinajamas, jo tee nebija wairs; kam naw nekahda waine.

Nominatīvs ğenitīva vietā atrodams arī līdzās verbam trūkt: Jo te e a u gḷ $i$ tam kohkam tru h kft un winnnu ja-nozehrt. Ar formu vajaga var būt saistīts gan genitīvs, gan nominatīvs: e epre ezin aśch a nas mums teeścham waijaga śchinnî behdu-muhfchâ; tad mums nepeetruhks, kas mums waijaga.

Savukārt aiz verba vajadzības izteiksmē tiek lietots substantīvs akuzatīvā: Jo tee augli tam kohkam truhkft un wiņņu ja-nozehrt; Kapehz mums nu irr ja-aifkaweh śawu deenas-darbu?

Ar apstākḷa vārdu daudz biedrojas ne tikai g̊enitīvs, bet arī citi locījumi: ta dfihwibas śaulite arri śchè irr atśpihdejuśi daudf śirdîs; uf daudf dweh ś ele h m gan drihkśt śazziht ar preeku; wiśśeem buhf eeeet Deewa walftibâ zaur daudf zeefchanam. 


\subsection{Interpunkcija}

Pieturzīmju lietošanā sprediķa tekstā nav sistēmas, vietumis komati ir likti iederīgi, bet daudzviet to trūkst:

Un [,] ja tu śchodeen wehl ta gribbetu darriht, un to paśchu graudinu, kas ścho śtundinu eekśch tawas śirds kriht [,] tà glabaht: tad tu gan redfehśi [,] kahds dfihwibas kohks no ta ufaugs [,] ka tu no winnna lapahm warreśi dfihwoht muhfchigi. (LVVA 1851: 200. 1p.-200. 1p. o. p.)

Grūtāk interpretējams ir gulošo svītrinu lietojums R. Klota rokrakstā. Tās var būt gan defises, gan domuzīmes, kaut to garuma ziņā konsekventas atškirīibas nav. Par defisi uzskatāma īsa svītriņa, ar ko Klots dažreiz atdala vārdu morfologisiskos elementus, piemēram, ja-nopuhfchahs, ne-ifśakkoht, ne-kahds, kā arī vieno vārdu savienojuma komponentus, kas apzīmē vienu ¡ēdzienu: bafnizas-waldiśchanas, behdu-muhfchâ, debbes-śchkuhnîs, deenasdarbu, Deewa-behrneem, Deewa-darba, Deewa-nammâ, Deewa-wahrdu, grehkubuhśchanu, Deewa-kalpośchana, Kriftus-bruhte, nakts-tumśibas, śaules-śiltumu, textes-wahrdi, telts-weetu, teeśas-deena $\mathrm{u}$. tml.

Savukārt par domuzīmi uzskatāmas tās gulošās svìtriņas, kas nevis atdala teikuma gramatiskās sastāvdaḷas, bet apzīmē oratora pauzi, lai runa būtu izteiksmīgāka. Labs piemērs tam ir raksta sākumā minētais Klota sprediķa fragments, kur domuzīme lietota kā pauzes apzīmētāja:

Mihli tizzibas beedri! Juhs śchodeen śchè śchurp eśśat śaaizinati śchinnî śawâ Deewa-nammâ. - Bet woi tad śchodeen kahda śwehdeena? - Woi tad śchee kahdi śwehtki? - Ne, m. t. b., ta gan naw. Bet śchi deena mums nolikta no bafnizas-waldiśchanas preekśchneekeem, pahrraudfiht ścho draudfi un apluhkoht, woi ta Deewa-kalpośchana pee mums noteek kà waijaga, - woi behrni tohp audfehti eekśch ta Kunga Jefus atfihśchanas un pamahziśchanas, - woi laulati draugi mihleśtibâ un śaderribâ dfihwo, - woi ikweens darbojahs eekśch tahm Deewa leetahm, un woi wiśśa śchi draudfe arri dfennahs, tahda draudfe palikt ikdeenas jo wairak, kurrai nebuhtu nekahds traipeklis, nedf grumba, nedf zitta kahda waine, bet kas buhtu śwehta un befwainiga,- weena ihśtena Kriftus-bruhte. (LVVA 1851: 198. 1p.)

\section{Nobeigums}

Mācītāja R. Klota 1851. gada rokraksts ir raksturīgs 19. gs. vidus teksts. Viņa vizitācijas spredikikis Mālpils draudzei ir emocionāli piesātināts ar romantisma iezīmēm. 
Teksta latviešu ortogrāfija, kā arī fonētika kopumā atbilst citiem 19. gs. vidus rakstiem. Trūkst konsekvences /s/, /š/ šksīrumā no /z/, /ž/, nav apzīmēti /ks/, /g̊g . Bieži pārsvītrojuma nav arī mīksto līdzskaņu /1̣,/, /ņ/ un /ṛ/ rakstībā. Ortogrāfijas jauninājums varētu būt vienkāršais $\langle\mathrm{v}\rangle$, kuru Klots lieto līdztekus tradicionālajam $<\mathrm{w}>$.

Rokraksta valodas morfolog̣ija un sintakse pamatos sakrīt ar sava laika rakstu valodas tradīciju. Spilgtas iezīmes: 1) substantīvu celmu atšķ̌irība; 2) bieži lietoti ar -šana, -ība, -ums atvasināti substantīvi; 3) raksturīgi ar -īgs atvasināti adjektīvi; 4) lietotas seniskas pronomenu formas manim, tevim, sevim; 5) sastopamas dažas dialektālas un arhaiskas verbu formas; 6) dažas savdabības un svārstības locịjumu lietošanā; 7) domuzīme daudzviet ir lietota oratora pauzes nozīmē.

Rakstītāja latviešu valodā atrodamas arī vairākas laikmetam raksturīgas vācu valodas pēdas: 1) artikulu nozīmē lietotie vārdi tas, viens; 2) prepozīcijas caur, iekš, no, priekš, uz lietotas arī vācu valodai raksturīgās nozīmēs; 3) nesaskaņotās apzīmētāja grupas bieži novietotas aiz apzīmējamā vārda.

\section{Avoti}

LVVA $1851=$

Latvijas Valsts vēstures arhīvs. Vidzemes evaņgēeliski luteriskā konsistorija. Konsistoriālā iecirkṇa vizitāciju protokoli. 233. fonds, 3. apraksts, 3010. lieta, 198.-202. lp.

\section{Literatūra}

BV $1871=$

Baerent, Paul. 1977.

Bergmane, Anna. Blinkena, Aina. 1986.

Blese, Ernests. 1929.

$\mathrm{DBL}=$

DI $1842=$

DI $1857=$

$\mathrm{EH}=$

Endzelīns, Jānis. 1951.

Endzelīns, Jānis,

Kārlis Mīlenbahs. 1907.
Dažādas ziṇas (no iekšzemes). Baltijas Vēstnesis, Nr. 52 (29.12.1871.).

Die evangelischen Prediger Livlands bis 1918. Köln, Wien: Böhlau.

Latviešu rakstības attīstība. Latviešu literārās valodas vēstures pētījumi. Rīga: Zinātne.

Latviešu personu vārdu un uzvārdu studijas. I. Vecākie personu vārdi un uzvārdi (XIII-XVI g. s.). Ar īsu satura un svarīgāko slēdzienu kopsavilkumu vācu valodā. Izdots ar kultūras fonda pabalstu. Rīga: A. Gulbis.

Deutschbaltisches Biographisches Lexikon 1710-1960.

Personalnotizen. Das Inland, Nr. 10 (10.03.1842.).

Korrespondenz. Das Inland, Nr. 30 (29.07.1857.).

J. Endzelīns un E. Hauzenberga. Papildinājumi un labojumi K. Mīlenbaha Latviešu valodas vārdnīcai. I-II. Rīga, 1934-1946. Latviešu valodas gramatika. Rīga: Latvijas Valsts izdevniecība. Latweeśchu gramatika. Rigâ: K. J. Sichmaņa apgahdibâ. 
KV $1911=$

KV $1921=$

Klekere-Krekele, Ināra. 2011.

\section{LA $1864=$}

LFV II =

$\mathrm{ME}=$

MV $1863=$

MV $1872=$

Paegle, Dzintra. 2019.

Pauloviča, Ieva. 2011.

Plāķis, Juris. 1936.

Pokrotniece, Kornēlija. 1991.

\section{RK $1870=$ \\ RK $1876=$}

RZ $1876=$

Rinkužs, Kārlis. 1938.

Rosenberger, [Otto]. 1830.

Rudzīte, Marta. 1964.

Seniespiedumi. 1999.

Švābe, Arveds. 1958.

TLD $1842=$

Vanags, Pēteris. 2013.
Konversacijas vārdnīca. Trešais sējums. Rīga: R.L.B. Derīgu Grāmatu nodaḷa.

Konversacijas vārdnīca. Ceturtais sējums. Rīga: R.L.B. Derīgu Grāmatu nodaḷa.

Latviešu dzejas publikācijas un vienotas literārās telpas veidošanās 1789-1855. Promocijas darbs bibliotēku zinātnes apakšnozarē. Darba zin. vad. Dr. philol. Viesturs Zanders. Rīga.

Dīnsberg. Vidzemes skolmeisteru=skolas un skolas kunga Cimzes goda diena. Latviešu Avizzes, Nr. 34 (20.08.1864.).

Laua, Alise, Aija Ezeriņa, Silvija Veinberga. Latviešu frazeologiijas vārdnīca divos sējumos. II. N-Ž. Rīga: Avots, 1996.

K. Mīlenbaha Latviešu valodas vārdnīca. Redig̣ejejis, papildinājis, turpinājis J. Endzelīns. I-IV. Rīga: Kultūras fonds,1923-1932. Ebgr. Vidzemes skolmeisteru saiešana Turaidē 1863. gadā. Mājas Viesis, Nr. 24 (08.07.1863.).

J. Kakting. „Dziesmu rota jaunekḷiem un vīriem“ I, II. Mājas Viesis, Nr. 12 (18.03.1872.).

Ērgḷu un Ogresmuižas luterāṇu mācītāja Fridriha Vilhelma Veiriha 1850. gada sprediķis latviešu valodā. Baltu filoloǵija XXVIII (2), 123-142.

Mālpils Dievmātes Patvēruma Pareizticīgo draudze 19. gs. Mālpils Vēstis. Nr. 1 (117), 2 (118).

Latvijas vietu vārdi un latviešu pavārdi. I daḷa. Kurzemes vārdi profesora J. Plāķa sakrāti un sakārtoti. LŪR Filolog̣ijas un filozofijas fakultāte. Sērija IV sējums. 1. Rīga: LU.

J. Lange un „Latviešu Ārste“. P. E. Vilde. Latviešu Ārste jeb ìsa mācība no tām Vājībām un no šās Zemes Zālēm, ar kuṛām Cilvēkus un Lopus var ārstēt un izzālotot. Jākoba Langes 1768. gada tulkojuma teksts. Rīga: Zvaigzne, 199-218.

Veränderungen. Rigasches Kirchenblatt. Nr. 52 (28.08.1870.).

Aus den Kirchenbüchern. Rigasches Kirchenblatt. Nr. 13 (26.03.1876.).

Inland. Riga 23. Oktober. Rigasche Zeitung, Nr. 247 (23.10.1876.). Jānis Cimze. Rīga: Valters un Rapa.

Formenlehre der lettischen Sprache. Conspect für seine Zuhörer. Mitau: Joh. Friedr. Steffenhagen und Sohn.

Latviešu dialektolog̣ija. Rīga: Latvijas Valsts izdevniecība.

Seniespiedumi latviešu valodā. 1525-1855. Kopkatalogs. Izstrādājis autoru kolektīvs Silvijas Šiško vadībā. Zinātniskais redaktors Aleksejs Apīnis. Rīga: Latvijas Nacionālā bibliotēka.

Latvijas vēsture 1800-1914. Stokholma: Daugava.

Jaunas ziņas. Iz Rīgas. Tas Latviešu Draugs, Nr. 10 (05.03.1842.).

Latviešu literārās valodas attīstība. Latvieši un Latvija. I sējums. Latvieši. Atbildīgie redaktori: Ilga Jansone, Andrejs Vasks. Rīga: Latvijas Zinātṇu akadēmija, 177-203. 
Vanags, Pēteris. 2015.

Vičs, Andrejs. 1928.

Zelče, Vita. 2009.

Zemzare, Daina. 2011 [1961].

Dzintra Paegle

Baltu valodniecības katedra

Humanitāro zinātñu fakultāte

Latvijas Universitāte

Visvalža iela 4a, Rīga, Latvija

dzintrap@latnet.lv

Pèteris Vanags

Baltu valodniecības katedra

Humanitāro zinātnu fakultāte

Latvijas Universitäte

Visvalža iela 4a, Rīga, Latvija

pvanags@latnet.lv
Valoda „Stāstos”. F. B. Blaufūss. Vidzemes Stāsti. Stāsti no tās vecas un jaunas būšanas to Vidzemes laužu, uzrakstīti 1753. Rīga: Vēstures izpētes un popularizēšanas biedrība.

Latviešu skolu vēsture. Trešā grāmata. Vidzeme no 1800.1855. gadam. Rīga: R.L.B. Derīgu grāmatu nodạ̣a.

Latviešu avīžniecība. Laikraksti savā laikmetā un sabiedrībā.1822-1865. Rīga: Zinātne.

Kāds XVIII gs. krievu-vācu-latviešu-igauṇu salīdzināmās vārdnīcas manuskripts. Leksikologijas un leksikogrāfijas jautājumi. LPSR ZA Valodas un literatūras institūta Raksti, 13. laid. Rīga: ZA izdevniecība, 301-319. [= Daina Zemzare. Darbu izlase. Sast. un zin. red. Ilga Jansone. Rīga: LU Latviešu valodas institūts. 346-363.]

\section{SUMMARY}

\section{An 1851 Sermon in Latvian by Otto Robert von Klot (1808-1876), Lutheran Pastor at Mālpils}

\section{Dzintra PAEGLE, Pēteris VANAGS}

The article analyses the sermon by the Lutheran pastor Otto Robert von Klot (LVVA 1851), which was read during a church visitation to the Latvian congregation on October 11, 1851 at Mālpils Evangelical Lutheran Church in the Riga District. The article discusses and clarifies the pastor's biography, considers the content and expression of the handwritten sermon, the peculiarities of the use of orthography, morphology of nouns, adjectives and verbs, as well as some peculiarities of syntax and punctuation.

The manuscript of Pastor Klot is a typical mid-19th century text. His sermon is emotionally saturated with features of romanticism.

The Latvian orthography of the manuscript, as well as the phonetics in general correspond to other mid-19th century texts. There is a lack of consistency in the separation of consonants $/ \mathrm{s} /, / \check{\mathrm{s}} /$ from $/ \mathrm{z} /, / \check{\mathrm{z}} /$. Palatalization of the consonants $/ \mathrm{k} /, / \mathrm{g} /$ is never marked. 
Often there are no diacritics to denote the palatal consonants $/ 1 /, / \mathrm{n} /$ and $/ \mathrm{r} /$. An orthographic innovation could be the simple $<\mathrm{v}>$ that Klot uses alongside the traditional $<\mathrm{w}>$.

The morphology and syntax of the manuscript basically coincides with the written language tradition of its time. Some specific features: 1) variation of noun stems; 2) often-used derived nouns with suffixes -šana, -ība, -ums; 3) derived adjectives with suffix -īgs; 4) archaic pronoun forms manim, tevim, sevim; 5) several dialectical and archaic forms of verbs; 6) some peculiarities and variations of case forms; 7) a dash is used in many instances in the sense of a speaker's pause.

The Latvian language of the manuscript has several traces of the influence of the German language typical of the time: 1) the pronouns tas, $t \bar{a}$ and numerals viens, viena are often used in the meaning of the definite or indefinite article; 2) the prepositions caur, iekš, no, priekš, $u z$ are often used in the meanings typical to the German language; 3) attributive groups in the genitive are often placed after the head word. 


\title{
KRIKŠČIONIŠKOS KILMĖS ASMENVARDŽIAI LIETUVOJE SENIAUSIOJE 1599-1621 M. JONIŠKIO PARAPIJOS KRIKŠTO METRIKŲ KNYGOJE
}

\author{
Alma RAGAUSKAITÉ \\ Lietuviu kalbos institutas
}

\section{Ivadas}

Joniškio parapijos istoriniai antroponimai kilmès aspektu jau pradèti tirti. Ypač svarbus šios parapijos seniausios 1599-1621 m. krikšto metrikų knygos tyrimų kontekstas. Pirmiausia buvo pateikta būdingesnių aptariamos knygos tekstų pavyzdžių (ịvairių krikšto įrašų formulių), kuriuose užfiksuota lietuviškos kilmès vyrų asmenvardžių (Garliauskas 1998: 152-153; 2004: 22-24). Išnagrinejjus to paties bažnytinio šaltinio 186 Joniškio miesto gyventoju antroponimus, paaiškejjo, jog tarp krikščioniškos kilmės asmenvardžių daugiausia atsiradusiu iš trumpųiu krikšto vardų lyčių. Palyginus Joniškio ir parapijos kaimų vardynus, pastebèta, kad miestiečiu antroponimai kilmès požiūriu skiriasi nuo valstiečių. Pastarųjų vardyne buvo dažnesni lietuvių senieji dvikamieniai asmenvardžiai (Ragauskaite 2004: 16-17). Išanalizavus kalbamosios parapijos kaimų gyventojų dvinarius įvardijimus, nustatyta, jog 187 antrieji antroponimai yra lietuviškos kilmès. Iš aptartų 187 lietuviškos kilmès asmenvardžių buvo rekonstruota 112 skirtingų antroponimų lyčių. Tarp jų lietuvių senųjų dvikamienių asmenvardžių - 36 (32\% visų atkurtų), dvikamienių antroponimų trumpinių bei jų priesaginių vedinių - 19 (17\%), pravardinès kilmès asmenvardžiu - 57 (51\%). Sugretinus 112 atkurtų antroponimų formų su dabartinemis lietuvių pavardèmis, prieita prie išvados, jog $46(41 \%)$ funkcionuoja ir šiandien. Didesnè dalis, t. y. 62 (55\% visu rekonstruotu), turi tos pačios kilmès, tik skirtingos darybos atitikmenis tarp dabartinių pavardžių. Likusiųų 4 (4 \%) nėra šių dienų vardyne (Ragauskaitė 2019a: 162). Atkreipus demesị i XVI a. pabaigos - XVII a. pradžios Joniškio parapijos vyrų antroponimų etimologinius ypatumus, tolesnis kaimų gyventojų istorinès antroponimijos tyrimas yra svarbus ir tęstinas.

Antroponimine medžiaga straipsniui surinkta iš senosios 1599-1621 m. Joniškio parapijos krikšto metrikų knygos. Šio bažnytinio šaltinio pavadinimas pateiktas lotynų kalba „Liber Baptisatoru(m) ${ }^{1} \|$ Ecc(lesi)æ Parochialis Jani= ||scensis ab Anno 1599. - || usq(ue) ad An(n)um || 1621. -“. Priešlapyje

1 Rankraštyje užfiksuotos abreviatūros pildytos. Prierašas nurodytas skliaustuose. 
nurodyta dar viena lotyniška antraštė „CATA: || LOGVS. || BAPTISATO: \| RVM. EC: || CLESIÆ. || IANI: || SCEN: || SIS“. Aptariama rankraštinė knyga rašyta lotynų ir lenkų kalbomis (Garliauskas 1998: 139; 2004: 21-22; Ragauskaite 1999: 155; 2005: 66-67; 2015: 74; 2019a: 154). Palyginus braižą matyti, kad šią knygą raše bent keli asmenys. Nè vienas iš jų neįrašè savo pavardès. Krikšto registracijos formulès buvo įvairios (ilgesnès ir trumpesnės). Keliolikoje lapų nerašomi oikonimai, dalyje knygos įrašų tekstas buvo trumpinamas (rašomi tik asmenų vardai, nerašomi antrieji ar tretieji įvardijimo nariai). Kai kuriais atvejais nurodytas Šiaulių valsčiaus (nuo 1616 m. faktiškai veikusios Šiaulių ekonomijos) vaitas, kurio vaitystëje yra kaimas (Žilys 2012: 127).

Šio straipsnio tikslas - apibūdinti 1599-1621 m. Joniškio parapijos kaimų gyventojų užrašymo situaciją, išsamiai aptarti atrinktus 556 krikščioniškos kilmès asmenvardžius (antruosius dvinario įvardijimo modelio narius) darybos aspektu.

Šio straipsnio uždaviniai: 1) trumpai aptarti vardus (pirmuosius dvinarių ịvardijimų narius); 2) nurodyti produktyviausias antrųjų asmenvardžių priesagas; 3) rekonstruoti antroponimų formas, kurios šaltinyje turi užfiksuotus lietuviškus darybos formantus, ir palyginti jas su dabartinėmis lietuvių pavardèmis; 4) nustatyti, kurie analizuojami istoriniai asmenvardžiai nebefunkcionuoja dabartiniame vardyne.

Aptariant XVI a. pabaigos - XVII a. pradžios Joniškio parapijos istorinès antroponimijos duomenis, taikomi šie pagrindiniai tyrimo metodai: aprašomasis ir lyginamasis (Ragauskaitė 2005: 31; 2019b: 179). Reikès nustatyti dažniausias asmenvardžiu priesagas, apibūdinti patronimų ir nepatroniminès kilmès antroponimų grupių kiekybinį santykį.

\section{Asmenų vardai}

Svarbu aiškiai apibrèžti, kurie bažnytiniame šaltinyje užrašyti antroponimai priskirtini Joniškio parapijos kaimų gyventojams (Ragauskaitė 2019a: 155). Jų asmenvardžius atskirti padeda kaimų nuorodos lotynų ir lenkų kalbomis, pvz.: 1617 Matis Bohdanajtis <...> de villa Darginy JNŠ 1982; 1601 Pagi S3łostikiow <...> Martini Czepaitis JNŠ 22v; 1619 S(iola) Wekiunow <...> Philip Grigaitis JNŠ 237; 1620 Mikolaÿ Ionaytis <...> Siola Aleknayciow JNŠ 253; 1617 Iakub Iurgajtis de uilla Kiwile JNŠ 206v;

2 Visi straipsnyje pateikti asmenų įvardijimai yra metrikuoti. Prie kiekvieno jų pažymèti metai, kuriais įvardijimas buvo užfiksuotas, istorijos šaltinio santrumpa ir lapo numeris. 
1601 Pagi Proczunow <...> Lucæ Jesaỳtis JNŠ 21v; 1621 S(iola) Medginiow Grig Maciehewicz JNŠ 265; 1619 Thomaß Marczynaitis <...> S(iola) Bilziow JNŠ 235v; 1620 Casper Mikataitis <...> Siola Norunow JNŠ 252v; 1620 Gregor Petraitis <...> Siola Krampiow JNŠ 252v; 1620 Pawel Stanisłowaitis <...> S(ioła) Powilaÿciow JNŠ 253; 1617 Pawel Tomaßewicz de uilla Lidayki JNŠ 200; 1620 S(ioła) Butniunow < ...> Ian Waićiekaitif JNŠ 251v; 1606 S(ioło) Normanciow <...> Maciulis Wenskaitis JNŠ 86v; 1620 Sioła Trumpaiciow <...> Maczë̈ Woyciekowicz JNŠ 251v.

Parapijos kaimuose gyveno krikštijamų kūdikių tėvai, krikšto tėvai, pvz.: 1601 Pagi Rukayciow <...> Patr(ini) Gregorius Bartkuns JNŠ 21; 1601 Pagi Jenkunu <...> Patr(ini) Stanislaus Endrufzaitis JNŠ 24; 1601 Pagi Jakifzkiu <...> Patr(ini) Geniulis Endrufzkaỳtis JNŠ 21; 1601 Pagi Stagia <...> Patr(ini) Simon Gricaitis JNŠ 22; 1601 Patr(ini) Jacobus Jekaytis Pagi Mikalajciunow JNŠ 18v; 1601 Pagi Barifiu <...> Patr(ini) Staś Jenaitis JNŠ 18v; 1606 Sioła Jonaiciow R(odzice) Jerzi Martinaitis JNŠ 86v; 1620 K(um) Stanisław Mikolaitis <...> Sioła Kiepałow JNŠ 253; 1618 Patr(ini) Gregorzy Pietraßajtis de eadem uilla JNŠ 219v; 1617 Par(entes) Iakob Romanaytis <...> de uilla JNŠ 206v; 1621 S(iola) Melniow R(odzic) Simon Woiciechewicz JNŠ 264v.

Pirmieji šių dvinarių ịvardijimų nariai dažniausiai yra tradiciniai krikščioniški vardai, pvz.: 1601 Ambrosius JNŠ 30v³; 1621 Ambrozei JNŠ 262v(2) 1619 Ambroziey் JNŠ 236v; 1619 Ambroźiey் JNŠ 237v; 1620 Ambrozië̈ JNŠ 246; 1620 Ambroziey JNŠ 249; 1620 Ambrozieÿ JNŠ 257 - plg. db. v. Ambraziẽjus (LVKŽ 73); 1601 Andreæ gen. sg. JNŠ 18; 1617 Andreius JNŠ 199; 1617 Andrzey JNŠ 207; 1617 Andrzey JNŠ 198; 1617 Andrzej JNŠ 202v; 1620 Iendrzei JNŠ 248; 1618 Iendrzey JNŠ 221v; 1609 Jendrzë̈ JNŠ 109v; 1620 Jęndrzey் JNŠ 259; 1616 jendrzej JNŠ $191-$ plg. db. v. Andriẽjus (LVKŽ 74); 1621 Anton JNŠ 265v; 1617 Antonius JNŠ 208v - plg. db. v. Antãnas (LVKŽ 76); 1621 Augustin JNŠ 262; 1620 Auguftin JNŠ 254v; 1601 Auguftini gen. sg. JNŠ 20; 1601 Augustin(us) JNŠ 22; 1601 Auguftinus JNŠ 22v - plg. db. v. Augustinas (LVKŽ 85); 1609 Baltromieỳ JNŠ 109; 1609 Battromieÿ JNŠ 109; 1616 Battromiej JNŠ 192v; 1601 Bartholomęus JNŠ 29; 1601 Bartholomæus JNŠ 28; 1618 Bartlomiey் JNŠ 222; 1617 Bartlomiej

3 Vardai ir antrieji antroponimai suregistruoti pagal jų formų abėcèlę. Nurodomos skirtingos asmenvardžių užrašymo lytys, greta nurodant tik po vieną lapą, kuriame ši forma buvo paminėta. Išsamus antroponimų paplitimo registras labai išplèstų šio straipsnio apimtį. Perteikiant asmenvardžius, stengiamasi išsaugoti originalias, bažnytinejje metrikų knygoje fiksuotas lytis.

4 Skliaustuose surašyti numeriai nurodo asmenų, turinčių vienodą vardą, skaičių tame pačiame bažnytinio dokumento lape. 
JNŠ 198v - plg. db. v. Baltramiẽjus (LVKŽ 89); 1617 Casper JNŠ 198; 1617 Caspros JNŠ 204v; 1618 Kasper JNŠ 215 - plg. db. v. Kãsparas (LVKŽ 222); 1601 Chriftophorus JNŠ $25 \mathrm{v}-$ plg. db. v. Kristofòras, Kristòforas (LVKŽ 237); 1621 Elexander JNŠ 265 - plg. db. v. Aleksándras (LVKŽ 65); 1618 Floryan JNŠ 214 - plg. db. v. Florijõnas (LVKŽ 158); 1601 Gaspari gen. sg. JNŠ 20v; 1601 Gasparus JNŠ 18v - plg. db. v. Gãsparas (LVKŽ 164); 1601 Georgius JNŠ 19v; 1617 Iurgis JNŠ 207v; 1601 Jurgis JNŠ 22 - plg. db. v. Jùrgis (LVKŽ 215); 1618 Grygalis JNŠ 220; 1617 Grygalus JNŠ 199v; 1617 Grygalus JNŠ 202v; 1618 Grýgalus JNŠ 218v - plg. db. v. Grigãlius (LVKŽ 188); 1617 Iacobus JNŠ 206v; 1621 Iacub JNŠ 260v; 1617 Iakob JNŠ 206v; 1617 Iakob(us) JNŠ 199; 1617 Iakub JNŠ 243; 1601 Jacobi gen. sg. JNŠ 20v; 1601 Jacobo JNŠ 27; 1601 Jacobus JNŠ 18v; 1601 Jacob(us) JNŠ 20v; 1620 Jaćub JNŠ 253v; 1617 Jakob JNŠ 201v; 1609 Jakub JNŠ 111v — plg. db. v. Jokũ bas (LVKŽ 207); 1617 Ian JNŠ 200; 1617 Ianos JNŠ 197(2); 1609 Jan JNŠ 109; 1601 Joannes JNŠ 21v; 1601 Joannis JNŠ 20v - plg. db. v. Jõnas (LVKŽ 208); 1620 Ieronim JNŠ 251v - plg. db. v. Jerònimas (LVKŽ 204); 1620 Iozeph JNŠ 248; 1601 Josephus JNŠ 18; 1615 jozephus JNŠ 173v plg. db. v. Juõzapas (LVKŽ 214); 1601 Laurentius JNŠ 20; 1616 Laurentj JNŠ 191; 1619 Laurin JNŠ 242; 1616 Lawrÿn JNŠ 192v; 1617 Lawrÿnas JNŠ 199; 1620 Wauwriniec JNŠ 248; 1620 Wawriniec JNŠ 251v - plg. db. v. Laurỹnas (LVKŽ 242); 1601 Lucas JNŠ 28v; 1601 Lucæ gen. sg. JNŠ 18v; 1620 Lukas JNŠ 249 - plg. db. v. Lùkas (LVKŽ 255); 1621 Maciei JNŠ 261v; 1617 Maciey JNŠ 204; 1618 Maciey JNŠ 211v(2); 1620 Maciey JNŠ 257v; 1617 Moteius JNŠ 197v - plg. db. v. Motiẽjus (LVKŽ 279); 1621 Marcin JNŠ 261; 1620 Marczyn JNŠ 247; 1617 Martin JNŠ 206; 1601 Martini gen. sg. JNŠ 22v - plg. db. v. Martỹnas (LVKŽ 264); 1601 Marc(us) JNŠ 18v; 1618 Markus JNŠ 209; 1618 Markuf JNŠ 210v; 1601 Mork(us) JNŠ 28 - plg. db. v. Mõrkus (LVKŽ 279); 1618 Michał JNŠ 210v - plg. db. v. Mýkolas (LVKŽ 270); 1616 Mikolai JNŠ 191; 1617 Mikolay JNŠ 199; 1618 Mikolay JNŠ 210; 1620 Mikolä̈ JNŠ 251; 1617 Mikolaj JNŠ 198; 1601 Nicolai JNŠ 20; 1601 Nicolaus JNŠ 19v - plg. db. v. Mikalõjus (LVKŽ 270); 1617 Patroś JNŠ 199; 1601 Petri gen. sg. JNŠ 20; 1601 Petrus JNŠ 19v; 1620 Piotr3 JNŠ 252 - plg. db. v. Pẽtras (LVKŽ 299); 1601 Pauli gen. sg. JNŠ 21v; 1601 Paulus JNŠ 19v; 1601 Paul(us) JNŠ 26 - plg. db. v. Paũlius (LVKŽ 298); 1609 Pawel JNŠ 112; 1617 Pawel JNŠ 200(2); 1617 Powilaf JNŠ 204v - plg. db. v. Póvilas (LVKŽ 301); 1619 Philip JNŠ 237 - plg. db. v. Pilỹpas (LVKŽ 300); 1601 Sebaftianus JNŠ 21; 1621 Sebestian JNŠ 264; 1620 Sebeftian JNŠ 251v - plg. db. v. Sebastijõnas (LVKŽ 325); 1601 Simon JNŠ 22; 1618 Symon JNŠ 213v - plg. db. v. Simonas (LVKŽ 329); 1601 Stanislaus 
JNŠ 21; 1618 Stanifłaus JNŠ 221; 1618 Stanislaw JNŠ 210; 1619 Stanisław JNŠ 233v; 1617 Stanifław JNŠ 203v; 1621 Stanisła(w) JNŠ 270v - plg. db. v. Stanislovas (LVKŽ 335); 1617 Stephan JNŠ 193; 1601 Stephanus JNŠ 18v - plg. db. pvd. Stẽponas (LVKŽ 336); 1601 Thomas JNŠ 20; 1601 Thomæ gen. sg. JNŠ 20v; 1616 Tomas JNŠ 193 - plg. db. v. Tòmas (LVKŽ 350); 1618 Tomaßus JNŠ 213; 1617 Tomasz JNŠ 200 - plg. db. v. Tamõšius (LVKŽ 341); 1620 Walentin JNŠ 248; 1620 Walentÿn JNŠ 256; 1601 Valentini gen. sg. JNŠ 20; 1601 Valentinus JNŠ $18 \mathrm{v}$ - plg. db. v. Valentinas (LVKŽ 363); 1620 Woiciech JNŠ 257; 1617 Woyciech JNŠ 207; 1618 Woyciechüs JNŠ 211; 1617 Wojtechüs JNŠ 197 - plg. db. v. Vaitiêkus (LVKŽ 361); 1616 Vrban JNŠ 192v; 1601 Vrbani gen. sg. JNŠ 20v; 1601 Vrbanus JNŠ 22; 1618 Vrban(us) JNŠ 214v - plg. db. v. Urbonas (LVKŽ 353); 1617 Zygmont JNŠ 207 - plg. db. v. Zìgmantas (LVKŽ 384).

Mažiau pastebėta kanoninių krikščioniškų vardų trumpinių, pvz.: 1621 Gabris JNŠ 266v - plg. db. v. Gabrỹs (LVKŽ 160) < Gabriēlius (LVKŽ 160); 1616 Grig JNŠ 192; 1617 Gryg JNŠ; 1620 Grigas JNŠ 253v; 1616 grigas JNŠ 193; 1617 Grygaf JNŠ 207v; 1617 Grygaś JNŠ 202v - plg. db. v. Grigas (LVKŽ 188) < Grigãlius (LVKŽ 188); 1621 Sim JNŠ 260 - plg. db. v. Sìmas < Sìmonas (LVKŽ 329); 1618 Staniuf JNŠ 210v - plg. db. v. Stãnius (LVKŽ 335) < Stanislovas (LVKŽ 335); 1618 Stasius JNŠ 210; 1617 Stäsius JNŠ 205; 1601 Stafius JNŠ 18 - plg. db. v. Stãsius (LVKŽ 335) < Stanislovas (LVKŽ 335); 1620 Walenti gen. sg. JNŠ 253v; 1617 Walenty JNŠ 202; 1616 Walenty JNŠ 193 - plg. db. v. Vãlentas, Valeñtas (LVKŽ 363).

Pasitaikè deminutyvinių krikštavardinių vardų formų, pvz.: 1617 Andrutis JNŠ 197 - plg. db. v. Añdrius (LVKŽ 75) < Andriẽjus (LVKŽ 74); 1620 Antul JNŠ 247 - plg. db. v. Ántas (LVKŽ 76) < Antãnas (LVKŽ 76); 1601 Jonelis JNŠ 26 - plg. db. v. Jõnas (LVKŽ 208); 1601 Jurgelis JNŠ $27 \mathrm{v}-$ plg. db. v. Jùrgis (LVKŽ 215); 1601 Mikucia gen. sg. JNŠ 22; 1618 Mikutys JNŠ 220; 1617 Mikutyf JNŠ 205v - plg. db. v. Mìkas (LVKŽ 270) < Mikalõjus (LVKŽ 270); 1621 Tamul JNŠ 259v - plg. db. v. Tòmas (LVKŽ 350).

Antrieji dvinarių ịvardijimų nariai - tai krikščioniškos kilmès asmenvardžiai su priesagomis arba be priesagų, kurie toliau analizuojami darybos aspektu.

\section{Antroponimų darybos tendencijos}

Lietuvių pavardes, kilusias iš populiariausių krikšto vardų lyčių (ilgųiu, lietuvių kalboje susidariusiu ar skolintų trumpinių, mažybinių bei kitokių priesagų vedinių) išsamiai yra aprašęs Aleksandras Vanagas (1974: 86-152; 
1977: 48-92; 1980: 52-95; 1982: 73-97; 1983: 73-103). Nemažą dali šios kilmès pavardžių išaiškino Zigmas Zinkevičius (1977a: 66-89; 2005: 16-43; 2007: 22-23; 2008: 343-484; 2010: 9-106). Daugiausia šio tipo pavardžių yra išanalizuota Lietuviu pavardžiu žodyno dvitomyje (Vilnius: Mokslas, 19851989). Nagrinejjant lietuvių pavardžiu formavimosi procesą, krikščioniškos kilmès asmenvardžius aptarė Vitalija Maciejauskienè (1991: 219; 222-223; 230-232; 233-236). Tarp nelietuviškos kilmės XVI-XVIII a. kauniečių antroponimų daugiausia buvo kilusių iš krikščioniškų vardų (XVI a. - 29 \%, XVII a. - 31 \%, XVIII a. - 32 \%) (Ragauskaite 2005: 119, 125, 133).

Aptariami 1599-1621 m. Joniškio parapijos kaimų gyventojų krikščioniškos kilmés asmenvardžiai suklasifikuoti ị dvi grupes: 1) antropinimai su lietuviškomis -aitis, -(i)onis, -(i)ūnas, -(i)uitis ir slaviškomis -evič, -ovič patroniminèmis priesagomis, su deminutyvinèmis priesagomis ir 2) asmenvardžiai be šių priesagų (dèl šios klasifikacijos dar žr. Maciejauskienè 1993: 40; Ragauskaitė 2018a: 104-106; 2019a: 182). Antroponimai yra rekonstruojami iš patronimų ir nepatroniminès kilmès asmenvardžių. Atkurtos antroponimų formos pažymimos rekonstrukcijos ženklu ir pateikiamos pagal abėcèlę. Šios formos lyginamos su dabartinėmis lietuvių pavardèmis. Kaip minèta, 1599-1621 m. Joniškio parapijos krikšto metrikų knygoje buvo užrašyti 556 kaimų gyventojų krikščioniškos kilmès asmenvardžiai. Prie pirmosios grupès priskirti 552 (99,28 \% visų antrųų antroponimų) asmenvardžiai. Jie pateikiami pagal priesagu produktyvumą:

-aitis (rašymas varijuoja: -aycis, -aitis, -aitif, -aitýs, -aytis, -áytis, -aytis, -aytis, -aÿtis, -ajtis, -atis) - 359 (64,55 \%) antroponimai: *Adom a it is : 1620 Adomaitis JNŠ 258v. Plg. db. pvd. Adomáitis (LPŽ I 65); *Andrekaitis : 1617 Andrekaytis JNŠ 206v. Plg. db. pvd. Andrekáitis (LPŽ I 99); *Andrukaitis: 1617 Andrukaytis JNŠ 207v; 1617 Andrukajtis JNŠ 198v. Plg. db. pvd. Andrukáitis (LPŽ I 103); *A ug ust i na it is : 1601 Auguftinaitis JNŠ 24v; 1617 Augustẏnajtis JNŠ 199. Plg. db. pvd. Augustináitis (LPŽ I 137); * Bagdo naiti s : 1621 Bagdonaitis JNŠ 271. Plg. db. pvd. Bagdonaitis (LPŽ I 153); * B a n a it i s : 1601 Banaitis JNŠ 25; 1601 Banaytis JNŠ 30v; 1617 Banajtis JNŠ 203v. Plg. db. pvd. Banáitis (LPŽ I 184); *B a ri s a it is : 1601 Barifaitis JNŠ 26. Plg. db. pvd. Barisáitis (LPŽ I 197); * B art ka it is : 1601 Bartkaitis JNŠ 25. Plg. db. pvd. Bartkáitis (LPŽ I 203); * B a r to š a it i s : 1618 Bartoßaytis JNŠ 219v. Plg. db. pvd. Bartošáitis (LPŽ I 205); * B e r no ta it i s : 1619 Bernotaitis JNŠ 234v. Plg. db. pvd. Bernotáitis (LPŽ I 240); *Č e p a i ti s : 1601 Czepaitis JNŠ 22v; 1620 czepaitis JNŠ 247; 1618 Czepaytis JNŠ 221v; 1618 czepaytis JNŠ 219. Plg. db. pvd. Čepáitis (LPŽ I 410); *Endru ša i t is : 1601 Endrufzaitis JNŠ 24. Plg. db. pvd. Endrušaitis (LPŽ I 577); * Endr u ška it i s : 
1601 Endrufzkaẏtis JNŠ 21. Plg. db. pvd. Endruškaitis (LPŽ I 577); * Grigai ti s : 1609 Grigaitis JNŠ 109; 1615 grigaitis JNŠ 174v; 1617 Grygajtis JNŠ 198v. Plg. db. pvd. Grigáitis (LPŽ I 710-711); *Grigalaiti s: 1620 Grigalaitis JNŠ 243; 1601 Gryggalaytis JNŠ 22; 1617 Grygałajtis JNŠ 202. Plg. db. pvd. Grigaláitis (LPŽ I 711); *Griškaitis: 1601 Grifzkaitis JNŠ 22. Plg. db. pvd. Griškáitis (LPŽ I 721); *Jakaitis: 1620 Iakaitis JNŠ 243; 1617 Jakaytis JNŠ 208. Plg. db. pvd. Jakáitis (LPŽ I 785); *Ja s a it i s : 1620 Iasaitis JNŠ 258. Plg. db. pvd. Jasáitis (LPŽ I 813); *Jo ca it is : 1621 Iocaitis JNŠ 264v. Plg. db. pvd. Jocáitis (LPŽ I 835); *Jok ūba it i s : 1621 Iacubaitis JNŠ 264v; 1620 Iakubaitis JNŠ 258; 1617 Iakübajtis JNŠ 198v; 1620 Iokubaÿtis JNŠ 255v; 1616 jocubaitis JNŠ 191v; 1616 jokubaitis JNŠ 192v. Plg. db. pvd. Jókūbaitis, Jokūbáitis (LPŽ I 839); *Jo na it is : 1621 Ianaitis JNŠ 260; 1617 Ianaytis JNŠ 205v; 1617 Ianaytiš JNŠ 204; 1617 Ianajtis JNŠ 197; 1620 Ionaitis JNŠ 241v; 1620 Ionaitỳs JNŠ 254; 1617 Ionaytis JNŠ 199; 1601 Jonaitis JNŠ 20; 1616 jonaitis JNŠ 193; 1618 Jonaytis JNŠ 213; 1601 Jonaytis JNŠ 20. Plg. db. pvd. Jonáitis (LPŽ I 841); *Jonkait is: 1601 Jonkaitis JNŠ 30. Plg. db. pvd. Jonkáitis (LPŽ I 843); *Jo n ulait is: 1620 Ianulaitis JNŠ 249v. Plg. db. pvd. Jonulaitis (LPŽ I 844); *Jo n u ša it is : 1621 Ianußaitis JNŠ 269; 1618 Ianußaytis JNŠ 210; 1617 Ianu்szaytis JNŠ 199; 1604 Jonußaitis JNŠ 48. Plg. db. pvd. Jõnušaitis, Jonušáitis (LPŽ I 844); *Juknaitis : 1618 Iuknaytis JNŠ 212. Plg. db. pvd. Juknáitis (LPŽ I 852); *Jurgaitis : 1620 Iurgaitis JNŠ 251v; 1617 Iurgaytis JNŠ 204v; 1617 Iurgajtis JNŠ 206v; 1601 Jurgaitis JNŠ 19v; 1615 jurgaitis JNŠ 174v; 1601 Jurgaytis JNŠ 22. Plg. db. pvd. Jùrgaitis, Jur̃gaitis, Jurgáitis, Jurgaitis (LPŽ I 866); *Jurkaitis : 1617 Iurkaycis JNŠ 208. Plg. db. pvd. Jurkáitis (LPŽ I 868-869); *Ju šk a it i s : 1620 Juskaitis JNŠ 259. Plg. db. pvd. Juškáitis (LPŽ I 874); *Ka s p a ra it i s : 1620 Casparaitif JNŠ 249v. Plg. db. pvd. Kãsparaitis, Kasparáitis, Kasparaitis (LPŽ I 940); * La u ry na it is : 1601 Laurinaýcia gen. sg. JNŠ 19v; 1621 Laurinaitis JNŠ 260(2); 1601 Laurinaytis JNŠ 18v; 1618 Lawrynaytis JNŠ 213v; 1618 Lawrynaytis JNŠ 209v; 1617 Lawrynnaytis JNŠ 205; 1617 Lawrynajtis JNŠ 203; 1618 Lawrynajtis JNŠ 213; 1618 Lawrynatis JNŠ 221. Plg. db. pvd. Laurynáitis (LPŽ II 35); *Lukošaitis: 1618 Lukaßaytis JNŠ 212; 1601 Lukoßaitis JNŠ 25; 1621 Lukoszaitis JNŠ 264v; 1601 Lukoszaỳtis JNŠ 28v. Plg. db. pvd. Lukošáitis (LPŽ II 114); *Ma cait is: 1601 Macaitis JNŠ 22; 1602 Macaẏtis JNŠ 39; 1618 macaytis JNŠ 222; 1617 Matfaytis JNŠ 206; 1618 matfaỳtis JNŠ 218; 1617 Matsajtis JNŠ 198. Plg. db. pvd. Macáitis (LPŽ II 30); *Martynaitis : 1601 Martinaýcia gen. sg. JNŠ 22; 1601 Martinaitis JNŠ 25; 1617 Martinaytis JNŠ 200; 1617 martinaytis JNŠ 200v; 1617 Martinajtis JNŠ 202v; 1617 Martynajtis JNŠ 203v; 1617 Martjnajtis JNŠ 196v. 
Plg. db. pvd. Martynáitis (LPŽ II 167); * Mart in ka it i s : 1601 Martinkaitis JNŠ 24v. Plg. db. pvd. Martinkáitis (LPŽ II 168); *Mata i t is: 1618 matáytis JNŠ 216. Plg. db. pvd. Matáitis (LPŽ II 177); *Mat u la i ti s : 1616 Matułaitis JNŠ 191v. Plg. db. pvd. Matuláitis (LPŽ II 183); ${ }^{*}$ Mi ka it i s : 1601 Mikaycia gen. sg. JNŠ 20v; 1601 Mikaýcia gen. sg. JNŠ 20v; 1616 Mikaitis JNŠ 192v; 1601 Mikaỳtis JNŠ 27; 1619 Mikaÿtis JNŠ 231v; 1601 Mikajtis JNŠ 28. Plg. db. pvd. Mikáitis (LPŽ II 225); *Mi k el a i t is : 1601 Mikielaitis JNŠ 30. Plg. db. pvd. Mikelaitis, Mikeláitis, Mikelaitis (LPŽ II 228); *My ko la i t is : 1620 Mikolaitis JNŠ 253. Plg. db. pvd. Mykoláitis (LPŽ II 231); *Mikutaitis: 1601 Mikutaitis JNŠ 22; 1617 Mikutajtis JNŠ 198v. Plg. db. pvd. Mìkutaitis, Mikutáitis (LPŽ II 236); *Motiejaitis : 1601 Moteiaytis JNŠ 27. Plg. db. pvd. Motiejáitis (LPŽ II 274); *Mo ti e k a it is : 1601 Motekaitis JNŠ 25v. Plg. db. pvd. Motiekáitis (LPŽ II 274); * Pa tra i ti s : 1617 Patraytis JNŠ 200v. Plg. db. pvd. Patráitis (LPŽ II 406); *Pa u la it i s: 1617 Pawlaytis JNŠ 207v. Plg. db. pvd. Pauláitis (LPŽ II 408); *Peči ulait is: 1616 pećiulaitis JNŠ $192 \mathrm{v}$. Plg. db. pvd. Pèčiulaitis, Pečiuláitis, Pečiulaitis (LPŽ II 420); *Petraitis: 1601 Petraitis JNŠ 21; 1609 petraitis JNŠ 111; 1601 Petraytis JNŠ 19v; 1601 Petraỳtis JNŠ 19v; 1620 Petraÿtis JNŠ 256; 1618 Pietraytis JNŠ 213v. Plg. db. pvd. Petráitis (LPŽ II 437); *Petrikait is: 1620 Petricaitis JNŠ 251; 1601 Petrikaitis JNŠ 25v; 1601 Petrikaytis JNŠ 18v; 1617 Pietrykaytis JNŠ 205. Plg. db. pvd. Petrikáitis (LPŽ II 440); *Pet ri la i t i s : 1601 Petrilaitis JNŠ 30v; 1604 Petrilaÿtis JNŠ 48v. Plg. db. pvd. Petrilaitis (LPŽ II 441); * Pet ru š a it is : 1618 Pietrußaytis JNŠ 222. Plg. db. pvd. Petrušáitis (LPŽ II 444); *Povila it i s: 1604 Powełaytis JNŠ 48v; 1619 Powilaitis JNŠ 235; 1616 powilaitis JNŠ 191; 1609 Powilaytis JNŠ 109v; 1601 Powilaytis JNŠ 26v; 1621 Powẏlaitis JNŠ 261; 1617 Powilajtis JNŠ 202v. Plg. db. pvd. Póvilaitis, Poviláitis, Povilaitis (LPŽ II 496, 497); *S a ba i t is : 1620 Sabaitis JNŠ 258. Plg. db. pvd. Sabáitis (LPŽ II 651); *Stanaitis: 1601 Stanaitis JNŠ 24; 1621 stanaitis JNŠ 270v; 1619 stanaitif JNŠ 237v; 1601 Stanaytis JNŠ 19v; 1601 Stanaytis JNŠ 30; 1617 Stanajtis JNŠ 197. Plg. db. pvd. Stanáitis (LPŽ II 798); *S ta n i slov a it i s: 1620 Stanislowaitis JNŠ 253; 1621 Stanslowaitis JNŠ 263v. Plg. db. pvd. Stanislováitis (LPŽ II 801); *S ta n i u la i t i s : 1609 Staniulaitis JNŠ 109; 1601 Staniułaỳtis JNŠ 21v. Plg. db. pvd. Staniuláitis (LPŽ II 802); *Sta n ka it i s: 1601 Stankaytis JNŠ 18v. Plg. db. pvd. Stankáitis (LPŽ II 802); *S ta s a it i s : 1620 Stasaitis JNŠ 256; 1601 Stafaitis JNŠ 29v. Plg. db. pvd. Stasáitis (LPŽ II 807); *Šimait is : 1620 Szÿmaitis JNŠ 257; 1620 S3ymaitis JNŠ 256. Plg. db. pvd. Šimáitis (LPŽ II 928); * Ta mo ša i t is : 1620 Tamoßaitis JNŠ 251v; 1620 Tamoßaÿtis JNŠ 257v. Plg. db. pvd. Tamošáitis (LPŽ II 1016); *Vai ti e ka it i s : 1601 Waỳtiekajtis JNŠ 20v. Plg. db. pvd. Vaitiekáitis (LPŽ II 
1139); *Venskaitis: 1606 Wenskaitis JNŠ 86v. Plg. db. pvd. Venskáitis (LPŽ II 1190).

-(i)ūnas (rašymas įvairuoja: -(i)un, -(i)unas, -(i)unaf, -(i)unaś, -(i)uns, -unis, -unoś) - 62 (11,15\%) asmenvardžiai: *Andriej ūnas : 1618 Andreiunaf JNŠ 210v. Plg. db. pvd. Andriejúnas (LPŽ I 100); *Baltramiejūnas: 1617 Baltromieiunas JNŠ 198. Plg. db. pvd. Baltramiejūnas (LPŽ I 179); * B a rta ši ūn a s: 1617 Bartoszunis JNŠ 202. Plg. db. pvd. Bartašiúnas (LPŽ I 202); * B artk ūnas : 1601 Bartkuns JNŠ 21. Plg. db. pvd. Bartkúnas (LPŽ I 204); *Griciūnas: 1621 Gricun JNŠ 262v; 1618 Grycun JNŠ 211; 1617 Grýcunoś JNŠ 197v. Plg. db. pvd. Griciúnas (LPŽ I 709); *Grigali ūnas: 1620 Grigalunas JNŠ 256; 1618 Grygalunas JNŠ 210; 1601 Grigaluns JNŠ 19v. Plg. db. pvd. Grigaliúnas (LPŽ I 711); *Jo n k ūn a s: 1621 Iankun JNŠ 267v; 1601 Jonkuns JNŠ 24v. Plg. db. pvd. Jonkúnas (LPŽ I 22); *Jurkūnas: 1601 Jurkunas JNŠ 19; 1601 Jurkuns JNŠ 19. Plg. db. pvd. Jurkúnas (LPŽ I 870); *Krišči ūnas: 1618 Krýsciun JNŠ 211v; 1601 Krifciuns JNŠ 22. Plg. db. pvd. Kriščiúnas (LPŽ I 1081); *Lukoši ūnas: 1601 Lukoßiuns JNŠ 20v; 1620 Lukoßuns JNŠ 251v. Plg. db. pvd. Lukošiúnas (LPŽ II 114); *Maciūnas: 1617 Maciunas JNŠ 197; 1618 Maciunaf JNŠ 216v. Plg. db. pvd. Maciúnas (LPŽ II 125); *Mikalojūnas: 1601 Mikaloiuns JNŠ 20v; 1621 Mikoloiuns JNŠ 267. Plg. db. pvd. Mikalojúnas (LPŽ II 227); *Motiejūnas: 1617 Mateiunaś JNŠ 202v; 1601 Mateiuns JNŠ 20v; 1618 Matieiun JNŠ 211; 1618 mocieiunaf JNŠ 219v; 1617 Moteiunas JNŠ 198; 1617 Moteiunaf JNŠ 208v; 1618 moteiunaf JNŠ 220; 1601 Moteiuns JNŠ 18v. Plg. db. pvd. Motiejúnas (LPŽ II 274); * Pa c i ūn as : 1618 Patfunaf JNŠ 214v. Plg. db. pvd. Paciúnas (LPŽ II 361); *Petroši ūnas: 1601 Petrofiuns JNŠ 21v. Plg. db. pvd. Petrošiúnas (LPŽ II 442); *Stankūnas: 1617 Stankunaś JNŠ 197; 1604 Stankuns JNŠ 48. Plg. db. pvd. Stankúnas (LPŽ II 804); *Sta s i ūnas: 1601 Stafiuna gen. sg. JNŠ 22; 1616 Stasiunas JNŠ 192; 1617 Stasiunas JNŠ 197; 1601 Stafiuns JNŠ 23. Plg. db. pvd. Stasiúnas (LPŽ II 810); * Tamo ši ūn as : 1601 Tamoßiuns JNŠ 23v. Plg. db. pvd. Tamošiúnas (LPŽ II 1016); *Vaitiek ūnas: 1616 Waitiekun JNŠ 191v; 1601 Wajtekuns JNŠ 29v; 1618 Woyciechunaf JNŠ 216; 1617 Wojtechünas JNŠ 197v. Plg. db. pvd. Vaitiekúnas (LPŽ II 1140); *Vait k ū nas: 1601 Waytkuns JNŠ 18; 1617 Woytkunaś JNŠ 199v; 1617 Wojtkunoś JNŠ 208v. Plg. db. pvd. Vaitkúnas (LPŽ II 1141); *Valanči ūnas: 1621 Wałanciun JNŠ 269v. Plg. db. pvd. Valančiúnas (LPŽ II 1146); *Ven sk ūnas: 1601 Węskuns JNŠ 23. Plg. db. pvd. Venskúnas (LPŽ II 1190-1191) bei kt.

-ovič (rašoma: -(i)owicz, -owicz, -owicz) - 59 (10,61 \%) antroponimai: 1618 Bartkowicz JNŠ 214; 1617 Bernatowicz JNŠ 197v; 1620 Czapowicz 
JNŠ 249; 1618 Danilowicz JNŠ 221; 1618 Gregorowicz JNŠ 219; 1618 Gregorzowicz JNŠ 218v; 1618 Grycunowicz JNŠ 211v; 1617 Grygowicz JNŠ 207v; 1621 Iakubowicz JNŠ 249v; 1618 Iakünowicz JNŠ 214; 1618 Iankunowicz JNŠ 212; 1617 Ianowicz JNŠ 197v; 1618 Ianußkowicz JNŠ 214v; 1618 Iekonowicz JNŠ 216v; 1618 Janowicz JNŠ 217v; 1618 Kafperowicz JNŠ 217v; 1620 Laurzinowicz JNŠ 241v; 1618 Macieiowicz JNŠ 210v; 1618 Marcinowicz JNŠ 217v; 1617 Martinowicz JNŠ 199; 1618 Matyiaßowicz JNŠ 222; 1618 Michałowicz JNŠ 209v; 1620 Mikołaiowicz JNŠ 246; 1618 Oftafowicz JNŠ 211v; 1620 Pawłowicz JNŠ 249v; 1618 Piotrowicz JNŠ 214v; 1619 Romanowicz JNŠ 236v; 1601 Stanisławowicz JNŠ 20v; 1618 Staniułowicz JNŠ 210v; 1618 Stasiunowicz JNŠ 216; 1618 Stefanowicz JNŠ 222; 1618 Stephanowicz JNŠ 212v; 1617 Walentynowicz JNŠ 207; 1621 Wawrinowicz JNŠ 262; 1618 Woyciechowicz JNŠ 219v; 1618 Woytkunowicz JNŠ 218v ir kt.

-(i)uitis (rašoma: -(i)uytis, -uitis, -uytis) - 38 (6,83 \%) asmenvardžiai: *Jonuitis: 1618 Ianuytis JNŠ 209. Plg. db. pvd. Jonùitis (LPŽ I 844); *Martynuitis: 1620 Martinuitis JNŠ 243; 1618 Martinuytis JNŠ 214. Plg. db. pvd. Martynuĩtis (LPŽ II 169); *Motiejuitis : 1620 Mateiuytis JNŠ 253. Plg. db. pvd. Motiejuitis (LPŽ II 274) ir kt.

-(i)evič (rašoma: -ewẏz, -(i)ewicz, -iewicz) - 30 (5,42 \%) antroponimų: 1621 Ambrozewicz JNŠ 269v; 1618 Andrzeiewicz JNŠ 212; 1618 Baniewicz JNŠ 217v; 1618 Barthoßewicz JNŠ 213v; 1621 Iendrzeiewicz JNŠ 262; 1621 Iozewicz JNŠ 265v; 1618 Iurgiewicz JNŠ 216v; 1620 Janiskiewicz JNŠ 249v; 1618 Macieiewicz JNŠ 211v; 1618 mikołaiewicz JNŠ 216; 1601 Ostafieiewicz JNŠ 19v; 1621 Paulukiewicz JNŠ 264; 1621 Peczułewicz JNŠ 264; 1601 Thomafzewy்cz JNŠ 21; 1618 więckiewicz JNŠ 215v; 1621 Woicieiewicz JNŠ 270v(2) bei kt.

-onis (rašoma -onis) - 1 (0,18 \%) asmenvardis: *Juknonis: 1617 Iuknonis JNŠ 200. Plg. db. pvd. Juknónis (LPŽ I 853).

Užfiksuoti tik $3(0,54 \%$ visų atkurtų) antroponimų vartojimo atvejai su deminutyvinėmis priesagomis. Kai kada šio tipo priesagos galëjo turèti ir patroniminę reikšmę (dar žr. Zinkevičius 1977a: 241; Maciejauskienė 1991: 227-228; 1993: 43; Ragauskaite 2005: 100-101; 2018a: 105-114; 2019b: 180-190):

-elis (rašoma -(i)elis) - 1 (0,18 \%) asmenvardis: *Mackelis : 1604 Mackielis JNŠ 48. Plg. db. pvd. Mackẽlis (LPŽ II 125);

-(i)ulis (rašoma -(i)ulis) - $1(0,18 \%)$ antroponimas: *Ka s i u li s : 1601 Kasiulis JNŠ 27v. Plg. db. pvd. Kasiùlis (LPŽ I 939);

-utis (rašoma -ütys் $-1(0,18 \%)$ asmenvardis: *Mikutis : 1617 Mikütyś JNŠ 197. Plg. db. pvd. Mikùtis (LPŽ II 236). 
XVI a. pabaigos - XVII a. pradžios Joniškio parapijos gyventojų antroponimų antroje dvinario įvardijimo vietoje dažniausi yra patroniminės kilmės asmenvardžiai. Jų daryba paliudijo lietuviškos patroniminès priesagos -aitis produktyvumą (359, t. y. 65 \%). Tarp XVII a. pradžios vilniečių patronimų, sudarytų su lietuviškomis priesagomis, taip pat dominavo priesagos -aitis vediniai (Zinkevičius 1977a: 56-63). Todèl buvo spejjama, kad visai etnografinei Lietuvai buvo bendra tèvavardžių su priesaga -aitis sistema (Zinkevičius 1977b: 153-155). Tačiau didžiausia priesagos -aitis vedinių koncentracija nustatyta Žemaitijoje ir Vakarų Aukštaitijoje, nors šios priesagos derivatų užrašyta ir įvairiose kitose Lietuvos vietose (Maciejauskienè 1991: 242). Ne tik priesaga -aitis, bet ir kitos lietuvių pavardžių tėvavardinès priesagos -ènas, -onis, -ūnas turi daugiau ar mažiau apibrèžtus priesagu paplitimo arealus Lietuvoje. Antroponimai su priesaga -onis labiausiai paplitę Rytų Lietuvoje ir kai kuriose Pietų Lietuvos vietovėse. Priesagos - ūnas vediniai taip pat dažniausi Rytų Lietuvoje, nors pasitaiko jų ir Pietų Lietuvoje (Maciejauskienė 1977: 161-163; 1991: 242).

Kita asmenvardžiu grupè yra gerokai mažesnè. Ją sudaro tik 4 antroponimai (0,72 \%). Tai: *B a rtku s: 1601 Bartkus JNŠ 21v. Plg. db. pvd. Bar̃tkus (LPŽ I 204); *Jurku s: 1601 Jurkaus gen. sg. JNŠ 21v. Plg. db. pvd. Jur̃kus (LPŽ I 870); *Petrošius: 1604 Petrofius JNŠ 48. Plg. db. pvd. Petrõ̌sius (LPŽ II 442); *Venskus: 1601 Venskaus gen. sg. JNŠ 20. Plg. db. pvd. Veñskus (LPŽ II 1190-1191). Kaip matyti, Joniškio parapijos krikščioniškos kilmès asmenvardžių formos yra labai įvairios.

\section{Antroponimai, nef unkcionuojantys dabartiniame lietuviu vardyne}

XVI a. pabaigos - XVII a. pradžios Joniškio parapijos 146 atkurti krikščioniškos kilmès antroponimai lyginami su dabartinèmis lietuviu pavardèmis. Nesuradus tikslių atitikmenų mūsų dienų vardyne, pateikiami keli būdingesni atitinkamos šaknies asmenvardžiai, pvz.: *And rušk a it is : 1617 Andruszkajtis JNŠ 198. Dèl andrušk- plg. db. pvd. Andruškà, Andruškẽvičius, Andrùškis (LPŽ I 104); *B a l tra mi i jai t is : 1620 Baltromæiaytis JNŠ 259. Dèl baltramiej- plg. db. pvd. Baltramiejúnas (LPŽ I 179); * Baltr uškait is : 1621 Baltrußkaitis JNŠ 266. Dèl baltrušk- plg. db. pvd. Baltruškà, Baltruškẽvičius (LPŽ I 181); *Ba n i u šku it is : 1621 Baniußkuitis JNŠ 265. Dèl baniušk- plg. db. pvd. Baniuškáitis (LPŽ I 188); *B e n i u ša it is : 1601 Beniuszaytis JNŠ 27. Dèl beniuš- plg. db. pvd. Beniušẽvičius, Beniùšis (LPŽ I 233); *Bertaša it is : 1609 Bertaszaitis JNŠ 111v. Dèl bertaš- plg. db. pvd. 
Bertašáuskis, Bertašẽvičius, Bertãšius (LPŽ I 241); *Berta ši ūnas : 1601 Bertafiuns JNŠ 25. Dèl bertaš- plg. db. pvd. Bertašáuskis, Bertašẽvičius, Bertãšius (LPŽ I 241); *Gabruitis: 1601 Gabruitis JNŠ 25. Dèl gabrplg. db. pvd. Gabráitis (LPŽ I 601); *Gasparuitis: 1621 gasparuitis JNŠ 264v. Dèl gaspar- plg. db. pvd. Gasparáitis (LPŽ I 629); *Ge nu la it i s : 1621 Genułaitis JNŠ 260v. Dèl genul- plg. db. pvd. Genùlis (LPŽ I 653); * Gricaitis: 1601 Gricaitis JNŠ 22; 1601 Gricaỳtis JNŠ 29. Dèl gric- plg. db. pvd. Grìcas, Gricẽvičius, Gricỹs, Griciùkas, Griciúnas (LPŽ I 709); *Jaku laiti s: 1601 Jokułaitis JNŠ 26. Dèl jakul- plg. db. pvd. Jakuláuskas, Jakulenis, Jakulẽvičius, Jakùlis (LPŽ I 792); *Ja n k ūna it i s: 1620 Iankunaitis JNŠ 255v. Dèl jankūn- plg. db. pvd. Jankúnas, Jankūnãvičius (LPŽ I 802); *Ja sk a i t i s : 1620 Iaskaitis JNŠ 257. Dèl jask- plg. db. pvd. Jaska, Jaskáuskas, Jaskelis, Jaskẽvičius (LPŽ I 817); *Joci ūnas: 1620 Jaciun JNŠ 249v; 1601 Jocuns JNŠ 18v. Dèl joc- plg. db. pvd. Jocáitis, Jõcas, Jocẽvičius, Jõcius, Jocónis (LPŽ I 835); *Jon uluitis: 1620 Ianułuitis JNŠ 248. Dèl jonul- plg. db. pvd. Jonulaitis (LPŽ I 844); *Jo nu ška it is: 1621 Ianußkaitis JNŠ 261; 1618 Ianußkaytis JNŠ 211v; 1617 Ianu்szkaytiš JNŠ 199; 1620 Ionuscaitis JNŠ 256v; 1616 jonußkaitis JNŠ 192v; 1601 Jonufzkaitis JNŠ 26v. Dèl jonuškplg. db. pvd. Jonuškà, Jonuškẽvičius, Jonùškis (LPŽ I 844); *Ju ka it i s : 1604 Jukaitis JNŠ 48. Dėl juk- plg. db. pvd. Jukãvičius, Jùkelis, Jukénas (LPŽ I 852); *Ju oz u i t is : 1620 Iazuitif JNŠ 249v. Dèl juoz- plg. db. pvd. Juozáitis (LPŽ I 861); *Ju rgu i t i s: JNŠ 201v. Dèl jurg- plg. db. pvd. Jùrgaitis, Jur̃gaitis, Jurgáitis (LPŽ I 866); *Ju rku it is: 1601 Jurkuitis JNŠ 29v. Dèl jurk-plg. db. pvd. Jurkáitis (LPŽ I 868-869); *Krikštanaitis: 1601 Krixtanaytis JNŠ 20. Dèl krikštan- plg. db. pvd. Krikštãnas, Krikštanãvičius (LPŽ I 1076); * Ma cel u i t is : 1620 Macaluitis JNŠ 248. Dèl macel-plg. db. pvd. Mãcelaitis (LPŽ II 122); *Macikait is: 1601 Macikaitis JNŠ 30v. Dèl macik- plg. db. pvd. Macikas (LPŽ II 124); *Ma ciu la it is : 1609 Maciulaitis JNŠ 114. Dèl maciul-plg. db. pvd. Maciulãvičius, Maciulẽvičius, Maciuliónis, Maciùlis (LPŽ II 124-125); *Ma ci u lu i ti s : 1601 Maciuluitis JNŠ 28v. Dèl maciulplg. db. pvd. Maciulãvičius, Maciulẽvičius, Maciuliónis, Maciùlis (LPŽ II 124-125); *Macuitis : 1621 Macuitis JNŠ 262v. Dèl mac- plg. db. pvd. Macáitis (LPŽ II 121); *Mačiuluiti s : 1620 Maczuluitis JNŠ 251v. Dèl mačiul-plg. db. pvd. Màčiulaitis, Mačiuláitis (LPŽ II 129); *Ma s i u l u i t i s : 1621 Masiułuitis JNŠ 264. Dèl masiul- plg. db. pvd. Masiuláitis (LPŽ II 173); *Ma su it is : 1621 Mafuitis JNŠ 263. Dèl mas- plg. db. pvd. Masáitis (LPŽ II 170); *Mika il a i t is: 1601 Mikaiłaỳtis JNŠ 29v; 1601 Mikayłajcia gen. sg. JNŠ 23v. Dèl mikail- plg. db. pvd. Mikáila, Mikáilas, Mikailiónis (LPŽ II 25); *Mi k a il u it is : 1619 Mikaiłuitis JNŠ 236v. Dèl mikail- plg. db. pvd. Mikáila, 
Mikáilas, Mikailiónis (LPŽ II 225); *Mi k it u it is : 1621 Mikituitis JNŠ 269v. Dèl mikit- plg. db. pvd. Mikità, Mikitãvičius (LPŽ II 229); *Mykoluitis : 1617 Mikaluitis JNŠ 205. Dèl mykol- plg. db. pvd. Mykoláitis, Mýkolaitis, Mykolaitis (LPŽ II 231); *Mi ku it is : 1620 Mikuitis JNŠ 248v; 1617 Mikujtis JNŠ 202v. Dèl mik- plg. db. pvd. Mikáitis (LPŽ II 225); *M i ku t u i t i s : 1620 Mikutuitis JNŠ 258. Dèl mikut- plg. db. pvd. Mìkutaitis, Mikutáitis (LPŽ II 236); *Motiekuitis : 1620 Motiekuitis JNŠ 249. Dèl motiek- plg. db. pvd. Motiekà, Motiekáitis, Motiẽkus, Motiekúnas (LPŽ II 274); *Paliuluitis: 1619 Palułuitis JNŠ 232. Dèl paliul- plg. db. pvd. Paliulénas, Paliuliónis, Paliùlis, Paliuliû́nas (LPŽ II 382); *Pa u l u i t is : 1620 Pauluitis JNŠ 248. Dèl paul- plg. db. pvd. Pauláitis (LPŽ II 408); *Peč iu lui tis : 1621 Peczuluitis JNŠ 265v(2). Dèl pečiul- plg. db. pvd. Pèčiulaitis, Pečiuláitis, Pečiulaitis (LPŽ II 420); *Pet ra la it is : 1620 Petrałaitis JNŠ 246v. Dèl petral- plg. db. pvd. Petralẽvičius, Petrãlis (LPŽ II 437); *Petrašaitis: 1618 Pietraßajtis JNŠ 219v. Dèl petraš- plg. db. pvd. Petrašẽvičius, Petrašèuskis, Petrašiúnas, Petrãšius (LPŽ II 438); *Petroši ūnaitis: 1620 Petroßunaitis JNŠ 251v. Dèl petrošiūn- plg. db. pvd. Petrošiúnas (LPŽ II 442); *Pocaitis : 1601 Pocaỳtis JNŠ 28. Dèl poc- plg. db. pvd. Pócas, Pocauskas, Pocẽvičius (LPŽ II 482-483); *Ro ma nu it is : 1619 Romannuýc JNŠ 233. Dèl roman- plg. db. pvd. Romanaitis (LPŽ II 619); *Sta n iu luit is: 1619 Staniułuÿc JNŠ 232; 1618 Staniułuytis JNŠ 211v. Dẻl staniul- plg. db. pvd. Staniuláitis (LPŽ II 802); *Sta nk ūna it is : 1620 Stankunaitis JNŠ 254v. Dèl stankūn- plg. db. pvd. Stankúnas, Stankūnãvičius (LPŽ II 804); *Sto ni ūn as : 1601 Stoniuns JNŠ 18. Dèl ston- plg. db. pvd. Stõnis, Stónis, Stonỹs, Stõnius (LPŽ II 826); *Tamošuitis: 1601 Tamoßuitis JNŠ 30v. Dèl tamoš- plg. db. pvd. Tamošáitis (LPŽ II 1016); *Urnieži u it i s: 1621 Vrnezuitis JNŠ 259v. Dèl urniež- plg. db. pvd. Urniẽžis, Urniẽžius (LPŽ II 1113); *Vaitiekuitis : 1619 Vaitekuitif JNŠ 237. Dèl vaitiek- plg. db. pvd. Vaitiekáitis (LPŽ II 1139); *Val a nča it i s : 1617 Wolączaỳtis JNŠ 202. Dèl valanč- plg. db. pvd. Valančáuskas, Valančiónis, Valančis, Valančiúnas, Valañčius (LPŽ II 1146); *Valentinaitis: 1601 Valentinaitis JNŠ 19v. Dèl valentin- plg. db. pvd. Valentinas, Valentinãvičius (LPŽ II 1150); *Va siula it is: 1601 Wasiułaitis JNŠ 28. Dèl vasiul- plg. Vasiuliauskas, Vasiùlis (LPŽ II 1170).

Paaiškèjo, kad 92 (63 \% visu rekonstruotų) atkurti asmenvardžiai vartojami ir šiomis dienomis. Dalis, t. y. 54 (37 \%) turi tos pačios kilmès, tik skirtingos darybos dabartinių pavardžių atitikmenis. Tarp šiuo metu nepaliudytų antroponimų dažni priesagos -(i)uitis vediniai. Ankstesni XVII a. lietuvių istorinių asmenvardžiu tyrimai beveik nėra paliudiję šios priesagos vartosenos. Tačiau manoma, kad priesaga -uitis yra vadintina patronimine priesaga. Tai 
leidžia daryti XVII a. Gruzdžių parapijos antroponimų su priesaga -uitis gausa ir detali jų antroponiminè analizė (Maciejauskienė 2010: 820). Tarp nagrinètų XVI-XVII a. Joniškio miestiečių patroniminès kilmės asmenvardžių priesagos -(i)uitis vediniai sudare 14,60 \% (Ragauskaitė 2019b: 187, 194). Kai kurie straipsnyje analizuoti krikščioniškos kilmès antroponimai yra vertintini kaip grafiniai variantai. Jie galèjo atsirasti nedėsningai dẻl raštininkų neatidumo ar kt. ekstralingvistinių aplinkybių (lietuvių, lenkų ir lotynų kalbų sąveikos).

\section{Išvados}

1. Iš 1599-1621 m. Joniškio parapijos krikšto metrikų knygos buvo atrinkti kaimų gyventojų 556 dvinariai užrašymai. Pirmieji šių dvinarių ịvardijimų nariai - tai krikščioniški vardai. Daugiausia surasta tradicinių krikščioniškų vardų lyčių.

2. Darybinei analizei atrinkti 556 krikščioniškos kilmès asmenvardžiai (antrieji dvinario įvardijimo modelio nariai) buvo suskirstyti ị dvi grupes: 1) antroponimai su lietuviškomis -aitis, -(i)onis, -(i)ūnas, -(i)uitis ir slaviškomis -evič, -ovič patroniminėmis priesagomis, su deminutyvinèmis priesagomis ir 2) asmenvardžiai be šiu priesagų.

3. Pirmoji grupè yra gerokai didesnè. Ją sudaro 552 (99,28\% visų antrųju antroponimų) asmenvardžiai. Tarp jų dažniausi patroniminių priesagų -aitis (359, t. y. $65 \%$ ) vediniai. Antrojoje grupejje tik 4 (0,72\%) antroponimai.

4. Palyginus 146 atkurtų asmenvardžių formas su dabartinėmis lietuvių pavardèmis, nustatyta, kad 92 (63\%) funkcionuoja ir šiandien. Mažesnè dalis, t. y. 54 (37 \% visų atkurtų antroponimų) turi tos pačios kilmès, tik skirtingos darybos dabartinių pavardžių atitikmenis. 


\section{Priedai}

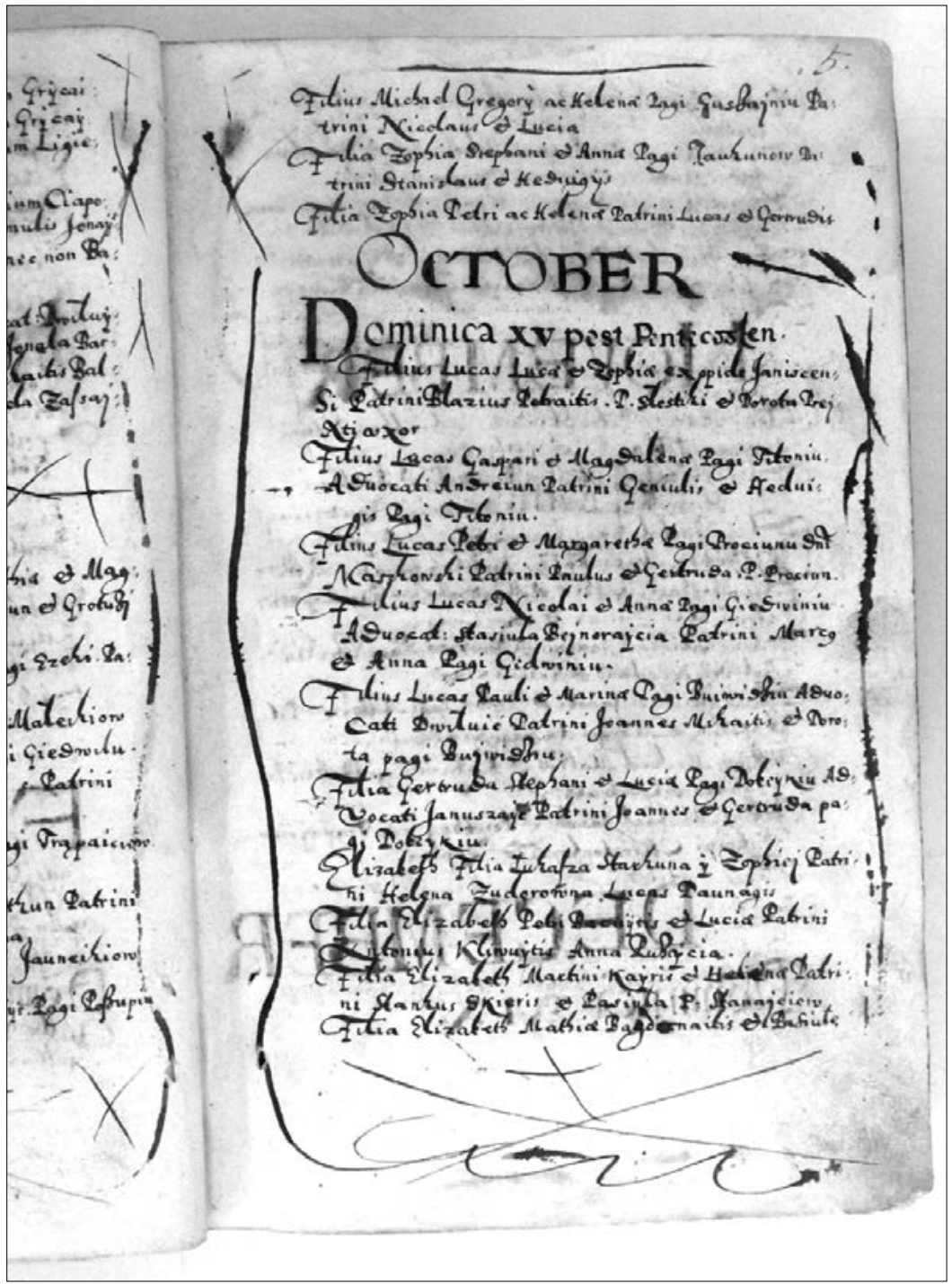

1 pav. $1599 \mathrm{~m}$. fragmentas iš $1599-1621 \mathrm{~m}$. Joniškio parapijos

krikšto metrikų knygos (1. 5) 


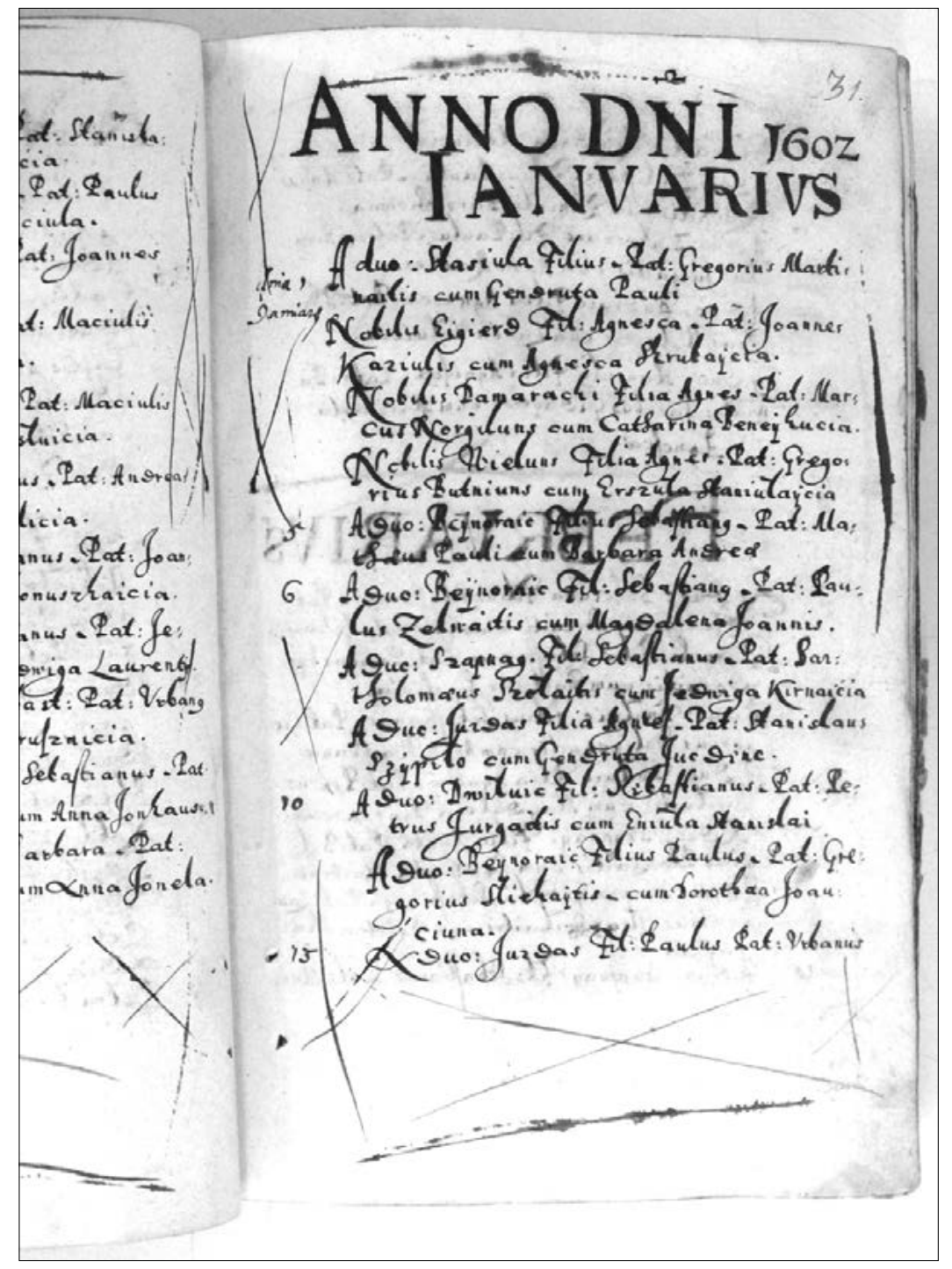

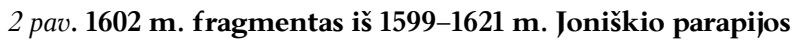
krikšto metrikų knygos (1. 31) 


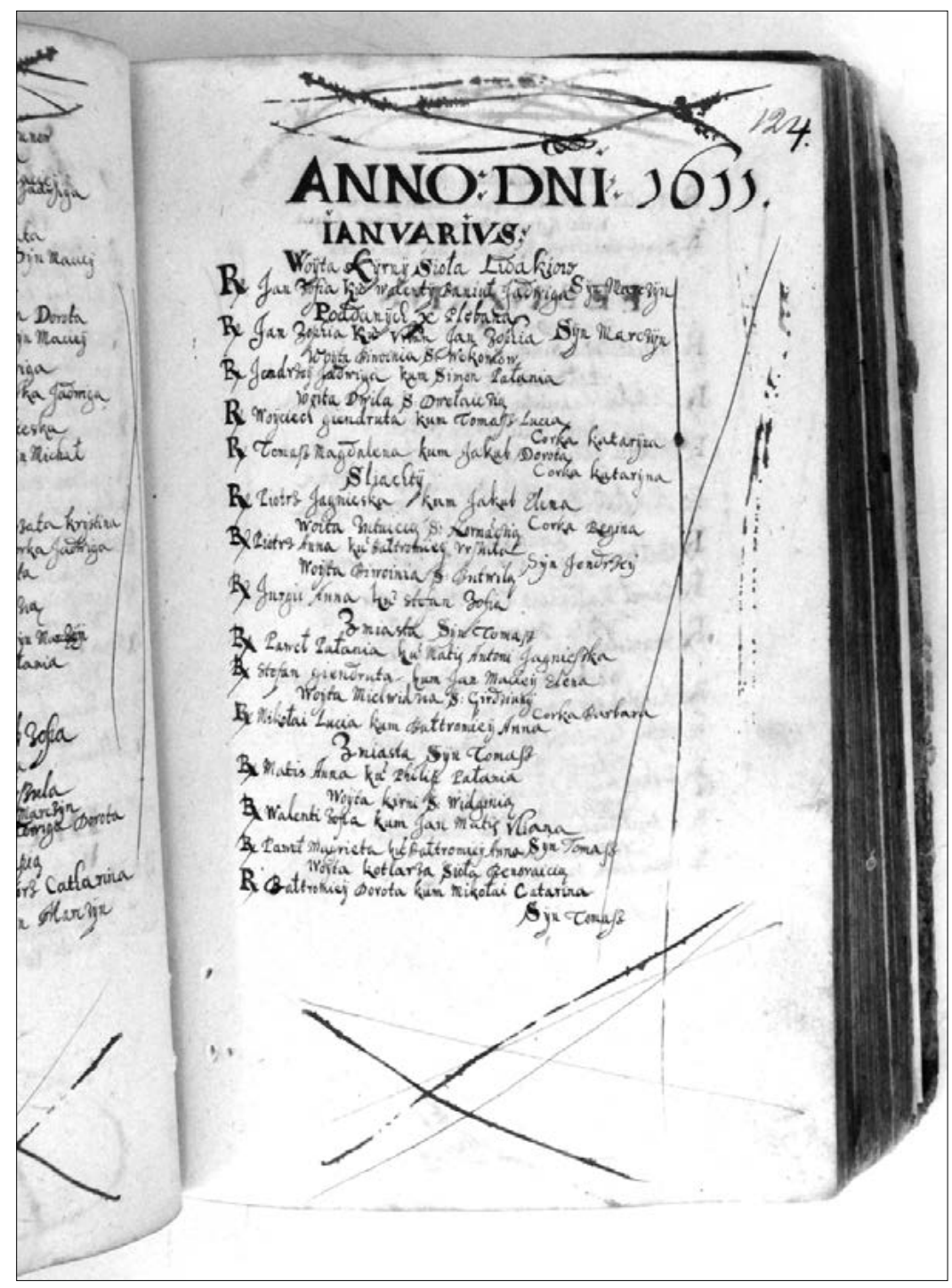

3 pav. $1611 \mathrm{~m}$. fragmentas iš $1599-1621 \mathrm{~m}$. Joniškio parapijos krikšto metrikų knygos (1. 124) 


\section{Sutrumpinimai}

db. - dabartinis, $-\dot{e}$

gen. - lo. (cāsus) genetīvus 'kilmininko linksnis'

plg. - palygink

sg. - lo. (numerus) singulāris 'vienaskaita'

pvd. - pavardè

v. - vardas

\section{Istorijos šaltinis}

Jnš = 1599-1621 m. Joniškio parapijos krikšto metrikų knyga [„Liber Baptisatoru(m) \| Ecc(lesi)æ Parochialis Jani=\|scensis ab Anno 1599. - \| usq(ue) ad An(n)um || 1621. -"]. Lietuvos valstybès istorijos archyvas. F. 1196. Ap. 1. B. 76.

\section{Literatūra}

Garliauskas, Vidas. 1998. Lietuviškos oikonimų lytys nelietuviškuose XVI-XIX a. šaltiniuose. Lietuvių kalbotyros klausimai 40, 123-204.

Garliauskas, Vidas. 2004. XVII a. Molètų bažnyčios krikšto ir santuokos metrikų knyga.

LPŽ I-II =

LVKŽ =

Maciejauskienè, Vitalija. 1977.

Maciejauskienè, Vitalija. 1991.

Maciejauskienè, Vitalija. 1993.

Maciejauskienè, Vitalija. 2010.

Ragauskaitè, Alma. 1999.

Ragauskaité, Alma. 2004.

Ragauskaitè, Alma. 2005.

Ragauskaite, Alma. 2015.

Ragauskaite, Alma. 2018a. Vilnius: Mokslo ir enciklopediju leidybos institutas.

Lietuviu pavardžiu žodynas 1-2, aut. Vitalija Maciejauskienė, Marija Razmukaite, Aleksandras Vanagas, ats. red. Aleksandras Vanagas. Vilnius: Mokslas, 1985-1989.

Lietuviu vardu kilmés žodynas, aut. Kazys Kuzavinis, Bronys Savukynas. Vilnius: Mokslo ir enciklopedijų leidykla, 1994.

Lietuvių asmenvardžių priesagų paplitimas XVII a. Lietuvių kalbotyros klausimai 17, 159-168.

Lietuvių pavardžių susidarymas XIII-XVIII a. Vilnius: Mokslas.

Kriaunų parapijos XVII-XVIII a. asmenvardžiai. Lietuviu kalbotyros klausimai, 32: Baltu onomastikos tyrimai, 34-99.

Gruzdžių pavardès: istorija ir dabartis. Gruzdžiai 2, Vilnius: Versmè, 818-844.

XVI a. II pusès Kauno miestiečiu lietuviškos kilmès asmenvardžiai. Acta Linguistica Lithuanica / Lietuvių kalbotyros klausimai 41, 145-158.

XVI-XVII a. joniškiečių asmenvardžiai. Istoriniai tekstai ir vietos kultūra. Šiauliai, Ryga: Lucilijus, 8-18.

XVI-XVIII a. kauniečių asmenvardžiai. Vilnius: Lietuvių kalbos instituto leidykla.

Seniausios Lietuvoje 1599-1621 metų Joniškio krikšto metrikų knygos joniškiečių moterų asmenvardžiai lietuvių istorinès antroponimijos kontekste. Acta Linguistica Lithuanica 73, 55-81.

XVII a. kèdainiečiu asmenvardžių darybos tendencijos. Baltu filologiija 27, 101-118. 
Ragauskaitè, Alma. 2018b. XVII a. kèdainiečių lietuviškos kilmès asmenvardžiai. Acta Linguistica Lithuanica 78, 53-75.

Ragauskaitè, Alma. 2019a. Lietuviškos kilmès asmenvardžiai seniausioje Lietuvoje 15991621 m. Joniškio krikšto metrikų knygoje. Baltu filologija 28(1), 153-168.

Ragauskaitè, Alma. 2019b. Joniškiečių vyrų asmenvardžių darybos tendencijos seniausioje Lietuvoje 1599-1621 m. Joniškio krikšto metrikų knygoje. Acta Linguistica Lithuanica 80, 177-194.

Vanagas, Aleksandras. 1974. Pavardès iš hebrajiškos kilmès vardų. Žodžiai ir žmonès. Vilnius: Mintis, 86-152.

Vanagas, Aleksandras. 1977. Pavardès iš graikiškos kilmès vardų. Žmonès ir kalba. Vilnius: Mokslas, 48-92.

Vanagas, Aleksandras. 1980. Pavardès iš lotyniškos kilmès vardų. Kalba ir mintis. Vilnius: Mokslas, 52-95.

Vanagas, Aleksandras. 1982. Mūsų vardai ir pavardès. Vilnius: Mokslas, 68-72.

Vanagas, Aleksandras. 1983. Pavardès iš slaviškos kilmès vardų. Mintis ir ženklas. Vilnius: Mokslas, 73-103.

Zinkevičius, Zigmas. 1977a. Lietuvių antroponimika. Vilniaus lietuvių asmenvardžiai XVII a. pradžioje. Vilnius: Mokslas.

Zinkevičius, Zigmas. 1977b. Tẻvavardinè asmenvardžių sistema Lietuvoje. Baltistica. II priedas, 151-156.

Zinkevičius, Zigmas. 2005. Krikščionybès ištakos Lietuvoje. Vilnius: Katalikų akademija.

Zinkevičius, Zigmas. 2007. Senosios Lietuvos valstybès vardynas. Vilnius: Mokslo ir enciklopedijų leidybos institutas.

Zinkevičius, Zigmas. 2008. Lietuvių asmenvardžiai. Vilnius: Lietuvių kalbos institutas.

Zinkevičius, Zigmas. 2010. Krikščioniško vardyno kelione i Lietuvą. Vilnius: Lietuvių kalbos instituto leidykla.

Žilys, Saulius. 2012. Bažnyčių metrikų knygos ir parapijiečių sąrašai Lietuvos mokslų akademijos Vrublevskių bibliotekos Rankraščiu skyriuje: kilmè ir konfesiniai ypatumai. Atminties instituciju rinkiniai. Bibliotheca Lithuana 2. Vilnius: Vilniaus universiteto leidykla, 123-154.

\author{
Alma Ragauskaite \\ Baltu kalbu ir vardyno tyrimu centras \\ Lietuviu kalbos institutas \\ P. Vileišio g. 5, LT-10308 Vilnius, Lietuva \\ alma.ragauskaite@lki.lt \\ ORCID: 0000-0001-5952-8027
}




\title{
KOPSAVILKUMS
}

\section{Kristīgas cilmes personvārdi vecākajā lietuviešu kristību metriku grāmatā Jonišḳos (1599-1621)}

\begin{abstract}
Alma RAGAUSKAITÉ
Draudžu metriku grāmatas ir viens no svarīgākajiem Lietuvas vēsturiskās antroponīmijas izpētes avotiem. Šo reğistru kontekstā izceḷas hronolog̣iski unikāls Jonišksu pilsētas kristību reg̣istrs no 1599. līdz 1621. gadam, kas pašlaik ir vecākais zināmais lietuviešu draudzes reǵistrs Lietuvā. No 556 kristīgas cilmes antroponīmiem, kas analizēti rakstā, 146 gadījumos tika rekonstruētas personvārdu formas (*Andriejūnas, *Baltramiejūnas, *Čepaitis, *Griciūnas, *Jankūnas, *Kasiulis, *Laurynaitis, *Motiejuitis, *Petraitis, *Ramonaitis, *Stanaitis, *Šimaitis, *Tamošaitis, *Vaitiekaitis). Salīdzinot rekonstruētos antroponīmus un mūsdienu Lietuvas uzvārdus, redzams, ka 92 (63 \%) no tiem mūsdienās ir joprojām sastopami. Daḷai no tiem, t. i. 54 (37 \% no visiem rekonstruētajiem antroponīmiem), ir atrodami līdzīgi tās pašas cilmes uzvārdi, taču ar atšksirīgiem formantiem ( ${ }^{*}$ Andruškaitis, ${ }^{*}$ Baniuškuitis, ${ }^{*}$ Gricaitis, ${ }^{*}$ Maciuluitis, *Pečiuluitis, *Romanuitis, ${ }^{*}$ Stankūnaitis, ${ }^{*}$ Tamošuitis, ${ }^{*}$ Urniežiuitis, ${ }^{*}$ Valančaitis).
\end{abstract}

\section{SUMMARY}

\section{Personal Names of Christian Origin in the Oldest Lithuanian Baptismal Register of Joniškis Parish (1599-1621)}

\section{Alma RAGAUSKAITÉ}

Parish registers are among the most important historical documents of Lithuanian historical anthroponymy. A chronologically unique baptismal register of Joniškis parish dating from 1599-1621, which is currently the oldest known Lithuanian parish register in Lithuania, stands out in the context of such registers. Out of 556 anthroponyms of Christian origin analysed in the article, 146 personal names with Lithuanian suffixes were reconstructed (*Andriejūnas, *Baltramiejūnas, *Čepaitis, *Griciūnas, *Jankūnas, *Kasiulis, *Laurynaitis, *Motiejuitis, *Petraitis, *Ramonaitis, ${ }^{*}$ Stanaitis, ${ }^{*}$ Šmaitis, ${ }^{*}$ Tamošaitis, ${ }^{*}$ Vaitiekaitis). A comparison of the reconstructed anthroponyms and present-day Lithuanian surnames shows that $92(63 \%)$ of them still occur today. Some of them, i. e. 54 (37\% of all reconstructed anthroponyms), have equivalent surnames of the same origin but different formation ( ${ }^{*}$ Andruškaitis, ${ }^{*}$ Baniuškuitis, ${ }^{*}$ Gricaitis, *Maciuluitis, ${ }^{*}$ Pečiuluitis, ${ }^{*}$ Romanuitis, ${ }^{*}$ Stankūnaitis, ${ }^{*}$ Tamošuitis, ${ }^{*}$ Urniežiuitis, ${ }^{*}$ Valančaitis). 


\section{A CASE OF TEACHING MODERN LATVIAN}

\section{Ërika SAUSVERDE \\ Vilnius University}

To learn the new words was one thing, to learn their meanings was another. It sounds maybe a bit paradoxical, but it is easy. One learns the words first as names and that takes nothing but a good memory. But these names are not neutral, they are covered by the centuries of lava of human knowledge, feelings, experiences and values. To learn a new language becomes in that way a pervasive travel into a different understanding of the world and life itself.

\section{Theodor Kallifatides}

In December 1986 after finishing PhD studies in historical linguistics in St. Petersburg I started to work at Vilnius University. To my surprise my main task became the teaching of Latvian to numerous students studying Lithuanian Philology as their main subject. Not Swedish or Gothic or other old Germanic Languages - my specialization, but my mother tongue. Simultaneously I myself was strenuously learning Lithuanian - the thought that in a month I should deliver a course on Old Germanic Languages in Lithuanian, about which I then knew so little, spurred me on as nothing else $-\mathrm{a}$ few classes of Lithuanian which I attended in St. Petersburg when we took our time reading some weird and wonderful Lithuanian fairy tales were left far behind - in a month I should tell students in Lithuanian about peripeteias of visi- and ostrogoths, Codex Argenteus, runic inscriptions etc. ${ }^{1}$ Maybe it was a blessing that I was not then acquainted with the modern methodology of language teaching, and was groping my way, choosing instinctively, feeling on a hunch which way of learning and teaching would be the best. I was glad at least to realize which way of learning and teaching I did not like and could reject methods and sources which I would not like to use learning languages myself. Curiously enough, my knowledge of Lithuanian structure was based on 11 chapters of Alfred Senn's book Kleine Litauische Sprachlehre, published in Heidelberg in 1929, kindly lent to me by my advisor prof. Leonard Herzenberg. My first two sentences in Lithuanian

1 The difference between these two live Baltic Languages is much greater than, e.g., between the Scandinavian ones which have stayed close to each other (by which I mean Swedish, Norwegian and Danish) - the structure of Lithuanian and Latvian is very similar and it is possible to recognize much of vocabulary, but the difference is too great to comprehend one other, hence you must learn. To some extent, the difference could be compared to that of Swedish and German. 
which I coincidentally read in Senn's book when I opened it for the first time were: Alus yra skanus (,Beer is tasty') and Lietuvos prezidentas gyventu Vilniuje, jeigu tas miestas nebütų lenku ('the President of Lithuania would have lived in Vilnius, if that city had not been Polish')2. Those phrases captured my heart, plus I simply liked the structure of the book, the clear exposition of grammar, which I prefered to the then popular and available textbook of Lithuanian. With regard lexicon I simply tried to write the texts of my lectures (including jokes) and learned them by heart (I can just imagine how students were entertained listening to me). Similarly I was searching for my own method of teaching languages. I did not like the textbooks published on either side of the Iron Curtain that were then available - it wasn't the ideology that was a barrier for me, but the "woodenness" of their language.

No method of teaching languages is bad or "not modern" if it works. A brief history of language teaching shows that many new ideas are revised old ones and are not particulary new, as demonstrated by Kelly (1969), Howatt (1984) and others. According to Richards and Rodgers (1986: 1), today's controversies reflect contemporary responses to questions that have been asked often throughout the history of language teaching. As indicateded by Eloeva, numerous reviews of the subject (even the most brief ones) show that, in spite of the impressive diversity of methods and approaches to language teaching, certain basic ideas about the specifics of connection and interplay between language and cognition, language and mind are repeated, reinterpreted, rejected and used again on theoretical as well as empirical levels (this being true since the 19th century) (Eloeva 2009). A detailed analysis of the different methods can be found in Richards and Rodgers (1986). This gives an excellent detailed account of major twentieth-century trends in language teaching. If we were to make a brief summary of some more popular teaching methods, one of the most well-liked in XX century was The Direct Method, which refers to the most widely known of natural methods. In practice it stood for the following principles and procedures:

1. Classroom instruction was conducted exclusively in the target language.

2. Only everyday vocabulary and sentences were taught.

3. Oral communication skills were built up in a carefully graded progression organized around question-and-answer exchanges between teachers and students in small, intensive classes.

4. Grammar was taught inductively.

5. New teaching points were introduced orally.

2 That phrase of course could not be pronounced out loud in those Soviet times as one could easily find oneself in prison. 
6. Concrete vocabulary was taught through demonstration, objects, and pictures; abstract vocabulary was taught by association of ideas.

7. Both speech and listening comprehension were taught.

8. Correct pronunciation and grammar were emphasized.

(Richards and Rodgers 1986: 9-10)

These principles are seen in the following guidelines for teaching oral language, which were followed in Berlitz schools:

Never translate: demonstrate

Never explain: act

Never make a speech: ask questions

Never imitate mistakes: correct

Never speak with single words: use sentences

Never speak too much: make students speak much

Never use the book: use your lesson plan

Never jump around: follow your plan

Never go too fast: keep the pace of the student

Never speak too slowly: speak normally

Never speak too quickly: speak naturally

Never speak too loudly: speak naturally

Never be impatient: take it easy

(Titone 1968: 100-101, cited in Richards and Rodgers 1986: 9-10)

The Direct Method was quite successful in private language schools, but was gradually modified into versions that combined some Direct Method techniques with more controlled grammar-based activities (Ibid: 11).

The other popular language teaching methodologies include such methods as e.g. Grammar-translation; Audio-lingual; The structural approach; Total Physical Response (TPR); Communicative language teaching (CLT); The Silent Way; Community Language Learning; Immersion; Task-based language learning; The Natural Approach; The Lexical Syllabus and so forth (see e.g. Richards and Rodgers 1986, where particular language teaching methods and philosophies are discussed and analysed).

As Richards and Rodgers precisely notice, the survey of language methods raised the questions that prompted innovations and new directions in language teaching in the past, but they are still relevant nowadays:

1. What should the goals of language teaching be?

2. Should a language course try to teach conversational proficiency, reading, translation, or some other skill?

3. What is the basic nature of language, and how will this affect teaching method? 
4. What are the principles for the selection of language content in language teaching?

5. What principles of organization, sequencing, and presentation best facilitate learning?

6. What should the role of the native language be?

7. What processes do learners use in mastering a language, and can these be incorporated into a method?

8. What teaching techniques and activities work best and under what circumstances? (Ibid: 12).

Today in the 21st century so-called communicative language teaching (CLT) has become a buzzword in discussions of the practice and theory of second and foreign language teaching (see Savignon 2007). Though CLT can be seen to derive from a multidisciplinary perspective that includes, at least, linguistics, psychology, philosophy, sociology, and educational research (Ibid: 209) and to incorporate dialogue in all possible meanings as one of its fundamentals (Bakhtin's Dialogue of cultures included), it seems there is a big gap between CLT as an approach and its implementation. Nowadays the world is filled with numerous textbooks based on the principles of the CLT approach full with plenty of dialogues like "at the station", "at the post office" and so forth with plain and primitive texts where a normal developed person just loses his/her identity (of course, there are exceptions). What is the main thing you actually need when you want to send a parcel? - Money. You can be tired and hardly mumble a word, but if you have money you will manage it. But if you approach, for example, a lady in the post-office e. g. in Greece speaking in the language of Kavafis and Seferis you have a chance to send the parcel even without money. ${ }^{3}$ In this context the understanding of Bakhtin's idea of the dialogicity of speech does not dissappear, but still I agree with idea that dialogue should be born within the free communication of learners who are taught to produce a monologue (Eloeva 2009).

Recognition of the complexity and diversity of language learning contexts has led some to suggest that we have moved 'beyond methods' to a postmethod condition (Kumaravadivelu 2002, cited in Savignon, 2007: 218). Nowadays armed by different kinds of knowledge about language teaching looking back at the dawn of my activity I can formulate that my instinctively chosen method was based on mixed principles from different methodologies, including AudioLingual and others. The materials I used were "just" good texts. In the case of the Latvian course for beginners these comprised plenty of poetry - mostly

3 This example is from Prof. Fatima Eloeva, whose teaching methods show extraordinary results with regard language aquisition over a relatively short time. 


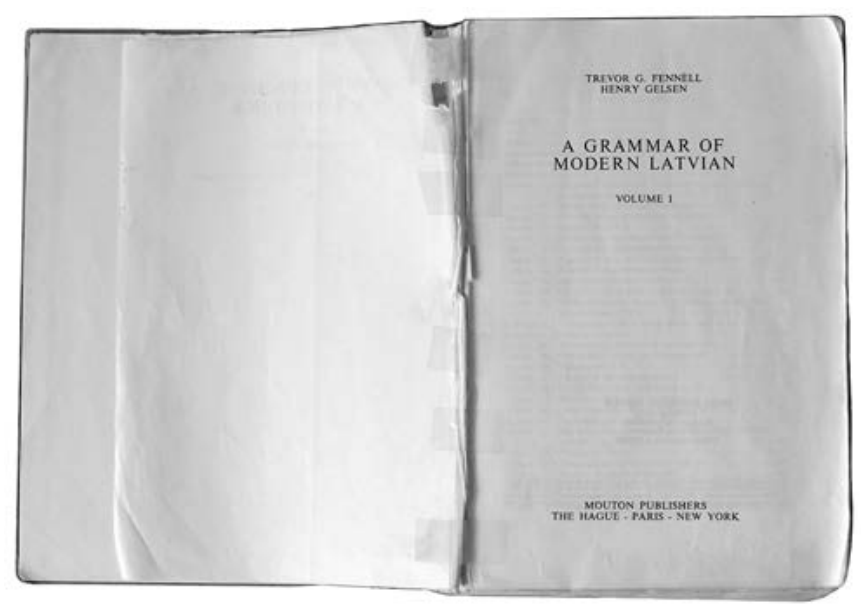

Figure 1. The copy of the book A Grammar of Modern Latvian by Trevor G. Fennell and Henry Gelsen (1980) used as a class manual for more than 20 years

wonderful children's poetry by Jānis Baltvilks - and other hitherto unadopted texts, whether in the original, such as Latvian fairy tales, or translations, e.g. Winnie the Pooh. ${ }^{4}$ I was happy to find at the University Library A Grammar of Modern Latvian by Trevor G. Fennell and Henry Gelsen (1980). I liked its approach - the clear exposition of grammar with hundreds of drills to translate. ${ }^{5}$ Such a method, i.e. of constructing lectures around good texts along with plenty of oral (grammar) drills ${ }^{6}$, I also successfully used in my Swedish classes, where the intensity of the course allowed us to rather rapidly move to the marvellous poetry of Tomas Tranströmer and related discussions. ${ }^{7}$ I completely agree with the idea that such a method concentrates on helping the learner to move rather speedily from the phase of interlanguage to the target language or in the ideal case (using certain mnemonic techniques) to avoid the phase of interlanguage.

4 A. A. Milne's Winnie the Pooh in a wonderful translation of Vizma Belševica in Latvia has become folklore - it is often quoted by people (some years ago I heard it three times during one week - by 2 politicians and a basket coach).

5 When meeting former students years later they still quote me Mums ir vins pagrabā ("We have wine in the cellar" - one of thousand sentences/drills in Fennell/Gelsen's book) along with numerous poems.

6 Of course, accompanied by hundreds of different sources and techniques.

7 It was fascinating to hear that the well known Swedish writer Theodor Kallifatides, who came to Sweden at the age of 25, learned Swedish reading August Strindberg. 


\section{References}

Eloeva, Fatima. 2009. Language teaching - monologue or dialogue? Proceedings of 9th International Conference on Greek Linguistics. 29 October 2009-31 October 2009 Chicago, Illinois, USA.

Fennell, Trevor G., Henry Gelsen. 1980.

A Grammar of Modern Latvian. Volumes 1-3. De Gruyter Mouton.

Howatt, Anthony P. R. 1984.

Kelly, Louis G. 1969.

A History of English Language Teaching. Oxford: Oxford University Press.

25 Centuries of Language Teaching; an inquiry into the science, art, and development of language teaching methodology, 500 B.C.1969. Rowley, Mass.: Newbury House Publishers.

Kumaravadivelu, B. 2002. Beyond Methods: Macrostrategies for Language Teaching. New Haven and London: Yale University Press.

Richards, Jack C., Theodore

S. Rodgers. 1986.

Approaches and Methods in Language Teaching. A description and analyses. Cambridge Language Teaching Library. Cambridge: Cambridge University Press.

Savignon, Sandra J. 2007. Beyond communicative language teaching: What's ahead? Journal of Pragmatics 39 (2007). 207-220.

Titone, Renzo. 1968.

Teaching Foreign Languages: An Historical Sketch. Washington, D.C.: Georgetown University Press.

Ërika Sausverde

Skandinavistikos centras

Filologijos fakultetas

Vilniaus Universitetas

Universiteto g. 5, LT-01513 Vilnius, Lietuva

erika.sausverde@flf.vu.lt

\section{KOPSAVILKUMS}

\section{Mūsdienu latviešu valodas mācǐšanas gadījums}

\section{Ērika SAUSVERDE}

Neskaitāmi valodu mācību tēmas pārskati liecina, ka, neraugoties uz metožu un pieeju iespaidīgo daudzveidību, dažas pamatidejas tiek daudzkārt atkārtotas un interpretētas. Valodu apguves kontekstu sarežğìitîbas un daudzveidības atzǐšana dažiem autoriem liek domāt, ka esam nonākuši līdz „postmetodes“ stāvoklim (Kumaravadivelu 2002; Savignon 2007). Šksiet, ka pastāv liela atškirīiba starp CLT (komunikatīvā valodas mācīšana - viena no populārākajām metodēm mūsdienās) kā pieeju un tās īstenošanu. Šajā rakstā tiek uzskatīts, ka dialogam, kas ir viens no CLT pamatiem, vajadzētu veidoties brīvā saziņā starp izglītojamajiem, kuriem māca veidot monologu. Lekciju konstruēšana ap labiem tekstiem kopā ar daudziem (gramatikas) vingrinājumiem ir metode, kas var palīdzēt izglītojamajam diezgan ātri pāriet no starpvalodas fāzes uz mērḳvalodu. 


\title{
LATVIEŠU PERSONVĀRDI AR -IT UN -ULL 17. GADSIMTĀ
}

\author{
Renāte SILIN̦A-PIN̦ĶE \\ Latvijas Universitäte
}

\section{Ievads}

Raksta virsrakstā formulētā tēma ir dalıa no plašāka pētījuma par latviešu

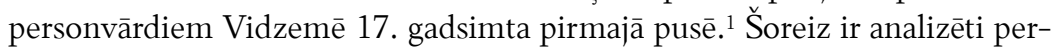
sonvārdi ar formantiem -it un -ull un to rakstības varianti.

Atbilstošie mūsdienu latviešu valodas piedēkḷi - $\bar{l} t-$ un -ul- jaunākajā akadēmiskajā „Latviešu valodas gramatikā“" saistībā ar antroponīmiem ir pieminēti tikai deminutīvu un sarunvalodā lietotu hipokoristiku funkcijā (Vulāne 233: 242), bet attiecībā uz senākiem personvārdiem šis jautājums vēl ir pētāms. ${ }^{2}$ Tas arī tika izvirzīts par mērķi šajā rakstā. Lai to sasniegtu, ir izvērtēts apjomīgais latviešu personvārdu materiāls 1638. gada zviedru arklu revīzijas protokolos Vidzemē un salīdzināts ar 17. un 18. gadsimta vārdnīcu dotumiem.

Pirms iedziḷināšanās 17. un 18. gadsimta latviešu personvārdu raibajā daudzveidībā tika noskaidrota piedēkḷu vai škietamu piedēkḷu -ît- un -ulizplatîba mūsdienu personvārdos. Šim mērkim tika izmantoti 2020. gada kalendārā ieklạutie personvārdi. No 1013 kalendārvārdiem vismaz formāli ar šādām izskaņām saistāmi bija 22 vārdi, kas ir nedaudz vairāk nekā 2 \% no visiem kalendārvārdiem, turklāt lielākā to daḷa (19 vārdi) ir sieviešu personvārdi ar izskaņu (vai tikai šksietamu izskaņu) -īte: Dainuvīte, Dzirkstīte, Edīte, Gudrīte, Jautrīte, Judīte, Mārīte, Modrīte, Mudìte, Mudrīte, Rudīte, Sarmīte, Saulcerìte, Skaidrīte, Vijolīte, Vizbulīte, Zeltīte, Ziedīte un Žubīte. Atlikušie trīs ir vīriešu vārdi Andulis, Bērtulis un Indulis. Lielākā daḷa sieviešu vārdu ir latviskas cilmes, ko nevar teikt par vīriešu vārdiem, bet latviskas cilmes nav arī vārdi Edīte, Judīte un, iespējams, Mārīte. ${ }^{3}$ Trim vārdiem - Bērtulis,

1 Sal. arī rakstus Siliņa-Piṇke (2005, 2014a, 2014b).

2 Vēl izteiktāk tas senajos tekstos attiecināms uz formantu -ing, proti, iespējamo piedēkli -iñ-, kas apjomīgāka personvārdu materiāla dẹḷ analizējams atsevišḳā rakstā. Līdz šim pētījumi ir veikti tikai par senākajiem latviešu uzvārdiem, kas darināti no latviešu valodas apelatīviem (sal. Blese 1929: 78-80, 91). Arī lietuviešu vēsturiskajā antroponomastikā šie piedēkḷi ir skarti (gan tikai nedaudz) tieši uzvārdu darināšanas kontekstā (piemēram, Ragauskaitė 2019: 181; Sinkevičiūtè 2006: 116-118).

3 Vairāk par deminutīviem patstāvīgu personvārdu funkcijā mūsdienās, par to darināšanas modeliiem, rašanās laiku un izplatību mūsdienās skat. Balode (2018). Autore arī secina, ka „deminutīvu personvārdu lietojums pagātnē, to izplatība dažādos Latvijas reǵionos un Baznīcas ietekme to izvēlē ir vēl nākotnē pētāmi jautājumi“ (Balode 2018: 200). 
Edìte un Judīte - vispār nevar runāt par izskaņu, bet tikai par svešas cilmes vārdu pielāgošanu latviešu valodas izrunai un formālu sakritību ar latviešu izskaņām. Lielākā dą̧a šo personvārdu latviešu antroponīmiskajā sistēmā ir ienākuši tikai 19. un 20. gadsimtā (sal. Balode 2018: 198-200), tāpēc liela līdzība ar 17. gadsimta personvārdiem nebija sagaidāma.

\section{1638. gada revīzijas dati}

17. gadsimta personvārdu materiāla apzināšanai no Vidzemes 1638. gada zviedru arklu revīzijas ${ }^{4}$ tika ekscerpēti visi personvārdi, kuri formāli atbilda sākumā noteiktajiem kritērijiem, t. i., beidzās ar -it un -ull, vai to rakstības varianti. No kopumā 825 revīzijas materiālā sastopamajām personvārdu formām šādas bija 16 (t. i., apmēram 1,9 \%). Savukārt, ja paskatās uz revīzijā pieminēto personu skaitu, tad no 12150 minētajiem zemniekiem šādi ir pierakstītas 25 personas (t. i., apmēram 0,2 \%). 13 personu desmit vārdi beidzas ar -it(t), -its, -itz un 12 personu seši vārdi beidzas ar -ull vai -uls. Tātad gan šādu vārdu skaits, gan to lietojuma biežums ir samērā niecīgi.

Būtiski bija arī noskaidrot, vai kādas komisijas rakstvedis nav īpaši aizrāvies ar latvisku izskaņu pierakstīšanu vai varbūt ar to pilnīgu ignorēšanu. Izrēķinot šādu vārdu procentuālo dạlu no visiem katrā revīzijas komisijā pierakstītajiem vārdiem, jāsecina, ka to īpatsvars ir neliels. Piecas komisijas (1., 5., 6., 7. un 10. komisija) ar mazākajiem revidēšanas apgabaliem un salīdzinoši nelielāku revidēto personu skaitu šādus vārdus nav pierakstījušas. Pārējās piecās komisijās to biežums svārstās robežās no 0,03 līdz 0,75 \%. Visvairāk to ir astotās komisijas protokolā, kurš arī citādi izceḷas ar lielu personvārdu formu daudzveidību.

Jāuzsver gan, ka šajā materiāla apzināšanas stadijā kā atsevišķi vārdi ir skaitīti visi rakstības varianti un vēl nav pievērsta uzmanība attiecīgo vārdu formām citās, pārsvarā vācu, valodās.

\section{Formants $-u l$}

Kā pirmais personvārds (pēc alfabētiska uzskaitījuma) šajā nodaḷā ir atzīmējams 2020. gada kalendārā sastopamais (un ievadā minētais) vārds Andulis, jo seši vārdi ar -ull 1638. gada revīzijas materiālā ir Andull (5 personas), Jackull (1), Janull (1), Mattuls (1), Michuls (1) un Mickull (3), kas, visticamāk (bet ne piln̄̄gi droši), ir latviešu valodā darināti atvasinājumi no

4 Vairāk par pašu revīziju skat. Edgara Dunsdorfa ievadu revīzijas edīcijai (Dunsdorfs 1938), attiecībā uz antroponīmu materiālu tajā skat. arī Siliņa-Piņķe (2005: 143-145; 2014a). 
revīzijas protokolos krietni biežāk fiksētajiem vārdiem Andress, Jakobs (t. i., no īsformas Jaks vai Jāks), Jānis, Matīss (vai no īsformas Mats) un Mik̨elis (vai no īsformas Miks) vai, kas šķiet mazāk ticami, no krievu vārda Mikola (< Nikolajs). ${ }^{5}$ Klāva Siliņa „Latviešu personvārdu vārdnīcā“ ir ietverti tikai trīs no šiem pieciem vārdiem, kaut gan autors revīzijas materiālu ir izmantojis un uz to atsaucas. Tie ir Andulis (pirmminējuma gads 1562), Matuls (1638) un Mikuls (1638) (Siliņš 1990: 57, 234, 239). ${ }^{6}$

Zīmīgi, ka revīzijas materiālā trūkst vārda Bērtulis. Savukārt Georga Manceḷa vārdnīcas „Lettus“ sarunu dạ̧ā kā vienīgais personvārds ar formantu -ul- ir lietots tieši Bērtulis, proti, Bährtuls, un kā vācu atbilsme dots vārds Barthold (Mancelius 1638: 415).

Ieskatoties jau plašākajos un pusotru gadsimtu jaunākos Gotharda Frīdriha Stendera vārdnīcas „Lettisches Lexikon“ personvārdu sarakstos, šādu vārdu ir vairāk. Pirmkārt, tie ir sieviešu vārdi (revīzijā sieviešu vārdi nav fiksēti) - Bahrbule un, domājams, arī Auduḷ - un vīriešu vārdi Behrtuls, Induls, Pahwuls un Sahmuls. G. F. Stenders tos dod kā vācu personvārdu Barbara, Adelheit, Bartholomäus vai/un Barthold ${ }^{7}$, Heinrich, Paul un Samuel latviešu atbilsmes (Stender 1789: II 375, 376). ${ }^{8}$ Kā redzams, no 17. gadsimta materiāla atkārtojas tikai vārds Bērtuls.

Dīvaino faktu par Bērtuḷa vārda trūkumu 1638. gada revīiijā var izskaidrot ar citu, vācu valodai tuvāku formu, piemēram, $\operatorname{Bert}(t) e l(l)$ rakstību, tomēr arī formas ar -ul 17. gadsimta pirmās puses dokumentos ir izdevies atrast. Tās ir tā paša laika dokumentos divreiz fiksētās formas Bertul un Bertull (vairāk par to skat. Siliņa-Piņķ̧ 2013: 221). Savukārt mūsdienās zināmā vārda Andulis trūkumu 17. un 18. gadsimta vārdnīcās, iespējams, var mēg̣ināt skaidrot ar tā reǵionālu izplatību. 1638. gada revīzijā visas piecas šajā vārdā nosauktās personas ir reǵistrējis devītās komisijas rakstvedis Bērzaunes mācìtājmuižā un Cesvaines muižas Kujas vakā (VAR III 1118, 1182, 1183). Arī K. Siliņa vārdnīcā šī vārda pirmminējums ir fiksēts Mārcienā (Siliņš 1990: 57), tātad visi minējumi lokalizējami dienvidaustrumu Vidzemē, sēlisko izlokšņu areālā.

5 Par vārda Jānis izplatību revīzijas materiālā skat. Siliņa-Piņķe (2005), par vārdu Jakobs, Andress, Matīss un Miķelis - Siliņa-Piņķe (2014a: 185-192).

6 K. Siliņš tos piesardzịgi (pievienojot jautājuma zīmi) saista ar vārdiem Andrejs, Mateuss un Nikolajs.

7 Par šo dubulto atbilsmi vairāk skat. Siliṇa-Pinke (2013: 221-222). Iespējams, ka G. F. Stenderam tā ieviesta, nevēloties ignorēt $\mathrm{G}$. Manceḷa doto atbilsmi.

8 Šīs pašas atbilsmes atkārto arī Karls Kristians Ulmanis, atškirīịi ir pierakstīti vārdi Andula, Behrtulis un Indulis (Ulmann 1872: 351, 352; Ulmann, Brasche 1880: 797, 798). Par vārdu Indulis senāku gadsimtu avotos skat. Siliņa-Piņķe (2016: 242-243). 
Neiedzilinoties visu atrasto personvārdu visos iespējamajos cilmju un aizgūšanas ceḷu izklāstos (kas nav šì raksta uzdevums), apkopotais materiāls lauj izteikt dažus novērojumus.

1. 17. gadsimta Vidzemes latviešu personvārdu materiālā dominē aizgūtu personvārdu latviskotu īsformu atvasinājumi ar latviešu piedēkli -ul-, piemēram, vācu Andres, Jacob > latv. īsformas *And(r)is, *Jaks (vai ${ }^{*}(\bar{a} k s)^{9}>$ latv. Andulis, Jakulis (vai Jākulis), vai aizgūtu personvārdu (arī aizgūtu īsformu) atvasinājumi, piemēram, vācu Andres, Matz u. tml. $>$ latv. ${ }^{*}$ And(r)ulis (> Andulis?), Matulis. ${ }^{10}$ Starpposmi var būt dažādi, bet tie pieejamā materiālā ir tikai hipotētiski restaurējami. Vienīgais izņēmums šajā ziņā ir vārds Bērtulis (skat. nākamajā punktā).

2. Savukārt G. F. Stendera materiāls rāda formantu -ul- kā adaptācijas instrumentu aizgūtu vārdu latviskošanā, turklāt vairumā gadījumu var novērot procesu, kad citvalodu vārda izskaņa -el (ko gan Stenders savās vācu atbilsmēs nesniedz) pārveidota par $-u l(i) s$, piemēram, Bertel > Bērtulis, Pawel > Pāvuls, Barbel > Bārbule (atbilstošos vēsturiski fiksētos vācu personvārdus sal. HdV I 244-245, 292-293, HdV III 496-497, 500-501). Vārds Sāmulis ir radies, likvidējot hiātu vārdā Samuels.

3. Tikpat kā nelatviskotajā 1638. gada revīzijas materiālā, kā arī baznīcu grāmatās nereti ir fiksētas tieši formas ar -el, nevis -ul, sal. 1638. gadā Bertel, Pawel, ${ }^{11}$ bet Ilgas Jansones analizētajā 18. gadsimta Ērğemes draudzes materiālā ir tādi vārdi kā Behrtel un Behrtul, Gromel un Grohmul, Mangel(s), Mangal un Mangul (Jansone 2015: 285, 287). Iespējams, ka formantu -ul-dažos latviešu personvārdos ir ietekmējuši arī vācu personvārdi ar elementu -old. Šeit vietā vēlreiz atgādināt G. Manceḷa doto latviešu-vācu atbilsmi Bērtulis un Barthold.

4. Līdz mūsdienu kalendāram ir izdzīvojuši abu šo personvārdu darināšanas veidu pārstāvji: Andulis, Indulis un Bērtulis. ${ }^{12}$

${ }^{9}$ Sal. vārdus Jack (28 personas), Jacke (2), Jackes (1), Jacks (4) 1638. gada revīzijā.

10 Šeit ieklaujas arī Kristofora Fīrekera vārdnīcas manuskripta komentāros pieminētā forma Inguls (sal. LVVV s.v. Inguls).

${ }^{11}$ Iespējams, šis process ietekmējis arī vārda Mikulis rašanos, sal. 1638. g.: Michel, Mikel u. c. tml. formas.

12 K. K. Ulmaņa vārdnīcas sniedz liecības par vēl dažiem 19. gadsimta personvārdiem vai to izlokšņu formām un atbilstošajiem vācu vārdiem: latv. Grohmulis - vc. Hieronymus, Mahgule - Margarethe un Sapuls - Sophie (Ulmann 1872: 351, 352; Ulmann, Brasche 1880: 797, 798), kā arī Retuls - Reinhold, Ahrfule - Ursula (Ulmann, Brasche 1880: 799). 


\section{Formants -it}

Atškirīga aina ir attiecībā uz formantu -it. Desmit vārdu formas, kas beidzas ar -it(t), -its un -itz, ir saistāmas ar sešiem personvārdiem, proti, Brencis - Brentsit (1), Ansis - Hansit (1), Jānis - Janit (2), Janits (1), Josts Joostit(t) (2), Juris - Jurritz (2) un Laurs - Laurit(z) (3), Lawritz (1). Lai gan ne visu komisiju rakstveži ir pierakstījuši bērnus un ne visiem pierakstītajiem bērniem ir minēts vecums, tomēr tieši šajā grupā vairāk nekā puse - septiņas no 13 personām - ir ietilpināmas bērnu kategorijā - tām minēts vecums no pusgada līdz septiniem gadiem. Trīs personas ir ,juridiski bērni“, t. i., revīzijas rakstveži tos ir iekḷāvuši bērnu kategorijā. Tie ir 16, 18 un 19 gadus veci saimnieku dēli. Savukārt Hansit un Laurit ir pieauguši vīrieši, sētu saimnieki. Interesants ir vārds Joostit - tas pierakstīts tēvam un tā 16 gadus vecajam dēlam Lielvārdes muižā, kas ir ienācēji no Kurzemes, - Joostitt Kaerkell, Auß Cuhrlandt [..] hat 1 Sohn heißet Joostit (VAR III 1009). Tātad abi vienīgie š̄̄ vārda īpašnieki Vidzemē 1638. gadā ir divi kurzemnieki.

G. Manceḷa „Desmit sarunās“ vien̄̄gais personvārds ar šādu izskaņu ir Miḳelītis - uzruna personai vārdā Miķelis: Ko tad darries / labbs Mickeliet / jo Kunghi nhe ghribb paliedfeht. Šis vārds arī vāciskajā versijā ir rakstīts kā deminutīvs ar vācu deminutīva piedēkli -chen: Was fol man denn thun/gutes Michelchen/ die Herrchafft wil ja nicht helffen (Mancelius 1638: 464) (sal. arī Frīdenberga 2014: 84).

Savukārt G. F. Stendera vārdnīcā personvārdi ar šādu izskaņu nav ietverti, bet ir atrodamas visas to neatvasinātās pamatformas: Brenzis, Ans un Ansis, Jahnis un Jannis, Johsts, Jurris, Lauris (Stender 1789: II 375). ${ }^{13}$ Arī I. Jansones analizētajā 18. gadsimta Ērǵemes personvārdu materiālā vārdi ar šādu formantu nav fiksēti.

Pieejamais materiāls liek domāt, ka piedēklis -īt-, iespējams, izmantots tikai jau esošu latviskotu personvārdu atvasināšanai, bet ne personvārdu latviskošanai. Iespējams, tam arī iepriekšējos gadsimtos dominējošā patiešām ir bijusi deminutīva funkcija. Vārdus, kur -it būtu saknes daḷa (sal. mūsdienu Edìte, Judīte), senajā materiālā fiksēt neizdevās.

\section{Nobeigums}

Galvenie secinājumi par rakstā analizēto piedēkḷu vai škietamo piedēkḷu lietojumu 17. (un daļēeji arī 18.) gadsimtā ir apkopoti katras nodą̧as noslēgumā. Tā kā to lietojums izrādīịās atškirīịgs un daudzveidīgs, kopīgas tendences

${ }^{13}$ G. Mancelim no šiem ir fiksēti vārdi Anffis un Brentzis (Mancelius 1638: 436, 460). 
iezīmēt nav iespējams. Kvalitatīvi pierakstīta latviešu personvārdu materiāla trūkums lielāko daliu secinājumu diemžēl atstāj piel̦āvumu un pieņēmumu formā.

Iespējams, kādus kopīgus secinājumus varētu izdarīt pēc personvārdu ar formantu -in un -ing analīzes 17. un 18. gadsimta avotos, kas varētu būt viens no turpmākajiem pētniecības uzdevumiem, jo 1638. gada revīzijas materiālā sastopami paralēli atvasinājumi, piemēram, gan Juriņš un Jurīts, gan Lauringš un Laurīts, un attiecībā uz latviešu uzvārdiem šādas paralēlas formas novērojis jau Ernests Blese (1929: 73).

\section{Literatūra}

Balode, Laimute. 2018. Deminutīvi patstāvīgu personvārdu funkcijā. Onomastica Lettica 5. Rīga: LU Latviešu valodas institūts, 195-209.

Blese, Ernests. 1929.

Latviešu personu vārdu un uzvārdu studijas. I. Vecākie personu vārdi un uzvārdi (XIII-XVI g.s.). Rīga: Ģ̣enerālkomisijā pie A. Gulbja.

Dunsdorfs, Edgars (izd.). 1938-1941.

Vidzemes 1638. gada arklu revīzija. 4 burtnīcas. Rīga: Latvijas vēstures institūta apgādiens. (Latvijas vēstures avoti. 4. sēj.) (atsauce E. Dunsdorfa ievada tekstam)

Frīdenberga, Anna. 2014. Deminutīvi Georga Manceḷa darbos. Vārds un tā pêtī̌šanas aspekti 18. Liepāja: LiePA, 74-87.

$\mathrm{HdV}=$

Jansone, Ilga. 2015.

$\mathrm{LVVV}=$

Seibicke, Wilfried. 1996-2007. Historisches deutsches Vornamenbuch. 5 Bde. Berlin, New York: Walter de Gruyter.

Priekšvārdu dinamika Ērğemes evangẹeliski luteriskajā draudzē 18. gadsimtā. Onomastica Lettica 4. Rīga: LU Latviešu valodas institūts, 252-288.

Andronova, Everita; Frīdenberga, Anna; Siliņa-Piņķe, Renāte; Trumpa, Anta; Vanags, Pēteris. Latviešu valodàs vēsturiskā vārdnīca (16.-17. gadsimts). Pieejama: https://tezaurs.lv/lvvv/ (skatīta 24.08.2020.)

Mancelius, Georg. 1638. Lettus, Das ist Wortbuch / Samt angehengtem täglichem Gebrauch der Lettischen Sprache; Allen vnd jeden Außheimischen / die in Churland / Semgallen vnd Lettischem Liefflande bleiben / vnd fich redlich nehren wollen / zu Nutze verfertigt / Durch Georgivm Mancelivm Semgall. der H. Schrifft Licentiatum \&c. Gedruckt vnnd verlegt zu Riga / durch GERHARD. Schröder / Anno M. DC. XXXVIII.

Ragauskaitė, Alma. 2019. Joniškiečių vyrų asmenvardžių darybos tendencijos seniausioje Lietuvoje 1599-1621 m. Joniškio krikšto metrikų knygoje. Acta Linguistica Lithuanica LXXX. Vilnius: Lietuvių kalbos institutas, 177-194.

Siliņa-Piṇkge, Renāte. 2016. Von Hindrik zu Indulis: mittelniederdeutsche Spuren in heutigen lettischen Vornamen. Hough, Carole; Izdebska, Daria (eds.) Names and Their Environment. Proceedings of the 25th International Congress of Onomastic Sciences, Glasgow, 15-19 August 2014. vol. 3. Glasgow: University of Glasgow, 233-246. 
Siliņa-Piņķe, Renāte. 2014a. Izplatītākie zemnieku vārdi Vidzemē 17. gadsimta pirmajā pusē. Baltistica XLIX(1). Vilnius: Vilniaus universitetas, 177-196.

Siliņa-Piņķe, Renāte. 2014b. Personvārdi 1638. gada zviedru arklu revīzijā: analīzes problēmas un risinājumi. Onomastikas pētìjumi / Onomastic Investigations. Vallijas Dambes 100. dzimšanas dienai veltītās konferences materiāli / Proceedings of the International Scientific Conference to commemorate the 100th anniversary of Vallija Dambe. Rīga: LU Latviešu valodas institūts, 198-212.

Siliņa-Piņķe, Renāte. 2013. Antroponīmikas terminolog̣ijas problēmas un latviešu personvārdu vēsture. Vārds un tā pêtī̌šanas aspekti 17.1. Liepāja: LiePA, 216-226.

Siliņa-Piņķe, Renāte. 2005. Jahn, Jane, Jahne: zemnieku vārdu rakstība 1638. gada zviedru arklu revīzijā Vidzemē. Baltu filoloğija XIV (1) 2005. Rīga: LU Akadēmiskais apgāds, 143-151.

Siliņš, Klāvs. 1990.

Latviešu personvārdu vārdnīca. Rīga: Zinātne.

Sinkevičiūtè, Daiva. 2006.

Lietuvių dvikamieniu asmenvardžiu trumpiniai ir jų kilmes pavardes. Vilnius: Vilniaus universiteto leidykla.

Stender, Gotthard Friedrich. Lettisches Lexikon In zween Theilen abgefasset, und den Liebhabern 1789 . der lettischen Litteratur gewidmet. Mitau: Steffenhagen.

Ulmann, Carl Christian. Lettisches Wörterbuch. Erster Theil. Lettisch=deutsches Wörter1872. buch. Riga: H. Brutzer \& Co.

Ulmann, Carl Christian; Lettisches Wörterbuch. Zweiter Theil. Deutsch=lettisches WörterBrasche, Guftav. 1880. buch. Riga, Leipzig: H. Brutzer \& Co.

VAR $=$ Dunsdorfs Edgars (izd.). 1938-1941. Vidzemes 1638. gada arklu revīzija. 4 burtnīcas. Rīga: Latvijas vēstures institūta apgādiens. (Latvijas vēstures avoti. 4. sēj.) (atsauce revīzijas tekstam)

Vulāne, Anna. 2013. Vārddarināšana. Auziņa, Ilze u. c. Latviešu valodas gramatika. Rīga: LU Latviešu valodas institūts, 190-299.

Renāte Silina-Piṇke, Latvijas Universitātes Latviešu valodas institūts Akadēmijas laukums 1 LV-1050, Rìga, Latvija rsp@edu.lu.lv

\section{SUMMARY}

\section{Latvian Personal Names with -it and -ull in 17th Century Sources}

\section{Renāte SILIN̦A-PIN̦K,E}

This paper analyzes the functions of the suffixes -it and -ull in Latvian anthroponyms recorded in the 17th century. Among the 825 forms of Latvian names fixed in the protocols of the 1638 land revision in Swedish Livonia, 16 names had these suffixes (carried by 25 persons out of 12,150). 10 names (of 13 persons) have the suffixes -it(t), -its, -itz, and 6 names (of 12 persons) have the suffixes - ull or $-u l s$. 
Names containing the suffix -ull in this revision are as follows: Andull (5), Jackull (1), Janull (1), Mattuls (1), Michuls (1) and Mickull (3). In the dictionary "Lettus" (1638) by Georg Mancelius, the only personal name with suffix -ul-is Berrtulis. In the 1638 revision, this name appears in its German form Bertel. In the dictionary "Lettisches Lexikon" (1789) there are more names of this type: female names Audule, Bahrbule and male names Behrtuls, Induls, Pahwuls and Sahmuls. The absence of Andulis in 17th and 18th century dictionaries can possibly be explained by the fact that its area of distribution was limited to southeastern Vidzeme, the area of the Selonian sub-dialects.

10 word forms ending with -it(t), -its and -itz are derived from six personal names: Brencis, Ansis, Jānis, Josts, Juris and Laurs. Seven of 13 persons are children below the age of seven. These derived names cannot be found in the dictionaries of the time. It suggests that the suffix $-\bar{i} t$ - might have been used for derivations from already existing Latvianized names, and that it mainly had the diminutive function already in those times.

Since the usage of these suffixes turned out to be rather diverse and varied, it was not possible to identify general tendencies. Unfortunately, due to the shortage of personal name recordings of good quality, most of the conclusions made as the result of this study are in the form of hypotheses only. 


\title{
BLËDIS, BLËDĪGS, BLEEDNIEKS UN LIEKULIS LATVIEŠU VALODAS SENAJOS TEKSTOS: NOZİMES PĀRMAIṆA?
}

\author{
Anta TRUMPA \\ Latvijas Universitāte
}

\section{Ievads}

Raksts ir kā turpinājums pētījumam, kas veltīts trīs 17. gadsimtā nepārprotami negatīvas īpašības izsakošu substantīvu - blēdība, valšksība, pārgalvī$b a-$ no mūsdienām semantiski atšksirīgajam lietojumam Ernsta Glika Jaunās Derības tulkojumā (1685) un tā analīzei. Turpinot negatīvas konotācijas vārdu nozīmiju attīstības pētniecību, šajā rakstā tiks analizēta vārda blēdis un tā atvasinājumu - blēdīgs un blēdnieks - semantika 17. gadsimta tekstos ${ }^{1}$, nedaudz aplūkojot arī vārda liekulis lietojumu. Vārds liekulis 16. gadsimta rakstos nav minēts vispār, taču 17. gadsimtā nereti tas traktēts kā vārda blēdnieks sinonīms, tādējādi šo vārdu lietojums ir aplūkojams kopā.

Šì raksta mērḳis ir analizēt vārdu blēdis, blēē̄gs, blēdnieks un liekulis minējumus 17. gadsimta tekstos, salīdzinot tos ar mūsdienu lietojumu, mēgeināt noteikt, vai tas ir atškirīigs, proti, vai ir notikusi nozīmes pārmaiņa, un kādi varētu būt šāda atšksirīga lietojuma iemesli.

Tā kā 17. gadsimta teksti pamatā ir relig̣iskie teksti, no kuriem daḷa (Bībele) tiek jaunos tulkojumos un jaunās redakcijās izdota vēl līdz šim, tad salīdzināšana ar šiem jaunajiem tulkojumiem ir ja ne precīzākā, tad ātrākā metode, kā noteikt semantisko atškirī̄bu starp agrāko lietojumu un mūsdienām. Precizēt vārdu semantiku un noteikt to iespējamo semantisko pārmaiņu var, salīdzinot konkrētā vārda lietojumu latviešu senajos tekstos ar attiecīgo vietu orig̣inālajā darbā un, ja nepieciešams, meklējot šo vārdu nozīmes skaidrojumus dažādu gadsimtu tulkojošās vārdnīcās.

Salīdzinot E. Glika latviešu Bībeles tulkojumu (1685-1694) un Bībeles tulkojuma 1965. gada revīziju, ir vērojama uzkrītoša disproporcija starp vārdu blēdis un tā atvasinājumu lietojumu 20. gadsimta vidus Bībeles tekstā un nedaudz mazāk nekā 300 gadus senākajā tekstā - pirmajā Bībeles tulkojumā latviešu valodā. Bībeles 1965. gada revīzijas elektroniskajā variantā vietnē www.bibele.lv visās Bībeles grāmatās kopā ir fiksēti tikai 14 gadījumi (8 Vecajā Derībā un 4 Jaunajā Derībā), kad ir minēta sakne blêd- vai blē̌ž-, piemēram,

1 Šis pētījums balstās uz Latviešu valodas seno tekstu korpusa (http://senie.korpuss.lv/), kurš aptver arī 16. gadsimta avotus, taču pētāmie vārdi šì gadsimta avotos vēl nav sastopami. 
Neprašu vairs nesauks par dižciltīgu un blēdi par cienījamu cilvēku (Bībele 1965, Jes 32: 5) - vārds blēdis 4 reizes, vārds blēdība 9 reizes, vārds blēdīgs tikai 1 reizi, vārds blēdnieks nav minēts vispār. Turpretī E. Glika tulkojumā 17. gs. beigās ir 121 šīs saknes vārdu lietojuma gadījums (99 Vecajā Derībā, 22 Jaunajā Derībā) - vārds blēdis 11 reižu, vārds blēdība 74 reizes, vārds blēelīgs 24 reizes, vārds blēdnieks 14 reižu. Šie skaitlai uzreiz pievērš uzmanību faktam, ka vārdi blèdis, blēdnieks, blèdība $a^{2}$ un blèdīgs 17. gadsimta tekstos ir bijuši ar plašāku un intensīvāku lietojumu nekā 20. un 21. gadsimtā. Rodas jautājums, kas tad ir nācis šo vārdu vietā un vai vārdi ar sakni blēd-Glika Bībelē nav lietoti ar citu nozīmi nekā mūsdienās.

Blēdnieks un blēē̄gs, visticamāk, ir atvasināti no vārda blēdis. Par šī vārda etimolog̣iju pētnieku domas dalās. Konstantīns Karulis uzskatīia, ka tā pamatā ir indoeiropiešu sakne *mel- '(sa)grūst, (sa)berzt, sist, malt' ar nozīmes pārmaiņu 'malt' $\rightarrow$ 'runāt niekus, melst' $\rightarrow$ 'mānīt' (Karulis 1992 I 134). Ticamāks tomēr šķiet Jāņa Endzelīna viedoklis, proti, zinātnieks uzskatīja, ka vārds aizgūts no senkrievu блядь 'krāpnieks' (ME I 314). Arī lietuviešu blèdis 'ḷaunums, zaudējums, nelaime', blèdingas 'kaitīgs' (LKŽ I 896) tiek saistīts ar senkrievu *bljadb un baltkrievu bljadb 'krāpšana, krāpnieks' (Fraenkel LEW 48). Par lietuviešu blếdis un latviešu blēdis kā nepārprotamiem slāvismiem izteicies arī lietuviešu valodnieks Vincs Urbutis (1995: 12).

Pieņemot J. Endzelīna, E. Frenkela un daudzu citu etimologu viedokli par aizguvumu no slāvu valodām, varētu secināt, ka latviešu valodā šìs saknes vārdi kopš aizgūšanas faktiski nav mainījuši savas nozīmes, jo arī mūsdienās blēdis nozīmē 'cilvēks, kas savtīgos nolūkos rīkojas negodīgi, izmanto melus, krāpšanos, mānīšanos; cilvēks, kas ar viltību, mānīšanos izdara kādu nerātnību' (MLVV), blēdīgs nozīmēe 'tāds, kas savtīgos nolūkos rīkojas negodīgi, melo, krāpj, mānās; tāds, kurā izpaužas negodīgums, krāpšana, mān̄̄šanās; tāds, kas raksturīgs blēdim; škịelmīgs, viltīgs, nerātns', blēdnieks literārajā valodā lietots netiek, bet izloksnēs, piemēram, Kalupes izloksnē, pazīstams ar tādu pašu nozīmi kā blēdis: b'l'ied'n' iks tys, kas pazùk kù i apmalòi, apmùona (KIV I 180).

Tomēr latviešu valodas senajos tekstos paveras nedaudz cita aina, proti, vārds blēdis ir lietots ar plašāku semantiku nekā mūsdienās, savukārt atvasinājumiem piemīt vēl cita katram sava nozīmes nianse.

2 Vārds blēdība ir sastopams jau 16. gadsimta beigās, bet šajā rakstā analizēts netiks, jo tā semantika tika aplūkota jau raksta sākumā minētajā publikācijā (Trumpa 2019). 


\section{Blēdis}

\subsection{Vārda blêdis lietojums religíiskajos tekstos.}

Vārds blēdis ${ }^{3}$ ir latviešu valodas senajos tekstos jau kopš 17. gs. sākuma lietots vārds, tiesa, mazāk izplatīts par tā atvasinājumiem.

Vārds lietots līdzīgā kontekstā kā mūsdienās, attiecinot to uz personu, kam piemīt nenoliedzami negatīvas īpašības, piemēram, šajā Georga Manceḷa sprediķu grāmatas teikumā: Buhß dafcham Blehfcham Bleñas runnaht / fawu Tuwaku neewaht / apmähloht / jaunas Wehftes neft (Manc1654_LP2, 217 19 ). Tomēr, salīdzinot Bībeles vai cita garīga teksta tulkojumu ar oriǵinālu vai ar mūsdienu tulkojumu, nereti atklājas, ka 17. gadsimta lietojumā ir atšksirības.

Tajās Bībeles teksta vietās, kur 17. gadsimtā, sākot no 1615. gada psalmu tulkojuma un beidzot ar gadsimta beigu E. Glika Vecās Derības tulkojumu, lietots vārds blēdis, tekstu orig̣inālā un mūsdienu tulkojumā atbilst virkne vārdu ar vairāk vai mazāk atšksirīgām plaša spektra negatīvām nozīmēm, proti, ne tikai 'blēdis', bet arī 'nelietis', 'noziedznieks', 'ḷaundaris', 'ḷaunais', 'pretinieks', 'zaimotājs', 'viltusvērpējs'.

\subsection{1. 'Nelietis'}

Ar nozīmi 'nelietis' vārds blēdis lietots jau kopš pašiem pirmajiem vārda minējumiem 1615. gadā līdz pat Vecās Derības tulkojumam 17. gadsimta beigās. 1615. gada psalmos latviešu teksts skan: Kur precks vnde mers ar pargalwibe / Gir lounems vnde bledems (Ps1615, 157 22), salīdzinājumam 1559. gada lejasvācu oriǵinālā attiecīgajai vietai atbilst teksts: Dar freudt vnd frede im fufe ftedt/ I hebben böfen vnd böuen (Vanags 2000: 116). Lejasvācu bove, Bube tiek tulkots kā 'nelietis, noziedznieks' (Schiller-Lübben I 408-409). Mūsdienu Bībelē šì vieta tulkota: Ir nelietis, sērīgi salīcis, bet iekšpusē viltus pilns.. (Bībele 2012: 1944). Nozīme 'nelietis' vārdam blēdis lietota arī E. Glika Vecās Derības tulkojumā: Tad nu isdohdeet tohs Wihrus/ tohs Blehfchus/ kas eekfch Gibejas irr.. (VD1689_94, Sog, 20:13). Un mūsdienās: Izdodiet tos Gibas vīrus, neliešus.. (Bībele 2012: 440).

Mūsdienās vārdu blēdis un nelietis nozīmes ir tuvas, tomēr tās nav identiskas, vārds nelietis apzīmē vispārīgu negatīvu kādas personas raksturojumu, kamēr vārda blēdis semantika ir konkrētāka - 'viltnieks, krāpnieks'.

\subsection{2. 'Pretinieks', 'zaimotājs'}

Semantiska atšksirība salīdzinājumā ar mūsdienām vērojama arī tādos vārda blēdis 17. gadsimta lietojumos, kuriem mūsdienu latviešu Bībeles

3 Atšksirībā no mūsdienām vārds lietots tikai vīriešu dzimtes formā. 
tulkojumos atbilst vārdi pretinieks un zaimotājs. 17. gadsimta tekstos katrs no šiem gadījumiem sastopams vienu reizi - abos gadījumos divos dažādos Sīraha grāmatas tulkojumos: Kad Beßdeewiex Blehdi lahd / tad tas föw paffcham lahd (Manc1631_Syr, 5555). Mūsdienās šajā vietā: Apkraudams pretinieku ar lāstiem, bezdievīgais nolād pats sevi (Bībele 2012: 1948). Interesanti, ka Mārtiņa Lutera 1545. gada Bībeles tulkojumā šajā vietā ir lietots vārds Schalk 'viltnieks, blēdis', kas varētu liecināt par to, ka šajā gadījumā latviešu blēdis tomēr ir lietots ar nozīmi 'viltnieks' un attiecīgais teksts tulkots nevis no oriǵināla, bet no vāciskā tulkojuma: WEnn der Gottlos einem schalck flucht / So flucht er jm selber. (Luth.1545, Syr, 21: 30)

Vēl viens piemērs: Kas fawu Tehwu atftahj/ tas kluhft par Blehdi turrehts/ in kas fawu Mahti apbehdina/ tas irr nolahdehts no ta Kunga (VLH1685_Syr, $4 \mathrm{~B}_{15}$ ), un mūsdienu tulkojumā: Kas pamet nelaimē tềvu - ir kā zaimotājs, kas sanikno māti - Kunga nolādēts (Bībele 2012: 1912). Jāatzīmē, ka Manceḷa 1631. gada šīs pašas Vecās Derības grāmatas tulkojums šajā vietā ir tuvāks mūsdienu tulkojumam nekā 1685. gada teksts: Kas fawu Tähwu attftay / tas kluhft faymohtz / vnd kas fawu Maht apbähdina / tas gir nolahdätz no Kungu (Manc1631_Syr, 5218), kas apliecina to, ka vārdi blēdis un zaimotājs 17. gadsimtā atškịirībā no mūsdienām tiešām tika uztverti kā sinonīmi.

\subsection{3. 'Ļaundaris', 'launais'}

Visbiežāk vārdam blēdis seno tekstu lietojumā mūsdienu Bībeles tulkojumā atbilst vārds lạ laundaris vai launais, proti, izteikti negatīvs kādas personas apzīmējums, un var teikt, ka ļaunuma sēma ir tā, kas atšķir senos vārda blēdis lietojumus no mūsdienām. Aplūkojot piemērus, kuros vārda blēdis lietojumam senajos tekstos oriǵinālā un mūsdienu tulkojumā atbilst vārds ar nozīmi 'ḷaundaris', atsevišş̧os gadījumos šì nozīme var tikt izsecināta arī pēc konteksta, piemēram, Mateja evaņ̧ểiijā minētajā pretstatā 'labais' un 'ḷaunais': Bet tas Lauks irr ta Pafaule: Un ta labba Sehkla irr tee Behrni thas Walftibas: Un ta nikna Sahle irr tee Behrni tha Blehfcha (JT1685, Mt, 13:38). Mūsdienu Bībeles tulkojumā šī vieta skan: ..nezāles ir lạunā dēli (Bībele 2012: 2168).

Tomēr pārsvarā gadījumu arī šì nozīme ir izsecināma, tikai salīdzinot 17. gadsimta tekstu ar orig̣inālu un vēlākiem tulkojumiem latviešu valodā. Piemēram, 2. Samuēla grāmatā esošajā piemērā pēc konteksta varētu saprast, ka runa ir par blēdīgu, negodīgu cilvēku, nevis gluži par ḷaundari: tu effi krittis/ ittin kà kas preekfch netikleem Blehfcheem kriht (VD1689_94, 2Sam, 3:34). Turpretī mūsdienu tulkojumā teksts: $k \bar{a}$ no laundara rokas tu esi kritis (Bībele 2012: 513) atbilst senebreju oriğinālā esošajam tekstam, kura burtiskais tulkojums latviski ir 'netaisnības (nekrietnības, lạunuma) dēli' (GH). 


\subsection{4. 'Viltvārdis', 'viltusvērpējs'}

Lietojums ar nozīmi 'vilttvārdis' vai 'viltusvērpējs' ir sastopams tikai vienā Bībeles tulkojuma vietā: Kaß föw paffcham Ghräku darra / taß tohp pareife nofauktz Blehtz par wiffeem Blehfcheem (Manc1637_Sal, 78 21 ), mūsdienās: Kas gudro uz launu, tam vārdā-viltusvērpējs (Bībele 2012: 1100). Tiesa, Mārtiņa Lutera 1545. gada vāciskajā Bībeles tulkojumā šajā teksta vietā lietots vācu Ertzbösewicht 'ḷauns cilvēks, nelietis': Wer jm selbs schaden thut / Den heisst man billich einen Ertzbösewicht (Luth.1545, Sal, 24: 8). Ja Georgs Mancelis tulkojot ir izmantojis nevis oriǵinālu, bet Lutera vācisko tulkojumu, tad var pieḷaut arī iespēju, ka blēdis 1637. gada tulkojumā lietots ar nozīmi 'nelietis'.

\subsection{Vārda blēdis lietojums 17. gs. vārdnīcās}

Relig̣iskajos tekstos sastopamās vārda blēdis nozīmes apstiprina arī 17. gadsimta vārdnīcas, tiesa, šeit izteiktāk nekā relig̣iskajos tekstos redzama mūsdienu nozīme 'viltnieks, krāpnieks': G. Manceḷa vārdnīcā ar vārdu Blehdis tulkoti vācu vārdi Bößwicht/ Bube [ḷaundaris, nelietis] (Manc1638_L, 39A $\mathrm{A}_{12}$ ), Lecker/Schalck [kārumnieks, viltnieks] (Manc1638_L, 114B 2 ), minēts arī vārdu savienojums Ein alter Schalck, kas tulkots kā wätz Blehdis [vecais viltnieks] (Manc1638_L, 19B 9 ). Līdzīgi vārds skaidrots arī Fīrekera vārdnīcas manuskriptos: Blehdis, Ein loser bube [nelietis] (Fuer1650_70_1ms, 44 19). Nozīme 'nelietis' šajos manuskriptos redzama arī vārda blēdis lietojumam kontekstā, piemēram, 1. manuskriptā: Kà blehdis tu dsihwo, kà blehfam tew arri weddahs. bübisch [nekrietni, nelietīgi] lebestu, bübisch gehet dirs auch (Fuer1650_70_1ms, 44 20).

K. Fīrekera vārdnīcā ir minēts arī maz zināms saliktenis ar neskaidru nozīmi sprākblēdis: Germ. Mahrskalkis. Ein Maar schall. dsihres Usraugs. recte, ironicè vero dicitur\{d[icitu\}r.\}. Sprahk=Blehdis (Fuer1650_70_1ms, 1563) ${ }^{4}$, kura semantiku īsti nespēj atklāt ne vāciskais tulkojums Ein Maar schall [maršals], ne divi blakus minētie sinonīmi Mahrskalkis un dsihres Usraugs. Iespējams, šo apzīmējumu semantika ir atrodama „Vainižu izloksnes vārdnīcā“", kurā vārds mãršâls skaidrots kā 'jauneklis, vīrietis, kas pavada jauno pāri laulībās' (Ādamsons, Kagaine 2000 I 505). Iespējams, sprākblēdis ir kāzu ieražu personāžs, kura nosaukums, kā novērojis K. Fīrekers, ir lietots ironiski.

J. Langija vārdnīcas manuskriptā vārdi Blähdis un Blähdneeks ir doti kā sinonīmi ar tulkojumu ein Bube, Schalck, Heuchler [nelietis, viltnieks, liekulis] (Langijs 1936: 34). Tiesa, reliǵiskajos tekstos vārds blēdis ar nozīmi 'liekulis, liškis' īsti nav sastopams. Te vēl jāpiemin novērojums, ka 17. gs. vārdnīcās

4 Salīdzinājumam anonīmajā 17. gadsimta vārdnīcas manuskriptā „Manuale...“ šajā pašā kontekstā ir minēts vārdu savienojums sprākles blēdis: Sprahkles Blehdis (MLG 103). 
blēdis un blēdnieks ir sniegti kā sinonīmi, bet tekstos tomēr ir redzama nozīmes diferencēšanās.

Rezumējot par vārda blēdis lietojumiem latviešu valodas senajos tekstos, var teikt, ka tā nozīme nenoliedzami ir bijusi plašāka un emocionāli ekspresīvāka nekā mūsdienās, ar šo vārdu apzīmēti cilvēki ar plaša spektra negatīvām īpašībām: 'viltnieks', 'nelietis', 'ḷaundaris', 'zaimotāis', turklāt reliğiskajos tekstos dominē mūsdienām svešāka nozīme 'lạundaris, nelietis', turpretī vārdnīcās pamatā vārdam minētas abas šîs nozīmes: 'nelietis, ḷaundaris' un mūsdienām atbilstošā 'viltnieks'.

\section{Blēdīgs}

\subsection{Vārda blēdīgs lietojums religiskajos tekstos}

Līdzīga semantika 16., 17. gs. tekstos ir arī īpašības vārdam blēdīgs, kas, visticamāk, ir atvasināts no vārda blēdis. Salīdzinot senos lietojumus Bībeles tekstos ar mūsdienu tulkojumiem, redzama samērā liela daudzveidība: Blehdiga Sirds (VLH1685_Sal, 27A A $_{1}$ - greiza sirds (Bībele 2012: 1089); Blehdiga Mehle (VLH1685_Sal, 40A 13 ) - melu mēle (Bībele 2012: 1105); blehdiga Draudfe (VD1689_94, Jer, 9:2) - krāpnieku pulks (Bībele 2012: 1310); blehdigahm Wallodahm (VD1689_94, Sak, 17:4 ) - posta runās (Bībele 2012: 1089); blehdigeem Zelleem (VD1689_94, Ps, 119:101) - launas takas (Bībele 2012: 1036); blehdigi Laaudis (VD1689_94, Sog, 19:22) - nelieši (Bībele 2012: 439), blehdigs Kalps (JT1685, Lk, 19:22) - nelietīgais kalps (Bībele 2012: 2302), blehdigs un kuhtrs Kalps (JT1685, Mt, 25:26) - nelietīgais un slinkais kalps (Bībele 2012: 2195), blehdigs Leezineeks (VD1689_94, 5Moz, 19:16) - launs liecinieks (Bībele 2012: 329).

Tāpat kā vārda blèdis gadījumā 17. gadsimta tekstos vārdam blēdīgs sastopamas ne tikai mūsdienām atbilstošās nozīmes 'viltīgs, negodīgs, krāpniecisks', bet arī 'ḷauns un nelietīgs', tāpat arī citas negatīvas īpašỉbas izsakošas nozīmes, piemēram, 'nodevīgs'. Arī pašā senākajā latviešu tekstos fiksētajā vārda blēdīgs lietojumā 1615. gada psalmu tulkojumā vārds acīmredzot minēts ar nozīmi 'nodevīgs': Aifto newens töp kounän kas töuwes gaide / beth kounan bus thems tapt / tems bledigems polgetayems (Ps1615, 42 10 ), salīdzinājumam 2012. gada Bībeles tulkojumā šajā vietā: ..liec tos kaunā, kas steidzas nodot! (Bībele 2012: 922). Tas saskan arī ar origínālo tekstu senebreju valodā, kas burtiskā tulkojumā skan: tos, kas ir nodevīgi tukšām rokām (GH).

Īpaši izceḷams īpašības vārdu substantivējums tas blēè̄gais, kuram atbilstošajās vietās mūsdienās ir šādi tulkojumi - llaunais, nelietis, netaisnais, laundaris, piemēram: Tas Blehdigajs ne buhs nenofeedfigs (VD1689_94, 
Sak, 11:21), mūsdienās: ..launais neizbēgs soda.. (Bībele 2012: 1080), Kurra Azzîs tee Blehdigee nizzinati (VD1689_94, Ps, 15:4), mūsdienās: kas neieredz neliešus ne acu galā.. (Bībele 2012: 910), Kurffch pahrftahwehs manni prett teem Blehdigeem? (VD1689_94, Ps, 94:16), mūsdienās: Kas celsies par mani pret netaisnajiem? (Bībele 2012: 1004), Tam Besdeewigam gribbahs to Blehdigo * Wiltiba (VD1689_94, Sak, 12:12), mūsdienās: Ļaundaris traucas laundaru tīklos.. (Bībele 2012: 1081).

Tāpat kā vārda blēdis gadījumā, ja nav iespējas salīdzināt ar oriǵinālu vai mūsdienu tulkojumu, arī šeit ne visur ir iespējams pēc konteksta noteikt precīzu nozīmi. Tā, piemēram, G. Manceḷa tekstā: ..Stundina nahk / weenu fchehlighu ghallu dohd / und ar fchälaftibu no fchahß blehdighas Paffaules py föw eekfchan Däbbäffu usjembs (Manc1654_LP1, 464 21 ) var, protams, izteikt minējumu, ka runa ir par lạunu pasauli, bet tomēr īsti skaidrs šis lietojums nav.

17. gadsimta tekstos, bet jo īpaši G. Manceḷa sprediķos, izplatīts ir vārdu savienojums blēeīga sirds, kas vairākkārt tiek minēts viltīgu cilvēku kontekstā, tādējādi rodoties iespaidam, ka šī vārdkopa varētu nozīmēt 'viltīga sirds', kaut gan mūsdienās šāds lietojums nav pierasts: Vs tahdeem willtighem Zillwäkeem / kattreem blehdigha Sirrds gir / bett miexta Mehle preekfch Deewu / rahda Deews patz ar Pirrxteem / fatzidams.. (Manc1654_LP1, 177 17).

Tomēr Sīraha grāmatas 1631. gada tulkojumā esošajam šì vārdu savienojuma piemēram: Blehdiga Sirds gir ka kahtz willams Puttnis wirffu jumtu Ahfchu ghalla / vñ gluhna / ka wings töw guhftiet warrehtu (Manc1631_Syr, 537 ${ }_{12}$ ) mūsdienu tulkojumā atbilst teksts: Kä vilinātāja irbe mednieka murdāaugstprātīgajam sirds (Bībele 2012: 1929).

Savukārt Sālamana pamācību 1685. gada tulkojumā lietotajam blēdīga sirds - Blehdiga Sirds neneeka labba ne atrohd.. (VLH1685_Sal, 27A 1 ) mūsdienu tulkojumā atbilst greiza sirds - Kam greiza sirds, tam neredzēt laba.. (Bībele 2012: 1089). Salīdzinājumam Mārtiņa Lutera 1545. gada Bībeles vāciskajā tulkojumā atbilstošā vieta tulkota līdzīgi kā mūsdienu latviešu valodā: Ein verkeret Hertz findet nichts guts (Luth.1545, Sal, 17:20), arī senebreju oriğināla burtiskais tulkojums ir: nepareiza sirds (GH). Starp citu, E. Glika Bībeles tulkojumā šajā vietā ir vārdi: Kam pahrwehrtita Sirds irr/ tas Labbumu ne atraddihs (VD1689_94, Sak, 17:20), un vārds pārvērtīts 17. gadsimta tekstos pamatā lietots ar nozīmi 'greizs'. Acīmredzot E. Gliks atradis oriğinālajam tekstam vairāk atbilstošu un precīzāku apzīmējumu. Šis piemērs vedina uz domām, ka 17. gadsimtā vārds blēdīgs daḷā gadījumu izmantots kā vispārināts negatīvas īpašības apzīmējums, nevarot atrast precīzāku. Savukārt vārdkopas blēdīga sirds semantika rāda to, ka pat viens un tas pats vārdu savienojums ar vārdu blēdīgs 17. gadsimta tekstos ir ticis lietots ar atškisīgām nozīmēm. 


\subsection{Vārda blēdīgs lietojums 17. gs. vārdnīcās}

G. Manceḷa vārdnīcā šis adjektīivs nav ietverts vispār, savukārt K. Fīrekera vārdnīcas manuskriptos Blehdigs tulkots ar daudznozīmīgo arglistig [viltīgs; launprātīgs] (Fuer1650_70_1ms, 44 23 , Fuer1650_70_2ms, 736). J. Langija 1685. gada vārdnīcas manuskriptā blähdigs tulkots kā leichtfertig, argliftig [vieglprātīgs, neapdomīgs; viltīgs; lạanprātīgs] (Langijs 1936). Langija vārdnīcas manuskriptā minētā nozīme 'vieglprātīgs, neapdomīgs' tomēr îsti neatspogulojas saistìtajos tekstos.

Rezumējot jāatzīst, arī vārda blēdīgs nozīme ir bijusi plašāka salīdzinājumā ar mūsdienām un tam piemitušas vairākas negatīvas īpašîbas izsakošas nozīmes: 'negodīgs, viltīgs, ḷauns; nelietīgs'.

\section{Blēenieks un liekulis}

\subsection{Vārda blēenieks lietojums 17. gs. vārdnīcās}

No iepriekšminētajiem šĩs saknes vārdiem semantikas ziñā atšksiras mūsdienu literārajā valodā vairs aktīvi nelietotais vārds blēenieks. Š̉is vārds nav ietverts G. Mancela vārdnīcā, savukārt tajos vārdnīcu manuskriptos, kuros vārds blēdnieks ir sastopams, proti, K. Fīrekera vārdnīcas manuskriptos un J. Langija vārdnīcas manuskriptā, tas traktēts kā vārda blēdis sinonīms: Blehdis, Ein loser bube, blehdneeks [nelietis] (Fuer1650_70_1ms, 44 19, Fuer1650_70_2ms, 732), Blähdis, (Blähdneeks) ein Bube, Schalck, Heuchler [nelietis, viltnieks, liekulis] (Langijs 1936: 34).

\subsection{Vārda blēdnieks lietojums religiskajos tekstos}

Tomēr 17. gadsimta relig̣iskajos tekstos vārdu blēdis un blēdnieks lietojums nav gluži identisks. Ja vārdam blēdis ir diezgan konkrētas (lai arī ne vienmēr viegli nošķiramas) nozīmes: 'krāpnieks, viltnieks' un 'ḷaundaris, nelietis', tad vārdam blēdnieks senajos tekstos, balstoties uz mūsdienu tulkojumiem, ir plašāks lietojums: 'krāpnieks', 'bezdievis', 'bezgodis', 'ļaunais', 'lišskis', 'liekulis'; reizēm 17. gadsimta tekstos publicētajam vārda blēdnieks lietojumam mūsdienu tulkojumā atbilst aprakstošs tulkojums, piemēram, neklaufigs Bledneeks (VD1689_94, 1Sam, 20:30) - samaitātās tiepīgās sievas dēls (Bībele 2012: 488); Woj tu warretu Beedribu turreht ar to Blehdneeku Krehfla? (VD1689_94, Ps, 94:20) - Vai biedrosies tu ar posta tiesu.. (Bībele 2012: 1004).

Lielā mūsdienu atbilsmju dažādība varētu liecināt par to, ka vārds 17. gadsimta reliğiskajos tekstos un jo īpaši E. Glika Bībeles tulkojumā ir bijis vispārināts nelieša apzīmējums, aptverot ne tikai viltību, bet arī virkni citu 
īpašību. Kā savā promocijas darbā atzinusi Anna Frīdenberga: „Samērā daudz senajos rakstos ir atvasinājumi, kuriem ir tieši ìpašības nesēja nozīme - šie darinājumi apzīmē personu, kurai raksturīga īpašība, kas ietverta pamatvārdā, piemēram, blēdnieks, svešinieks, viltnieks." (Frīdenberga 2016: 138) Tomēr seno tekstu piemēri rāda, ka ar vārddarināšanas palīdzību ir notikusi arī semantiska diferenciācija, lietojumam kḷūstot semantiski plašākām.

\subsection{1. 'Krāpnieks'}

Mūsdienu izpratnei tuvāka nozīme 'krāpnieks' ir redzama, piemēram, senākajā šì vārda lietojumā 1615. gada psalmu izdevumā, bet tas ir arī vienīgais šīs nozīmes fiksējums: Kunx mufe paglabbotais rouge vs mums / To bledeneke Enaidibe zenn no fchennes (Ps1615, 7716). Te salīdzinājumam 1548. gada oriǵināls lejasvācu valodā: ..des Lurers viendtfchop.. (Vanags 2000: 64). Sal. vlv. lur = lurer 'Laurer, heimtückischer Mensch [krāpnieks, blēdis]' (SL II 750). Interesanti, ka atbilstošajā psalmā 1587. gada izdevumā šì vieta skan: Ta Lawitaye Enaidibe czen no fchennes (UP1587, H2B 4 ). Vārds lavītājs te acīmredzot arī lietots ar nozīmi 'tāds, kam ir slepeni, negodīgi nolūki', sal. lavîties 'nach etw. für sich haschen, sich heimlich erstreben [ķ̧, slepeni dzīties pēc kaut kā]' (ME II 433).

\subsection{2. 'Lišķis', 'liekulis'}

Skaitliski visbiežāk vārds blēdnieks senajos tekstos lietots ar nozīmēm 'lišksis' un 'liekulis'. Balstoties uz seno tekstu korpusu, var teikt, ka, izņemot E. Glika Bībeles tulkojumu, kurā minējumi ir plašāki (tajā skaitā arī Vecās Derības grāmatās) $)^{5}$, šāds lietojums ir sastopams galvenokārt konkrētā Jaunās Derības tulkojuma fragmentā, un, proti, visiem labi zināmajā līdzībā par skabargu un balķi, piemēram, Manceḷa „Lettisch Vade mecum“: Tu blehdneex weltz papreekfch to Balgki no tawas Atz.. (Manc1631_LVM, 151 24), 1685. gada rokasgrāmatā: Tu Blehdneeks / (Walkfchķi /) welz papreekfchu to Balķi no tawas Azs.. (VLH1685, 61 10 ), bet Glika Jaunās Derības tulkojumā jau šajā vietā ir izmantots tas pats vārds kā mūsdienās: liekulis, tiesa, vārdi blēenieks un valšķis vēl ir sniegti piezīmē kā paskaidrojošie vārdi, sinonīmi: Tu Leekuli/ * welz papreekfchu to Balķi no tawas Azs.. * Walfchķi jeb Blehdneeks (JT1685, Lk, 6:42). Mūsdienu tulkojumā šajā vietā arī ir vārds liekulis: Liekuli, vispirms izņem balki no savas acs.. (Bībele 2012: 2265).

Pēteris Vanags 2014. gada 17. janvārī notikušajā seminārā „Latviešu raksti un raksti Latvijā 16. - 19. gadsimtā — pētniecības aktualitātes un problēmas“

5 Tiesa, kā jau minēts, nozīme 'liekulis' ir fiksēta arī seno tekstu korpusā neietvertajā J. Langija vārdnīcas manuskriptā. 
savā referātā „1685. gada Jaunās Derības pēcvārds. Valodnieciskās piezīmes“ stāstīja par 1685. gada Jaunās Derības pēcvārdu, tā saukto Anhang, kurā E. Gliks paskaidrojis vārda liekulis lietojumu Jaunajā Derībā, aizrādot, ka vārdi viltnieks un blēdnieks šî jēdziena apzīmēšanai nav tik piemēroti kā liekulis. Ar to arī skaidrojams fakts, kādēl vairākās Glika Jaunās Derības tulkojuma vietās vārds blēdnieks ir dots iekavās kā paskaidrojošais vārds aiz vārda liekulis, piemēram, Lūkasa evaņgéliijā: Waj jums Rakftu=Mahzitajeem/ un Warifëẹreem/ juhs Leekuli (Blehdneeki)/ jo juhs effaht it ka apmefti Kappi.. (T1685, Lk, 11:44).

Tomēr ir vietas E. Glika Bībeles tulkojumā (gan Jaunajā, gan Vecajā Derībā), kurās vārds blēdnieks ar nozīmi 'liekulis' ir lietots bez citu sinonīmu pieminēšanas. Piemēram, Vecās Derības teikumam: Tas Blehdneeks maita fawu Tuwaku zaur to Mutti/ bet zaur Sinnafchanu tohp tee Taifnee ispeftiti (VD1689_94, Sak, 11:9) mūsdienu tulkojumā atbilst: Ar muti lišksis izn̄̄dē tuvāko.. (Bībele 2012, 1079). Savukārt Jaunās Derības tekstam: Un* atfchkirs to/ un dohs tam Algu ar teem Blehdneekeem. Tur buhs Raudafchana un Sohbo=Trihzefchana (JT1685, Mt, 24:51) mūsdienās atbilst: ..un pārš̌ḳels viņu pušu un liks vinga dalı ar liekuliem.. (Bībele 2012: 2193).

Paradoksāli ir tas, ka E. Glika Bībeles tulkojums ir vārda blēdnieks ar nozīmi 'liekulis' izplatītāis, jo Bībelē vārds blēdnieks ar šo nozīmi ir lietots visplašāk, tajā pašā laikā tieši Jaunajā Derībā šo vārdu ir mēǵināts aizstāt ar vārdu liekulis, turklāt pēcvārdā īpaši šādu rīcību pamatojot. Iespējams, ka sākotnējā teksta tulkojumā šajās vietās bija minēts blèdnieks, bet rediĝejot tas aizstāts ar vārdu liekulis, vārdu blēdnieks atstājot iekavās.

Tā kā vienīgā 17. gs. vārdnīca, kurā vārdam blēdnieks ir fiksēta nozīme 'liekulis', ir 1685. gada Langija vārdnīcas manuskripts un arī vēlāko gadsimtu leksikogrāfiskie avoti vārdam blēdnieks nozīmi 'liekulis, lišksis' neuzrāda, gribētos domāt, ka blēdnieks ar šo nozīmi ir bijis tulkotāju jaundarinājums, tiem sākotnēji īsti neatrodot piemērotu vārdu attiecīgā jēdziena apzīmēšanai, un, visticamāk, šāda nozīme nav bijusi pazīstama 17. gadsimta latviešu runā. Arī atsevišksi citi vārda blēdnieks lietojumi (piemēram, jau minētās vietas no Vecās Derības, kurām mūsdienu tulkojumā atbilst specifiski aprakstoši teksti) liecina par to, ka Bībeles tekstu tulkotāii (gan G. Mancelis, gan G. Fīrekers, gan E. Gliks) šo vārdu izmantojuši gadījumos, kad bija grūtības atrast piemērotu apzīmējumu dažādiem atškisingiem negatīviem tēliem.

\subsection{Vārda liekulis lietojums 17. gs. religisiskajos tekstos un vārdnīcās}

Vārdu liekulis ar 1. nozīmi 'Heuchler [liekulis]' J. Endzelīns uzskata par atvasinājumu no latviešu liktiês (ME II 497), savukārt K. Karulis vārdu saista ar latviešu lieks (Karulis 1992 I 524). Interesanti, ka seno tekstu korpusā vārds 
liekulis redzams tikai K. Fīrekera vārdnīcas 2. manuskriptā ar atsauci uz Lūkasa evanğêeliju: Leekulis. ein Heuchler. Luc. 13, v. 15 (Fuer1650_70_2ms, 2052) un vairākās vietās Mateja, Marka un Lūkasa evaņgểlijos E. Glika Jaunās Derības tulkojumā, tomēr ne reizes nav lietots E. Glika Vecās Derības tulkojumā. Kā jau minēts, tajās vietās, kur mūsdienu tulkojumā ir liekulis, Vecajā Derībā lielākoties ir blēdnieks. Jau minētajā pētījumā P. Vanags bija atklājis, ka Jaunās Derības tulkojumos, kas publicēti pirms E. Glika tulkojuma, vārdam liekulis atbilst blēdnieks, valkšķis un viltenieks.

Vārds liekulis ir minēts arī seno tekstu korpusā neietvertajā J. Langija 1685. gada vārdnīcas manuskriptā: Leekuls. ein Heuchler (Langijs 1936: 137).

Jāatzīmē, ka ne Fīrekera un Langija vārdnīcas manuskriptos, ne E. Glika Jaunās Derības tulkojumā, ne arī jebkurā citā seno tekstu korpusā ietvertajā tekstā nav sastopami atvasinājumi no vārda liekulis, piemēram, liekulīgs, liekulība, kas bagātīgi izmantoti Bībeles mūsdienu tulkojumos. Līdz ar to, lai arī Bībles tulkojuma pēcvārdā E. Gliks vārdu liekulis min nevis kā jaunvārdu, bet kā veiksmīgāku, piemērotāku vārdu attiecīgā termina apzīmēšanai, tomēr rodas iespaids, ka šis vārds varēja būt vai nu līdz tam mazlietots un mazpazīstams vārds vai varbūt pat speciāli Bībeles tulkojuma vajadzībām darināts jaunvārds, kas izplatījies līdz ar Jaunās Derības tulkojumu. Vēl 18. gadsimta beigās, piemēram, Jākoba Langes vārdnīcā blakus vārdam Leekulis, ein Heuchler dots vārdu savienojums Leekula darbs, Heucheley (Lange 1777: 172) un nevis atvasinājums liekulība.

\section{Secinājumi}

1. Vārdu blēdis, blēdīgs un blèdnieks lietojums 17. gadsimtā salīdzinājumā ar mūsdienām ir bijis plašāks un ar vairāk negatīvu konotāciju. Vārdam blēdis blakus mūsdienās zināmajai nozīmei 'krāpnieks, viltnieks' izplatìtāka nozīme ir bijusi mūsdienās vairs nelietotā 'nelietis, laundaris'.

2. Arī vārdam blēeīgs dominējušas nozīmēm 'launs, nelietīgs' un 'viltīgs', tomēr tulkojumos nereti vārds lietots vēl plašāk, piemēram, ar nozīmēm 'greizs', 'nodevīgs', 'negodīgs', šķiet, tulkotājiem neatrodot precīzāku apzīmējumu Bībeles oriğinālajā tekstā nosauktajām negatīvajām īpašībām.

3. Lai arī 17. gadsimta vārdnīcās vārdi blēdis un blêdnieks ir rādīti kā sinonīmi, tomēr reliǵiskajos tekstos atvasinājumam ir redzama nozīmes diferenciācija, proti, tā lietojums ir bijis daudzveidīgāks - mūsdienu literārajā valodā vairs tikpat kā nelietotais vārds blēdnieks 17. gadsimtā ir bijis vispārināts nelieša apzīmējums, aptverot virkni negatīvu īpašību: 
'krāpnieks', 'bezdievis’, ‘bezgodis', 'ḷaunais', 'lišksis’, ‘liekulis’ u. c.; šķiet, arī vārds blēdnieks nereti lietots, neatrodot precīzāku apzīmējumu Bībeles oriǵinālajā tekstā lietotajiem jēdzieniem. 17. gadsimta latviešu tekstos visizplatītākā vārda blēdnieks nozīme 'liekulis' tikusi lietota tikai šajā gadsimtā un galvenokārt Bībeles tulkojumā - šādu lietojumu neapstiprina ne agrākie, ne arī vēlākie leksikogrāfiskie avoti, tādēḷ to varētu uzskatīt par specifisku tā laika Bībeles tekstu tulkojumiem raksturīgu, iespējams, tulkotāju ieviestu nozīmi.

4. Vārdu liekulis, lai izvairītos no neatbilstošas vārda blēdnieks lietošanas kā mazpazīstamu vārdu ieteicis un popularizējis vai, iespējams, pat kā jaunvārdu ieviesis E. Gliks.

\section{Literatūra un avoti}

Ādamsons, Eduards; Kagaine, Elga. 2000.

Bībele 1965 =

Bībele 2012 =

DRW =

Fraenkel LEW =

Frīdenberga, Anna. 2016.

Fuer1650_70_1ms =

$\mathrm{GH}=$

JT1685 =

Karulis, Konstantīns. 1992.

Lange, Jacob. 1977.

Langijs, Johans. 1936.
Vainižu izloksnes vārdnīca, I-II. Rīga: LU Latviešu valodas institūts.

1965. gada revidètais Bībeles teksts - www.bibele.lv. [skatīts 07.05.2020.]

Bībele. Rīga: Latvijas Bībeles biedrība, 2012.

Deutsches Rechtswörterbuch. rw-www.adw.uni-heidelberg.de/ drw-cgi/zeige. [skatīts 30.05.2020.]

Ernst Fraenkel. Litauisches etymologisches Wörterbuch, I-II. Heidelberg-Göttingen, 1962-1965.

Nominālā vārddarināšana Georga Mancel̦a darbos. Promocijas darbs filoloǵijas doktora grāda iegūšanai. Rīga: Latvijas Universitāte.

Christopher Fürecker. Lettisches und Teutsches Wörterbuch zusahmen geschrieben und mit Fleiß gesamelt von Christopher Fürecker. 1. manuskripts, atrodas LU Akadēmiskās bibliotēkas Rokrakstu un reto grāmatu nodạ̣ā. http://www.korpuss.lv/senie/static/ Fuer1650_70_1ms.html [skatīts 07.05.2020.]

Greek / Hebrew interlinear Bible software. https://www.scripture4all.org/ [skatīts 27.05.2020.]

Tas Jauns Testaments Muhsu Kunga Jesus Kristus.. Riga: Gedruckt durch Johann Georg Wilcken, 1685. http://www.korpuss.lv/ senie/source.jsp?codificator=JT1685 [skatîts 07.05.2020.]

Latviešu etimolog̣ijas vārdnīca, I-II. Rīga: Avots.

Vollständiges deutschlettisches und lettisschdeutsches Lexicon, nach den hauptdialecten in Lief = und Curland ausgefertigt. Mitau: J. Fr. Steffenhagen.

Nìcas un Bārtas mācītāja Jāna Langija 1685. gada latviski-vāciskā vārdnīca ar ìsu latviešu gramatiku. Pēc manuskripta fotokōpijas izdevis un ar apcerējumu par Langija dzīvi, rakstību un valodu papildināịis E. Blese. Rīga: Latvijas Ūniversitāte. 


$$
\begin{aligned}
& \mathrm{KIV}= \\
& \mathrm{LKŽ}=
\end{aligned}
$$$$
\text { Luth. } 1545=
$$$$
\text { LVVV }=
$$

Manc1631_LVM =

Manc1637_Sal =

Manc1638_L =

Manc1654_LP2 =

Manc1631_Syr =

$\mathrm{ME}=$

MLG =

Ps1615 =

Schiller-Lübben - Karl

Schiller; August Lübben.

UP1587 =

Urbutis, Vincas. 1995.

Vanags, Pēteris. 2000.

VD1689_94 =
Antoņina Reķēna. Kalupes izloksnes vārdnīca, I. A-M. Rīga: Latviešu valodas institūts, 1998.

Lietuvių kalbos žodynas, I-XX. Vilnius: "Mintis", "Mokslas", Lietuviu kalbos institutas, 1941-2002.

Lutherbibel 1545 Original-Text übersetzt von Dr. Martin Luther aus dem Textus Receptus. http://liederschatz.net/biblia/biblia2 [skatīts 28.05.2020.]

Everita Andronova; Anna Frīdenberga; Renāte Siliņa-Piņķe; Anta Trumpa; Pēteris Vanags. Latviešu valodas vēsturiskā vārdnīca. Rīga: LU Latviešu valodas institūts, 2016-2020. http://tezaurs.lv/lvvv-exp/ [skatīts 04.06.2020. ]

Lettisch Vade mecum. Gedruckt zu Riga durch vnd in Verlegung Gerhard Schröders, 1631. http://senie.korpuss.lv/source. jsp?codificator=Manc1631_LVM [skatīts 20.05.2020.]

Die Sprüche Salomonis.. Riga: Gedruckt durch vnd in verleg Gerhard Schrödern, 1637. http://senie.korpuss.lv/source. jsp?codificator=Manc1637_Sal [skatīts 20.05.2020.]

Georgius Mancelius. Lettus, Das ist Wortbuch.. Riga: Gedruckt .. durch Gerhard Schröder, 1638. http://www.korpuss.lv/senie/ static/Manc1638_L.html [skatìts 20.05.2016.]

Georgius Mancelius. Lang=gewünschte Lettische Postill.. Riga: Durch Gerhard Schrödern gedruckt und verlegt, 1654. http:// www.korpuss.lv/senie/static/Manc1654_LP2.html [skatīts 20.05.2020.]

Georgius Mancelius. Das Hauß=Zucht=und Lehrbuch Jesu Syrachs.. Riga: durch und in Verlegung Gerhard Schröders, 1631. http://www.korpuss.lv/senie/static/Manc1631_Syr.html [skatīts 20.05.2020.]

Kārlis Mīlenbahs. Latviešu valodas vārdnīca. Rediẹejejis, papildināiis, turpinājis J. Endzelīns, I-IV. Rīga: Kultūras fonds, 1923-1932.

Manuale Lettico-Germanicum. Manuskripts atrodas LU Akadēmiskās bibliotēkas Rokrakstu un reto grāmatu nodạā.

Psalmen und geistliche Lieder.. Riga: Nicolaus Mollin, 1615. http://senie.korpuss.lv/source.jsp?codificator=Ps1615 [skatîts 20.05.2020.]

Mittelniederdeutsches Wörterbuch, I-VI. Bremen, 1875-1881.

Vndeudsche Psalmen.. [Kēnigsberga: G. Osterbergers, 1587] [skatīts 20.05.2020.]

M. Miežinio žodyno leticizmai. Baltistica $X X X$ (1). Vilnius: Vilniaus universiteto leidykla, 5-28.

Luterāņu rokasgrāmatas avoti. Vecākā perioda (16. gs. - 17. gs. sākuma) latviešu teksti. Rīga: Mantojums; Stokholma: Memento, 2000.

Ta Swehta Grahmata Jeb Deewa Swehtais Wahrds.. Riga: Gedruckt bey Johann Georg Wilcken, 1689. http://senie.korpuss. lv/source.jsp?codificator=VD1689_94 [skatīts 20.05.2020.] 
VLH1685 =

VLH1685_Syr =
Vermehrtes Lettisches Hand=Buch.. Riga: Druckts und verlegts Jhro HochFürstl: Hoff=Buchdrucker George Radetzky, 1685. http://senie.korpuss.lv/source.jsp?codificator $=$ VLH1685 [skatīts 20.05.2020.]

Das Haus=, Zucht= vnd Lehrbuch Jesus Syrach.. Mitau: George Radetzky, 1685. http://senie.korpuss.lv/source. jsp?codificator=VLH1685_Syr [skatīts 20.05.2020.]

\author{
Anta Trumpa \\ Latvijas Universitātes \\ Latviešu valodas institūts \\ Akadēmijas laukums 1 \\ LV-1050, Rìga, Latvija \\ antat@latnet.lv
}

\title{
SUMMARY
}

\section{Blēdis, blēdigs, blēdnieks and liekulis in the Old Latvian Texts: A Change of Meaning?}

\section{Anta TRUMPA}

This paper discusses the words blèdis, blèdīgs, blèdnieks and liekulis as used in the 17th century Latvian texts, comparing them with modern usage and analysing the differences and possible reasons for their semantic shift. In the 17th century, the words blēdis, blèeigss and blēdnieks had a wider scope of usage and a more negative connotation. Besides the modern meaning of 'deceiver, liar', the word blèdis was then more often used as a synonym for 'villain, evil-doer'. Similarly, the dominant meanings of the adjective blèdigs were 'evil, vicious' besides 'cunning', while in some translations it had a wider usage and expressed the meanings of 'crooked', 'treacherous', 'dishonest'. It seems that the translator used the word blèdīgs because he could not find a more suitable equivalent for the word used in the original Bible text.

Even though the 17th century dictionaries treat the words blēdis and blèdnieks as synonyms, the derivation blèdnieks has a more differentiated and varied meaning in the religious texts. This word, which nowadays is hardly ever used in Standard Latvian anymore, in the 17 th century seems to have been a generic term for someone evil, comprising a wide range of negative qualities: 'deceiver', 'godless, non-believing person', 'shameless person', 'evil-doer', 'flatterer', 'hypocrite', etc. In this case, too, the interpreter seems to have chosen the word as the closest available (but not entirely appropriate) equivalent of the original word.

The most widespread meaning of blēdnieks in the 17th century Latvian texts - namely that of 'hypocrite' - dominates only in that century and mainly in the Bible translation. It has not been supported either by earlier or later lexicographical sources, thus it could be regarded as a specific meaning introduced by the translators of the Bible. The word liekulis 'hypocrite' as a more suitable replacement for blèdnieks was later suggested and promoted by the translator Ernst Glück (it was probably also coined by him). 


\section{IZDOŠANAS PRINCIPI}

\section{Izdevuma tematika}

Baltu filologiija (BF) publicē pētnieciskus darbus visās baltu valodniecības jomās. Tiek pieņemti arī raksti par citu tematiku, kas var interesēt baltistus. Gaidīti tiek arī pārskata raksti, kas aplūko pētniecības stāvokli noteiktās baltistikas nozarēs, recenzijas, apskati.

\section{Vērtēšana}

Visus rakstus, kas iesniegti publicēšanai, izvērtē anonīmi, un tiem jābūt sagatavotiem tā, lai autora identitāte nav atklāta ne tekstā, ne bibliogrāfiskajās norādēs. Manuskriptu lasa vismaz divi vērtētāij, kas iesaka to pieņemt vai noraidīt, savu lēmumu pamatojot.

\section{Valoda}

BF publicē rakstus latviešu, lietuviešu, angḷu un vācu valodā. Autoriem, kuriem raksta valoda nav dzimtā, jārūpējas, lai viņu manuskripti valodas ziņā būtu sakārtoti jau pirms to iesniegšanas. Pētnieciskajiem rakstiem ¡âpievieno kopsavilkums angḷu valodā (līdz 250 vārdiem), kas atspoguḷo satura būtību.

\section{Manuskripta forma}

Autori ir aicināti iesūtīt redakcijai manuskriptu elektroniski Word un Pdf formātā, izmantojot Palemonas šriftu. Titullapā jānorāda raksta nosaukums, autora pilns vārds un akadēmiskā piederība. Manuskripti ir jāraksta ar divu intervālu lielu atstarpi. Pēc iespējas jāvairās no norādēm parindēs. Tabulas, diagrammas un kartes iesūtāmas atsevišksos failos, tās numurējot un nosaucot. Pielikumi pievienojami manuskripta beigās. Atsaucēm uz pielikumiem jābūt tekstā, norādot to vēlamo izvietojumu. Valodu piemēri rakstāmi kursīviem burtiem, nepieciešamais tulkojums vai skaidrojumsvienpēdiņās (starp apvērstiem komatiem).

\section{Atsauces}

Atsaucēs tekstā minams autora/redaktora uzvārds, izdošanas gads un vajadzīgās lappuses numurs, piemēram, (Rudzīte 1964: 15). Ja ir atsauces uz vairāk nekā vienu tā paša autora publikāciju vienā gadā, aiz gada skaitḷa jāpievieno burti $a, b$ utt. Iekavās jābūt vai nu pilnai atsaucei, vai, ņemot vērā kontekstu, tikai gadam un lappusei. Literatūras sarakstā norādāmi tie darbi, uz kuriem autors ir atsaucies tekstā. Literatūras saraksts kārtojams 
alfabētā pēc autoru/redaktoru uzvārdiem, norādot pilnu bibliogrāfisko informāciju. Piemēri:

\section{Monogrāfija vai rakstu krājums:}

Rudzīte, Marta. 1964. Latviešu dialektologiija. Rīga: Latvijas Valsts izdevniecība.

Stang, Christian S. 1966. Vergleichende Grammatik der baltischen Sprachen. Oslo, etc.: Universitetsforlaget.

Bergmane, Anna, Aina Blinkena. 1986. Latviešu rakstības attīstìba. Latviešu literārās valodas vēstures pêtījumi. Rīga: Zinātne.

Ambrazas, Vytautas (ed.). 1997. Lithuanian Grammar. Vilnius: Baltos lankos.

Blinkena, Aina (red.). 1997. Savai valodai. Latvijas Zinātñu Akadēmijas Goda loceklim Rūdolfam Grabim veltìts piemingas kräjums. Rīga: Latvijas Zinātñu Akadēmijas Vēstis.

\section{Sējums sērijā:}

Schmalstieg, William R. 2000. The Historical Morphology of the Baltic Verb. Washington: Institute for the Study of Man. (Journal of Indo-European Studies. Monograph No. 37)

\section{Raksti žurnālos un rakstu krājumos:}

Lagzdiņa, Sarmīte. 1998. Adverbien, Präpositionen oder Halbpräpositionen? Linguistica Baltica 7, 151-166.

Rudzīte, Marta. 1997. Izloksne vietvārdos. Aina Blinkena (red.). Savai valodai. Latvijas Zinātñu Akadēmijas Goda loceklim Rūdolfam Grabim velt̄its pieminạas krājums. Rīga: Latvijas Zinātṇu Akadēmijas Vēstis, 247-259. 


\section{PUBLICATION POLICY}

\section{Subject matter}

Baltu filologija (BF) publishes research studies in all areas of Baltic linguistics. Papers on non-Baltic subjects of interest to Balticists may also be considered. Review articles (longer analytical essays or broad surveys of research in specific areas), book reviews and informative notes are also welcome.

\section{Evaluation}

All articles submitted for publication are reviewed anonymously and should be presented in such a way that the author's identity is not revealed either in the body of the manuscript nor in bibliographic references. Manuscripts are read by at least two evaluators, who recommend acceptance or rejection, giving specific reasons for their decision.

\section{Language}

BF publishes contributions in Latvian, Lithuanian, English and German. Authors whose language of contribution is non-native are encouraged to have their manuscript reviewed for language before submission. Each manuscript should be accompanied by an English abstract (max. 250 words), summarizing the conceptual content of the article.

\section{Manuscript format}

Contributors are requested to send the manuscript in Word and PDF versions using Palemonas font. The title page must contain the title and the author's name and affiliation. Manuscript texts should be doublespaced. Footnotes should be avoided unless absolutely necessary. Tables, diagrams and charts should appear in separate files at the end of the manuscript, numbered consecutively and titled. Reference must be made in the text and approximate position indicated. Language examples in the body of the text should be italicized and when necessary followed by the gloss, which is to be enclosed between single inverted commas.

\section{References}

References are cited in the text by giving the name of the author/editor, year of publication, and the page reference, e.g. (Rudzite 1964: 15). If more than one article by the same author from the same year is quoted, $a$, $b$, etc. should follow the year. The context determines whether all of 
the above information, or all minus the author's name, should be in parentheses. The reference section should include all works referred to in the text and these works only. They are to be listed in alphabetical order by author/editor, with complete bibliographical details. Examples:

\section{Monograph or edited collection:}

Rudzīte, Marta. 1964. Latviešu dialektologiija. Rīga: Latvijas Valsts izdevniecība.

Stang, Christian S. 1966. Vergleichende Grammatik der baltischen Sprachen. Oslo, etc.: Universitetsforlaget.

Bergmane, Anna, Aina Blinkena. 1986. Latviešu rakstības attīstība. Latviešu literārās valodas vēstures pētījumi. Rīga: Zinātne.

Ambrazas, Vytautas (ed.). 1997. Lithuanian Grammar. Vilnius: Baltos lankos.

Blinkena, Aina (red.). 1997. Savai valodai. Latvijas Zinātņu Akadēmijas Goda loceklim Rūdolfam Grabim veltīts pieminas krājums. Rīga: Latvijas Zinātņu Akadēmijas Vēstis.

\section{Volume in a series:}

Schmalstieg, William R. 2000. The Historical Morphology of the Baltic Verb. Washington: Institute for the Study of Man. (Journal of Indo-European Studies. Monograph No. 37)

\section{Articles in journals and collections:}

Lagzdiņa, Sarmīte. 1998. Adverbien, Präpositionen oder Halbpräpositionen? Linguistica Baltica 7, 151-166.

Rudzīte, Marta. 1997. Izloksne vietvārdos. Aina Blinkena (red.). Savai valodai. Latvijas Zinātñu Akadēmijas Goda loceklim Rūdolfam Grabim veltīts piemiṇas krājums. Rīga: Latvijas Zinātṇu Akadēmijas Vēstis, 247-259. 

BALTU FILOLOGIJA

XXIX (1) 2020

Baltu valodniecības žurnāls

Redaktors Pēteris Vanags

LU Akadēmiskais apgāds

Tālr. 67034889

www.apgads.lu.lv

Iespiests SIA „Drukātava“ 